\author{
UNIVERSIDADE DE SÃO PAULO \\ INSTITUTO DE PSICOLOGIA
}

ANDREA BIANCHINI TOCCHIO

\title{
Educação permanente de profissionais de Enfermagem da Atenção Básica à Saúde a partir de Indicadores Clínicos de Risco para o Desenvolvimento Infantil
}

São Paulo

2013 


\title{
ANDREA BIANCHINI TOCCHIO
}

\section{Educação permanente de profissionais de Enfermagem da Atenção Básica à Saúde a partir de Indicadores Clínicos de Risco para o Desenvolvimento Infantil}

\author{
(Versão Corrigida)
}

\begin{abstract}
Dissertação apresentada ao
Instituto de Psicologia da Universidade de São Paulo, como parte dos requisitos para obtenção do título de Mestre em Psicologia

Área de concentração: Psicologia Escolar e do Desenvolvimento Humano
\end{abstract}

Orientador: Prof. Rogério Lerner

São Paulo

2013 
AUTORIZO A REPRODUÇÃO E DIVULGAÇÃO TOTAL OU PARCIAL DESTE TRABALHO, POR QUALQUER MEIO CONVENCIONAL OU ELETRÔNICO, PARA FINS DE ESTUDO E PESQUISA, DESDE QUE CITADA A FONTE.

\author{
Catalogação na publicação \\ Biblioteca Dante Moreira Leite \\ Instituto de Psicologia da Universidade de São Paulo
}

Tocchio, Andrea Bianchini.

Educação permanente de profissionais de enfermagem da atenção básica à saúde a partir de indicadores / Andrea Bianchini Tocchio; orientador Rogério Lerner. -- São Paulo, 2013.

$179 \mathrm{f}$.

Dissertação (Mestrado - Programa de Pós-Graduação em Psicologia. Área de Concentração: Psicologia Escolar e do Desenvolvimento Humano) - Instituto de Psicologia da Universidade de São Paulo.

1. Educação permanente 2. Desenvolvimento infantil 3. Equipe de enfermagem 4. Psicanálise 5. Saúde coletiva I. Título. 
Nome: Tocchio, Andrea Bianchini

Título: Educação permanente de profissionais de Enfermagem da Atenção Básica à Saúde a partir de Indicadores Clínicos de Risco para o Desenvolvimento Infantil

Dissertação apresentada ao Instituto de Psicologia da Universidade de São Paulo, como parte dos requisitos para obtenção do título de Mestre em Psicologia

Aprovado em:

Banca Examinadora

Prof. Dr.

Instituição:

Assinatura:

Prof. Dr.

Instituição:

Assinatura:

Prof. Dr.

Instituição: Assinatura: 


\section{AGRADECIMENTOS}

Ao meu orientador Rogério Lerner, pelo imenso entusiasmo em transmitir e produzir conhecimento. Por participar do meu desenvolvimento profissional e acadêmico há 12 anos. Por sempre acreditar na minha capacidade e me dar suporte em vários aspectos e momentos que precisei, principalmente diante da dificuldade de escrever.

À Dra ${ }^{\mathrm{a}}$. Rosa Resegue e Walquiria Castello Branco, integrantes do Projeto Desenvolver, vinculado ao Departamento de Pediatria da Universidade Federal de São Paulo, que viabilizaram o campo de trabalho dessa pesquisa.

A todos da secretaria de saúde e educação em saúde do município de Embu, que possibilitaram essa pesquisa, em especial: Katia Paiva, Denise Condeixa, Dra ${ }^{\mathrm{a}}$. Rita de Cássia Kisukuri.

A todos os participantes dessa pesquisa, profissionais que enfrentam a dura realidade da assistência do sistema público de saúde, pela generosa parceria nesses 20 meses de trabalho.

À Audrey Setton, pelas simples e certeiras orientações na banca de qualificação, além de apontamentos de falta de clareza e compreensão da minha escrita, que me fizeram avançar.

À Maria Madalena Januário Leite, professora da EEUSP, pelos ajustes necessários trazidos na banca de qualificação e pelas riquíssimas contribuições da área da saúde e educação em enfermagem.

Ao Vinícius David, psicólogo e metodólogo do IPUSP, que esteve sempre disponível para discutir e rever os entraves metodológicos dessa pesquisa, contribuindo com brilhantes ideias para execução das análises.

Ao Luiz Silva, também funcionário do IPUSP, pelos preciosos auxílios com análises estatísticas, tabelas, gráficos, e usos de programas, como Excel e SPSS.

À Samira Orra, pela primeira revisão do texto incipiente, que lhe exigiu árduo trabalho. 
À Betty Salum, professora de redação acadêmica da FFCLH, que operou como uma psicanalista para minha escrita, tornando-a mais fluida e compreensível, sem que eu me desse conta.

Ao Jonathan Miller, aluno de graduação do IPUSP, pelo implicado empenho na categorização de respostas dadas pelas participantes, para realização do teste Kappa.

Ao Aleix Altimiras, que sem saber, me transmitiu que escrever é possível, me apresentando às sessões de escrita e às técnicas de como escrever uma dissertação.

À Capes, Fapesp pelo apoio financeiro e à USP, conhecida como mãe-tenedora, pelas instalações e facilidades à moradia, alimentação, transporte, assistência médica e odontológica, práticas esportivas, cursos de francês e redação, além de auxílios viagens para apresentação desse trabalho.

Aos meus pais que sempre acreditaram na minha liberdade e autonomia e permitiram que eu fosse livre para escolher o que queria.

A minha irmã, generosa e desprendida, que sempre disponibilizou seus bens materiais para auxiliar o trabalho de campo, mesmo que isso tenha nos custado um motor automotivo novo e meses sem carro. Meu eterno obrigada!

Aos primos Bruna, pela sua disponibilidade em confeccionar os fluxogramas ilustrativos dessa pesquisa e querido Thiago, pela preciosa e excelente versão do resumo para o inglês.

À tia Claudia, que prazerosamente revisou este texto e também pôde aprender com ele. Agradeço muito o cuidadoso trabalho!

À querida Ana Silvia, mais do que parceira nessa árdua tarefa, pelo interminável desejo de saber, pela precisão ao empregar as palavras e pela transmissão da arte em lapidar textos. Pela amizade que pôde extrapolar os muros acadêmicos mundo afora e me proporcionar novas experiências e conversas profundas, principalmente sobre o feminino.

Ao amigo Maged, pelo carinho e acolhimento no momento mais dolorido da minha vida. Saudades da sua generosidade e de seus abraços de urso. Agradeço também as preciosas leituras deste texto. 
Aos queridos Vitor e Lígia, mais do que companheiros de IPUSP, verdadeiros amigos, que sempre me deram ânimo ao dividir e acolher momentos de tensão da vida acadêmica, assim como passeios e trocas de experiências de vida.

Às amigas do grupo de pesquisa, que ultrapassaram essa configuração para verdadeiras e profundas relações, principalmente: Angela, Gabriela, Nathalia, Marcia, Luciana e Julia.

À Cinthia Jank, que possibilitou importantíssimas construções simbólicas e essenciais objetos internos, que sanaram falhas na minha constituição subjetiva.

Aos colegas, pós-graduandos do IFUSP Samuel, Miguel, Michel, por compartilharem a árdua tarefa de fazer pesquisa, principalmente André Luiz pelas ricas trocas científicas. Por me apresentar a perspectiva crítica das ciências exatas e naturais. Por todos momentos felizes, como pedaladas de domingo e o inesquecível temaki do posto.

Ao amigo Ronaldo Coelho, por me acolher nos primeiros anos do mestrado e por me apresentar a vida uspiana e os impasses da universidade pública.

A todos que conviveram comigo na república do Mauro, também chamada de maurolândia e casa amarela, saudosamente: Samuel, Michel, Roger, Argentino, Dani, Renato, João, Elys, Vitor, André, Samira e Maged. E também às amigas do eventual, especialmente Sandra, Irene e Grazi.

A todos os funcionários do IPUSP, principalmente Sandra, Olivia, Ari que sempre me acolheram nessa instituição.

A todos os professores do IPUSP, em especial do PSA: Marie Claire, Maria Thereza, Iraí, Isabel e Rogério por sempre estarem dispostos a compartilhar seus espaços e me permitirem fazer parte desse instituto nesses 3 anos.

Aos funcionários do CEPE-USP, carinhosamente aos professores Marcos, Érica, Guilherme, por me beneficiarem momentos de descontração e relaxamento, e claro, à Paula que aprimorou minha corrida e me apresentou as excitantes corridas de rua e à Vera que me ensinou a correr dentro d'água, aliviando o impacto e as dores.

À vida, por me proporcionar todas essas experiências vibrantes e ao Pai Maior, pela força nos momentos difíceis. 
A porta da verdade estava aberta mas só deixava passar meia pessoa de cada vez.

Assim não era possivel atingir toda a verdade, porque a meia pessoa que entrava só conseguia o perfit de meia verdade. E sua segunda metade voltava igualmente com meio perfit. E os meios perfis não coincidiam.

Arrebentaram a porta. Derrubaram a porta. Chegaram ao higar huminoso onde a verdade esplendia or sens fogos. Era dividida em duas metades diferentes uma da outra.

Chegou-se a discutir qual a metade mais bela. Nenhuma das duas era perfeitamente bela.

E era preciso optar. Cada um optou conforme sew capricho, sua ilusão, sua miopia.

Carlos Drummond de Andrade Contos Plausiveis, 1985 


\section{RESUMO}

Tocchio, A. B. (2013). Educação permanente de profissionais de Enfermagem da Atenção Básica à Saúde a partir de Indicadores Clínicos de Risco para o Desenvolvimento Infantil. Dissertação de Mestrado, Instituto de Psicologia, Universidade de São Paulo, São Paulo.

Introdução: Formações de profissionais de saúde nem sempre abordam a subjetividade do bebê, deixando uma lacuna entre aspectos psíquicos do desenvolvimento infantil e seus eventuais problemas. A educação permanente em saúde (EPS) é uma política de formação de trabalhadores da saúde a partir de estratégias de ensino contextualizadas e participativas para a transformação de práticas. Assim, realizamos uma proposta de educação permanente com estratégias formativas dirigidas às profissionais de enfermagem do município de Embu, com a transmissão de Indicadores Clínicos de Risco para o Desenvolvimento Infantil - IRDI, que verifica a instalação da constituição psíquica e do desenvolvimento do bebê de até 18 meses. Objetivos: Acompanhar efeitos de ações formativas, considerando 2 contextos: em que medida os participantes se apropriam dos fundamentos do IRDI e do aspecto relacional entre bebê e seus familiares, e verificar como os profissionais acompanham a população infantil em seus dispositivos de saúde com o uso do protocolo. Método: Como estratégias formativas, efetuamos uma intervenção em educação permanente ao longo de 1 ano e 6 meses, estruturada com 4 encontros onde foram apresentados aspectos formais das 4 faixas etárias do IRDI, sendo intercalados por monitorias em serviço feitas pela pesquisadora. Os objetivos desse trabalho foram respondidos a partir de evidências em 3 âmbitos: 1- 12 profissionais que fizeram a formação (grupo intervenção) responderam, antes e após a mesma, a questionários quanto à sua prática com bebês para a comparação dos resultados obtidos; as respostas também foram comparadas com as de profissionais que não passaram pela formação, servindo como grupo controle. As respostas foram classificadas quantitativamente em 2 categorias: aspectos físicos e aspectos psicológicos, tais como citação da interação mãe/bebê de forma inespecífica e menção à interação de maneira refinada, citando itens do IRDI ou seus fundamentos. 2- evidências de transformações, quantitativas e qualitativas, quanto à concepção de aspectos psicológicos, ao longo do tempo, do grupo que participou da intervenção. 3- discussão de alguns sentidos, tanto favorecedores quanto defensivos, que a formação teve para os que passaram por ela. Resultados: As análises quantitativas indicam que houve uma intensificação e especificação de menção de aspectos subjetivos da interação do bebê com seus cuidadores e consideração da importância disso para o desenvolvimento infantil pelo grupo intervenção. As análises qualitativas evidenciaram que ao considerarmos a subjetividade dos participantes e demais envolvidos na educação permanente ficamos diante da possibilidade de ressignificar práticas, bem como de relações dos profissionais estabelecidas entre seus familiares, pacientes, equipe de trabalho e com o próprio trabalho. Considerações Finais: As ações em educação permanente propostas nesse trabalho nem sempre ocorreram conforme suas diretrizes, no entanto, atingimos uma apropriação de aspectos emocionais do desenvolvimento infantil a partir de diferentes níveis: cognitivo, subjetivo e institucional. Conclui-se que para possibilitar avanços mais efetivos em intervenções de educação permanente para apropriação do IRDI, se faz necessária uma formação pouco técnica e mais aproximativa/subjetiva com acompanhamento contínuo dos participantes, além do apoio e da participação institucional das gerências e secretarias dos serviços de saúde envolvidos. Palavras-chave: educação permanente; desenvolvimento infantil; equipe de enfermagem; psicanálise; saúde coletiva. 


\begin{abstract}
Tocchio, A. B. (2013). Continuing education of primary healthcare nursing professional's using Clinical Risk Indicators for Child Development. Master's Dissertation, Institute of Psychology, University of São Paulo, São Paulo.
\end{abstract}

Introduction: Proposals for continuing education do not always consider the subjectivity, therefore creating a gap in the training of healthcare professionals in relation to psychological aspects of child development and its potential problems. Continuing Healthcare Education (CHE) is a policy of training of healthcare workers from contextualized and participatory teaching strategies so transformation in practices it is achieved. Accordingly, we conducted training strategies directed at nursing staff of the county of Embu, with the approach of Clinical Risk Indicators for Child Development (CRICD) - Indicadores Clínicos de Risco para o Desenvolvimento Infantil (IRDI), which verifies the installation of the psychic constitution and development of the baby up to 18 months. Objectives: Monitor the effects of formative actions, considering two contexts: the extent to which participants take in consideration the fundamentals of CRICD and the relational aspect between babies and their families, and verify how the healthcare professionals monitor the child population regarding their health using protocol. Method: As training strategies, we establish a continuing education program during 1 year and 6 months with 4 structured meetings where they were presented formal aspects of the CRICD 4 age groups, being combined with the formal meetings several tutoring in service made by the researcher. The objectives of this work were completed from evidence in three areas: $1-12$ healthcare professionals who have attend the CRICD training (intervention group) responded, before and after it, the questionnaires regarding their practice with babies to compare the results obtained; the responses were also compared with professionals who have not gone through training, serving as a control group. Responses were classified quantitatively into 2 categories: physical aspects and psychological aspects, such as statement of mother/baby interaction in a nonspecifically manner and reference of a refined way of interaction, mentioning items of CRICD or its foundations. 2 - evidence of transformation, in both quantitative and qualitative, on the design of psychological aspect, over time with the group that took place in the intervention. 3 - discussion of some meanings, taking in consideration both facilitates and defensives, of that training for the healthcare professionals who had passed through it. Results: Quantitative analysis indicated that there was an intensification and specification in the subjective aspects of the interaction between babies and their guardians, and therefore the consideration of the importance of this manner for the child development by intervention group. Qualitative analyzes showed that when considering the subjectivity of the participants and others involved in continuing education we are faced with the possibility of re-signifying practices, as well as the professional relationships established between their families, patients, team work and the work itself. Final Considerations: The actions in continuing education proposals in this work were not always in accordance with their guidelines, however, reached a settlement with the emotional aspects of child development from different levels: cognitive, subjective and institutional. We conclude that to enable more effectiveness interventions in continuing education for appropriating CRICD, a highly technical training is not needed but instead a more subjective one with continuous monitoring of participants as well as the support and participation from institutional managements departments of the healthcare services involved. Keywords: Continuing education; childhood development; nursing team; psychoanalysis; public health 


\section{LISTA DE ABREVIATURAS}

AE - Atendimento de Enfermagem em Pediatria

ASD - Transtorno do Espectro de Autismo

AP3 - Avaliação Psicanalítica aos 3 anos

CHAT - Checklist for Autism in Toddlers

EPS - Educação Permanente em Saúde

ESF - Estratégia Saúde da Família

IRDI - Indicadores Clínicos de Risco para o Desenvolvimento Infantil

M-CHAT - Modified Checklist for Autism in Toddlers

PREAUT - Programa de Estudos e Pesquisas em Autismo

QDC - Questionário do Desenvolvimento da Comunicação

UBS - Unidade Básica de Saúde 


\section{SUMÁRIO}

\section{Introdução}

1.1 Saúde Coletiva e o Sistema Único de Saúde

p. 15

1.2 Educação Permanente em Saúde

\section{Indicadores Clínicos de Risco para o Desenvolvimento Infantil - IRDI}

2.1 IRDI, de onde veio?

p. 25

2.2 Onde e como chegou?

2.3 Por onde tem andado?

2.4 Para onde fomos, nesse trabalho?

p. 38

\section{Objetivos}

3.1 Objetivos específicos

4. Método

4.1 Estratégias para intervenção em educação permanente

4.2 Os quatro encontros formativos

4.3 Contextualizando o local do estudo e algumas práticas dos participantes

4.4 Instrumentos e procedimentos para coleta de dados

4.4.1 Fichas de Acompanhamento

4.4.2 Acompanhamentos em serviço

4.5 Caracterização dos participantes dos grupos controle e intervenção

p. 62

\section{Resultados e Discussão}

5.1 Número de participantes ao longo do estudo

p. 66

5.2 Entendendo as "desistências"

p. 69

5.3 Resultados obtidos com as questões fechadas

p. 73

5.3.1 Resultados da Primeira Ficha de Acompanhamento

5.3.2 Resultados da Segunda Ficha de Acompanhamento

p. 77

5.3.3 Comparações dos resultados da Primeira e da Segunda Ficha de Acompanhamento 
Conclusão

5.4 Resultados quantitativos e qualitativos das questões abertas $\quad$ p. 84

$\begin{array}{lr}\text { 5.4.1 Comparações entre os grupos intervenção e controle } & \text { p. } 84\end{array}$

5.4.1.1 Análise de aspectos físicos e psicológicos citados nos grupos intervenção e p. 84 controle

5.4.1.2 Frequências de citações de aspectos psicológicos nos grupos intervenção e p. 87 controle

5.4.2 Comparações entre as respostas obtidas pelo grupo intervenção antes, durante e p.92 após a formação

5.4.2.1 Análise de aspectos físicos e psicológicos citados pelo grupo intervenção nos três p. 92 momentos

5.4.2.2 Frequência de citações de aspectos psicológicos pelo grupo intervenção nos três $\quad$ p. 94 momentos

5.4.2.3 O que há nos aspectos psicológicos?

p. 99

5.4.2.4 Afinal, o que há de específico nos aspectos psicológicos?

p. 106

5.5 Uma perspectiva qualitativa de apropriação do IRDI

p. 115

5.5.1 Principais dificuldades encontradas

p. 116

5.5.2 Evidências de apropriação do IRDI e engajamento na formação

p. 128

\section{Considerações finais}

p. 140

\section{Referências}

p. 145

\section{Apêndices}

Apêndice A

p. 151

Apêndice B

p. 159

Apêndice C

p. 160

Apêndice D

p. 163

Apêndice E

p. 166

Apêndice F

p. 169

\section{Anexos}

Anexo A

p. 174

Anexo B

p. 179 
1. Introdução 


\subsection{Saúde Coletiva e o Sistema Único de Saúde}

Spink e Matta (2007), ao discutirem a heterogenia entre os campos da Saúde Pública e da Saúde Coletiva, referem-se à Birman (2005) como um de muitos autores que apontam diferenças básicas entre esses dois saberes. Birman, citado por Spink e Matta (2007), menciona a preocupação epidemiológica e o enquadre do espaço urbano em medidas sanitárias da Saúde Pública, buscando fundamentação na Biologia e Estatística. Em contrapartida, considera a Saúde Coletiva uma crítica às categorias universalizantes da Saúde Pública e, portanto, ao saber médico, estando associada à entrada das Ciências Humanas na Saúde, se propondo à multidisciplinaridade, inclusive à Psicologia.

Spink e Matta (2007), baseados em no trabalho de Paim e Almeida Filho de 1998, consideram a Saúde Coletiva um campo científico no qual diferentes disciplinas produzem conhecimento sobre a "saúde", assim como um campo de práticas com ações realizadas fora e dentro do setor por diversas organizações, instituições e agentes.

Diante disso, a Saúde Coletiva, no campo de práticas, apresenta a marca da multidisciplinaridade, articulando-se com ações em comunidade e outros espaços de sociabilidade, que a faz ampliar suas concepções de objetos de intervenção e consequentemente de prevenção e atenção primária, passando a pautar-se por outros conceitos como promoção à saúde e qualidade de vida (Spink \& Matta, 2007). No campo do conhecimento, afirmam a possibilidade de diálogo bastante proveitoso entre a Psicologia e a Saúde Coletiva, nas seguintes áreas:

na compreensão das práticas de saúde, nas maneiras como a população identifica, explica e busca solução para suas necessidades de saúde; nos processos de comunicação social em saúde. Ou seja, a Psicologia pode contribuir retomando, na Saúde, a problemática do sujeito e, a partir de pesquisas e teorizações mais críticas que se contraponham aos modelos universalizantes e biologizantes da Saúde Pública, pode enriquecer o campo da Saúde Coletiva (Spink \& Matta 2007, p.161)

A problemática do sujeito é mesmo o que interessa à Psicologia e quando associada à Saúde Coletiva se insere em tensões decorrentes de jogos de conflitos de demandas, interesses, desejos e necessidades. Campo esse, também, configurado pelo Sistema Único de Saúde (SUS) onde, embora haja avanços significativos para a saúde da população brasileira desde a década de 90, “existem impedimentos de diversas ordens (para o funcionamento do sistema), com destaque para 
o sub-financiamento e a precarização da gestão de pessoal", acarretando queda na qualidade do serviço (Scarcelli \& Junqueira, 2011, p.342). Em consequência, apresentam-se as várias insuficiências do serviço: escassez de funcionários, ausência de equipe multiprofissional, desarticulação dos serviços, principalmente entre a atenção básica e os demais, além de funcionamento privatista dos ambulatórios de especialidades e hospitais. Discursos que priorizam a atenção básica, como o da ampliação de equipes da Estratégia Saúde da Família (ESF), não se concretizam realmente, devido à desvalorização e ausência de incentivos salariais dos profissionais. Sem contar a terceirização desse dispositivo, deixando a atenção básica na mão de instituições privadas e longe do controle do Estado (Scarcelli \& Junqueira, 2011).

Esses são alguns impasses descritos por Scarcelli e Junqueira (2011, p.343) que contradizem princípios e "estratégias (do SUS) para executar políticas públicas e implementar práticas”. São impasses que revelam uma disputa de projetos entre sistemas nacionais de saúde e alternativas liberais-privatistas diante de diferentes "concepções de Estado, sociedade, sujeito, saúde e educação" (p.343), de todos os envolvidos: "governantes, partidos políticos, empresários, movimentos sociais, estudantes, intelectuais, entidades, filantrópicas, conselhos profissionais, associações de classes, sindicatos, etc.” (Scarcelli \& Junqueira, 2011, p. 344).

O SUS nasce de um movimento social; foi ainda na luta contra a ditadura militar que se constituiu o movimento pela Reforma Sanitária Brasileira, devido a articulações entre estudantes e militantes. Ideias da reforma sanitária ganham força em 1986, com a VII Conferência Nacional Constituinte, sendo retomadas na Assembleia Nacional Constituinte entre 1987 e 1988 e posteriormente, institui-se a Lei do SUS, de 1990, baseada no artigo 198 da Constituição de 1988 (Andrade \& Barreto, 2007).

Scarcelli e Junqueira (2011) apontam que o SUS apresenta, desde sua criação até atualmente, diversos conflitos de interesses distintos, muitas vezes antagônicos. Um deles é a contradição existente entre seus princípios de interesses públicos e seus direcionamentos, muitas vezes a partir de interesses privados, tendo como aliados empresários da assistência médica e da indústria farmacêutica. Vejamos adiante seus princípios doutrinários:

Universalidade, ou seja, todos, independente de classe social, raça, cor, gênero, crença, têm direito a cobertura e atendimento pelo sistema de saúde; 
Igualdade: todos devem ser atendidos igualmente na utilização do sistema, que deve considerar as diferentes necessidades dos usuários;

Integralidade: desenvolvendo ações integrais à saúde (proteção, promoção e recuperação) ao considerar o indivíduo nas suas dimensões físicas, psíquicas e sociais.

O SUS apresenta também os seguintes princípios organizativos fundamentais: descentralização por meio da municipalização, regionalização com hierarquização da atenção, dividindo os serviços de saúde em níveis de complexidade com o intuito de permitir o acesso à toda população de maneira mais eficiente. (Andrade \& Barreto, 2007)

Conta ainda com o controle social, ou seja, participação popular em conselhos deliberativos para controle de formulação e execução política de saúde, nas instâncias federal, estadual, municipal e local (Scarcelli \& Junqueira, 2011).

\subsection{Educação Permanente em Saúde}

A Educação Permanente em Saúde (EPS) é uma política pública formulada pelo Ministério da Saúde que pretende se comprometer com a formação do profissional de saúde ao articular diversas instâncias, como educadores, gestores, trabalhadores e suas práticas de atenção, e controladorias sociais em saúde, como a participação ativa da sociedade em decidir sobre formulações, execuções e avaliações do SUS (Ceccim e Feuerwerker, 2004; Peduzzi, Guerra, Braga, Lucena, \& Silva, 2009; Freitas, 2011). A formação em serviço é uma estratégia pedagógica sustentada pelos princípios e diretrizes do SUS e, por sua vez, auxilia no seu fortalecimento.

A EPS tem como pressuposto que a reflexão sobre o processo de trabalho seja um desencadeador de processos educativos que oferecem possibilidades de problematizar a própria realidade do trabalho, compreendendo-o e transformando-o. Na tentativa de superar capacitações verticais que pouco contribuem para modificações de práticas dos trabalhadores de saúde, o modelo da EPS foi 
proposto tendo como ponto de partida o que já se sabe para construção de novos conhecimentos (Peduzzi et al., 2009; Freitas, 2011).

Intervenções em educação permanente buscam que a aprendizagem seja significativa a partir de experiências prévias quanto ao processo de trabalho já instituído e de experimentações da alteridade com os usuários, como relata Campos (2003). Segundo o autor, ao repensar o cuidado e modos de fazer saúde, há que se retornar a intervenção para o sujeito, fazendo-o refletir sobre seu contexto social e cultural e assim ampliar sua autonomia ao ponto de permiti-lo intervir em sua própria vida. Em consequência dessas ações, a educação permanente permite que relações envolvidas na organização e estruturação do cuidado à saúde se incorporem ao apreender e ao ensinar e que diante disso novas práticas possam se instalar, melhorando a integridade à saúde e beneficiando a população assistida. Como afirmam Tesser, Garcia, Vendruscolo e Argenta (2011, p.4296):

A educação permanente oferece elementos valiosos ao prover uma visão geral filosófica-política e técnica-pedagógica para o processo de formação e aperfeiçoamento constante dos profissionais da saúde em relação aos desafios de seu trabalho cotidiano. É fundamentada na concepção de educação como transformação e aprendizagem significativa, centrada no exercício cotidiano do trabalho e na valorização deste como fonte de conhecimento, na valorização da articulação da atenção à saúde com a gestão e o controle social e no reconhecimento de que as práticas são definidas por múltiplos fatores. Volta-se à multiprofissionalidade e à interdisciplinaridade, com estratégias de ensino contextualizadas e participativas, e orienta-se para a transformação das práticas.

Tendo como disparador o próprio processo de trabalho como problematizador, reflexivo e questionador, intervenções em EPS podem direcionar-se para relações entre equipes e gestores, mais do que em atuações de profissionais com usuários, como sustenta Freitas (2011, p.13):

Possivelmente se poderá perceber a necessidade de aprofundar o conhecimento técnico-científico dos profissionais envolvidos nas ações, mas certamente também serão percebidas necessidades de intervenção na organização dos serviços, na gestão, na forma de desenvolver as ações intersetoriais e outras tantas questões.

Diante da argumentação acima, concluímos que a EPS não é exclusividade dos educadores; demanda-se a atuação dos gestores para que ela se concretize como proposta de intervenção política-pedagógica. No entanto, Ceccim e Feuerwerker (2004, p.42), baseados em estudos anteriores, apontam que, na prática, instituições de ensino não sustentam ações necessárias para efetivar intervenções em educação permanente: 
A formação dos profissionais de saúde tem permanecido alheia à organização da gestão setorial e ao debate crítico sobre os sistemas de estruturação do cuidado, mostrando-se absolutamente impermeável ao controle social sobre o setor, fundante do modelo oficial de saúde brasileiro. As instituições formadoras têm perpetuado modelos essencialmente conservadores, centrados em aparelhos e sistemas orgânicos e tecnologias de apoio diagnóstico e terapêutico.

O que se espera, mais do que ações tradicionais em saúde (diagnóstico, tratamento, prognósticos, etiologia e profilaxia de doenças), é uma atuação politizada das pessoas envolvidas para influenciar na formulação de novas políticas do cuidado e necessidades da população assistida. Como ainda mencionam Ceccim e Feuerwerker (2004, p. 43):

A atualização técnico-científica é apenas um dos aspectos da qualificação das práticas e não seu foco central. A formação engloba aspectos de produção de subjetividade, produção de habilidades técnicas e de pensamento e o adequado conhecimento do SUS. A formação para a área da saúde deveria ter como objetivo a transformação das práticas profissionais e da própria organização do trabalho, e estruturar-se a partir da problematização do processo de trabalho e sua capacidade de dar acolhimento e cuidado às várias dimensões e necessidades de saúde das pessoas, dos coletivos e das populações.

Esses autores afirmam ainda que seriam as instâncias do SUS as responsáveis em contribuir para mudanças de práticas de saúde e formação profissional. Articulações entre sistema de saúde, contando com todas suas esferas e instituições formadoras agregariam em "desenvolvimento individual e institucional, entre serviços e gestão setorial e entre atenção à saúde e controle social" (Ceccim e Feuerwerker, 2004, p.45). No entanto, percebe-se que limitações de políticas públicas do SUS e das parcerias entre gestores tanto com controladorias sociais quanto com instituições de ensino comprometem ações em educação em saúde:

Por se apresentarem de forma desarticulada ou fragmentada e corresponderem a orientações conceituais heterogêneas, as capacidades de impacto das ações do SUS em educação têm sido muito limitadas, no sentido de alimentar os processos de mudança sobre as instituições formadoras, e nulas em apresentar a formação como uma política do SUS: potência de interpor lógicas, diretrizes e processos organizados, coerentes e desafiadores dos modos de fazer. (Ceccim e Feuerwerker, 2004, p.45)

Resumindo, a educação em serviço é um recurso estratégico por articular práticas de saúde e pedagógicas, implicando trabalho integrado entre o sistema de saúde e suas esferas de gestão e instituições formadoras, mas muitas vezes ainda incipiente. Freitas (2011, p. 68), em estudo que avaliou o modo como a EPS ocorre em uma região de São Paulo afirmou: "é um processo que 
está em andamento e que a construção de um espaço de articulação, diálogo e pactuação requer tempo, disposição para mudanças, investimento em pessoas e firme interesse na transformação.”

Não nos faltam evidências de que muito trabalho necessita ser feito e muito investimento nem sempre concreto, palpável e visível está por vir. Quanto a isso, há um agravante ainda maior quando se esbarra na Saúde Mental, uma vez que a esfera psíquica demanda um posicionamento no trabalho diferente do habitual, bem como recursos psíquicos do próprio profissional. Além do mais, a formação acadêmica nem sempre contempla os aspectos psíquicos do profissional que precisam ser trabalhados (Silva et al., 2004).

Vejamos, a seguir, algumas tentativas de educação permanente nessa área.

No livro Promoção da Saúde da Criança (Chiesa et al., 2009) apresenta-se o projeto Nossas Crianças: Janelas de Oportunidades, idealizado por pesquisadoras em Enfermagem, como processo de formação de profissionais de saúde para a ação de promoção do desenvolvimento infantil, que objetivou ampliar a visão de desenvolvimento para o conjunto de relações experimentadas e aprendidas pela criança e por toda família na sua rotina familiar e social; é favorecer o vínculo, proporcionando proximidade e confiança entre todos os envolvidos no cuidado à criança.As autoras referem-se à importância do cuidado para com o infante, na medida em que lhe é proporcionado um melhor desenvolvimento quando possui o suporte de cuidados específicos tanto físicos como emocionais. Considera-se a perspectiva socioambiental e emocional intrínseca ao processo saúde-doença. Buscou-se trabalhar com a equipe que compõe a Estratégia da Saúde da Família (ESF) como um todo, mas percebe-se principalmente o foco nos agentes comunitários de saúde (ACS).

Avaliou-se a implantação do projeto e do material, composto por uma cartilha com assuntos e ilustrações de interesse para as famílias acompanhadas e um manual de apoio para os agentes comunitários e profissionais da ESF, contendo informações sobre o desenvolvimento de crianças de até seis anos de idade e orientações práticas de como trabalhar com as famílias assistidas. Apenas 12,3\% dos agentes de saúde usavam a cartilha no momento da pesquisa, mas 81,6\% já haviam usado a cartilha anteriormente. O que possibilitou a descontinuidade do uso do material? O manual foi lido completamente por 54,6\% dos agentes, enquanto 43,3\% leram alguns capítulos. Quem foi treinado teve maior interesse em ler o manual e em usar a cartilha. Ou seja, 
aponta-se para a importância do contato, da discussão, e da forma de estruturação da própria formação.

As autoras apontam que o desuso do material reflete desafios da implantação do próprio PSF, ou seja, da própria forma como a saúde pública está estruturada no modelo tradicional de educação em saúde, "sendo necessário repensar o modelo de educação em saúde proposto para a promoção da saúde, e o investimento no processo de capacitação e acompanhamento das atividades desenvolvidas”. (Chiesa et al., 2009, p. 119)

Observamos que os idealizadores desse projeto fazem uma autocrítica quanto à descontinuidade na formação dos profissionais. Houve um enfraquecimento nas ações do projeto, especificamente no uso do material (cartilha e manual) por parte dos agentes comunitários diante de ausências de retaguarda e continuidade na formação. As autoras afirmam que a construção de conhecimentos mais fortalecidos se dá na proximidade com os profissionais, e apontam para a necessidade de supervisores trabalhando em conjunto, proporcionando discussões sobre o material e sobre a novidade na atuação (Chiesa et al., 2009).

Em concordância, Souza, Alencastre e Saeki (2000) reafirmam a necessidade de atividades práticas realizadas em conjunto, sejam reuniões ou supervisões, no âmbito de atualizações de práticas na saúde:

Os treinamentos e capacitações (...) não devem ater-se exclusivamente a aulas, cursos e palestras voltados apenas para o treinamento técnico. (...) Faz-se necessário um acompanhamento mais próximo do pessoal, com supervisões sistematizadas que visem também as relações humanas no trabalho. (p. 72).

As autoras referem ainda que a supervisão deve ser encarada como uma articulação entre a teoria e a prática e não como um processo de normatização do trabalho como é comum na área de enfermagem. Apontam também para necessidades urgentes de formação de profissionais de enfermagem específica em ações em Saúde Mental, uma vez apontadas falhas nesse processo e negligências quanto aos aspectos emocionais dos pacientes e dos próprios profissionais.

Pinto-Martin, Souders, Giarelli e Levy (2005) realizaram um trabalho com o objetivo de implantar uma rotina de avaliação do desenvolvimento infantil em visitas de puericultura em um hospital da Pensilvânia. Devido a não avaliação do desenvolvimento infantil pelos pediatras, 
surgiu a ideia de transformar essa prática em mais um procedimento da equipe de enfermagem, assim como pesagem e medição de bebês. A princípio, estabelecer a avaliação do desenvolvimento infantil pela equipe de enfermagem tinha a finalidade de possibilitar que as mães relatassem mais dúvidas e queixas quanto a esse aspecto de seus filhos.

O projeto piloto foi estabelecido para a detecção de transtorno do espectro de autismo (ASD), embora se pretendesse avaliar desenvolvimento como um todo. Utilizou-se o instrumento The Checklist for Autism in Toddlers: CHAT, que avalia o comportamento social da criança, como brincadeiras, pontos de atenção, interação. Cinco aspectos comportamentais são observáveis e nove perguntas respondidas pelos pais. Crianças que apresentam falhas em cinco itens são de alto risco para ASD. A sensibilidade desse instrumento para detectar ASD é somente de 18\%. Já o Modified Checklist for Autism in Toddlers: M-CHAT é considerado um instrumento de detecção e também foi utilizado.

Pediatras, médicos assistentes, enfermeiros e auxiliares de enfermagem foram formados para utilizarem o CHAT e M-CHAT. No entanto, não há informações específicas sobre como ocorreu essa formação. Foram levantados alguns complicadores: a aplicação do instrumento causou mais atrasos no serviço, uma vez já se tratava de um ambiente ocupado; houve recusa de pais e profissionais em participarem da pesquisa. Concluiu-se que o atual sistema de cuidados pediátricos não dispõe de tempo para novos procedimentos de rotina. Procedimentos novos devem ser rápidos e fáceis de ser administrados. Percebe-se que nos serviços de saúde há pouco espaço para se pensar em problemas de desenvolvimento infantil e em componentes subjetivos da saúde, e o desafio é instituir um lugar para tanto.

Constatamos que as mudanças em atuações em Saúde Mental e internalizações de novas possibilidades de cuidar do paciente, incluindo a esfera emocional à saúde, poderão se efetivar com muito empenho, reformas na formação de profissionais de saúde e programas que considerem a educação permanente. Entretanto, pesquisas nesse sentido têm sido escassas e, portanto, pouco se sabe como isso pode ser feito. Foi nesse contexto que realizamos uma intervenção em educação permanente que contempla aspectos subjetivos de bebês e verificamos seus efeitos para a apreensão de conhecimento e aprendizagem de profissionais de enfermagem. 
Em parceria com a Dr ${ }^{a}$. Rosa Resegue da Universidade Federal de São Paulo (Unifesp) e das secretarias de Saúde e de Educação em Saúde do município de Embu das Artes, analisamos os efeitos de uma formação extensiva para profissionais de enfermagem da atenção básica à saúde sobre o desenvolvimento infantil, utilizando Indicadores Clínicos de Risco para o Desenvolvimento Infantil (IRDI). A origem do protocolo, seus fundamentos e dados da pesquisa multicêntrica que o validou como ficha de leitura do desenvolvimento emocional infantil serão relatados no próximo capítulo, Indicadores Clínicos de Risco para o Desenvolvimento InfantilIRDI.

Na sequência, em Método, apresentamos as estratégias utilizadas para realizar a intervenção em educação permanente (que estruturou encontros formativos e monitorias em serviço), os instrumentos utilizados como procedimento de coleta de dados, bem como seus modos de análises. Nesse capítulo consta também a caracterização do campo de pesquisa e dos participantes.

Posteriormente, no capítulo Resultados e Discussão, encontram-se os resultados seguidos de discussão em vários tópicos. O primeiro mostra o número de participantes ao logo do processo. No segundo, exibimos resultados quantitativos de perguntas fechadas realizadas em dois momentos ao logo da formação. O terceiro traz elementos de perguntas abertas que foram quantificados e discutidos à luz de dados qualitativos e o quarto apresenta uma discussão qualitativa de resultados obtidos nos acompanhamentos em serviço.

Finalizamos com Considerações Finais, articulando os assuntos discutidos no presente capítulo (SUS, saúde coletiva e educação permanente em saúde) com os resultados discutidos nesse estudo. 


\title{
2. Indicadores Clínicos de
}

\section{Risco para o Desenvolvimento}

\author{
Infantil - IRDI
}




\subsection{IRDI, de onde veio?}

A ideia de construir um instrumento que avaliasse o desenvolvimento psíquico de crianças muito pequenas se deu a partir do pedido de uma pediatra e psicanalista, Dr ${ }^{\mathrm{a}}$. Josenilda Caldeira Brant, que trabalhou na área da saúde da criança do Ministério da Sáude e solicitou que a $\operatorname{Prof}^{\mathrm{a}}$. $\operatorname{Dr}^{\mathrm{a}}$. Maria Cristina Machado Kupfer, do IPUSP, incluísse indicadores psíquicos na Cardeneta de Saúde da Criança de acompanhamento do desenvolvimento, usada por profissionais da rede de saúde pública brasileira, integrante das normas de Acompanhamento do Crescimento e Desenvolvimento Infantil, do Ministério da Saúde, 2002 (Lerner \& Kupfer, 2008; Pesaro, 2010).

Foi feito, portanto, um pedido de aprimoramento das avaliações pediátricas do desenvolvimento infantil, solicitando que a subjetividade entrasse em cena num campo científico em que tem pouco espaço, ao contrário do que se considera biológico, orgânico ou cognitivo. A Prof ${ }^{\mathrm{a}}$. Kupfer, por sua vez, respondeu ser necessário realizar uma pesquisa e, assim, formulou-a solicitando primeiramente que psicanalistas também especialistas em desenvolvimento infantil elegessem indicadores psíquicos de diferentes fases de crianças de 0 a 18 meses a partir de suas experiências clínicas.

A metodologia de consultar a um grupo de experts, comum em pesquisas da área de saúde, foi usada para a construção do IRDI. Partindo da articulação entre Psicanálise e Psicologia do Desenvolvimento Infantil, Pediatria, Psiquiatria, Educação e Fonoaudiologia, construiu-se um conjunto de 31 indicadores. São indicadores de saúde e de desenvolvimento, e quando estão ausentes em bebês de até 18 meses de idade, pode-se ter um indício de que é necessário acompanhá-los, havendo a necessidade de maior cuidado.

A concepção teórica que fundamentou o IRDI (Anexo A), foi a noção de constituição subjetiva que a criança muito pequena atravessa. Entende-se que a criança nasce com uma subjetividade rudimentar que será incrementada em suas experiências com os outros que estão em sua volta. $\mathrm{O}$ bebê é construído imaginariamente na teia parental. Antes mesmo de existir, já imaginamos com quem se parecerá fisicamente, de quem herdará as características de personalidade e quais serão suas preferências que o identificam como pertencente àquela família; uma narrativa fantasmática vai se constituindo em torno do bebê, e ao nascer, todos se depararam com discordâncias entre o 
bebê real e o bebê imaginado, no entanto, é justamente essa uma parte do engodo que permitirá constituir-se (Bernardino, 2006).

Nos primeiros meses de vida, o bebê como sujeito psíquico já constituído é antecipado por quem cuida dele e vivencia momentos em que as pessoas ao seu redor supõem que ali há um sujeito, nomeando o que ele deseja e o que não deseja, o que ele gosta e não gosta, o que ele aceita e não aceita; é quando a mãe ou outro cuidador dá diferentes significações a seus movimentos, gestos, expressões, choros e assim, estamos diante da suposição de sujeito, um dos eixos que sustentam teoricamente a constituição subjetiva e consequentemente, o IRDI (Lerner \& Kupfer 2008; Kupfer et al, 2009 e 2010; Pesaro, 2010; Lerner, 2011).

Simultaneamente a esse momento e de maneira interrelacionada ao primeiro eixo, choros, gritos e gestos do bebê são entendidos por quem cuida dele como um pedido dirigido a si, que permitirá que se estabeleça uma demanda entre o bebê que grita e o cuidador que o atende, acolhendo sua demanda muitas vezes de maneira ampliada, maior do que realmente se pedia ou se pretendia com determinada atitude. Tendo o reconhecimento de sua demanda, o bebê poderá seguir constuindo demandas, que sempre serão demandas de amor, com outras pessoas com quem vier a se relacionar futuramente, sendo essas relações marcadas pelas primeiras estabelecidas com os pais. Temos aqui o segundo eixo do IRDI, o estabelecimento da demanda (Lerner \& Kupfer 2008; Kupfer et al, 2009 e 2010; Pesaro, 2010; Lerner, 2011).

Como os pais não conseguem, e nem deveriam, se fazer presentes o tempo todo, haverá intervalos entre uma suposição e outra. Acontecerá de o bebê gritar e a mãe não aparecer na hora, o bebê vai ter que aguardar um pouco e provavelmente dará outro grito e esperará, entre um chamado e outro; entre um atendimento e outro há uma alternância. Estamos diante da alternância entre a presença e a ausência e assim, o bebê terá oportunidade de fazer demandas futuras e aparecer novamente com suas vontades, e não permanecer apenas com o que supõem dele. A mãe, por outro lado, tem seus motivos para não corresponder prontamente às demandas do bebê; pode estar ocupada ou voltada para projetos pessoais, tendo outros interesses ou retomando sua atenção para o marido. Nesse momento, entra cena um terceiro, numa relação que até então era principalmente dual, é o trabalho, o marido, a esposa, os estudos, mas nem sempre apresenta essa concretude. É fundamental o caráter simbólico de interromper a alienação e 
estabelecer a entrada na cultura, exercendo a função paterna como inauguração da singularidade do bebê:

Uma mãe que está submetida à função paterna leva em conta, em sua relação com o bebê, os parâmetros que a cultura lhe propõe para orientar essa relação...O exercício da função paterna sobre o par mãe-bebê poderá ter como efeito uma separação simbólica entre eles e impedirá a mãe de considerar seu filho como um "objeto" voltado unicamente para a sua satisfação. Portanto, depende dessa função a singularização do filho e sua diferenciação em relação ao corpo e às palavras maternas (Kupfer et al, 2009, p.53).

A construção do IRDI foi definida, portanto, a partir de conceitos psicanalíticos principalmente de S. Freud, W. Winnicott e J. Lacan e fundamenta-se nos 4 eixos teóricos ${ }^{1}$ apresentados acima. Como os eixos se interrelacionam, os indicadores clínicos também podem estar sustentados por mais de um eixo teórico, como apresentados no quadro abaixo:

Quadro 1 - Indicadores clínicos de risco para o desenvolvimento infantil e respectivos eixos teóricos.

\begin{tabular}{|c|c|c|}
\hline Faixas etárias & Indicadores clínicos & Eixos teóricos \\
\hline $\begin{array}{l}0 \text { a } 4 \text { meses } \\
\text { incompletos: }\end{array}$ & $\begin{array}{l}\text { 1. Quando a criança chora ou grita, a mãe sabe o que ela quer. } \\
\text { 2. A mãe fala com a criança num estilo particularmente dirigido a ela } \\
\text { (manhês). } \\
\text { 3. A criança reage ao manhês. } \\
\text { 4. A mãe propõe algo à criança e aguarda sua reação. } \\
\text { 5. Há trocas de olhares entre a criança e a mãe. }\end{array}$ & $\begin{array}{l}\text { SS/ED } \\
\text { SS } \\
\text { ED } \\
\text { PA } \\
\text { SS/PA }\end{array}$ \\
\hline $\begin{array}{l}4 \text { a } 8 \text { meses } \\
\text { incompletos: }\end{array}$ & $\begin{array}{l}\text { 6. A criança começa a diferenciar o dia da noite. } \\
\text { 7. A criança utiliza sinais diferentes para expressar suas diferentes } \\
\text { necessidades. } \\
\text { 8. A criança solicita a mãe e faz um intervalo para aguardar sua } \\
\text { resposta. } \\
\text { 9. A mãe fala com a criança dirigindo-lhe pequenas frases. } \\
\text { 10. A criança reage (sorri, vocaliza) quando a mãe ou outra pessoa está } \\
\text { se dirigindo a ela. } \\
\text { 11. A criança procura ativamente o olhar da mãe. } \\
\text { 12. A mãe dá suporte às iniciativas da criança sem poupar-lhe o } \\
\text { esforço. } \\
\text { 13. A criança pede a ajuda de outra pessoa sem ficar passiva. }\end{array}$ & $\begin{array}{l}\text { ED/PA } \\
\text { ED } \\
\text { ED/PA } \\
\text { SS/PA } \\
\text { ED } \\
\text { ED/PA } \\
\text { SS/ED/PA } \\
\text { ED/FP }\end{array}$ \\
\hline
\end{tabular}

Continua

\footnotetext{
${ }^{1}$ Para aprofundamento dos fundamentos teóricos dos eixos e suas articulações com cada indicador Cf. Pesaro (2010).

${ }^{2}$ Dada a constituição do IRDI em aspectos relacionais entre os bebês e seus pais, o protocolo considera esses dois âmbitos, apresentando indicadores ora voltados para o bebê e ora para os pais.
} 
Conclusão

\begin{tabular}{|c|c|c|}
\hline Faixas etárias & Indicadores clínicos & Eixos teóricos \\
\hline $\begin{array}{l}8 \text { a } 12 \text { meses } \\
\text { incompletos: }\end{array}$ & $\begin{array}{l}\text { 14. A mãe percebe que alguns pedidos da criança podem ser uma } \\
\text { forma de chamar a sua atenção. } \\
\text { 15. Durante os cuidados corporais, a criança busca ativamente jogos e } \\
\text { brincadeiras amorosas com a mãe. } \\
\text { 16. A criança demonstra gostar ou não de alguma coisa. } \\
\text { 17. Mãe e criança compartilham uma linguagem particular. } \\
\text { 18. A criança estranha pessoas desconhecidas para ela. } \\
\text { 19. A criaça possui objetos prediletos. } \\
\text { 20. A criança faz gracinhas. } \\
\text { 21. A criaça busca o olhar de aprovação do adulto. } \\
\text { 22. A criança aceita alimentação semi-sólida, sólida e variada. }\end{array}$ & $\begin{array}{l}\text { ED/SS } \\
\text { ED } \\
\text { ED } \\
\text { SS/PA } \\
\text { FP } \\
\text { ED } \\
\text { ED } \\
\text { ED } \\
\text { ED }\end{array}$ \\
\hline $\begin{array}{l}\text { De } 12 \text { a } 18 \\
\text { meses: }\end{array}$ & $\begin{array}{l}\text { 23. A mãe alterna momentos de dedicação à criança com outros } \\
\text { interesses. } \\
\text { 24. A criança suporta bem as breves ausências da mãe e reage às } \\
\text { ausências prolongadas. } \\
\text { 25. A mãe oferece brinquedos como alternativas para o interesse da } \\
\text { criança pelo corpo materno. } \\
\text { 26. A mãe já não se sente mais obrigada a satisfazer tudo que a criança } \\
\text { pede. } \\
\text { 27. A criança olha com curiosidade para o que interessa à mãe. } \\
\text { 28. A criança gosta de brincar com objetos usados pela mãe e pelo pai. } \\
\text { 29. A mãe começa a pedir à criança que nomeie o que deseja, não se } \\
\text { contentando apenas com gestos. } \\
\text { 30. Os pais colocam pequenas regras de comportamento para a criança. } \\
\text { 31. A criança diferencia objetos maternos, paternos e próprios. }\end{array}$ & $\begin{array}{l}\text { ED/FP } \\
\text { ED/FP } \\
\text { FP } \\
\text { SS/FP } \\
\text { FP } \\
\text { FP } \\
\text { FP } \\
\text { FP }\end{array}$ \\
\hline
\end{tabular}

Fonte: Kupfer et al, 2009, p.54.

Enquanto a maioria das pesquisas sobre desenvolvimento privilegia sua articulação com a maturação neurológico-genética, na pesquisa IRDI foi privilegiada a relação do sujeito psíquico com o desenvolvimento, sem desconsiderar o âmbito maturacional (Kupfer et al., 2009). Foi considerada a concepção de que o psiquismo ampara todo o conjunto do desenvolvimento orgânico/maturacional, mas dele também depende.

Lerner (2011), em tese de livre docência, aponta que a constituição subjetiva e as funções do desenvolvimento dependem do substrato neurológico e também podem levar à sofisticação desse último. O sistema nervoso central funciona como um alicerce que ampara as inscrições simbólicas e para que haja a constituição do sujeito é necessário o encontro entre o alicerce biológico e o meio promissor, trasmissor do sistema simbólico (Bernardino, 2006).

Como explica Jerusalinsky (2008, p.117): 
Nos primeiros anos de vida da criança, o psiquismo e as funções mentais se encontram nos primórdios de sua formação. Dependem, para isso, de que o meio (especialmente seus pais e cuidadores) desdobre e efetue as operações necessárias para que se configurem e inscrevam as matrizes que permitem organizar seu pensamento e, em decorrência dele (consciente ou inconsciente), seus comportamentos. Trata-se de operações dirigidas a transformar o espontâneo funcionamento neurobiológico - caracterizado por automatismos e repetições determinados por mecanismos neurofisiológicos básicos - para colocá-lo a serviço da estrutura de significações que caracterizam a inserção do indivíduo humano na civilização e, por tanto, sua constituição como sujeito.

Freud (1905), nos Três Ensaios sobre a Sexualidade, já referia que os mecanismos inatos, como sucção, troca de olhares, excreção e demais são libidinizados e tornam-se ações prazerosas. "A criança substitui gradualmente os mecanismos inatos, muitos deles reflexos que a levam a interagir com adultos por um impulso de fazê-lo marcado pelas experiências jubilatórias iniciais existentes nesse enlace." (Lerner, 2011, p.29).

Como relata Bernardino (2006), o olhar do outro organiza o esquema corporal do bebê, sendo que isso não seria possível apenas pela via neurológica, devido à imaturidade biológica. Devido às

marcas simbólicas que afetam o corpo as funções fisiológicas são capazes de se aprimorarem, é por isso que dizemos que a instalação do sujeito psíquico organiza o desenvolvimento da criança (Jerusalinsky, 1999).

\subsection{Onde e como chegou?}

Os IRDI foram desenvolvidos e validados durante uma pesquisa multicêntrica que ocorreu entre 2000 e 2008, com financiamento do Ministério da Saúde, do Conselho Nacional de Desenvolvimento Científico e Tecnológico $(\mathrm{CNPq})$ e da Fundação de Amparo à Pesquisa do Estado de São Paulo (FAPESP), e teve coordenação centralizada no Instituto de Psicologia da USP - IPUSP. O grupo de especialistas, reunido pela Prof ${ }^{a}$. Dr ${ }^{a}$. Maria Cristina Kupfer, nomeado 
de Grupo Nacional da Pesquisa Multicêntrica ${ }^{3}$, conduziu a pesquisa em 9 cidades brasileiras somando 11 centros de saúde (Lerner \& Kupfer, 2008; Kupfer et al., 2009, 2010).

O IRDI propõe um acompanhamento de bebês considerando quatro faixas de idade: de 0 a 4 meses, contendo 5 indicadores; de 4 a 8 meses que apresenta 8 itens; de 8 a 12 meses, com 9 indicadores e de 12 a 18 meses, também com 9 itens. Quando os itens estão ausentes, podem indicar risco para o desenvolvimento e quando presentes, são indicadores de desenvolvimento.

Durante a pesquisa multicêntrica, os indicadores foram utilizados por pediatras previamente formados para realizarem as aplicações em consultas de puericultura, caracterizando um desenho de corte transversal, seguido de estudo longitudinal que acompanhou 727 crianças por 18 meses, atendidas nas clínicas pediátricas dos centros participantes. Dessas, 287 crianças tiveram 2 ou mais indicadores ausentes, consideradas casos e 440 apresentaram 1 ou nenhum indicador ausente, configurando o grupo controle. Foi realizada uma sub-amostra com 158 crianças consideradas casos e 122 do grupo controle e aos 3 anos de idade elas foram submetidas a uma avaliação psicanalítica $-\mathrm{AP}^{4}$. A AP3 é de uma entrevista de aproximadamente 1 hora e 30 minutos com os pais e a criança, orientada por um roteiro com 43 perguntas, a ser usado por psicanalistas.

O roteiro criado para a avaliação psicanalítica foi baseado nos 4 eixos do IRDI, acrescidos de outros 4: o brincar e a fantasia (buscamos saber se há ou não produção imaginária, ou seja, se nas brincadeiras da criança há referências ao faz de conta, aos limites e interditos e se aparecem no brincar as simbolizações de seus conflitos, caso contrário, a criança poderá apresentar ausência de desdobramento de significações e jogo associado à mecânica dos objetos), o corpo e sua imagem (verificamos se a criança apresenta uma imagem psíquica de si e se há traços da diferenciação sexual), manifestações diante das normas e posição frente à lei (procura-se saber

\footnotetext{
${ }^{3}$ O Grupo Nacional da Pesquisa Multicêntrica foi constituído por Leda M. Fischer Bernardino, da PUC-Curitiba; Paula Rocha e Elizabeth Cavalcante, do CPPL - Recife; Domingos Paulo Infante, Lina G. Martins de Oliveira e M. Cecília Casagrande, de São Paulo; Daniele Wanderley, de Salvador; Lea M. Sales, da Universidade Federal do Pará; Regina M. R. Stellin, da UNIFOR - Fortaleza; Flávia Dutra, de Brasília; Octavio Souza, da Fundação Oswaldo Cruz, do Rio de Janeiro; Silvia Molina do Centro Lydia Coriat - Porto Alegre; com coordenação técnica de M. Eugênia Pesaro, coordenação científica do Alfredo Jerusalinsky e coordenação nacional de Maria Cristina M. Kupfer, do IPUSP.

${ }^{4}$ O roteiro da Avaliação Psicanalítica aos 3 anos está publicado no livro: Lerner, R. e Kupfer, MCM. (orgs.) Psicanálise com crianças: clínica e pesquisa. 2008, 240p.
} 
como está se dando a interiorização da interdição paterna, como a "observância de limites, a restrição dos próprios impulsos em concordância com a situação, o reconhecimento da diferença de trato a desdobrar com pessoas estranhas ou familiares, a diferenciação de espaços e objetos de acordo com sua pertença e a permeabilidade do sujeito à marcação de tempos e atividades" Lerner e Kupfer, 2008, p. 128), a fala e a posição na linguagem (verifica-se se a criança entrou no campo da linguagem, "revelando sua possibilidade de se situar em relação às significações do mundo, sua possibilidade de sustentar as relações com os outros, de reconhecer na linguagem a demanda e o desejo dos outros, e de produzir, por sua vez, significações novas" 5 (Lerner \& Kupfer, 2008; Kupfer et al, 2009 e 2010).

A AP3 foi realizada com a sub-amostra de 280 crianças (158 consideradas casos e 122 do grupo controle) com a finalidade de estabelecer uma relação entre os indicadores do IRDI e o que eles evidenciavam das primeiras operações que tiveram em curso para a constituição subjetiva, e os efeitos manifestos - por meio de sintomas clínicos - a que essas operações deram lugar. Portanto, a partir dessas 280 avaliações foram levantados os sintomas clínicos apresentados pelas crianças e concluiu-se que o IRDI é um instrumento que não identifica a incidência de uma patologia específica, apenas indica a incidência de problemas de desenvolvimento (70,3\% da amostra) mais do que de riscos para a constituição do sujeito $(19,6 \%)$.

Entende-se como problemas de desenvolvimento a existência de dificuldades de ordem psíquica que causam "falhas de organização dos aspectos funcionais do desenvolvimento. Trata-se de crianças que não conseguem, por exemplo, ter um controle esfincteriamo, apesar de ter boas condições fisiológicas e maturacionais para tal; ou de crianças anoréxicas que desconcertam suas mães ao recusarem o que estas lhes oferecem para comer" (Bernadino, 2006, p.38). Quanto ao risco psíquico para a constituição do sujeito, foram selecionados sintomas considerados conclusivos capazes "de indicar não apenas dificuldades de ordem psíquica, mas principalmente por localizarem entraves no processo mesmo de constituição subjetiva e indicarem problemas mais estruturais, apontando um risco de evolução em direção às psicopatologias graves da infância, tais como os chamados distúrbios globais de desenvolvimento" (Kupfer et al., 2008, p. 223 e 224). Seguem no quadro 2, os sintomas clínicos, estabelecidos com as avaliações psicanalíticas - AP3:

\footnotetext{
${ }^{5}$ Kupfer et al, 2009, p.56.
} 
Quadro 2 - Sintomas clínicos e respectivos eixos teóricos.

\begin{tabular}{|c|c|c|}
\hline Eixos teóricos & 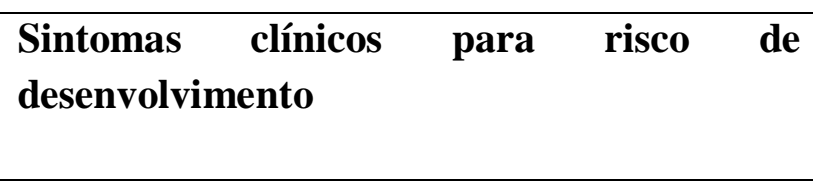 & $\begin{array}{l}\text { Sintomas clínicos conclusivos } \\
\text { considerados de grave risco } \\
\text { para a constituição subjetiva }\end{array}$ \\
\hline $\begin{array}{l}\text { I. O brincar e a } \\
\text { fantasia }\end{array}$ & $\begin{array}{l}\text { 1.Violência no brincar } \\
\text { 2.Ausência de enredo } \\
\text { 3.Inibição } \\
\text { 4.Inconstância } \\
\text { 5.Emergência de angústia ou medos durante o } \\
\text { brincar } \\
\text { 6.Falta de iniciativa, passividade e falta de } \\
\text { curiosidade } \\
\text { 7.Pobreza simbólica } \\
\text { 8.Recusa no brincar } \\
\text { 9.Ausência de faz de conta }\end{array}$ & $\begin{array}{l}\text { 1.Manipulação mecânica dos } \\
\text { brinquedos } \\
\text { 2.Atividade ou movimentos } \\
\text { repetitivos }\end{array}$ \\
\hline $\begin{array}{l}\text { II. O corpo e sua } \\
\text { imagem }\end{array}$ & $\begin{array}{l}\text { 1.Dificuldade no controle esfincteriano } \\
\text { 2.Agitação motora } \\
\text { 3.Atuações agressivas } \\
\text { 4.Ausência de reconhecimento de si como } \\
\text { menino ou menina } \\
\text { 5.Colagem no corpo da mãe } \\
\text { 6.Dificuldades alimentares (alimentação } \\
\text { seletiva, dificuldade alimentar não } \\
\text { especificada, obesidade, recusa do alimento) } \\
\text { 7.Dificuldades motoras } \\
\text { 8.Dificuldade de separação } \\
\text { 9.Doenças de repetição (amidalite, otite, } \\
\text { bronquite) } \\
\text { 10. Doenças psicossomáticas (alergias, asma, } \\
\text { dores inespecíficas) } \\
\text { 11.Exposição a perigos } \\
\text { 12.Demanda insistente do olhar do outro } \\
\text { 13.Passividade } \\
\text { 14.Falhas no reconhecimento de si no espelho } \\
\text { 15.Preocupação excessiva com a sujeira } \\
\text { 16.Alteração do sono } \\
\text { 17.Interrupção no crescimento } \\
\text { 18.Inibição diante do olhar do outro }\end{array}$ & $\begin{array}{l}\text { 1.Recusa de alimentação } \\
\text { sólida } \\
\text { 2.Impossibilidade de suportar } \\
\text { o olhar do outro } \\
\text { 3.Auto-agressão }\end{array}$ \\
\hline
\end{tabular}


Conclusão

\begin{tabular}{|c|c|c|}
\hline Eixos teóricos & $\begin{array}{l}\text { Sintomas clínicos } \\
\text { desenvolvimento }\end{array}$ & $\begin{array}{l}\text { Sintomas clínicos conclusivos } \\
\text { considerados de grave risco } \\
\text { para a constituição subjetiva }\end{array}$ \\
\hline $\begin{array}{l}\text { III.Manifestação } \\
\text { diante das normas e } \\
\text { posição frente à lei }\end{array}$ & $\begin{array}{l}\text { 1.Birras prolongadas } \\
\text { 2.Criança tem que ser castigada para obedecer } \\
\text { 3.Confusão e angústia frente à lei } \\
\text { 4.Desobediência desafiadora } \\
\text { 5.Conhece os limites mas não os respeita } \\
\text { 6.Criação de medos substitutivos da lei } \\
\text { 7.Negativismo }\end{array}$ & $\begin{array}{l}\text { 1.Recusa da presença do } \\
\text { terceiro } \\
\text { 2.Recusa do não } \\
\text { 3.Submissão excessiva à lei }\end{array}$ \\
\hline $\begin{array}{l}\text { IV. Fala e posição na } \\
\text { linguagem }\end{array}$ & $\begin{array}{l}\text { 1.Troca de letras ou sílabas na fala } \\
\text { 2.Fala infantilizada } \\
\text { 3.Linguagem incompreensível com tentativa } \\
\text { de interlocução } \\
\text { 4.Pobreza expressiva } \\
\text { 5.Pobreza de vocabulário } \\
\text { 6.Fala traduzida pelo cuidador } \\
\text { 7.Inibição }\end{array}$ & $\begin{array}{l}\text { 1.Ausência de pronomes } \\
\text { pessoais } \\
\text { 2.Repetição ecolálica } \\
\text { 3.Linguagem incompreensível } \\
\text { sem busca de interlocução } \\
\text { 4.Uso da terceira pessoa para } \\
\text { referir-se a si mesmo } \\
\text { 5.Não forma frases (pobreza } \\
\text { simbólica) }\end{array}$ \\
\hline
\end{tabular}

Fonte: adaptado pela pesquisadora de Lerner e Kupfer, 2008, p.146 e 147.

Foram feitas comparações entre os indicadores ausentes do IRDI e os resultados da AP3 dos 2 grupos e estabeleceu-se o valor preditivo de cada indicador, a partir da análise de covariância que indica o risco relativo aos três anos. (Lerner \& Kupfer 2008; Kupfer et al, 2009 e 2010)

A análise estatística demonstrou que o IRDI apresenta maior capacidade de predizer risco para o desenvolvimento do que risco para a constituição subjetiva e elegeu indicadores isolados e em grupos fatoriais capazes de indicar os dois diferentes tipos de risco, apresentados nas tabelas a seguir: 
Tabela 1 - Indicadores isolados capazes de predição de risco psíquico e de problemas de desenvolvimento.

\begin{tabular}{|c|c|c|c|}
\hline Indicadores isolados & $\begin{array}{l}\text { Faixas em } \\
\text { meses }\end{array}$ & $\begin{array}{l}\text { Risco } \\
\text { relativo }\end{array}$ & $\begin{array}{l}\text { Intervalo de } \\
\text { confiança } 95 \%\end{array}$ \\
\hline \multicolumn{4}{|l|}{ Risco para a constituição psíquica } \\
\hline $\begin{array}{l}\text { 7. A criança utiliza sinais diferentes para expressar } \\
\text { suas diferentes necessidades }\end{array}$ & 4 a 8 & 3,46 & $1,19-10,07$ \\
\hline 18. A criança estranha pessoas desconhecidas para ela & 8 a 12 & 2,93 & $1,49-5,73$ \\
\hline $\begin{array}{l}\text { 22. A criança aceita alimentação semi-sólida, sólida e } \\
\text { variada }\end{array}$ & 8 a 12 & 3,75 & $1,37-10,28$ \\
\hline $\begin{array}{l}\text { 30. Os pais colocam pequenas regras de } \\
\text { comportamento para a criança }\end{array}$ & 12 a 18 & 4,19 & $1,74-10,06$ \\
\hline \multicolumn{4}{|l|}{ Risco para problemas de desenvolvimento } \\
\hline $\begin{array}{l}\text { 24. A criança suporta bem as breves ausências da mãe } \\
\text { e reage às ausências prolongadas }\end{array}$ & 12 a 18 & 2,83 & $1,26-6,35$ \\
\hline $\begin{array}{l}\text { 26. A mãe já não se sente mais obrigada a satisfazer } \\
\text { tudo que a criança pede }\end{array}$ & 12 a 18 & 3,01 & $1,11-8,14$ \\
\hline
\end{tabular}

Fonte: adaptação da tabela publicada em Kupfer et al., 2009, p.58.

Tabela 2 - Conjuntos de indicadores que tiveram correlação significante para predizer risco para a constituição psíquica e risco de problemas de desenvolvimento.

\begin{tabular}{llll}
\hline Conjuntos de indicadores, após análise fatorial & $\begin{array}{l}\text { Faixas em } \\
\text { meses }\end{array}$ & $\begin{array}{l}\text { Risco } \\
\text { relativo }\end{array}$ & $\begin{array}{l}\text { Intervalo } \\
\text { confiança 95\% }\end{array}$ \\
\hline Risco para a constituição psíquica & & & \\
\hline $\begin{array}{l}\text { d, 2, 3, 4 e 5 } \\
\text { 6, 7, 8, 9 }\end{array}$ & 0 a 4 & 3,51 & $1,10-11,17$ \\
16 e 22 & 8 a 12 & 2,50 & $1,01-6,59$ \\
23, 24, 26 e 30 & 12 a 18 & 1,99 & $1,97-13,15$ \\
Risco para problemas de desenvolvimento & & & \\
23, 24, 26 e 30 & 12 a 18 & 2,82 & $1,45-5,45$ \\
\hline
\end{tabular}

Fonte: tabela criada pela autora a partir de dados publicados em Lerner e Kupfer, 2008, p.226.

Além de o tratamento estatístico indicar os riscos relativos, o uso do IRDI se justifica também pela sua possibilidade de ser uma "leitura" - como dizia Cristina Kupfer em uma de suas aulas sobre o protocolo - da constituição subjetiva e exige uma postura do aplicador. Mais do que marcar se o indicador está presente ou ausente, se faz necessária uma abertura para a singularidade/subjetividade e para o contato com o outro. Há uma convocação de sujeitos, tanto de quem avalia, como de quem está sendo avaliado. 
Quando isso é possível, o IRDI também é um parâmetro qualitativo do desenvolvimento emocional de bebês e por isso contribui para um refinamento dessa prática, prestando-se mais como um instrumento de intervenção que ainda pode possibilitar a promoção de saúde.

\subsection{Por onde tem andado?}

Durante a pesquisa IRDI, o manual de normas técnicas para avaliação do desenvolvimento infantil: Saúde da criança - acompanhamento do crescimento e desenvolvimento infantil foi reeditado pelo Ministério da Saúde (2002) e incluiu vários aspectos sobre o desenvolvimento psíquico do bebê e alguns indicadores do protocolo. Há ainda enfoque no vínculo mãe-bebê como medida de promoção de saúde mental e prevenção de distúrbios psíquicos. Após a validação do IRDI, outros indicadores seriam incorporados a esse material. No entanto, sua nova edição ainda não foi realizada.

Em 2005, a Área Técnica de Saúde da Criança e Aleitamento Materno do Ministério da Saúde realizou uma revisão no cartão da criança, transformando-o na Cardeneta de Saúde da Criança, com o objetivo de promover a vigilância à saúde da criança. A caderneta é disponibilizada ainda na maternidade pelo Governo Federal a todos os bebês e auxilia as famílias e os profissionais a acompanhar a saúde, o crescimento e o desenvolvimento do recém-nascido até os 10 anos de idade. Esse material é editado periodicamente e seu conteúdo oscila um pouco, principalmente quanto aos aspectos do desenvolvimento, mas basicamente é possível dividi-lo em duas partes: uma mais explicativa sobre direitos dos pais e da criança, amamentação, saúde bucal, saúde auditiva e ocular, vacinas, vitaminas e aspectos do desenvolvimento neuromotor, para orientar os pais e outra para ser usada por profissionais de saúde, contendo gráficos para registros sobre crescimento do bebê e vacinas administradas.

As cadernetas estão disponíveis online e foi possível verificar que a edição de 2007 apresenta orientações, nomeadas de desenvolvendo-se com afeto, aos pais de como se relacionarem com seus filhos, baseadas nas 4 faixas dos indicadores e nos seus fundamentos. Tata-se de um uso educativo do IRDI, muito mais voltado para orientar os pais do que os profissionais de saúde. 
Além de incluir os marcos do desenvolvimento neuropsicomotor e orientações quanto aos riscos de acidentes, parte intitulada de desenvolvendo-se com segurança.

A última caderneta encontrada foi editada em 2011 e ainda contém informações para os pais orientadas pelo IRDI e suas concepções. Quanto à parte utilizada pelos profissionais, há menção aos sinais do autismo, provavelmente referenciados por manuais psiquiátricos. Parece que atualmente a concepção de desenvolvimento que orienta as edições da caderneta se baseia mais em dados fenomênicos, distanciando-se novamente da singularidade. Para que efetivamente tenhamos políticas públicas que considerem o IRDI, dependeremos do quanto o sujeito psíquico poderá ser incorporado nas práticas de saúde.

Embora o IRDI não tenha sido integralmente incorporado nas práticas de saúde através da cardeneta de saúde da criança, sabemos que alguns centros participantes da pesquisa multicêntrica ainda o utilizam nos serviços de saúde como uma iniciativa própria, sem contar com dimensões amplas de políticas públicas. Estudos com o IRDI continuam a ser realizados em diferentes áreas do conhecimento e em diversas regiões do Brasil, principalmente nas cidades que participaram da pesquisa multicêntrica. As articulações do protocolo com a educação, a saúde coletiva e a saúde mental têm sido bastante relevantes nas pesquisas atuais.

Carvalho, Silva, Grisi e Escobar, (2008) analisaram a influência dos fatores culturais regionais sobre o desenvolvimento psíquico das crianças acompanhadas pela pesquisa multicêntrica. Bento, Silva e Grisi (2008) também se basearam no banco de dados da pesquisa para verificar o impacto da escolaridade e da idade materna no desenvolvimento psíquico das crianças.

Com objetivo de verificar crianças em riscos de desenvolvimento no contexto educacional, Marriotto (2007) adaptou o IRDI para ser aplicado em crianças inseridas em 2 creches de Curitiba e concluiu a aplicabilidade e a possível extensão do protocolo para a educação infantil.

Bernadino, Vaz, Quadros e Vaz (2008) articularam as áreas da psicanálise com crianças e educação, com o uso do IRDI, utilizando-o em dois berçários de uma creche em Curitiba para analisar possíveis riscos para a constituição subjetiva e a qualidade da relação estabelecida entre educadoras e bebês. Concluiu-se que as educadoras nem sempre conseguiam desempenhar as funções necessárias para propiciar a constituição do psiquismo dos bebês cuidados. 
Também na articulação da educação com a psicanálise, Kupfer (2011) tem acompanhado a constituição subjetiva de bebês de creches com a metodologia IRDI e vem transformando-o "em referência para um conjunto de ações a serem desenvolvidas em instituições de educação infantil" (p.15).

Pesaro (2009) aprofundou a fundamentação teórica do IRDI, considerando cada indicador e seu respectivo eixo e discutiu interlocuções entre os métodos experimental e clínico, inerentes ao IRDI.

Di Paolo (2010) avaliou 46 crianças, que na ocasião estavam com 6 anos, com os instrumentos Autoquestionnaire Qualité de Vie Enfant Imagé - AUQUEI, Child Health Questionnaire - CHQ e Child Behavioral Checklist - CBCL. Essas crianças haviam participado da pesquisa multicêntrica do IRDI, portanto, já tinham sido acompanhadas até 18 meses com IRDI e aos 3 anos com AP3. Foi realizado um estudo exploratório com o objetivo de verificar em que medida resultados referentes a condições psíquicas e de desenvolvimento obtidos com a aplicação do IRDI e da AP3 associam-se com resultados referentes à qualidade de vida e à condição sintomática da criança aos 6 anos, obtidos com o uso dos instrumentos atuais. Verificou-se que há capacidade estatisticamente significativa do IRDI, aplicado nos 18 meses de vida, para predizer qualidade de vida relacionada ao índice psicossocial aos seis anos, sendo o IRDI capaz de detectar uma tendência de ocorrência de problemas iniciais que podem se estender ao longo do desenvolvimento da criança pelo menos até o sexto ano.

Lerner (2011) verificou a capacidade discriminativa do IRDI entre autismo, retardo mental e normalidade em um estudo com vídeos caseiros de bebês de até 18 meses, utilizando além do IRDI, os instrumentos Questionário do Desenvolvimento da Comunicação - QDC e o conjunto de sinais PREAUT. Concluiu-se que os indicadores 5, 10, 16, 29 e 30 e os QDCs 3 e 6 tiveram capacidade discriminativa estatisticamente significativa entre as patologias vistas e a normalidade. Foi sugerida, pelo autor, a inclusão de itens dos instrumentos com capacidade discriminativa para autismo em pesquisas sobre detecção dessa natureza. Foi devido a essa pesquisa que incluimos no protocolo IRDI, utilizado pelas profissionais de enfermagem, os QDC 3 e 6. Esta pesquisa insere-se num grupo que tem como um dos objetivos verificar se itens do IRDI são capazes de detectar sinais iniciais de autismo. Dados oriundos da aplicação do instrumento no escopo do presente trabalho servem ao objetivo acima mencionado. 
Machado (2012) tem adaptado o IRDI para ser utilizado retrospectivamente com pais de crianças já diagnosticadas autistas, além de apresentar uma perspectiva do IRDI para profissionais da área fonoaudiológica, expandindo ainda mais seu uso.

Campana (2012) fez um acompanhamento longitudinal de bebês utilizando o IRDI seguido da aplicação do Modified Checklist for Autism in Toddlers - M-CHAT, instrumento desenvolvido para identificar crianças com autismo a partir dos 18 meses de vida. Considerando os resultados no M-CHAT, propõe-se verificar se o IRDI aponta crianças com certo grau de manifestação clínica da referida patologia. Conclui-se que há maior risco nas crianças com muitos indicadores ausentes relacionados ao eixo estabelecimento da demanda.

\subsection{Para onde fomos, nesse trabalho?}

Desde a idealização do IRDI há uma expectativa de que seja usado por profissionais de saúde originalmente, pediatras - e a favor da saúde coletiva. Foi considerando esse clima que realizamos uma formação longitudinal do IRDI com enfermeiros, auxiliares de enfermagem e agentes comunitários de saúde. Nesse trabalho, analisaremos os dados referentes aos enfermeiros e auxiliares de enfermagem. Quanto à formação com agentes comunitários de saúde, a mestranda Ana Silvia de Morais, também do IPUSP, tem discutido os dados em sua dissertação.

Os profissionais de enfermagem já acompanham longitudinalmente o bebê em suas rotinas e, especificamente no município de Embu das Artes, há um protocolo em que bebês de baixo risco são vistos nos seguintes períodos de vida: 15 dias, 2 meses, 4, 8, 10 e 15 meses, e portanto, a ideia de formar os profissionais de enfermagem foi devida à ampla exposição a essa população. Intuimos que, como esses profissionais têm bastante contato com bebês, provavelmente estão mais abertos e sensibilizados para acompanhá-los longitudionalmente.

Além desses aspectos práticos apresentados, a entrada do IRDI em serviços de saúde e seu uso por profissionais da área justifica-se, principalmente, por expor a um exercício de que se considere a subjetividade da população assistida. A própria construção do IRDI veio ao encontro da tendência de colocar em cena as particularidades do sujeito; já que na área da saúde, entende- 
se que haja uma inclinação contrária, justamente de valorizar características biológicas do individuo determinando práticas em saúde por essa via. (Silva et al., 2004; Souza, Alencastre, \& Saeki, 2000). Portanto, a formação teve o intuito de sensibilizar os profissionais de enfermagem para área psicológica do desenvolvimento infantil. 
3. Objetivos 
O objetivo principal desta pesquisa é verificar a apreensão de conhecimento e a aprendizagem de profissionais de enfermagem da atenção básica à saúde, a partir de uma ação em educação permanente com Indicadores Clínicos de Risco para o Desenvolvimento Infantil - IRDI.

\subsection{Objetivos específicos}

- Analisar em que medida os profissionais de enfermagem se apropriam dos fundamentos do IRDI e do aspecto relacional existente entre os bebês e suas famílias;

- Verificar como esses profissionais realizam a proposta de acompanhar a população infantil nas Unidades Básicas de Saúde com o uso do IRDI. 
4. Método 
Minayo (2010), ao problematizar o uso de métodos quantitativos e qualitativos em pesquisas de saúde, aborda algumas limitações encontradas em ambos. Utilizando o método quantitativo, corremos o risco de reduzir a realidade em quantidades e frequências sem considerar o contexto e as particularidades nela envolvidas; o método qualitativo também pode ser apresentado dentro de uma perspectiva reducionista quando se obtém uma percepção simplista e incompleta do fenômeno. Basta assumirmos os riscos e as limitações inerentes aos métodos de pesquisa, seja para qual lado formos. Mais do que atribuir prioridade de um sobre o outro, a autora cita modelos, como a dialética marxista, que trazem a ideia de que "quantidade e qualidade são inseparáveis e interdependentes" (p. 25).

Como afirma a autora, o "conhecimento é infinito" (p. 34) e quando estabelecemos o recorte de pesquisa, que por sua vez implica o método a ser utilizado, estamos delimitando e construindo um conjunto de ideias que só fazem sentido dentro de si. Como explicitado por Lerner (2008), na apresentação do livro Psicanálise com crianças: clínica e pesquisa, o método é o encadeamento coerente entre 3 elementos: um objeto, uma pergunta e formas de respostas obtidas, que formam um conjunto de ideias fundamentais (uma teoria) e levam a um ou mais procedimentos.

A partir das ideias de Minayo e Lerner, podemos considerar que o que justifica o método utilizado é a própria natureza da pergunta e do objeto estudado e, portanto, a complexidade do que se busca saber. A articulação entre métodos quantitativos e qualitativos não é nada extraordinária quando "há possibilidade de se analisarem regularidades, frequências, mas também relações, histórias, representações, pontos de vista e lógica interna dos sujeitos em ação”, como ocorre com os fenômenos sociais (Minayo, 2010, p. 63).

Como analisamos efeitos de intervenção em educação permanente e alguns sentidos atribuídos ao uso de um protocolo de saúde do bebê, estabelecemos nesse estudo a articulação entre os métodos quantitativos e qualitativos. A articulação de métodos representa avanços para a compreensão de problemas de saúde: "mais que pares de oposições, os métodos quantitativos e qualitativos traduzem, cada qual à sua maneira, as articulações entre o singular, o individual e o coletivo presentes nos processos de saúde-doença” (Minayo, 2010, p. 75).

Portanto, exploramos os dados oriundos de perguntas realizadas na forma de fichas respondidas pelos sujeitos, de maneira que pudemos gerar frequências e percentagens quanto ao 
conhecimento adquirido e também realizamos uma análise qualitativa dos mesmos. Além do mais, executamos uma análise qualitativa a partir de experiências das participantes ao passarem pela monitoria ao utilizarem o IRDI.

\subsection{Estratégias para intervenção em educação permanente}

Considerando os objetivos propostos nessa pesquisa, realizamos algumas estratégias formativas em educação permanente e outras para coleta de dados, conforme resumido no Cronograma da Formação IRDI e da Coleta de Dados, apresentado na página seguinte. Como ações em educação permanente, tivemos:

1-Quatro encontros de formação ao longo do ano de 2011 para profissionais de enfermagem da atenção básica. $\mathrm{O}$ curso abordou aspectos relacionais do desenvolvimento infantil e sinais iniciais de problemas de desenvolvimento através do protocolo IRDI;

2-Utilização do IRDI pelos profissionais formados, durante usuais atuações nas unidades básicas de saúde;

3-Monitorias em serviço realizadas pela pesquisadora, dando continuidade à formação, de forma de manter o vínculo transferencial com os profissionais, possibilitando maior apropriação dos itens do protocolo e do aspecto relacional do desenvolvimento infantil. 


\section{CRONOGRAMA DA FORMACÃO IRDI E COLETA DE DADOS}

Preenchimento, pelos profissionais do grupo pré intervenção, da $1^{1^{a}}$ ficha de acompanhamento (ficha 1)

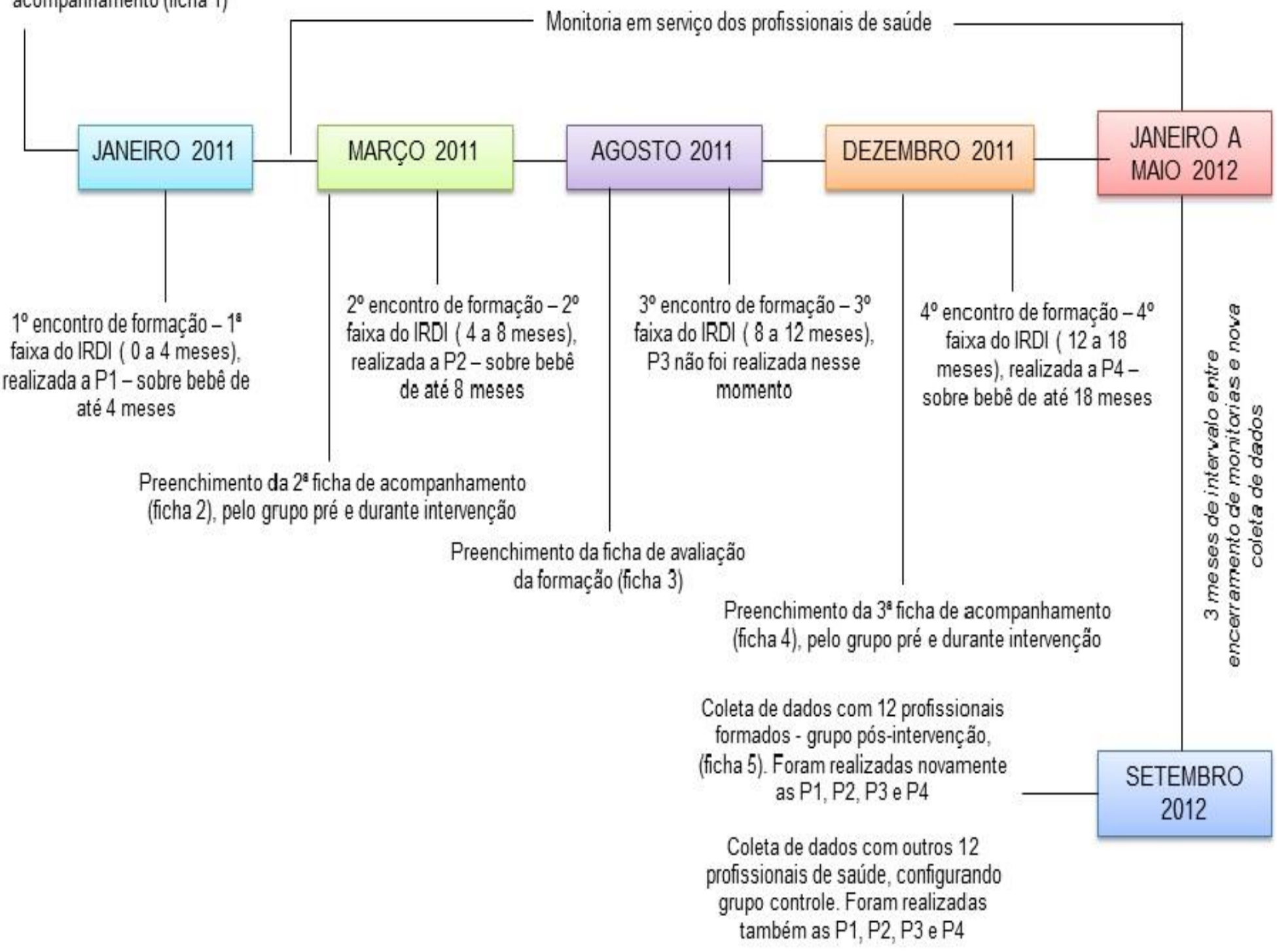




\subsection{Os quatro encontros formativos}

Uma das estratégias de educação permanente para o uso do IRDI foi a realização de encontros de formação, que foram divididos em 4 encontros ao longo de 2011, propiciando que as faixas do protocolo fossem aplicadas nos bebês assistidos conforme o material dado. Teve início em janeiro, abordando a primeira etapa do protocolo, de 0-4 meses incompletos de idade do bebê; em março, no segundo encontro, trabalhamos a faixa de 4-8 meses; em agosto, no terceiro, a faixa etária de 8-12 meses incompletos, e em dezembro, a formação foi finalizada com a quarta faixa do protocolo, de 12-18 meses.

Participaram da formação 130 profissionais de saúde dentre enfermeiros, auxiliares de enfermagem, agentes comunitários de saúde e pessoas de cargos administrativos. No entanto, este trabalho tem como recorte para análise apenas a participação de enfermeiros e auxiliares de enfermagem.

Considerando que tínhamos como objetivo principal a aproximação dos profissionais de saúde dos pacientes bebês e suas famílias utilizando o IRDI com o intuito de sensibilizá-los para a subjetividade infantil, marcamos os encontros de formação com aspectos subjetivos dos próprios profissionais de enfermagem; permitimos e incentivamos que falassem de seus sentimentos e de suas histórias pessoais.

No primeiro encontro, realizado no Instituto de Psicologia da Universidade de São Paulo, tivemos alguns cuidados para que os profissionais fossem acolhidos, sem que se sentissem intimidados. Para tanto, tivemos a preocupação de não iniciarmos com aula expositiva para que não se estabelecesse uma relação hierarquizada de professor, tido como detentor do conhecimento, e alunos, submetidos ao mesmo.

Com o objetivo de propor uma discussão menos técnica e mais próxima da experiência dos participantes, além de considerar os conhecimentos prévios de cada um, incentivamos a participação ativa dos profissionais na formação. Realizamos uma discussão em pequenos grupos sobre as experiências de cada um com bebês, tendo como questões norteadoras: $\mathrm{O}$ que um bebê mobiliza nos adultos que cuidam dele? $\mathrm{O}$ que um adulto pode provocar no bebê? 
Depois do primeiro encontro, visitamos todos os centros participantes da pesquisa e buscamos ouvir as impressões dos profissionais sobre o primeiro encontro. A grande maioria se queixou da estrutura do curso, relatando suas expectativas. Esperavam aprender sobre o diagnóstico de autismo; sobre o desenvolvimento infantil, a partir de uma perspectiva orgânica - inclusive gostariam de rever os marcos do desenvolvimento; esperavam também um curso com aulas expositivas, incluindo recursos audiovisuais. A estratégia de evitarmos um modelo que tamponasse o saber dos participantes parece ter tido efeitos positivos, como o engajamento dos participantes e a demanda por tópicos informativos.

Considerando isso, estruturamos o segundo encontro para esclarecer, em alguma medida, os conteúdos demandados. Discutimos sobre autismo e desenvolvimento infantil, levando em conta a articulação entre características orgânicas e relacionais. Nesse encontro, sentimos também a necessidade de reforçar alguns assuntos que evidenciassem a relação entre o uso do protocolo IRDI e suas finalidades. Assim, explicamos que embora o IRDI seja inespecífico para diagnósticos, é um protocolo que tem capacidade de detectar riscos para problemas de desenvolvimento, indicando os riscos relativos de cada indicador. Reforçamos também que com o IRDI podemos acompanhar o desenvolvimento infantil em suas minúcias e seguir as sutilezas implicadas nas relações humanas, nesse caso, a relação entre mãe/cuidador e bebê. Elucidamos ainda a importância do protocolo IRDI e seus benefícios para a saúde pública, para os profissionais e para as crianças acompanhadas. Acreditamos que abordar tais temas evidenciou os objetivos do IRDI e as funções dos participantes e provavelmente proporcionou maior atribuição de sentido para a utilização do protocolo.

Apesar de esse encontro ter se caracterizado mais como uma aula expositiva (o que foi evitado no primeiro encontro), os profissionais estiveram à vontade, fizeram perguntas e comentários, interrompendo o Prof. Rogério - que conduziu o encontro e sempre deixou espaço para participações.

No terceiro e quarto encontro, estabelecemos um espaço de interlocução em que os participantes pudessem falar sobre dúvidas, experiências referentes à assistência, vivências pessoais, sugestões, entre outros. Com o intuito de proporcionar maior apropriação dos indicadores, os participantes foram divididos em grupos onde foram discutidos dois indicadores por grupo, de modo que eles pudessem explorar o entendimento de cada item e relacioná-los com exemplos do cotidiano, 
evocando experiências próprias quanto ao aspecto tratado. Poderiam propor também uma modificação no enunciado e na descrição do indicador.

Assim, o curso de formação baseou-se em diferentes maneiras de sensibilização. Propôs uma articulação que evocasse sentimentos com relação a cuidar de bebês, conhecimentos prévios dos profissionais, bem como relatos de experiências pessoais, permitindo que os mesmos fizessem parte do processo. Segue apresentação resumida dos 4 encontros:

Quadro 3 - Características dos 4 encontros formativos.

\begin{tabular}{|c|c|c|c|c|}
\hline Características & $1^{\circ}$ encontro & $2^{\circ}$ encontro & $3^{\circ}$ encontro & $4^{\circ}$ encontro \\
\hline $\begin{array}{l}\text { Objetivos do } \\
\text { encontro }\end{array}$ & $\begin{array}{c}\text { Sensibilizar os } \\
\text { profissionais de saúde } \\
\text { para aspectos } \\
\text { psicológicos do } \\
\text { desenvolvimento infantil } \\
\text { Discutir experiências } \\
\text { pessoais com bebês: o } \\
\text { que um bebê provoca/ } \\
\text { mobiliza nos adultos que } \\
\text { cuidam dele? O que um } \\
\text { adulto pode provocar no } \\
\text { bebê? }\end{array}$ & $\begin{array}{l}\text { Aproximar a proposta da } \\
\text { formação da demanda dos } \\
\text { participantes } \\
\text { Reafirmar a importância } \\
\text { do protocolo e atribuir } \\
\text { sentido ao seu uso } \\
\text { Explicar a capacidade do } \\
\text { IRDI em identificar sinais } \\
\text { de riscos para o } \\
\text { desenvolvimento e } \\
\text { problemas mais graves, } \\
\text { como o autismo }\end{array}$ & $\begin{array}{c}\text { Construir um espaço para } \\
\text { falas dos participantes - } \\
\text { dúvidas, troca de } \\
\text { experiências, críticas, } \\
\text { sugestões } \\
\text { Retomar aspectos } \\
\text { psicológicos do } \\
\text { desenvolvimento infantil } \\
\text { Exercício de apropriação } \\
\text { dos indicadores da } 3^{\mathrm{a}} \\
\text { faixa, elegendo exemplos } \\
\text { do cotidiano vivenciados } \\
\text { pelos participantes }\end{array}$ & $\begin{array}{c}\text { Manter o espaço de } \\
\text { interlocução para relatos } \\
\text { de dúvidas, troca de } \\
\text { experiências, críticas, } \\
\text { sugestões } \\
\text { Exercício de apropriação } \\
\text { dos indicadores da } 4^{\mathrm{a}} \text { faixa, } \\
\text { elegendo exemplos do } \\
\text { cotidiano vivenciados } \\
\text { pelos participantes }\end{array}$ \\
\hline $\begin{array}{c}\text { Tópicos } \\
\text { abordados }\end{array}$ & $\begin{array}{l}\text { Introdução ao aspecto } \\
\text { relacional do } \\
\text { desenvolvimento infantil } \\
\text { Fundamentos do IRDI } \\
\text { Apresentação dos } \\
\text { indicadores da } 1^{\mathrm{a}} \text { faixa } \\
\text { do protocolo }\end{array}$ & $\begin{array}{c}\text { Apresentação dos } \\
\text { indicadores da } 2^{\text {a }} \text { faixa } \\
\text { Explorar como o } \\
\text { profissional avaliaria cada } \\
\text { indicador e como ele o } \\
\text { transmitiria para alguém, } \\
\text { objetivando maior } \\
\text { apropriação do protocolo }\end{array}$ & $\begin{array}{c}\text { Relatos de experiências } \\
\text { dos profissionais quanto à } \\
\text { assistência e vivências fora } \\
\text { dela } \\
\text { Apresentação dos } \\
\text { indicadores da } 3^{\text {a }} \text { faixa } \\
\text { Explorar como o } \\
\text { profissional avaliaria cada } \\
\text { indicador e como ele o } \\
\text { transmitiria para alguém, } \\
\text { objetivando maior } \\
\text { apropriação do protocolo }\end{array}$ & $\begin{array}{c}\text { Exigência de uma } \\
\text { investigação por inquérito, } \\
\text { devido características da } \\
\text { criança } \\
\text { Apresentação dos itens da } \\
4^{\text {a } \text { faixa }} \\
\text { Explorar como o } \\
\text { profissional avaliaria cada } \\
\text { indicador e como ele o } \\
\text { transmitiria para alguém, } \\
\text { objetivando maior } \\
\text { apropriação do protocolo } \\
\text { Solicitar sugestões dos } \\
\text { profissionais para } \\
\text { incorporação do IRDI na } \\
\text { assistência }\end{array}$ \\
\hline
\end{tabular}

Continua 


\section{Continuação}

\begin{tabular}{|c|c|c|c|c|}
\hline Características & $1^{\circ}$ encontro & $2^{\circ}$ encontro & $3^{\circ}$ encontro & $4^{\circ}$ encontro \\
\hline $\begin{array}{l}\text { Método } \\
\text { utilizado }\end{array}$ & $\begin{array}{l}\text { Discussão em pequenos } \\
\text { grupos sobre ser e estar } \\
\text { com bebês } \\
\text { Apresentação do que foi } \\
\text { discutido nos grupos } \\
\text { Aula expositiva dada } \\
\text { pelo coordenador do } \\
\text { curso }\end{array}$ & $\begin{array}{l}\text { Aula expositiva dada pelo } \\
\text { coordenador do curso } \\
\text { Apresentação dos vídeos } \\
\text { com indicadores da } 2^{\mathrm{a}} \\
\text { faixa, estimulando os } \\
\text { participantes a expor } \\
\text { situações e exemplos do } \\
\text { cotidiano relacionados a } \\
\text { cada indicador, na } \\
\text { sequência: explicações do } \\
\text { coordenador }\end{array}$ & $\begin{array}{l}\text { Aula expositiva dada pelo } \\
\text { coordenador do curso } \\
\text { Trabalho em pequenos } \\
\text { grupos sobre } 2 \text { indicadores } \\
\text { da faixa tratada para } \\
\text { explorar o entendimento } \\
\text { do item e contribuir com } \\
\text { exemplos do cotidiano, } \\
\text { com seguintes perguntas: } \\
\text { O que entendem por isso? } \\
\text { Como explicariam? Em } \\
\text { que situações verificam } \\
\text { isso? } \\
\text { Apresentação da discussão } \\
\text { em grupo para todos } \\
\text { participantes } \\
\text { Apresentação dos vídeos } \\
\text { ilustrando cada indicador, } \\
\text { seguida de explicações do } \\
\text { coordenador }\end{array}$ & $\begin{array}{l}\text { Trabalho em pequenos } \\
\text { grupos sobre } 2 \text { indicadores } \\
\text { da faixa tratada para } \\
\text { explorar o entendimento } \\
\text { do item e contribuir com } \\
\text { exemplos do cotidiano, } \\
\text { com seguintes perguntas: } \\
\text { O que entendem por isso? } \\
\text { Como explicariam? Em } \\
\text { que situações verificam } \\
\text { isso? } \\
\text { Apresentação da discussão } \\
\text { em grupo para todos } \\
\text { Apresentação dos vídeos } \\
\text { ilustrando cada indicador, } \\
\text { seguida de explicações do } \\
\text { coordenador }\end{array}$ \\
\hline $\begin{array}{c}\text { Materiais } \\
\text { distribuídos }\end{array}$ & $\begin{array}{c}1^{\text {a }} \text { Ficha de } \\
\text { acompanhamento sobre } \\
\text { conhecimentos prévios e } \\
\text { a prática do profissional } \\
\text { com bebês (entregue } 15 \\
\text { dias antes e recolhida no } \\
\text { dia do encontro) } \\
\text { Breve apostila } \\
\text { explicativa sobre } \\
\text { utilização e } \\
\text { fundamentação do } \\
\text { protocolo, bem como } \\
\text { descrição dos } 5 \text { primeiros } \\
\text { itens, relativos à } 1^{\mathrm{a}} \text { faixa } \\
\text { (0 a } 4 \text { meses) } \\
\text { Termos de } \\
\text { consentimento livre e } \\
\text { esclarecido e protocolos } \\
\text { IRDI da faixa de } 0 \text { a } 4 \\
\text { meses para aplicação } \\
\text { pelos profissionais }\end{array}$ & $\begin{array}{c}2^{\text {a }} \text { Ficha de } \\
\text { acompanhamento sobre } \\
\text { conhecimentos prévios e a } \\
\text { prática do profissional com } \\
\text { bebês (entregue e recolhida } \\
\text { no dia do encontro) } \\
\text { Breve apostila com } \\
\text { descrição dos } 8 \text { itens, } \\
\text { relativos à } 2^{\text {a }} \text { faixa (4 a } 8 \\
\text { meses) } \\
\text { Protocolos IRDI da faixa } \\
\text { de } 4 \text { a } 8 \text { meses para } \\
\text { aplicação pelos } \\
\text { profissionais }\end{array}$ & $\begin{array}{c}\text { Ficha de avaliação da } \\
\text { formação para investigar } \\
\text { as desistências (entregue } \\
15 \text { dias antes e recolhida } \\
\text { no dia do encontro) } \\
\text { Breve apostila com } \\
\text { descrição dos } 9 \text { itens, } \\
\text { relativos à } 3^{\text {a }} \text { faixa ( } 8 \text { a } 12 \\
\text { meses) } \\
\text { Protocolos IRDI da faixa } \\
\text { de } 8 \text { a } 12 \text { meses para } \\
\text { aplicação pelos } \\
\text { profissionais }\end{array}$ & $\begin{array}{c}4^{\text {a }} \text { Ficha de } \\
\text { acompanhamento sobre } \\
\text { conhecimentos prévios e a } \\
\text { prática do profissional com } \\
\text { bebês (entregue e recolhida } \\
\text { no dia do encontro) } \\
\text { Breve apostila com } \\
\text { descrição dos } 9 \text { itens, } \\
\text { relativos à } 4^{\text {a }} \text { faixa (12 a } 18 \\
\text { meses) } \\
\text { Protocolos IRDI da faixa } \\
\text { de } 12 \text { a } 18 \text { meses para } \\
\text { aplicação pelos } \\
\text { profissionais }\end{array}$ \\
\hline
\end{tabular}

Continua 
Conclusão

\begin{tabular}{|c|c|c|c|c|}
\hline Características & $1^{\circ}$ encontro & $2^{\circ}$ encontro & $3^{\circ}$ encontro & $4^{\circ}$ encontro \\
\hline $\begin{array}{c}\text { Equipe } \\
\text { organizadora }\end{array}$ & $\begin{array}{l}\text { Prof. Rogério Lerner, } \\
\text { Andrea Tocchio e Ana } \\
\text { Silvia de Morais }{ }^{8}\end{array}$ & $\begin{array}{l}\text { Prof. Rogério Lerner, } \\
\text { Andrea Tocchio e Ana } \\
\text { Silvia de Morais }\end{array}$ & $\begin{array}{l}\text { Prof. Rogério Lerner, } \\
\text { Andrea Tocchio e Ana } \\
\text { Silvia de Morais }\end{array}$ & $\begin{array}{c}\text { Prof. Rogério Lerner, } \\
\text { Andrea Tocchio e Ana } \\
\text { Silvia de Morais }\end{array}$ \\
\hline $\begin{array}{l}\text { Coordenador e } \\
\text { ministrante }\end{array}$ & Prof. Rogério Lerner & Prof. Rogério Lerner & Prof. Rogério Lerner & Prof. Rogério Lerner \\
\hline Duração & 4 horas & 4 horas & 4 horas & 4 horas \\
\hline Data & $29-01-2011$ & $18-03-2011$ & $05-08-2011$ & $16-12-2011$ \\
\hline Local & $\begin{array}{c}\text { Instituto de Psicologia da } \\
\text { Universidade de São } \\
\text { Paulo - IPUSP, Campus } \\
\text { Capital }\end{array}$ & $\begin{array}{c}\text { Centro Cultural Parque } \\
\text { Pirajuçara, Embu das Artes }\end{array}$ & $\begin{array}{c}\text { Centro Cultural Parque } \\
\text { Pirajuçara, Embu das Artes }\end{array}$ & $\begin{array}{c}\text { Centro Cultural Parque } \\
\text { Pirajuçara, Embu das Artes }\end{array}$ \\
\hline $\begin{array}{c}\mathrm{N}^{\mathrm{o}} \mathrm{de} \\
\text { participantes }\end{array}$ & $\begin{array}{l}29 \text { auxiliares de } \\
\text { enfermagem } \\
12 \text { enfermeiros } \\
\text { Total: } 41 \\
\end{array}$ & $\begin{array}{c}24 \text { auxiliares de } \\
\text { enfermagem } \\
9 \text { enfermeiros } \\
\text { Total: } 33 \\
\end{array}$ & $\begin{array}{l}11 \text { auxiliares de } \\
\text { enfermagem } \\
3 \text { enfermeiros } \\
\text { Total: } 14 \\
\end{array}$ & $\begin{array}{c}12 \text { auxiliares de } \\
\text { enfermagem } \\
3 \text { enfermeiros } \\
\text { Total: } 15 \\
\end{array}$ \\
\hline
\end{tabular}

Fonte: tópicos estruturados pela mestranda Ana Silvia de Moraes e conteúdo estabelecido pela autora.

Outros materiais utilizados:

Nos encontros de formação distribuímos uma breve apostila (Apêndice A) explicativa, apresentando cada indicador com descrições e exemplos para auxiliar as aplicações do IRDI realizadas pelos profissionais de enfermagem. Esse material foi baseado numa apostila ${ }^{9}$ criada pelo Grupo Nacional da Pesquisa Multicêntrica para os pediatras formados por ela. A linguagem e o contexto de trabalho apresentados na breve apostila adaptada foram alterados com a finalidade de aproximá-la da realidade dos profissionais da atenção básica à saúde em formação.

Os vídeos com cenas ilustrativas de cada indicador do protocolo, utilizados nos encontros de formação, foram realizados e concedidos pelos pesquisadores da pesquisa multicêntrica.

As fichas de acompanhamento, estratégia para coleta de dados, foram criadas pela autora deste trabalho e por Ana Silvia de Morais, também mestranda do Programa Psicologia Escolar e Desenvolvimento Humano, as quais têm estruturado a formação juntamente com o orientador Rogério Lerner e participantes de seu grupo de pesquisa.

\footnotetext{
${ }^{8}$ A equipe organizadora teve o auxilio das demais orientandas participantes do grupo de pesquisa: Angela Flexa Di Paolo, Edna Márcia Bronzatto e Nathalia Campana.

${ }^{9}$ Kupfer et al. (2003). Apostila para Capacitação de Pediatras da Pesquisa Multicêntrica de Indicadores Clínicos de Risco para o Desenvolvimento Infantil. Produção técnica não publicada.
} 


\subsection{Contextualizando o local do estudo e algumas práticas dos participantes}

O estudo aconteceu em 14 Unidades Básicas de Saúde (UBS) do município de Embu das Artes, sendo que sete delas contam com o programa Estratégia Saúde da Família (ESF). Considerando os princípios que norteiam a Resolução 196/96, obtivemos a aprovação do Comitê de Ética em Pesquisa - IPUSP e autorizações dos centros de saúde para a realização dessa pesquisa, assim como assinaturas do Termo de Consentimento Livre e Esclarecido (Apêndice B), por todos os participantes.

A entrada no campo de pesquisa foi realizada através de uma parceria com a pediatra Dra . Rosa Resegue do Departamento de Pediatria Comunitária da Universidade Federal de São Paulo, a qual permitiu que a pesquisa ocorresse no Embu e concedeu assistência no Projeto Desenvolver as crianças identificadas em risco pelo IRDI.

$\mathrm{O}$ orientador dessa pesquisa teve reuniões com a $\mathrm{Dr}^{\mathrm{a}}$. Rosa e responsáveis pela Secretaria de Saúde da Criança, Saúde Mental e Educação em Saúde do município para apresentar o projeto de pesquisa e ajustá-lo com a finalidade de também atender as expectativas e necessidades do município.

Realizados os acordos com as secretarias, os profissionais foram convidados a participar da formação e se inscreveram voluntariamente de acordo com interesses pela temática - Formação de profissionais da atenção básica à saúde para utilização de Indicadores Clínicos de Risco de Desenvolvimento Infantil (IRDI), sendo o certificado emitido pelo Instituto de Psicologia da Universidade de São Paulo, como curso de difusão.

Alguns profissionais participaram dos encontros formativos durante o horário de trabalho e para os que não estavam, foi realizado um acordo com as chefias de cada unidade para que recebessem uma folga a cada encontro do curso.

As UBSs do município realizam atendimentos nas especialidades: clínico geral, pediatra, ginecologia/obstetra e dentista. Acolhem os pacientes através da equipe de enfermagem que, de forma geral, se divide e rodizia a cada 2 meses entre diversas atividades de prevenção, promoção da saúde e bem estar da comunidade, dentre elas: fazem cadastramento do bolsa família; acolhimento (quando o paciente chega a unidade sem consulta marcada é verificada a queixa e 
dado o encaminhamento); controle e administração de vacinas; grupos de gestantes, hipertensos, e diabéticos; atendimento de enfermagem em pediatria - AE (assistência ao bebê de 0 a 15 meses de vida realizada pela equipe de enfermagem); visitas domiciliares. Além de realizarem procedimentos como verificação de pressão arterial, curativo, inalação, exame eletrocardiovascular e ginecológico (coleta de papanicolau), coleta de sangue e teste de gravidez.

As políticas públicas de saúde da criança do município de Embu propõem que os bebês sejam avaliados e acompanhados desde muito cedo. Os bebês residentes no município são cadastrados ainda na maternidade no programa de Vigilância do Crescimento e Desenvolvimento com Enfoque de Risco, sendo avaliados nos primeiros 15 dias de vida por enfermeiros das UBSs, onde são identificados os bebês em risco (peso ao nascer menor que $2.500 \mathrm{~g}$; idade materna menor que 18 anos; morte de irmão com menos de 5 anos; intercorrências neonatais; outras situações não previstas, mas consideradas de risco), os quais terão maior frequência nos acompanhamentos médicos e de enfermagem. Já os bebês de baixo risco apresentam a seguinte frequência nos atendimentos de enfermagem: 2, 4, 8, 10 e 15 meses e nas consultas médicas: 1, 2, 3, 6, 9, 12 e 18 meses.

Como procedimento, portanto, enfermeiros e auxiliares de enfermagem atuam diretamente nesse seguimento. Os enfermeiros realizam uma primeira consulta que costuma ocorrer nos primeiros 15 dias de vida do bebê, na qual além de ser realizado exame físico, orientação quanto a amamentação e demais dúvidas dos pais, se estabelece um vínculo entre a família, o bebê e a unidade de saúde que os acompanharam. Esse primeiro contato é promissor para que as famílias retornem nos demais AEs realizados pelos auxiliares. Em alguns serviços os AEs são realizados em grupo, onde orientações são dadas aos pais de acordo com as necessidades da faixa etária da criança (amamentação, higienização, estimulação neuro motora, hábitos alimentares, risco de acidentes, entre outras), o ganho ponderal do bebê também é verificado e as vacinas são atualizadas, caso necessário.

Drª ${ }^{a}$ Rita de Cássia Kisukuri, em relatório da Atenção Básica da Saúde da Criança, de 2009, concedido pela Secretaria de Saúde da Criança de Embu, apresenta o número de grupos e de atendimentos de enfermagem em pediatria realizados no ano a que se refere, pelas auxiliares de enfermagem. Foram realizados no total 2.238 grupos e 9.521 atendimentos a bebês de 0 a 15 meses. 
Nesse mesmo relatório estão descritos outros programas de atenção à saúde da criança, como: Projeto Desenvolver (assistência interdisciplinar a crianças com risco de atraso do desenvolvimento ou com atraso já instalado, formada por neurologista, pediatra, fonoaudióloga, fisioterapeuta, psicóloga em parceria com a Universidade Federal de São Paulo); atendimento às crianças com doenças agudas; atendimento às crianças portadoras de doenças crônicas; programa de atenção à criança asmática; programa de combate às principais carências nutricionais; programa de incentivo ao aleitamento materno; comitê de prevenção de mortalidade infantil; programa de vigilância alimentar e nutricional; programa bolsa família; programa de apoio materno infantil; programa de vigilância e maus tratos na infância e programa de educação continuada em pediatria - desde 2001 ocorrem mensalmente capacitações para pediatras, enfermeiros, auxiliares de enfermagem e agentes comunitários, referentes a diversos temas sobre a saúde da criança.

\subsection{Instrumentos e procedimentos para coleta de dados}

Como trabalhamos com entrelaçamento de 2 perguntas principais, tivemos duas diferentes estratégias para a coleta de dados:

1-Preenchimento pelos profissionais de 4 fichas de acompanhamento (Fichas 1, 2, 4 e 5, Apêndices D, E, F e G, respectivamente) e uma ficha de avaliação do curso (Apêndice C). Visando coletar dados que evidenciassem os efeitos dessas estratégias formativas, desenvolvemos, a cada encontro de formação, fichas de acompanhamento com a finalidade de analisarmos o conhecimento prévio desses profissionais quanto ao desenvolvimento infantil e fundamentos do IRDI, abordando suas atuações com bebês. Foi a partir desse material que fizemos análises estatísticas para comparar os dados sobre as concepções prévias dos profissionais com momentos posteriores à formação dada.

2-Monitorias: acompanhamento em serviço realizado pela pesquisadora com as seguintes finalidades: manter o vínculo com as profissionais em formação, realizar contato contínuo, esclarecer dúvidas sobre indicadores e aplicação do IRDI, acompanhar o andamento das 
aplicações, criar possíveis estratégias para soluções de impasses pessoais e institucionais, presenciar as aplicações realizadas pelos profissionais e discuti-las. Esses dados foram registrados após cada visita, gerando um diário de campo, o que deu um caráter qualitativo à pesquisa.

\subsubsection{Fichas de Acompanhamento}

Essa pesquisa foi sendo redesenhada ao longo do trabalho. Inicialmente, pensamos em realizar perguntas abertas e fechadas antes e depois de cada encontro formativo. No entanto, a proposta de formação era contínua e não se apoiava apenas em momentos estanques, fazendo parte da mesma monitorias em serviço após os encontros formativos. Assim, realizamos perguntas anteriormente aos encontros formativos e as refizemos após 3 meses de encerramento das monitorias.

As perguntas realizadas foram apresentadas por escrito aos participantes e chamadas de fichas de acompanhamento 1, 2, 4 e 5, aplicadas respectivamente em janeiro, março, dezembro de 2011 e setembro de 2012. Em agosto de 2011, realizamos um ficha avaliativa do curso (a ficha 3, Apêndice C), que serviu para entendermos as desistências dos participantes.

As fichas de acompanhamentos 1 e 2 (Apêndices D e F, respectivamente) aplicadas respectivamente antes do primeiro e do segundo encontros de formação continham perguntas abertas e fechadas. As fichas 4 e 5 contiveram apenas questões abertas, devido à melhor adequação ao que se buscava saber. No capítulo de resultados, apresentamos as análises das perguntas fechadas contidas nas fichas 1 e 2 , e posteriormente as perguntas abertas realizadas nas fichas $1,2,4$ e 5 .

As perguntas fechadas das fichas 1 e 2 foram estruturadas a partir da escala de Likert criada em 1932 por Rensis Likert (Selltiz, Wrightsman, Cook \& Kidder, 1987). Essa escala, de caráter ordinal, varia entre $+2,+1,-1,-2$, correspondendo, respectivamente, a: concordo fortemente, concordo, discordo e discordo fortemente. Os profissionais de saúde deveriam indicar o grau de concordância ou discordância, selecionando apenas uma opção para cada item. 
As respostas foram computadas e apresentadas em tabelas contendo as frequências em números e percentuais. No capítulo de resultados e discussão, apresentamos primeiramente esses dados, que na verdade servem de justificativa para evidenciar a necessidade de mudanças metodológicas, uma vez que os resultados não se apresentaram favoráveis para análises significativas.

Como demonstraremos nos resultados, as perguntas abertas evidenciavam mais claramente a realidade prática dos participantes e se mostraram mais interessantes para evidenciar os efeitos da formação, foi por esse motivo que as análises desse trabalho foram enfatizadas nas questões abertas sobre a prática dos participantes. Ao término do quarto encontro de formação a pergunta: “em sua prática com bebês, a que você procura ficar atento?”, considerando a variabilidade da faixa etária da criança (até 4 meses, até 8 , até 12 e até 18), havia sido realizada entre os encontros formativos: anteriormente ao primeiro, segundo e quarto. Porém, havia uma variação nessa pergunta: a idade do bebê. Então, por essa razão não poderíamos ter clareza se a variação na resposta era devido à formação ou à idade do bebê avaliado. Assim, seria difícil realizar uma análise comparativa entre essas perguntas e também não tínhamos nenhum material que permitisse comparar esses dados iniciais com dados finais, após finalização da intervenção realizada com os participantes. Justamente por não ser possível precisar o que era efeito dos encontros anteriores e o que condizia com a prática a priori dos participantes, e nem comparar as perguntas realizadas devido à variação da faixa etária, redesenhamos a pesquisa, passando a trabalhar com respostas das perguntas realizadas aos profissionais formados, nomeado de grupo intervenção e de outro grupo de profissionais que não participou da educação permanente e não teve nenhum contato com o IRDI, chamado de grupo controle.

Dessa maneira, seria possível comparar as respostas obtidas pelo grupo intervenção e grupo controle, bem como avaliar a apreensão do conhecimento e a aprendizagem. Após três meses do encerramento das monitorias em serviço, realizamos nova coleta de dados com o total de participantes nos 4 encontros formativos (12 profissionais) e outros 12 profissionais de saúde, que não passaram pela educação permanente e pertenciam as mesmas unidades básicas do grupo intervenção, caracterizando o grupo controle. As perguntas realizadas foram as mesmas para os dois grupos:

P1-Em sua prática com bebês de até 4 meses, a que você procura estar atento? 
P2- Em sua prática com bebês de até 8 meses, a que você procura estar atento?

P3- Em sua prática com bebês de até 12 meses, a que você procura estar atento?

P4- Em sua prática com bebês de até 18 meses, a que você procura estar atento?

A escolha dos profissionais para configurar o grupo controle foi aleatória, convidamos outros profissionais pertencentes às mesmas UBSs dos participantes da formação a responder algumas perguntas sobre atividades assistenciais de rotina desempenhadas com bebês. Tentamos manter como critério que o participante do grupo controle tivesse o mesmo cargo do profissional do grupo intervenção, o que teoricamente acarretava a eles funções parecidas dentro da instituição.

Os objetivos desse trabalho foram respondidos a partir de evidências em 3 âmbitos:

1. Diferença quantitativa entre profissionais do grupo intervenção e do grupo controle. 2. Transformações quantitativas e qualitativas intragrupo intervenção ao longo do tempo, nos momentos antes, durante e após a formação. 3. Apresentação e discussão de alguns sentidos, tanto favorecedores quanto defensivos, que a formação teve para os que passaram por ela (coletados em monitorias).

Considerando os objetivos propostos, realizamos as análises em diferentes níveis. Primeiramente, realizamos um estudo estatístico das questões abertas, que gerou frequências e percentagem para comparar as respostas obtidas no grupo controle e no grupo intervenção. As respostas foram indexadas, a princípio, em 2 categorias: 1- aspectos físicos: avaliação geral do bebê e avaliação do desenvolvimento e 2- aspectos psicológicos, envolvendo características relacionais do bebê com sua família.

A categoria 1 envolve todos os procedimentos de puericultura, como monitoramento do crescimento e medidas antropométricas; aleitamento materno exclusivo, alimentação e dados nutricionais; estado vacinal; histórico e precedentes maternos-infantis; ambiente familiar e condições sociais, e violência doméstica e maus tratos.

Nessa categoria também foram considerados tópicos estabelecidos pela Universidade Federal de São Paulo, que se propõem avaliar o desenvolvimento infantil do ponto de vista da criança, sem considerar muito sua relação com os demais. Trata-se de citações avaliativas do desenvolvimento 
sem especificações, desenvolvimento dos sentidos (fala, visão e audição), reações do bebê à estímulos e desenvolvimento neuropsicomotor. Embora alguns deles se aproximassem em alguma medida do IRDI (chora frente ao desconforto, sorri, acompanha com o olhar, olha nos olhos), os consideramos aspectos da categoria 1.

A categoria 1 considera a prática já instituída realizada nos atendimentos de assistência ao bebê desempenhados pelas profissionais de enfermagem do Embu. Como podemos observar em ficha de atendimento de enfermagem (Anexo B), esse protocolo de assistência é parâmetro para o acompanhamento de bebês, realizado pelas profissionais de enfermagem. Esse protocolo foi introduzido na rotina de todas as unidades do município, há mais de 20 anos, por uma universidade de medicina de São Paulo, e é fortemente orientada por modelos médicos avaliativos, como neurológicos, motores e biológicos.

Como buscamos verificar se a formação IRDI proposta aumentaria aos participantes a percepção de aspectos relacionais dos bebês com suas famílias, enfatizamos a análise nesses aspectos, criando a categoria 2. Nessa categoria, a princípio, reunimos menções à interação mãe-bebê de maneira inespecífica e de forma refinada, aspectos relacionais do desenvolvimento emocional, sentimentos das crianças e dos pais, bem como dados relacionados diretamente com os indicadores do IRDI e seus fundamentos. Essa categoria foi desmembrada quando analisamos as respostas apenas do grupo intervenção, comparando-as entre diferentes períodos de realização de perguntas: antes, durante e após a formação.

Nesse primeiro momento, analisamos as respostas de cada participante e verificamos quais categorias foram relatadas, se as mencionaram ou não, atribuímos valores 1 para sim e 0 para não para realização de cálculos, números e percentagens que se encontram em tabelas apresentadas no capítulo Resultados e Discussão.

Com esses dados, realizamos também um estudo de confiabilidade, chamado análise de concordância - Kappa (Laboratório de Epidemiologia e Estatística - Lee, 1995), com a finalidade de obtermos credibilidade na análise realizada. Um aluno de graduação do Instituto de Psicologia da Universidade de São Paulo também categorizou todas as respostas obtidas pelas perguntas realizadas para o grupo intervenção e o grupo controle. 
O estudo de confiabilidade se deu às cegas e utilizou-se o mesmo processo descrito acima, sendo as repostas separadas em 2 categorias: aspectos físicos e psicológicos do desenvolvimento do bebê. Na tabela abaixo apresentamos as interpretações da análise de concordância de cada valor considerado pelo teste Kappa:

Tabela 3 - Interpretação do grau de concordância obtida pela estatística de Kappa.

\begin{tabular}{cc}
\hline Valores do kappa & Interpretação \\
\hline$<0.00$ & Pobre \\
$0.00-0.20$ & Fraca \\
$0.21-0.40$ & Razoável \\
$0.41-0.60$ & Moderada \\
$0.61-0.80$ & Substancial \\
$0.81-1.00$ & Excelente
\end{tabular}

Fonte: Landis e Koch (1977)

Em seguida, analisamos a frequência quanto à menção aos aspectos psicológicos, ou seja, contamos quantas vezes o aspecto psicológico foi referido e novamente estabelecemos comparações entre os grupos pós-intervenção e controle. Com esses dados, também foi realizada uma análise por comparação entre grupos, um teste não paramétrico para amostras independentes, chamado Mann-Whitney que testa se existe uma diferença estatística significativa entre as médias de duas amostras independentes. (Reidy \& Dancey, 2006) O nível de significância adotado foi 0,05 .

Adiante, trabalhamos com os dados obtidos antes, durante e 3 meses após o encerramento da formação do grupo intervenção, ou seja, comparamos os dados do intragrupo. Fazem parte do grupo intervenção 12 profissionais que realizaram os 4 encontros da formação IRDI. Comparamos as respostas referentes às perguntas: em sua prática com bebês de até 4,8 e 18 meses, a que você procura estar atenta?, realizada em 3 diferentes momentos: janeiro, março e dezembro de 2011 com as mesmas perguntas refeitas em setembro 2012, e incluímos ainda uma faixa etária, de até 12 meses do bebê.

No capítulo Resultados e Discussão, diferenciamos os momentos em que as respostas foram obtidas nesse grupo. Para nos referirmos às análises de perguntas realizadas após o término da 
formação, nomeamos grupo pós-intervenção e grupo pré e durante intervenção para as perguntas realizadas antes e durante a formação, conforme é possível visualizar no Cronograma da Formação IRDI e da Coleta de Dados (página 45).

Realizamos os mesmos procedimentos de análises com os dados obtidos no intragrupo, ou seja, em 3 momentos, anterior, durante e após a intervenção. Analisamos as respostas de cada participante nesses diferentes momentos de coleta de dados e verificamos se categorias físicas e psicológicas foram mencionadas ou não. As frequências com que as respostas psicológicas apareceram também foram computadas para cada faixa etária questionada e comparadas entre diferentes momentos, os dados foram apresentados em números absolutos. Com esses dados, também realizamos o teste Wilcoxon, não paramétrico para amostras pareadas. Apresenta o mesmo fundamento de comparação de grupos do teste de Mann-Whitney, no entanto, é aplicado quando os participantes do estudo são os mesmos. (Reidy. \& Dancey, 2006) O nível de significância utilizado foi 0,05 .

Aprofundamos as análises nos relatos do intragrupo quanto aos aspectos psicológicos, para isso as respostas foram categorizadas em 2 aspectos: amplos e específicos. Aspectos amplos incluem citações sem muitas especificações como a interação do bebê com sua família e vice-versa; já os específicos, consideram indicadores e fundamentos do IRDI, bem como sentimentos dos bebês. Calculamos o número de profissionais que citaram tais aspectos e também se citavam ambos. Verificamos também a frequência dessas respostas quanto a essas mesmas categorias e as comparamos nos diferentes momentos que a pergunta foi realizada no intragrupo (pré, durante e após formação).

Na sequência, realizamos uma descrição qualitativa considerando cada sub-categoria (indicadores e fundamentos do IRDI, e sentimentos dos bebês) dos aspectos específicos. Essa análise teve o objetivo de evidenciar e especificar como ocorreu o processo de aprendizagem dos aspectos psicológicos no intragrupo, mais do que comparar as respostas obtidas entre os momentos antes, durante e após formação. Dados de monitorias em serviço também foram incluídos nessa análise, com a intenção de considerar na discussão os sentidos do uso do IRDI e sua apreensão. 


\subsubsection{Acompanhamentos em serviço}

Entre os encontros de formação, foram realizadas visitas quinzenais às unidades básicas. Em cada centro, a monitoria ocorreu de uma maneira diferente, conforme a demanda de cada participante e a realidade de cada serviço. Foi uma proposta de interação entre a pesquisadora e os participantes, tornando a formação contínua e que contemplasse o conhecimento prévio dos profissionais - suas teorias e ideias diante da prática com bebês. O acompanhamento em serviço também foi constituído de discussões de anseios e dificuldades dos profissionais de enfermagem diante dessa prática, até mesmo os suscitados pelo próprio uso do IRDI. Consideramos assim, as particularidades de cada profissional a partir dessa experiência e realizamos a partir de então, uma discussão qualitativa articulando a teoria psicanalítica de Melanie Klein e dados científicos da área de enfermagem e saúde.

Entendemos que dessa maneira estaríamos diante de uma importante instrumentalização de leitura qualitativa do contexto envolvido na realidade das participantes, conforme refere Minayo (2010, p. 31):

todas as ações clínicas, técnicas, de tratamento, de prevenção ou de planejamento devem estar atentas aos valores, atitudes e crenças das pessoas a quem a ação se dirige. É preciso entender que, ao ampliar suas bases conceituais incluindo o social e o subjetivo como elementos constitutivos, as ciências da saúde não se tornam menos "científicas", pelo contrário, elas se aproximam com maior luminosidade dos contornos reais dos fenômenos que abarcam.

A partir dessa argumentação, interagimos com os participantes considerando o que eles pensavam sobre os assuntos abordados, construindo o conhecimento a partir da experiência que eles estabeleciam conosco e com o próprio IRDI, instrumento utilizado para avaliar o desenvolvimento emocional infantil. Essa posição norteou toda a formação, mas, como as monitorias estabeleciam uma relação próxima entre a pesquisadora e os profissionais, foi ainda mais nesse contexto que esse estreitamento se deu. Os acompanhamentos em serviço nos permitiram o acesso à cultura dos serviços de saúde e ao sentido atribuído ao IRDI pelas participantes dessa intervenção em educação permanente.

Considerando a cultura como uma teia semiótica, ou seja, uma rede significados e um fluxo de acontecimentos sociais (Geertz, 1989), nos deparamos com um campo de sentidos que é 
construído pelo outro e, no caso de pesquisas qualitativas, pelo pesquisado, como o significado de um comportamento. Para o autor, a análise da cultura só ocorre em relação e é a partir da interação entre pesquisador-pesquisado que a interpretação da cultura pode ser realizada.

Durante as monitorias, tivemos acesso à cultura dos serviços de saúde e das práticas instituídas. No entanto, focamos nos sentidos que o uso do IRDI tiveram para as profissionais. Percebemos que nos dispositivos de saúde também se constrói conhecimento técnico advindo da própria prática e por isso, consideramos o conhecimento dos profissionais e, a partir dele, novos foram produzidos, permitindo que tanto o pesquisador como pesquisado participassem em conjunto do processo de formação.

Em algumas unidades acompanhávamos os AEs e as aplicações do IRDI realizados pelas participantes da formação, seguidas de discussão, muitas vezes em grupos. Em outros serviços, não por falta de oferta em participarmos dos atendimentos, mas por vontade dos profissionais, apenas conversávamos sobre as aplicações e dificuldades encontradas. Percepções sobre o desenvolvimento emocional do bebê sempre apareciam e eram valorizadas.

Articulamos características da formação com conceitos de grupos operativos descritos por Pichon-Rivière (1988). O autor relata que em uma situação grupal está em jogo a interação de dois aspectos: o intersubjetivo (grupo externo) e o intrassubjetivo (grupo interno) e diante dessa configuração os modelos internos se confrontam e se modificam na situação grupal, construindo um novo esquema referencial que emerge da produção do grupo.

Pichon-Rivière (1988), ao propor a técnica operativa do grupo, define-o como uma estrutura básica de interação e considera que toda situação de aprendizagem se estende a todo processo de interação, ou seja, a aprendizagem decorre de interações. Para o autor o processo de aprendizagem acontece "como um processo unitário, como experiência contínua e dialética, na qual o papel do docente e o papel do aluno são funcionais e complementares.” (1988, p. 177)

Dessa maneira, a noção de aprendizagem para o autor "está sustentada em uma dialética que a caracteriza como a apropriação instrumental da realidade, para modificá-la. A noção de aprendizagem se vincula intimamente com o critério de adaptação ativa à realidade ...” (1988, p. 176) Relações estabelecidas no trabalho entre profissional e paciente e as estabelecidas no 
processo de formação entre formandos e formadores se mostraram com grande potencial para construção de conhecimento.

No sub-item Uma perspectiva qualitativa de apropriação do IRDI, do capítulo Resultados e Discussão, apresentamos cenas seguidas de discussão norteada por basicamente 3 questões que surgiram do próprio campo: elementos que proporcionam o engajamento na formação e o uso do IRDI, bem como o abandono de ambos e posições internas e externas que possibilitam superar dificuldades encontradas para tanto.

Realizamos uma discussão interpretativa, portanto qualitativa, dos dados à luz da teoria psicanalítica de Melanie Klein, assim como articulamos dados de produções científicas da área de enfermagem e saúde. Os dados de monitoria também foram articulados aos resultados quantitativos apresentados em itens anteriores.

\subsection{Caracterização dos participantes dos grupos controle e intervenção}

Dada a prevalência do sexo feminino na área da saúde e na assistência (Godinho, Ristoff, Fontes, Xavier, Sampaio, 2006) ${ }^{10}$, os 12 participantes do grupo intervenção (100\%) são do sexo feminino e a maioria dos profissionais que formaram o grupo controle $(91,7 \%$ ) é do sexo feminino, enquanto $8,3 \%$ são do sexo masculino, como demonstrado no gráfico abaixo:

\footnotetext{
${ }^{10}$ Os autores realizaram um estudo com dados do INEP (1996-2003) e apontaram que 84,7\% das matrículas em cursos de Enfermagem são do sexo feminino, colocando-o em $9^{\circ}$ lugar entre os 10 cursos com maiores percentuais de mulheres.
} 
Gráfico 1 - Gênero dos participantes dos grupos intervenção e controle.

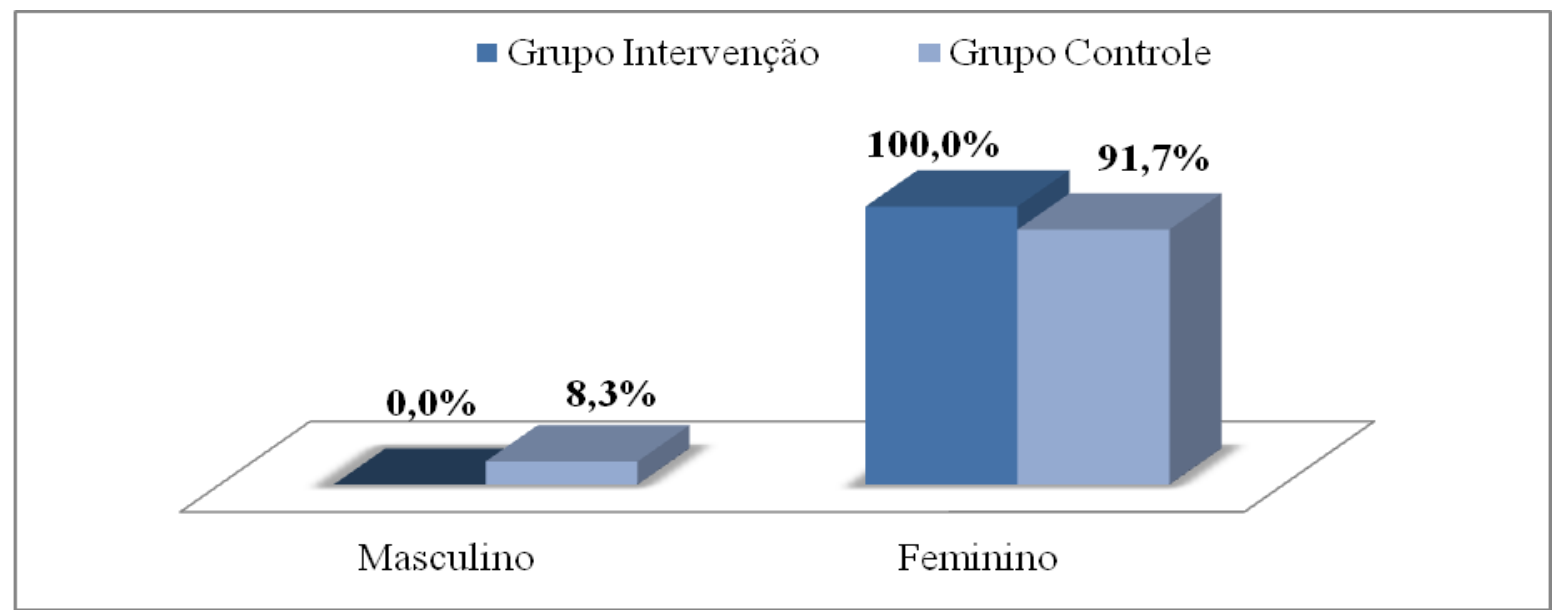

De acordo com o gráfico 2, a faixa etária desses profissionais varia um pouco, predominando, entre os profissionais do grupo intervenção, a faixa de 40 a 49 anos, com 50,0\%, seguida das faixas de 30 a 39 e 50 ou mais, com 25,0\% cada. A faixa predominante entre os participantes do grupo controle é a de 30 a 39 anos (41,7\%), em segundo lugar ficou a de 40 a 49 anos, com $33,3 \%$ e em terceiro a de 50 anos ou mais, $25,0 \%$.

Gráfico 2 - Faixa etária dos participantes dos grupos intervenção e controle.

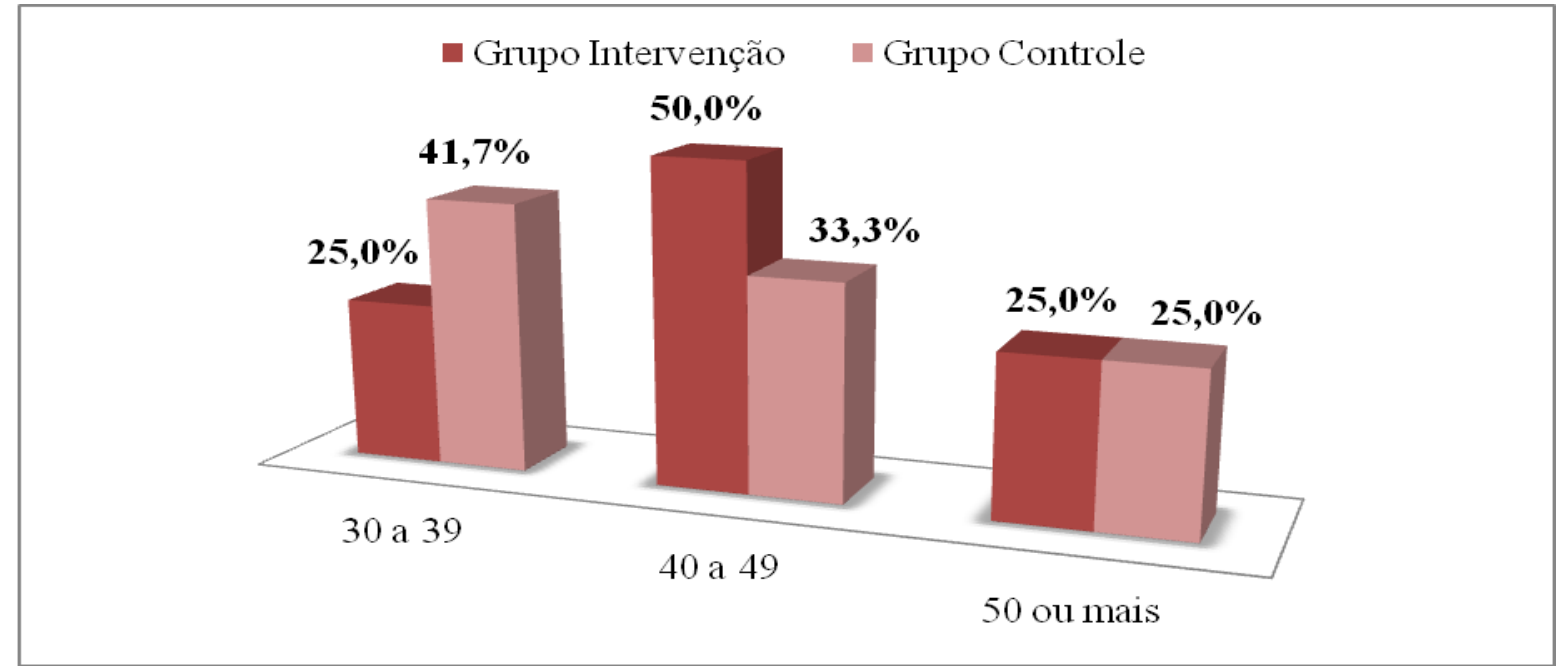

Com relação à formação prévia, os dados não divergem muito entre os grupos intervenção e controle: $75 \%$ dos participantes do grupo intervenção têm ensino médio completo e $25 \%$ têm superior completo; entre os profissionais do grupo controle 83,3\% têm ensino médio completo e $16,7 \%$ superior completo, como apresentado no gráfico 3 : 
Gráfico 3 - Grau de instrução dos participantes dos grupos intervenção e controle.

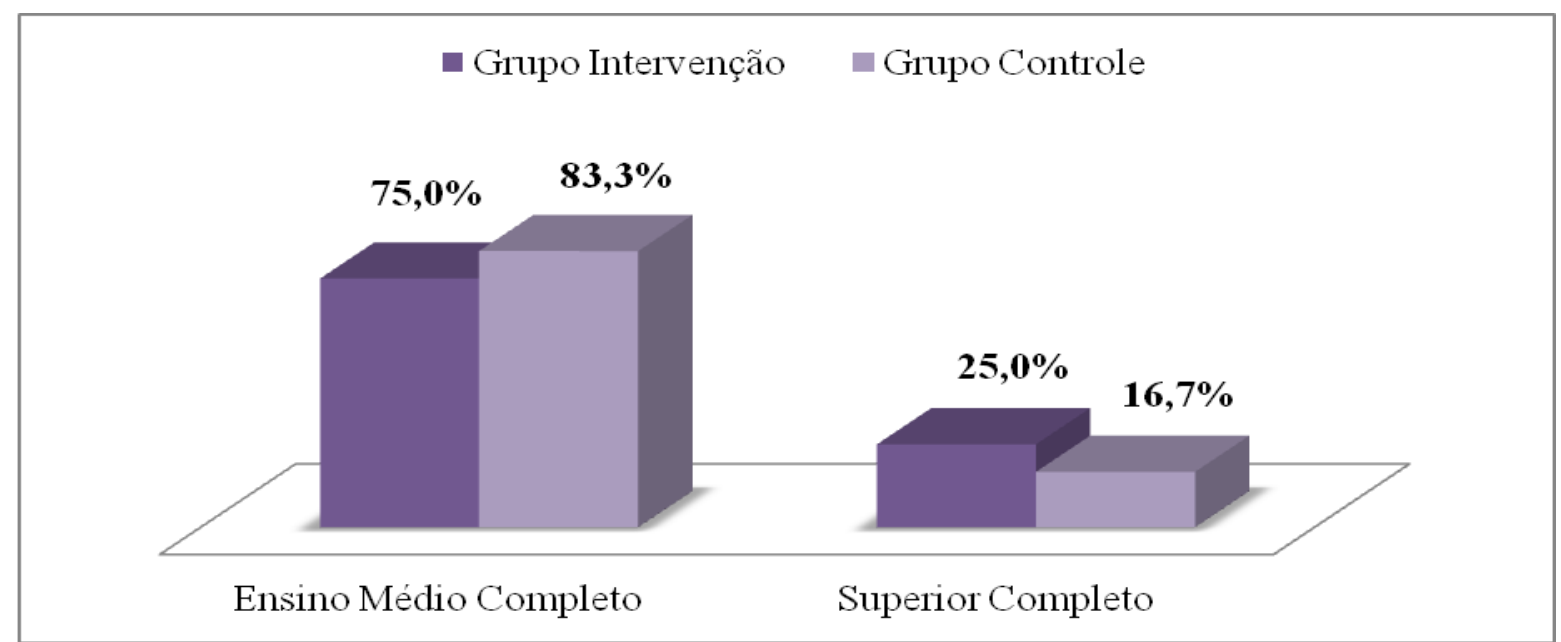

Outro importante dado levantado foi o tempo que os profissionais trabalham com bebês, no grupo intervenção, temos a maior percentagem (33,3\%) trabalhando de 9 a 15 anos, $25 \%$ de 4 a 8 anos; $16,7 \%$ de 1a 3 anos; $16,7 \%$ de 16 a 25 anos e 8,3\% há mais de 25 anos. No grupo controle prevalecem $33,3 \%$ de 4 a 8 anos; $25 \%$ há mais de 25 anos; $16,7 \%$ de 16 a 25 e 8,3\% de 9 a 15 anos; 8,3\% há menos de um ano e de 1 a 3 anos, como representado no gráfico 4:

Gráfico 4-Tempo de trabalho com bebês dos participantes dos grupos intervenção e controle.

\begin{tabular}{|c|c|c|c|}
\hline \multirow{2}{*}{$\begin{array}{c}\text { Menos de } \\
1 \text { ano }\end{array}$} & $0,0 \%$ & \multirow[t]{2}{*}{ Grupo Intervenção } & \multirow[t]{3}{*}{ Grupo Controle } \\
\hline & $8,3 \%$ & & \\
\hline $\begin{array}{c}\text { De } 1 \text { a } 3 \\
\text { anos }\end{array}$ & $16,7 \%$ & $8,3 \%$ & \\
\hline $\begin{array}{c}\text { De } 4 \text { a } 8 \\
\text { anos }\end{array}$ & \multicolumn{2}{|c|}{$25,0 \%$} & $33,3 \%$ \\
\hline $\begin{array}{c}\text { De } 9 \text { a } 15 \\
\text { anos }\end{array}$ & \multicolumn{2}{|r|}{$33,3 \%$} & $8,3 \%$ \\
\hline $\begin{array}{l}\text { De } 16 \text { a } \\
25 \text { anos }\end{array}$ & $16,7 \%$ & $16,7 \%$ & \\
\hline $\begin{array}{l}\text { Mais de } \\
25 \text { anos }\end{array}$ & $8,3 \%$ & $25,0 \%$ & \\
\hline
\end{tabular}




\section{Resultados e Discussão}




\subsection{Número de participantes ao longo do estudo}

Como os encontros formativos ocorreram ao longo do ano de 2011, contabilizamos o número de participantes presentes em cada um, conforme apresentado no gráfico 5.

Gráfico 5 - Número de enfermeiros, auxiliares de enfermagem e total de profissionais participantes em cada encontro formativo.

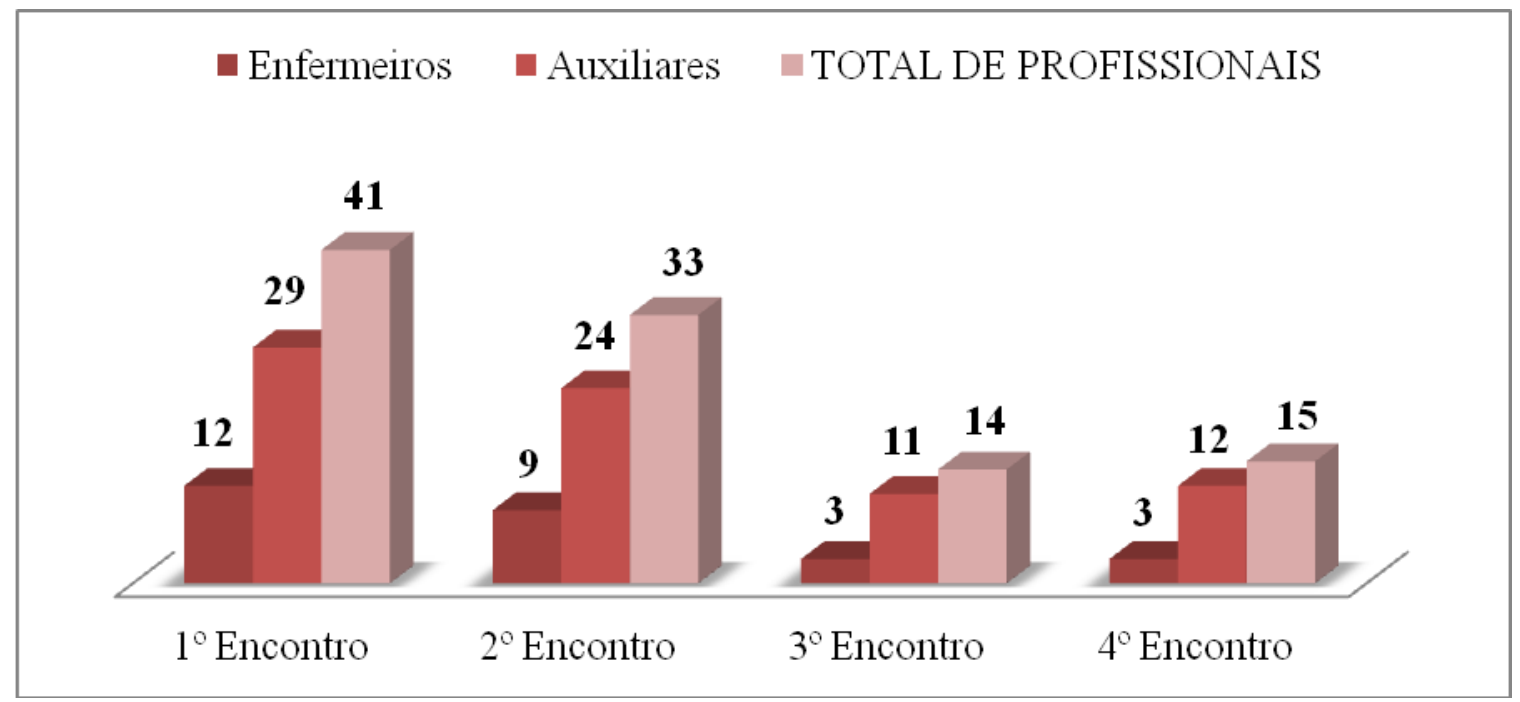

Inicialmente, a população do estudo somava 41 profissionais, 12 enfermeiros $(29,2 \%)$ e 29 auxiliares de enfermagem (70,7\%). No segundo encontro, tivemos a presença de 9 enfermeiros (27,2\%), 24 auxiliares (72,7\%), totalizando 33 participantes. No terceiro e quarto encontro há uma grande diminuição no número de participantes, $3(21,4 \%)$ enfermeiros e $11(78,5 \%)$ auxiliares, somando 14, seguidos de $3(20,0 \%), 12(80,0 \%)$ totalizando 15 respectivamente.

Verificamos também quantos participantes se mantiveram nos 4 encontros, os que estiveram apenas no primeiro, no primeiro e segundo e em 3 deles, os números de profissionais presentes nos diferentes encontros formativos foram evidenciados no gráfico 6. 
Gráfico 6 - Número de profissionais presentes nos encontros.

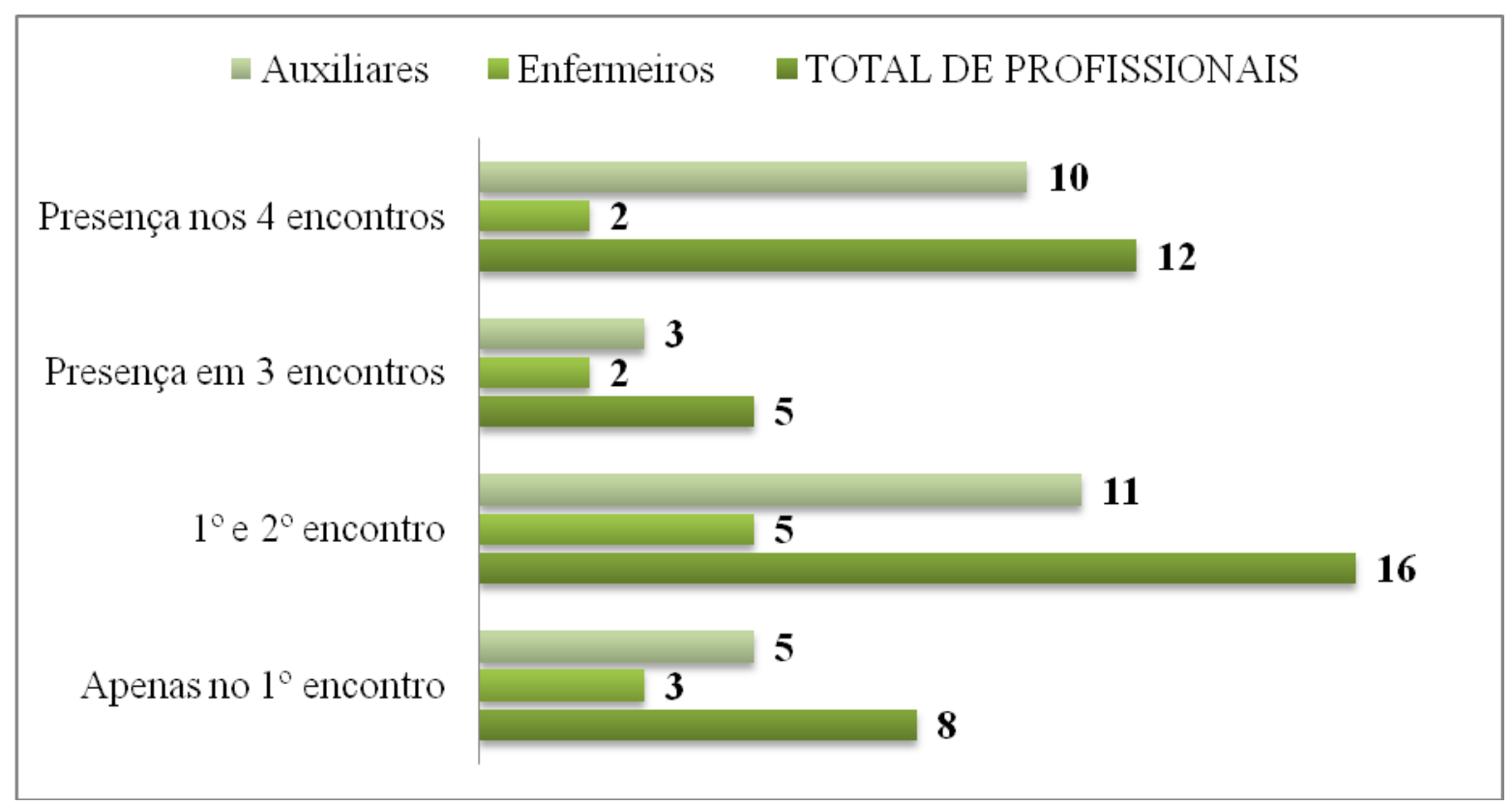

Conforme gráfico acima, estiveram presentes em todos os encontros formativos um total de 12 participantes, sendo 2 enfermeiros e 10 auxiliares. Em 3 deles, somaram 5 profissionais (2 enfermeiros e 3 auxiliares). Apenas no primeiro e segundo encontro estiveram presentes 16 participantes ( 5 enf. e 11 aux.) e 8 ( 3 enf. e 5 aux.) estiveram somente no primeiro encontro formativo.

Notamos número reduzido de profissionais que participaram dos 4 encontros (12), quando comparados com os 41 iniciais, por isso verificamos também como o declínio de participantes se deu ao longo do estudo, evidenciando as perdas ocorridas entre um encontro e outro. Esse dado foi ilustrado no fluxograma Número de Participantes por Encontro Formativo e Respectivas Perdas em Percentagens, apresentado na página seguinte. 
NÚMERO DE PARTICIPANTES POR ENCONTRO FORMATIVO E RESPECTIVAS PERDAS EM

\section{PERCENTAGEM}

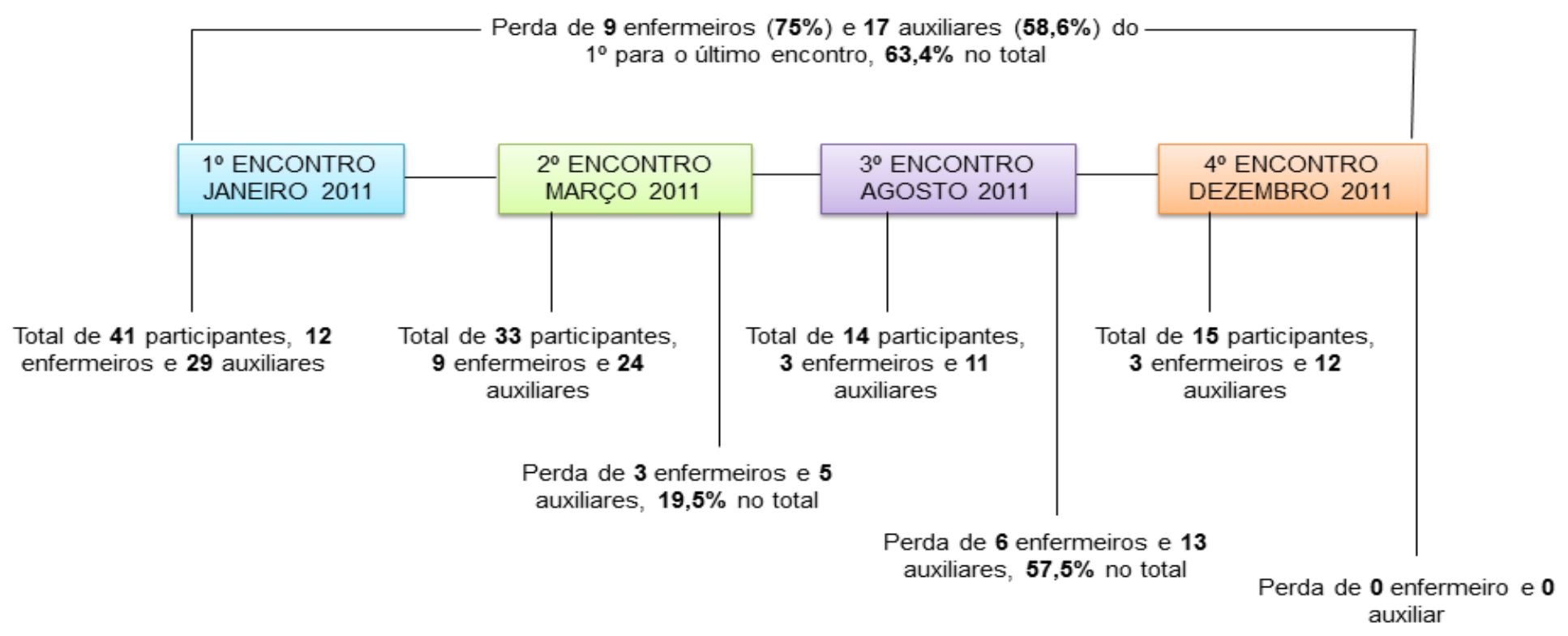

Mostramos que $80,5 \%$ dos participantes iniciais estavam presentes no segundo encontro (perda de $19,5 \%$ ), 42,5\% no terceiro (perda de 57,5\%) e 36,6\% no quarto. Do primeiro encontro formativo para o último tivemos uma perda de 63,4\% dos participantes. Perdas eram esperadas, por se tratar de um estudo a longo prazo, no entanto, nos questionamos os motivos e, a princípio, alguns dados iniciais colhidos nas monitorias puderam nos fazer entendê-los.

Em monitoria, algumas participantes relataram os motivos para as desistências, como falta de interesse no assunto e na assistência ao bebê, principalmente a não realização dos AEs (atendimento de pediatria em enfermagem) pela profissional. Embora seja estabelecido um rodízio entre as funções das auxiliares dentro das unidades básicas, nem sempre isso ocorre, ficando a critério das profissionais e da chefia a definição da área de atuação, podendo ser considerada a afinidade da funcionária. Sem contar as profissionais que se ausentaram devido transferências, demissões, aposentadorias, mudanças de turno, novos compromissos e cursos, e 
até mesmo o não cumprimento das chefias em fornecer uma folga em troca da participação no encontro de formação.

Com a finalidade de aprofundar o entendimento das desistências, realizamos uma ficha de avaliação do curso (Apêndice C), que foi entregue a todos os participantes após o segundo encontro de formação. Esses dados foram apresentados e discutidos no item seguinte.

\subsection{Entendendo as "desistências"}

Após o segundo encontro formativo, ouvimos dos participantes, durante as monitorias, dificuldades em dar continuidade ao curso e em aplicar o protocolo. Diante disso, decidimos realizar uma ficha de avaliação do curso, entregue 15 dias antes do terceiro encontro e recolhida no dia do encontro. Essa ficha teve como propósito investigar qual havia sido a frequência desses profissionais nos encontros de formação e a frequência do uso do IRDI na rotina de trabalho deles.

A partir das falas dos profissionais em monitoria, realizamos hipóteses quanto aos empecilhos em participar da formação e o grau de dificuldade com o protocolo, que deveriam ser respondidos por todos que iniciaram a formação. A ficha avaliativa foi respondida por 17 profissionais, sendo que desses, 2 não estavam mais participando da formação (estiveram presentes apenas no primeiro encontro) e nem estavam utilizando o IRDI, justificando sua evasão com a falta de tempo, devido a demais atividades na UBS e outros cursos oferecidos pelo município. Portanto, 15 profissionais de enfermagem (4 enfermeiros e 11 auxiliares) estiveram presentes até o terceiro encontro e todos estavam utilizando o IRDI em seus atendimentos ao bebê.

O número de desistentes ao longo do curso é maior do que 17, mas nem todas as pessoas que desistiram responderam a essa ficha, o que não nos permite obter grande conclusão sobre os motivos das desistências, por essa via.

Na tabela abaixo, segue síntese dos resultados sobre principais motivos para uso do protocolo, questionados na ficha avaliativa. 
Tabela 4 - Motivos para uso do IRDI pelos profissionais de enfermagem em número e percentagem.

\begin{tabular}{lcc}
\hline Motivos para uso do IRDI & N & \% \\
\hline Posso contribuir com a detecção de problemas graves na infância & 12 & 100 \\
Quero aprender mais sobre assunto & 8 & 66,7 \\
Faz parte da minha função & 5 & 41,7 \\
A aplicação tem ajudado no meu trabalho & 1 & 8,3 \\
\hline
\end{tabular}

Dos 15 profissionais de enfermagem que continuaram a formação, $12(80 \%)$ responderam que estavam aplicando o IRDI e quanto às justificativas para isso, todos (12, 100\%) mencionaram que acreditam que podem contribuir com a detecção de problemas graves na infância, $8(66,7 \%)$ profissionais afirmam que estão motivados por aprender mais sobre o assunto, $5(11,4 \%)$ acham que aplicar o IRDI deve fazer parte da função que eles exercem e uma pessoa $(8,3 \%)$ disse que a aplicação tem ajudado seu trabalho.

Considerando que estávamos pouco antes do terceiro encontro, questionamos se os profissionais haviam tido alguma influência, pela formação, em suas práticas e verificamos que dos 15 participantes, uma pessoa respondeu que não e outra disse que havia passado a usar o IRDI como parâmetro em sua rotina avaliativa de bebês. Dos demais, 40\% relataram que houve uma melhora na observação da interação entre o bebê e sua família, 25\% mencionaram observar como a criança se dirige ao outro e como os pais se dirigem a ela, outros $25 \%$ falaram que a formação ajudou a atuação deles de forma geral, aprimorando a prática de maneira inespecífica e 10\% citaram o aprimoramento da avaliação do desenvolvimento bom ou em risco como um benefício da formação. De forma geral, esses dados revelam avanços conquistados com a formação quanto ao trabalho com bebês e observação de seus aspectos emocionais.

Nessa mesma ficha de avaliação, questionamos também o grau de dificuldade que encontraram quanto à aplicação do IRDI, seguem resultados: 
Gráfico 7 - Grau de dificuldade com protocolo IRDI e aplicações.

Nenhuma Dificuldade $\quad$ Pouca Dificuldade $\quad$ Média Dificuldade $\quad$ Muita Dificuldade

Conciliar a aplicação do protocolo e o trabalho na unidade Acompanhar as familias e os bebês durante 18 meses

Ter apoio de superiores e outros funcionários

Entendimento dos itens do protocolo

Falar da proposta com cuidadores

Entendimento das instruções dadas no curso

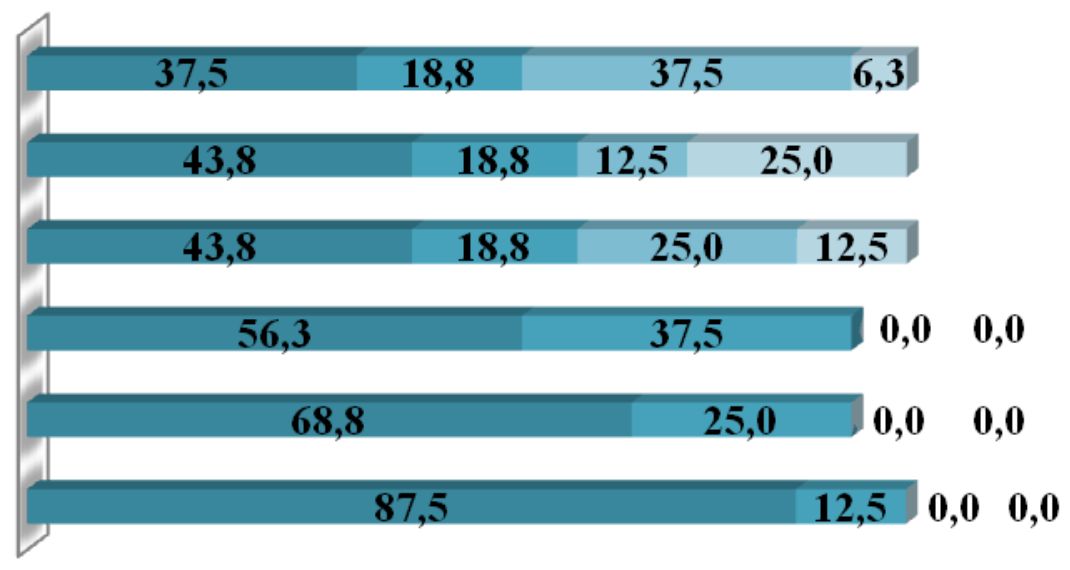

Os 6 aspectos avaliados, no gráfico acima, foram estruturados a partir dos dados colhidos em monitorias ocorridas após o primeiro e segundo encontro de formação e de forma geral mostram que os profissionais não tiveram dificuldades quanto a esses aspectos.

Os profissionais apresentaram média e muita dificuldade em 3 itens: conciliar o uso do IRDI com a rotina da unidade já estabelecida $(37,5 \%$ e 6,3\%, respectivamente), $12,5 \%$ e 25\% tiveram média e muita dificuldade com o fato do IRDI se propor a ser um seguimento que acompanha longitudinalmente os bebês e seus cuidadores e $25 \%$ e $12,5 \%$ respectivamente, em ter apoio dos colegas de trabalho.

Quanto aos itens "entendimento dos itens do protocolo", "falar da proposta com cuidadores", e "entendimento das instruções dadas no curso", os profissionais só apresentaram nenhuma ou pouca dificuldade, sendo que a maioria mencionou não ter nenhuma dificuldade $(56,3 \%, 68,8 \%$ e $87,5 \%$, respectivamente) quanto a esses aspectos e entre os que mencionaram pouca dificuldade temos $37,5 \%, 25 \%$ e $12,5 \%$, respectivamente.

Esses dados sugerem que os profissionais puderam compreender bem as instruções quanto ao IRDI e os itens do protocolo a que se propuseram os encontros de formação. Podemos dizer também que o curso atingiu parte da expectativa esperada ao evidenciar transmitir um conhecimento concreto sobre o protocolo IRDI, já que os profissionais foram capazes de 
compreender as instruções quanto ao protocolo e reproduzirem para os pais no momento em convidá-los a participar do seguimento.

Considerando as respostas em que os profissionais tiveram dificuldade e muita dificuldade, temos: 1- conciliar a aplicação do protocolo e o trabalho na unidade $(37,5 \%$ e $6,3 \%$, seguidamente), 2- acompanhar as famílias e os bebês durante 18 meses (12,5\% e 25\%) e 3- ter apoio de superiores e outros funcionários (25\% e 12,5\%). Nesses mesmos aspectos, a percentagem de profissionais que consideraram nenhuma e pouca dificuldade foram: 1- 37,5\% e $18,8 \% ; 2-43,8 \%$ e $18,8 \% ; 3-43,8 \%$ e $18,8 \%$, respectivamente.

Esses três aspectos em que aparecem as dificuldades em usar o IRDI não deixam de estar correlacionados e podem ser interpretados a partir de 2 âmbitos. O primeiro diz respeito a aspectos práticos, como mudanças de endereço dos pacientes e de serviço por parte dos profissionais; pragmatismo que envolve a unidade básica de saúde, como a rotina de trabalho que deve ser seguida; a ausência de profissionais ou a diminuição do quadro de funcionários, como ocorrido em algumas unidades, além da não consideração de que o profissional formado para utilizar o IRDI nem sempre realiza o atendimento de enfermagem (AE) tendo rotinas distintas na unidade.

O segundo refere-se ao sentido que o protocolo IRDI teve para os profissionais formados, sendo que isso influencia no seu uso ou não e também na maneira de usá-lo. A partir dos dados evidenciados em monitoria, podemos dizer que inicialmente a formação para uso do IRDI não contribuiu para que o profissional apresentasse uma grande mudança na sua postura frente ao bebê, os itens do protocolo eram usados e interpretados pelos profissionais como os aspectos que eles já estavam acostumados a investigar, achavam que o IRDI era muito semelhante ao protocolo institucional que avalia o desenvolvimento apenas pela via do bebê e não considera sua interação com o cuidador, como propõe o IRDI, o que pode tornar conclusiva a hipótese de que a transmissão do protocolo não ocorre apenas pela formação concreta do uso do protocolo. Boa aula sobre os itens e instrução de uso do protocolo podem esclarecê-los, mas isto não é suficiente para que na prática o protocolo seja incorporado na rotina de trabalho e adquira o apoio institucional que necessita. Mas, então, o que mais se faz necessário para a transmissão de um protocolo que se propõe a "ler" a constituição subjetiva do bebê? 
Essa é uma questão complexa, que pode ser respondida a partir de diversos âmbitos. A seguir, apresentaremos vários estudos realizados para evidenciarmos o conhecimento adquirido pelos profissionais, seguidos de discussões advindas do campo em que esse trabalho de educação permanente se deu. Por fim, discutiremos mais os sentidos da formação e do uso do IRDI, entrando em cena a importância das monitorias, que se constituiu como um espaço de escuta das mais diversas interações. Interações dos participantes com a monitora, com seus próprios familiares, com seus colegas de trabalho e supervisores, com seus trabalhos, com os pacientes assistidos, enfim, com tudo que pôde ser carregado de subjetividade.

\subsection{Resultados obtidos com as questões fechadas}

As fichas de acompanhamento foram estruturadas com questões fechadas baseadas no protocolo IRDI. A escolha de determinado indicador para embasar uma pergunta foi aleatória; não havíamos pensado em selecionar algum aspecto específico, apenas em delimitar o número de

perguntas para que o questionário não fosse extenso. Com isso, tivemos diretamente 3 indicadores na primeira ficha de acompanhamento e 4 na segunda ficha; demais perguntas se referiam aos fundamentos do protocolo.

As perguntas fechadas nas duas fichas de acompanhamento indagavam sobre conteúdos que ainda seriam tratados no curso de formação. Eram questões com fundamentos antecipatórios ao curso e acreditávamos que assim seria uma maneira de verificar em que medida os profissionais já achavam importantes os aspectos do desenvolvimento abordados.

A primeira ficha de acompanhamento (Apêndice D), respondida por 43 profissionais de saúde antes do primeiro encontro, ocorrido em janeiro de 2011, (4 enfermeiros e 29 auxiliares de enfermagem), teve duas partes: a primeira totalizou 5 questões fechadas, apresentadas como afirmações em sequência randomizada, com as seguintes possibilidades de resposta, em escala de Likert: concordo fortemente, concordo, discordo e discordo fortemente. Com essas quatro possibilidades de respostas, não teríamos como compará-las de maneira altamente significativa, devido ao cluster baixo. Então, agrupamos no conjunto das respostas obtidas com "concordo" 
aquelas obtidas como "concordo fortemente"; o mesmo foi realizado com "discordo" e "discordo fortemente", com a finalidade de aumentar o poder comparativo dos clusters resultantes.

\subsubsection{Resultados da Primeira Ficha de Acompanhamento}

Na sequência, apresentamos os resultados de 3 questões aplicadas antes da primeira formação (janeiro/2011) e foram realizadas apenas nesse momento. Os resultados das outras 2 questões, realizadas nessa ficha, serão apresentados mais adiante, pois aparecem também na ficha de acompanhamento que antecedeu o segundo momento da formação (março/2011).

As 3 perguntas apresentadas na sequência foram criadas a partir de indicadores do IRDI e tinham como resposta correta a opção concordo:1- No meu trabalho, quando estou com um bebê, levo em conta como ele interage com as pessoas ao seu redor; 2- É fundamental para o desenvolvimento do bebê que a mãe o ajude tentando entender o que ele quer quando chora ou grita; 3- Se o bebê quase nunca tenta olhar para a mãe, mesmo se ela chamar sua atenção, ele pode estar com alguma dificuldade de desenvolvimento. As respostas esperadas corretas foram sinalizadas em cada tabela abaixo em itálico e negrito.

Apresentamos na sequência as respostas obtidas na primeira pergunta sobre a consideração da interação estabelecida entre o bebê os demais, para o desenvolvimento infantil.

Tabela 5 - No meu trabalho, quando estou com um bebê, levo em conta como ele interage com as pessoas ao seu redor.

\begin{tabular}{lcc|cc}
\hline & \multicolumn{2}{c|}{ Enfermeiros } & \multicolumn{2}{c}{ Auxiliares de Enfermagem } \\
\hline Concordo & $\mathbf{N}$ & $\%$ & $\mathbf{N}$ & $\%$ \\
Discordo & $\mathbf{1 3}$ & $\mathbf{9 2 , 9}$ & $\mathbf{2 9}$ & $\mathbf{1 0 0}$ \\
TOTAL & 1 & 7,1 & 0 & 100 \\
\hline A & 14 & 100 & 29 & 0 \\
\hline
\end{tabular}

A maioria dos enfermeiros $(92,9 \%)$ e todos os auxiliares de enfermagem (100\%) - como representado na tabela 2 - levam em conta se um bebê de até 4 meses interage com outras 
pessoas, evidenciando que os profissionais de saúde consideram os aspectos relacionais ao avaliarem os bebês que acompanham. Pode-se dizer também que há uma equivalência entre a prática de enfermeiros e de auxiliares ao verificarem esse aspecto.

O primeiro item do IRDI faz menção a um aspecto da mãe em saber, ou melhor, em supor o que o bebê quer quando chora ou grita. Formulamos uma afirmação quanto a esse item com o objetivo de verificarmos se essa era uma preocupação anterior à formação.

Tabela 6 - É fundamental para o desenvolvimento de um bebê de até 4 meses que a mãe o ajude tentando entender o que ele quer quando chora ou grita.

\begin{tabular}{lcc|cc}
\hline & \multicolumn{2}{c|}{ Enfermeiros } & \multicolumn{2}{c}{ Auxiliares de Enfermagem } \\
\hline Concordo & $\mathbf{N}$ & $\%$ & $\mathbf{N}$ & $\%$ \\
Discordo & $\mathbf{1 4}$ & $\mathbf{1 0 0}$ & $\mathbf{2 7}$ & $\mathbf{9 3 , 1}$ \\
TOTAL & 0 & 0 & 2 & 6,9 \\
& 14 & 100 & 29 & 100 \\
\hline
\end{tabular}

Conforme mostra a tabela acima, os 14 enfermeiros (100\%) que participaram da primeira etapa da formação acreditam que esse comportamento da mãe seja fundamental para o desenvolvimento do bebê. A maioria dos auxiliares de enfermagem (93,1\%) também concorda.

Outro item da primeira faixa do IRDI é o indicador 5: "há troca de olhares entre o bebê e a mãe/cuidador”. Indagamos os participantes da formação com a finalidade de verificarmos se a troca de olhares entre criança e cuidadores está dentro do escopo de atenção deles e se consequentemente consideram esse aspecto importante para o desenvolvimento infantil.

Tabela 7 - Um bebê de até 4 meses pode estar com alguma dificuldade de desenvolvimento se ele quase nunca tenta olhar para a mãe, mesmo se ela chamar sua atenção.

\begin{tabular}{lcc|cc}
\hline & \multicolumn{2}{c|}{ Enfermeiros } & \multicolumn{2}{c}{ Auxiliares de Enfermagem } \\
\hline Concordo & $\mathbf{N}$ & $\mathbf{\%}$ & $\mathbf{N}$ & $\mathbf{9}$ \\
Discordo & $\mathbf{1 3}$ & $\mathbf{9 2 , 9}$ & $\mathbf{2 7}, \mathbf{1}$ \\
TOTAL & 1 & 7,1 & 2 & 6,9 \\
& 14 & 100 & 29 & 100 \\
\hline
\end{tabular}


Na tabela 7, nota-se que 92,9\% dos enfermeiros e 93,1\% dos auxiliares de enfermagem praticamente não havendo desacordo entre eles - consideram a troca de olhares importante para o desenvolvimento do bebê, indicando também uma preocupação com a relação entre o bebê e seus familiares.

A partir desses resultados, observamos que a qualidade da interação do bebê com os demais (enfermeiros $92,9 \%$ e auxiliares $100 \%$ ), a suposição materna de que o bebê seja um ser desejante (enfermeiros $100 \%$ e auxiliares $93,1 \%$ ) e a troca de olhares entre o cuidador e o bebê (enfermeiros 92,9\% e auxiliares 93,1\%), foram assuntos altamente considerados pelos profissionais que raramente negaram a importância desses conteúdos para o desenvolvimento infantil. Esses itens, em proporções diferentes, consideram a relação entre o bebê e seus cuidadores, e possivelmente inclinam o profissional em alguma medida a focar nesses aspectos em sua prática, mas não podemos afirmar que essa seja necessariamente a atuação dos profissionais participantes do curso.

Podemos dizer, entretanto, que parece que esses profissionais já estavam - anteriormente à formação - familiarizados e sensibilizados para fatores subjetivos, reconhecendo a importância desses para o desenvolvimento infantil. Veremos mais adiante se os dados da monitoria confirmam ou não essa tendência. 


\subsubsection{Resultados da Segunda Ficha de Acompanhamento}

Antes do segundo encontro de formação, entregamos uma nova ficha de acompanhamento (Apêndice E), respondida pelos 33 profissionais presentes, sendo 10 enfermeiras e 23 auxiliares de enfermagem. Nessa ficha investigamos aspectos do desenvolvimento de um bebê de até 8 meses, relacionados aos itens da segunda faixa do IRDI - de 4 a 8 meses incompletos.

As questões realizadas foram: 1- Em relação ao desenvolvimento de um bebê de até oito meses, não importa se ele dorme mais de dia do que de noite; 2- É um sinal de bom desenvolvimento quando o bebê utiliza vocalizações ou gestos diversos para se expressar em diferentes ocasiões; 3- É importante prestar atenção se o bebê é ativo, pedindo ajuda da mãe ou de outra pessoa quando precisa e se, ao chorar, gritar ou resmungar, aguarda um pouco pela resposta de quem ele chamou; 4- Ao acompanhar o desenvolvimento de um bebê, observo se a mãe ou cuidador fala com ele, perguntando ou contando o que está acontecendo, bem como as reações do bebê a essa conversa.

As tabelas a seguir, mostram resultados dessas 4 afirmações realizadas apenas nesse momento, tendo a primeira pergunta como resposta correta a opção discordo e demais tendo concordo como a alternativa correta.

O IRDI 6 averigua se o bebê consegue diferenciar o dia da noite e se, portanto, está incorporando o ritmo do ambiente familiar, utilizando o sono como parâmetro. Indagamos se o turno de sono de um bebê de até 8 meses é indiferente para seu desenvolvimento. Seguem resultados.

Tabela 8 - Em relação ao desenvolvimento de um bebê de até 8 meses, tanto faz se ele dorme mais de dia do que de noite.

\begin{tabular}{lcc|cc}
\hline & \multicolumn{2}{c|}{ Enfermeiros } & \multicolumn{2}{c}{ Auxiliares de Enfermagem } \\
\hline & $\mathbf{N}$ & $\%$ & $\mathbf{N}$ & $\%$ \\
Concordo & 0 & 0 & 1 & 4,3 \\
Discordo & $\mathbf{1 0}$ & $\mathbf{1 0 0}$ & $\mathbf{2 2}$ & $\mathbf{9 5 , 7}$ \\
TOTAL & 10 & 100 & 23 & 100 \\
\hline
\end{tabular}


A tabela 8, mostra que todos os enfermeiros (100\%) discordaram da afirmação, defendendo a importância dos momentos noturnos de sono. 95,7\% dos auxiliarem de enfermagem, também discordam da afirmação, praticamente não havendo discordância entre os dois cargos nessa questão.

O indicador 7, da segunda faixa do IRDI, investiga se a criança expressa suas necessidades com sinais diferentes para cada ensejo, dando entrada ao universo das distinções e tornando complexas as maneiras de enunciar seus pedidos. Apresentamos os resultados na tabela 6 .

Tabela 9 - É bom sinal de desenvolvimento quando o bebê utiliza vocalizações ou gestos diversos para se expressar em diferentes ocasiões.

\begin{tabular}{lcc|cc}
\hline & \multicolumn{2}{c|}{ Enfermeiros } & \multicolumn{2}{c}{ Auxiliares de Enfermagem } \\
\hline Concordo & $\mathbf{N}$ & $\mathbf{\%}$ & $\mathbf{N}$ & $\mathbf{1 0 0}$ \\
Discordo & $\mathbf{9}$ & $\mathbf{9 0}$ & $\mathbf{2 3}$ & 0 \\
TOTAL & 1 & 10 & 0 & 100 \\
\hline
\end{tabular}

Conforme tabela acima, 90\% dos enfermeiros e 100\% dos auxiliares de enfermagem concordam que as expressões dos bebês devem se sofisticar e que isso evidencia bom sinal de desenvolvimento.

Na segunda faixa do protocolo IRDI temos o indicador 8, que investiga se o bebê pede ajuda sem ficar passivo e se, ao demandar atenção, aguarda a resposta de seus cuidadores. Seguem resultados na tabela a seguir. 
Tabela 10 - É importante prestar atenção se o bebê é ativo, pedindo ajuda da mãe ou de outra pessoa quando precisa e se, ao chorar, gritar ou resmungar, aguarda um pouco pela resposta de quem ele chamou.

\begin{tabular}{lcc|cc}
\hline & \multicolumn{2}{c|}{ Enfermeiros } & \multicolumn{2}{c}{ Auxiliares de Enfermagem } \\
\hline Concordo & $\mathbf{N}$ & $\%$ & $\mathbf{N}$ & $\%$ \\
Discordo & $\mathbf{1 0}$ & $\mathbf{1 0 0}$ & $\mathbf{2 3}$ & $\mathbf{1 0 0}$ \\
TOTAL & 0 & 0 & 0 & 100 \\
\hline
\end{tabular}

Observamos que todos os enfermeiros, assim como todos os auxiliares de enfermagem, acham importante observar se um bebê de 8 meses solicita e consegue esperar seus cuidadores, sem desacordo entre os profissionais.

O item 9 do IRDI explora se os cuidadores de um bebê de até 8 meses conversam com ele, dirigindo-lhe pequenas frases, estabelecendo comunicação com o bebê e como o bebê reage a isso, apresentamos as repostas obtidas quanto esse aspecto na tabela abaixo.

Tabela 11 - Ao acompanhar o desenvolvimento de um bebê, observo se a mãe ou cuidador fala com ele, perguntando ou contando o que está acontecendo, bem como as reações do bebê a essa conversa.

\begin{tabular}{lcc|cc}
\hline & \multicolumn{2}{c|}{ Enfermeiros } & \multicolumn{2}{c}{ Auxiliares de Enfermagem } \\
\hline Concordo & $\mathbf{N}$ & $\%$ & $\mathbf{N}$ & $\%$ \\
Discordo & $\mathbf{9}$ & $\mathbf{9 0}$ & $\mathbf{2 3}$ & $\mathbf{1 0 0}$ \\
TOTAL & 1 & 10 & 0 & 0 \\
& 10 & 100 & 23 & 100
\end{tabular}

Conforme representado na tabela 11, a grande maioria dos enfermeiros (90\%) e todos os auxiliares de enfermagem $(100 \%)$ afirmam avaliar a comunicação entre mãe e bebê ao acompanhar o desenvolvimento da criança.

As quatro primeiras perguntas da segunda ficha de acompanhamento mostram que tanto os enfermeiros como os auxiliares de enfermagem apresentam um grau de coincidência das respostas com fundamentos e indicadores do IRDI bastante alto. Evidenciando que esses 
profissionais quase não discordaram das afirmações realizadas e provavelmente consideram importantes os seguintes aspectos abordados nesse questionário: turnos de sono do bebê, indicando uma diferenciação entre noite e dia por parte do bebê; vocalizações do bebê; bebê é ativo, mas alterna suas demandas com momentos de espera; e presença de comunicação dos cuidadores com seus bebês.

De maneira geral, também há um consenso entre enfermeiros e auxiliares de enfermagem nas respostas apresentadas, parece que o cargo e a formação prévia não têm influenciado tanto nesses aspectos.

\subsubsection{Comparação dos resultados da Primeira e da Segunda Ficha de Acompanhamento}

As tabelas a seguir comparam dois diferentes momentos da aplicação de 2 perguntas que foram realizadas nas fichas de acompanhamento de janeiro e março, são elas: 1- Para o desenvolvimento do bebê, tanto faz se a mãe fala com ele de maneira especialmente carinhosa ou não; 2- A saúde orgânica do bebê é suficiente para seu desenvolvimento como ser humano. Essas 2 perguntas tinham como resposta esperada a opção discordo e foram realizadas em 2 momentos (ficha 1 e 2), porque o índice de acerto foi menor que nas demais perguntas apresentadas. As respostas obtidas na ficha 1 e 2 foram comparadas.

A primeira pergunta baseou-se no item 2 do IRDI, que investiga se a mãe fala com o bebê em estilo particular, usando o manhês ${ }^{11}$. Seguem resultados na tabela a seguir.

\footnotetext{
${ }^{11}$ Manhês (motherese, em inglês) é o nome dado a vocalizações específicas dos adultos dirigidas aos bebês, que apresentam mudanças de ritmo e entonações da fala, prolongamentos de vogais e uso de diminutivos.
} 
Tabela 12 - Para o desenvolvimento do bebê, tanto faz se a mãe fala com ele de maneira especialmente carinhosa ou não. $\mathbf{N}$ e (\%)

\begin{tabular}{lcc|cc}
\hline & \multicolumn{2}{c}{ Janeiro/2011 } & \multicolumn{2}{c}{ Março/2011 } \\
\hline \multirow{2}{*}{ Concordo } & $1(7,1 \%)$ & $7(24,1 \%)$ & $0(0 \%)$ & $1(4,3 \%)$ \\
Discordo & $\mathbf{1 3 ( 9 2 , 9 \% )}$ & $\mathbf{2 2 ( 7 5 , 9 \% )}$ & $\mathbf{1 0}(\mathbf{1 0 0 \% )}$ & $\mathbf{2 2 ( 9 5 , 7 \% )}$ \\
TOTAL & $14(100 \%)$ & $29(100 \%)$ & $10(100 \%)$ & $23(100 \%)$ \\
\hline
\end{tabular}

Em janeiro de 2011, conforme tabela 12, a maioria dos enfermeiros (92,9\%) afirmou que o manhês é importante para o desenvolvimento do bebê, destoando dos auxiliares de enfermagem representados em 75,9\%. Em março de 2011 todos os enfermeiros (100\%) afirmaram a importância desse aspecto e 95,7\% dos auxiliares de enfermagem também, aumentando a aproximação de concepções sobre o manhês entre os dois grupos. O único enfermeiro que respondeu concordo do fundamento em janeiro mudou para discordo em março. E dos $24,1 \%$ dos auxiliares de enfermagem que responderam concordo em janeiro, 4 (57,1\%) mudaram para discordo em março e $3(42,9 \%)$ não compareceram ao segundo encontro.

Ao analisarmos essa afirmação, verificamos que em janeiro tivemos uma margem de respostas não coincidentes com o IRDI $(24,1 \%)$ entre os auxiliares de enfermagem, que não se manteve em março (4,3\%), destoando dos enfermeiros que apresentaram não coincidência em 7,1\% em janeiro e $0 \%$ em março. Dos 8 profissionais de saúde que não coincidiram em janeiro, 5 (62,5\%) passaram a coincidir em março, o que parece ser um efeito positivo da formação. Somente um profissional, cuja resposta havia coincidido em janeiro, mudou de posição em março. Levando em conta que a reposta coincidente era discordo, o que demanda mais atenção para compreensão da pergunta e aumenta as chances de confusões, podemos pensar que houve desatenção ou falta de clareza da pergunta.

A segunda pergunta aplicada nas 2 fichas de acompanhamento, conforme mostra tabela abaixo, indagava se a saúde orgânica do bebê é suficiente para seu desenvolvimento como ser humano, e objetivava investigar se diferentes perspectivas envolvidas no desenvolvimento infantil, como aspectos biológicos, neurológicos e emocionais eram considerados pelos profissionais. 
Tabela 13 - A saúde orgânica do bebê é suficiente para seu desenvolvimento como ser humano.

\begin{tabular}{lcc|cc}
\hline & \multicolumn{2}{c}{ Janeiro/2011 } & \multicolumn{2}{c}{ Março/2011 } \\
\hline Enfermeiros & Auxiliares & Enfermeiros & Auxiliares \\
Discordo & $0(0 \%)$ & $9(31 \%)$ & $2(20 \%)$ & $5(21,7 \%)$ \\
TOTAL & $\mathbf{1 4}(\mathbf{1 0 0 \% )}$ & $\mathbf{2 0}(\mathbf{6 9 \% )}$ & $\mathbf{8 ( 8 0 \% )}$ & $\mathbf{1 8 ( 7 8 , 3 \% )}$ \\
& $14(100 \%)$ & $29(100 \%)$ & $10(100 \%)$ & $23(100 \%)$ \\
\hline
\end{tabular}

Em janeiro de 2011, como representado na tabela 13, 100\% dos enfermeiros e 69\% dos auxiliares de enfermagem discordaram da afirmação que o aspecto orgânico é suficiente para que o bebê se desenvolva como ser humano. Em março desse mesmo ano, os enfermeiros discordaram da afirmação em $80 \%$ e as auxiliares de enfermagem em 78,3\%, quase não havendo desacordo entre eles nesse momento. Dois enfermeiros (20\%) que responderam de forma coincidente com o IRDI em janeiro mudaram de posição em março. De cinco auxiliares de enfermagem $(21,7 \%)$ que não responderam de forma coincidente com o IRDI em março, dois (40\%) haviam respondido coincidentemente em janeiro e três (60\%) mantiveram a discordância. E de $31 \%$ de auxiliares de enfermagem que não responderam de forma coincidente com o IRDI em janeiro, 3 (33,3\%) continuaram fazendo-o em março, $4(44,4 \%)$ mudaram de posição e 2 (22,2\%) não compareceram ao segundo encontro.

Quando analisamos a importância dada a esse aspecto, observamos que a princípio, em janeiro, há uma discrepância quanto às respostas coincidentes dos enfermeiros (100\%) e dos auxiliares de enfermagem (69\%). Em março essa distância diminuiu para 80\% (enfermeiros) e 78,3\% (auxiliares). Se compararmos os dois períodos entre os enfermeiros, os dados apresentam uma queda de $100 \%$ de coincidências em janeiro para $80 \%$ em março, o que não ocorre entre os auxiliares. Analisamos, também, as repostas não coincidentes e verificamos que $4(44,4 \%)$ dos auxiliares que não coincidiram em janeiro passaram a coincidir em março, o que pode ser considerado consequência da formação; e 3 (33,3\%) mantiveram a não coincidência. Em março, 2 enfermeiros (20\%) e 2 auxiliares de enfermagem (40\%) não coincidiram a resposta, mas haviam coincidido em janeiro, o que nos leva a pensar que houve dificuldade de entendimento da pergunta. Alguns profissionais chegaram a perguntar no momento do preenchimento da ficha de 
acompanhamento o que significava: "saúde orgânica", evidenciando que a pergunta não estava clara e que nem todos a compreenderam.

Os resultados apresentados evidenciaram que os profissionais de enfermagem atribuíam grande importância a diferentes aspectos do desenvolvimento infantil anteriormente à formação. $\mathrm{Na}$ primeira ficha de acompanhamento, obtivemos $100 \%$ dos enfermeiros e $69 \%$ dos auxiliares de enfermagem afirmando que a saúde orgânica não é suficiente para o desenvolvimento do bebê como ser humano.

Na primeira ficha realizamos cinco questões, sendo que em duas delas a escolha coincidente com o IRDI seria discordo. Chamou-nos a atenção o fato dessas questões serem justamente as que tiveram menor número de coincidências, podendo significar uma tendência dos participantes em concordar com as afirmações das fichas de acompanhamento e uma dificuldade em achar que a afirmação teria a escolha discordo como alternativa correta. Parece ser mais fácil concordar com as afirmações e supostamente com quem cria o questionário e realiza o curso de formação. Mas não podemos realizar muitas análises, pois o que nos permitiu estabelecer comparações foram apenas 2 perguntas fechadas e questões abertas repetidas nas 4 fichas de acompanhamento, deixando maiores interpretações para itens que investigam aspectos que focam mais em características pessoais e particulares, como as práticas habituais das profissionais e seus sentidos, mais bem observados nas questões abertas e em monitorias.

Esses dados nos fizeram refletir sobre a construção desses questionários, assim como do método utilizado. Como parametrizar os efeitos de tal formação? Qual seria o método de investigação que melhor consideraria o problema de pesquisa? O método atual tem respondido a nossa pergunta? A partir desses questionamentos redesenhamos a pesquisa: fizemos um estudo com um grupo controle, comparando-o com os profissionais de saúde que participaram dos 4 encontros de formação IRDI, os resultados desse estudo são apresentados na sequência. 


\subsection{Resultados quantitativos e qualitativos das questões abertas}

Nesse item, apresentamos as análises quantitativas dos estudos comparativos realizados entre os grupos controle e intervenção e também estudos comparativos intragrupo intervenção (resultados obtidos antes, ao longo e após a formação com o grupo intervenção). Essas análises serão apresentadas e discutidas logo na sequência. Dados de monitoria em serviço também contribuíram para a discussão.

\subsubsection{Comparações entre os grupos intervenção e controle}

Iniciamos as análises comparando os resultados obtidos com as mesmas perguntas abertas "na sua prática com bebês de até 4, 8, 12 e 18 meses, a que você costuma ficar atenta” (P1, P2, P3 e $\mathrm{P} 4$, respectivamente) realizadas em dois diferentes grupos. O primeiro, grupo intervenção, passou pela formação IRDI e respondeu as perguntas 3 meses após a finalização das monitorias e o segundo, grupo controle, não sofreu intervenção e teve os dados coletados no mesmo momento que o primeiro, em setembro de 2012, conforme ilustramos no Cronograma da Formação IRDI e da Coleta de Dados, em Método, na página 45.

\subsubsection{Análise de aspectos físicos e psicológicos citados nos grupos intervenção e controle}

Analisamos as respostas do grupo controle e do grupo intervenção (respostas obtidas após 3 meses de encerramento da formação) e realizamos uma comparação entre as citações de aspectos físicos e psicológicos, conforme tabela 14. Nessa primeira verificação trabalhamos apenas com respostas binárias "sim ou não", analisando quantos dos 12 participantes de cada grupo mencionam os aspectos citados. 
Tabela 14 - Comparação entre o grupo intervenção e grupo controle de citações de aspectos físicos e psicológicos, em número e percentagem.

\begin{tabular}{|c|c|c|c|c|c|c|}
\hline & \multicolumn{2}{|c|}{ Grupo intervenção } & \multicolumn{2}{|c|}{ Grupo Controle } & \multicolumn{2}{|c|}{ Diferença } \\
\hline & $\begin{array}{l}\text { Aspectos } \\
\text { Físicos }\end{array}$ & $\begin{array}{c}\text { Aspectos } \\
\text { Psicológicos }\end{array}$ & $\begin{array}{l}\text { Aspectos } \\
\text { Físicos }\end{array}$ & $\begin{array}{c}\text { Aspectos } \\
\text { Psicológicos }\end{array}$ & $\begin{array}{l}\text { Aspectos } \\
\text { Físicos }\end{array}$ & $\begin{array}{c}\text { Aspecto } \\
\text { Psicológico }\end{array}$ \\
\hline & $\mathbf{N}(\%)$ & $\mathbf{N}(\%)$ & $\mathbf{N}(\%)$ & $\mathbf{N}(\%)$ & $\%$ & $\%$ \\
\hline $\begin{array}{l}\text { P1 - até } 4 \\
\text { meses }\end{array}$ & $12(100)$ & $11(91,6)$ & $12(100)$ & $0(0)$ & 0 & 91,6 \\
\hline $\begin{array}{l}\mathrm{P} 2-\text { até } 8 \\
\text { meses }\end{array}$ & $11(91,6)$ & $9(75,0)$ & $12(100)$ & $1(8,3)$ & 8,4 & 66,7 \\
\hline $\begin{array}{l}\text { P3 - até } \\
12 \text { meses }\end{array}$ & $11(91,6)$ & $10(83,3)$ & $12(100)$ & $2(16,7)$ & 8,4 & 66,6 \\
\hline $\begin{array}{l}\text { P4 - até } \\
18 \text { meses }\end{array}$ & $12(100)$ & $10(83,3)$ & $12(100)$ & $3(25,0)$ & 0 & 58,3 \\
\hline
\end{tabular}

$\mathrm{Na}$ tabela 14, podemos verificar que praticamente $100 \%$ dos participantes dos dois grupos referem-se aos aspectos físicos ao falar de seus procedimentos de avaliação de bebês em todas as faixas. Quanto às questões emocionais do bebê, as porcentagens de participantes do grupo intervenção que as citaram nas respostas até 4 meses de vida foi de 91,6\%, até 8 meses foi de $75 \%$ e até 12 e 18 meses foi de 83,3\%. No grupo controle, foi respectivamente $0 \%, 8,3 \%, 16,7 \%$ e $25 \%$. As diferenças para tais respostas entre os grupos é de 91,6\%,66,7\%, 66,6\% e 58,3\% para cada faixa.

As comparações entre esses dois grupos nos mostraram efeitos interessantes da formação IRDI. Como era esperado, praticamente todos participantes dos dois grupos mencionaram a avaliação de aspectos físicos do bebê (basicamente procedimentos de puericultura e menção ao desenvolvimento neuropsicomotor), e como nosso objetivo está focado nos aspectos psicológicos iremos nos atentar a eles de maneira mais minuciosa do que nas questões físicas do bebê.

Quanto aos aspectos psicológicos, há grande diferença entre o grupo controle e grupo intervenção. O número de citações dos profissionais formados é relativamente maior: enquanto o grupo controle citou aspectos psicológicos em até $25 \%$ quanto aos bebês de até 18 meses, o grupo 
intervenção atingiu a máxima de $91,6 \%$ da amostra na pergunta referente ao bebê de até 4 meses. Em todas as faixas etárias as menções foram percentualmente maiores no grupo intervenção do que no controle quanto ao âmbito emocional do bebê. Esses dados nos mostram que quem fez a formação tende a considerar mais o desenvolvimento emocional do bebê do que quem não fez. $\mathrm{O}$ grupo intervenção demonstra ter adquirido um conhecimento novo, que pode ser agregado a prática do AE.

A subjetividade do bebê de até 4 meses não foi considerada pelo grupo controle e por 91,6\% dos profissionais formados. Dados de monitoria nos ajudam a entender essa discrepância. Durante as monitorias, notamos um efeito bastante interessante da formação: a descoberta de que há subjetividade no bebê. Muitas delas relataram que a primeira faixa do IRDI, de 0 a 4 meses, foi a que mais as marcou. As participantes se mostraram surpresas, muitas de maneira explícita e outras implicitamente, ao perceberem que não é por puro reflexo que o bebê sorri e balbucia. Elas notaram que num primeiro momento a mãe envolve a subjetividade dela à do bebê, falando com ele em manhês, nomeando o que ele deseja e necessita (a mãe sabe o que ele quer - IRDI-1), e posteriormente o bebê corresponde a isso, respondendo ao manhês (IRDI-3), mantendo o olhar (IRDI-5), oferecendo o pé e a barriga para serem mordidos. A escolha por esses indicadores, para essa explicitação, não foi aleatória; como podemos observar no quadro 4 (página 106), trata-se de indicadores fortemente citados nas resposta as perguntas abertas, evidenciando seu impacto formativo.

Anete $^{12}$ relatou que ficou emocionada ao observar a troca de olhares do bebê com o pai e achou lindo. Quando questionada sobre a importância desse indicador, ela disse que a cena representava que o bebê estava interagindo com o pai, e o bebê demonstrava que gostava dele. Anete se deu conta da forma como um bebê interage com o outro e ainda atribuiu emoção ao ato do bebê. De maneira geral, vimos tanto em dados quantitativos, quanto qualitativos que a formação IRDI possibilitou a descoberta de um bebê carregado de subjetividade que, desde muito cedo, também procura o contato com o outro e "se faz" ser humano.

Visando à credibilidade das análises, essa primeira categorização realizada com os grupos controle e intervenção foi submetida ao teste de confiabilidade Kappa, com os resultados apresentados na sequência:

\footnotetext{
${ }^{12}$ Os nomes utilizados são fictícios, prezando o sigilo das participantes.
} 
Tabela 15 - Grau de concordância obtido no teste Kappa quanto a categorização das respostas em físicas e psicológicas dos grupos intervenção e controle.

\begin{tabular}{lcc}
\hline & Aspectos Físicos & Aspectos Psicológicos \\
\hline P1 - até 4 meses & - & 0,753 \\
P2 - até 8 meses & - & 0,829 \\
P3 - até 12 meses & 0,736 & 0,768 \\
P4 - até 18 meses & - & 0,750
\end{tabular}

O teste Kappa realizado com as respostas categorizadas pela pesquisadora e aluno de graduação, obteve grau de concordância substancial $(0,75 ; 0,76$ e 0,75) para as faixas etárias até 4 meses, até 12 e até 18 meses, e excelente $(0,82)$ para a faixa de até 8 meses, quanto aos aspectos psicológicos. Quanto a categoria 1- aspectos físicos - obtivemos substancial $(0,73)$ para a faixa até 12 meses e nas demais faixas etárias o grau de concordância foi total. Isso evidencia que há concordância entre a categorização realizada pela pesquisadora e voluntário, indicando que ambos admitem os mesmos critérios ao considerar aspectos físicos e psicológicos.

5.4.1.2 Frequências de citações de aspectos psicológicos nos grupos intervenção e controle

De acordo com nosso objetivo, aprofundamos a análise dos aspectos psicológicos e verificamos com que frequência eles foram citados em cada faixa etária, pelos participantes dos grupos intervenção e controle. Esses dados foram apresentados em números absolutos nos gráficos 8 (grupo controle) e 9 (grupo intervenção). 
Gráfico 8 - Frequência de citações de aspectos psicológicos pelos participantes do grupo controle, em números absolutos.

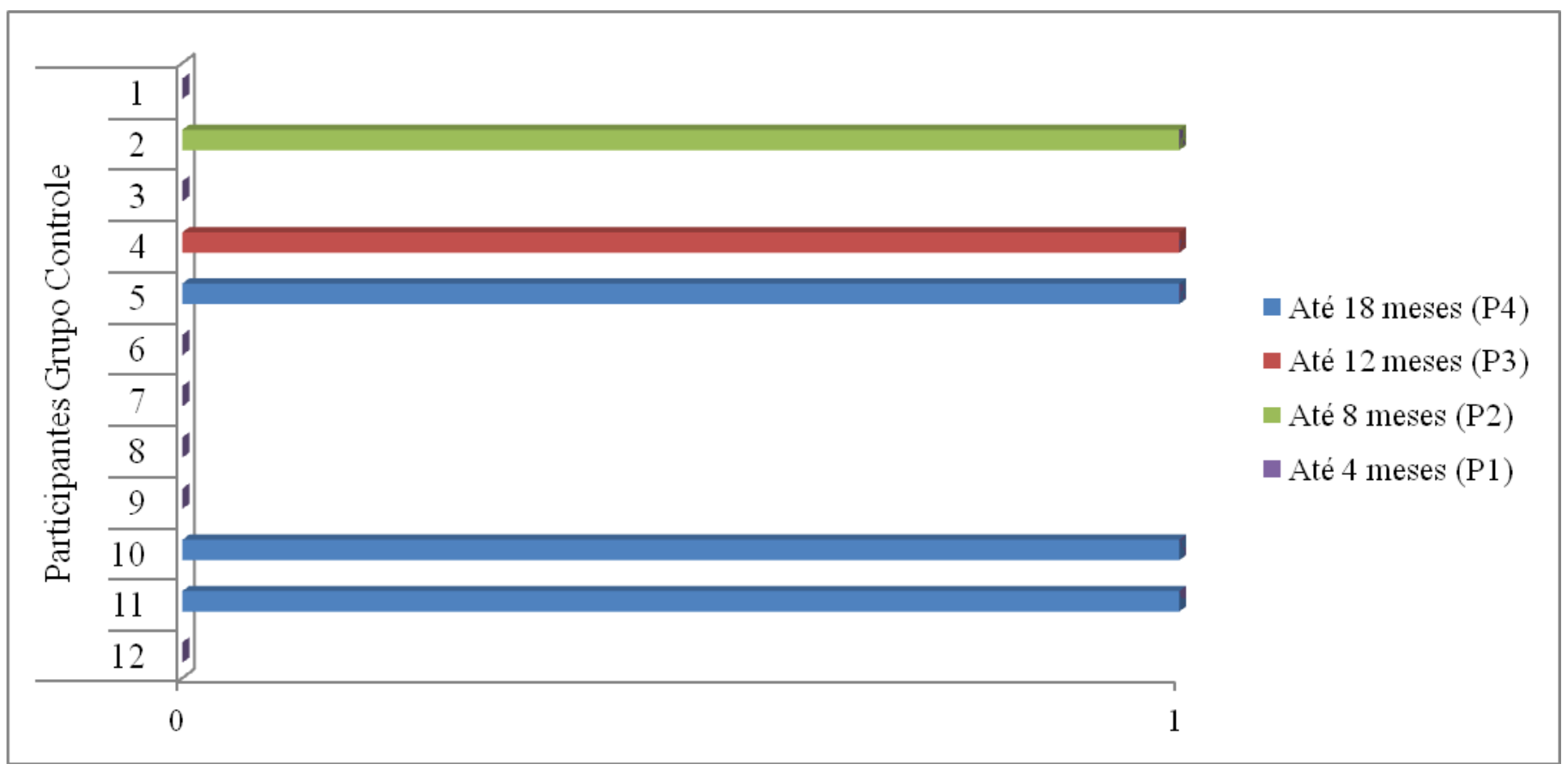

Nesse grupo, notamos poucas citações do aspecto psicológico. Dos 12 participantes, 5 o mencionaram apenas uma vez: 1 participante na faixa de até 8 meses, 1 na de até 12 e 3 na faixa de até 18 meses. Segue gráfico 9 com os resultados do grupo pós-intervenção. 
Gráfico 9 - Frequência de citações de aspectos psicológicos pelos participantes do grupo pósintervenção, em números absolutos.

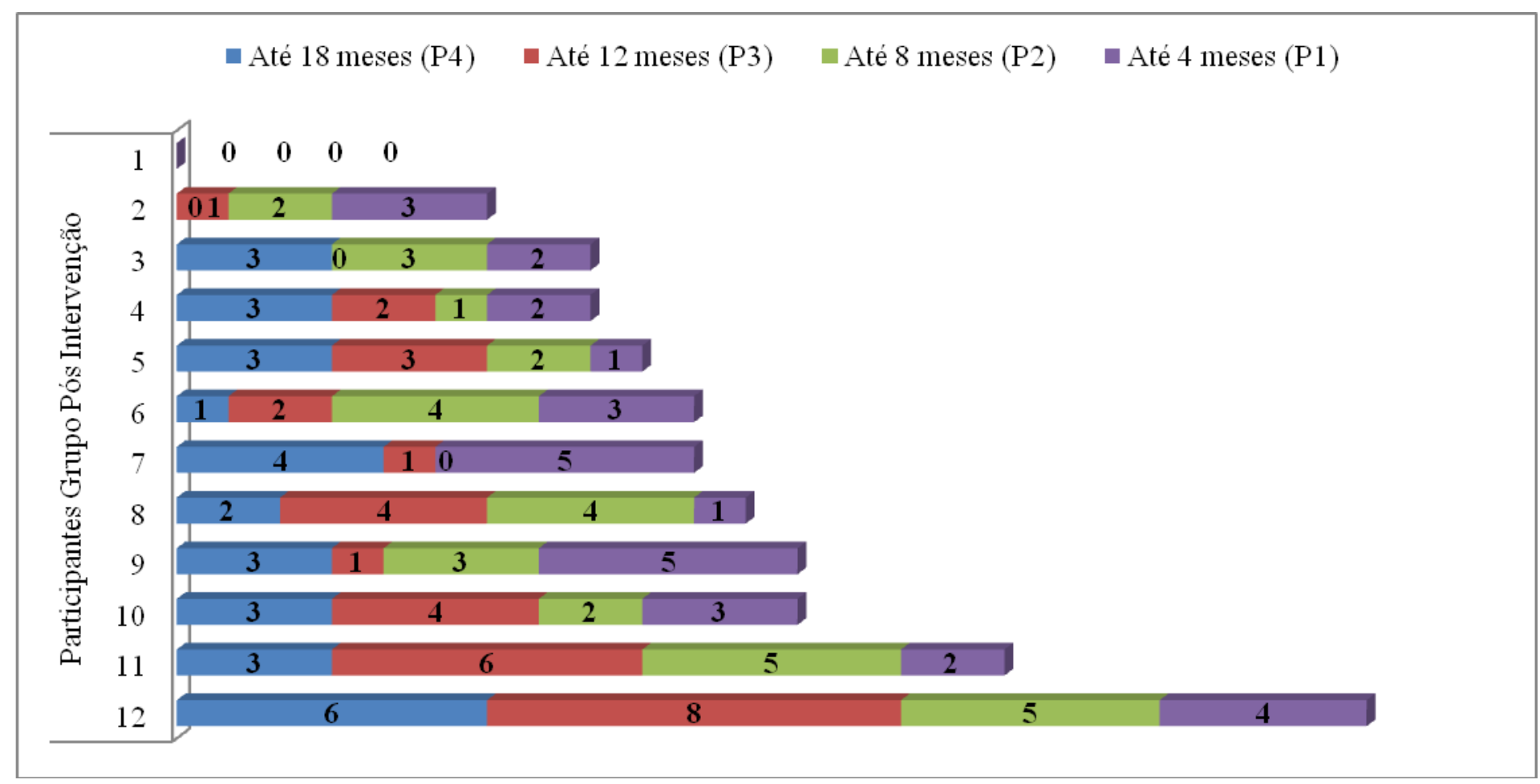

No gráfico 9, apresentamos as frequências de citações de aspectos psicológicos do grupo intervenção (dados obtidos 3 meses após a finalização das monitorias), no qual encontramos uma maior constância e números bem maiores em todas as faixas. Nas faixas etárias de até 4 e até 8 meses $50 \%$ da amostra (6 pessoas) mencionaram de 3 a 5 vezes algum aspecto psicológico do bebê. Na faixa de até 12 meses a variação é maior, pois temos 5 pessoas citando 2 e 1 vez o aspecto psicológico, enquanto outras 5 citam 3, 4, 6 ou 8 vezes esse aspecto. 50\% (6) dos participantes também mencionaram 3 deles na faixa até 18 meses e 1 chegou a citar 4 vezes e outro 6.

Ao comparamos as frequências de citações do grupo controle (gráfico 4) com grupo pósintervenção (gráfico 5) fica evidente a diferença entre ambos. $\mathrm{O}$ grupo que realizou a formação IRDI considera com maior intensidade e constância (uma vez que aparecem citações quase sempre em todas as faixas) os aspectos psicológicos do desenvolvimento do bebê, evidenciando que a formação proposta atingiu seus objetivos. De forma geral, o conhecimento foi transmitido, 
assimilado e parece ter sido consolidado, uma vez que o grupo intervenção apresentou grande menção dos aspectos psicológicos, mesmo após 3 meses de encerramento das monitorias.

Esses mesmos dados, as frequências de respostas adquiridas nos grupos intervenção e controle quanto aos aspectos psicológicos, foram submetidas ao teste Mann-Whitney, que compara as médias obtidas nos 2 grupos. Os resultados são apresentados na tabela 16.

Tabela 16 -Valor P resultante do teste Mann-Whitney entre as amostras independentes grupo intervenção e grupo controle referente a citações de aspectos psicológicos, em cada faixa etária.

\begin{tabular}{lc}
\hline & $\mathrm{P}$ \\
\hline $\mathrm{P} 1$ - até 4 meses & 0,01 \\
$\mathrm{P} 2$ - até 8 meses & 0,01 \\
$\mathrm{P} 3$ - até 12 meses & 0,01 \\
$\mathrm{P} 4$ - até 18 meses & 0,01
\end{tabular}

Obtivemos $\mathrm{p}=0,01$ em todas as faixas etárias, o que evidencia que o grupo de profissionais submetido à formação considera mais os aspectos psicológicos do bebê do que o grupo controle e essa diferença tem pouca chance de ter acontecido devido a um erro amostral $(p=0,01)$.

As frequências visualizadas individualmente (considerando cada participante) nos gráficos 4 e 5 foram somadas e apresentadas por faixas etárias. Na tabela 17, ilustramos, em números absolutos, as ocorrências totais em cada faixa dos grupos intervenção e controle. A diferença entre a comparação dos mesmos também foi evidenciada. 
Tabela 17 - Comparação entre o grupo intervenção e grupo controle quanto ao número total de ocorrências de citações de aspectos psicológicos, em cada faixa etária.

\begin{tabular}{lccc}
\hline Aspectos Psicológicos & Pós-intervenção & Grupo Controle & Diferença N - Aumento (\%) \\
\hline & N & N & N vezes a mais (\%) \\
P1 - até 4 m & 31 & 0 & 31 \\
P2 - até 8 m & 31 & 1 & $30(3000)$ \\
P3 - até $12 \mathrm{~m}$ & 32 & 2 & $30(1500)$ \\
P4 - até $18 \mathrm{~m}$ & 29 & 3 & $26(866,6)$
\end{tabular}

A diferença foi de 31 vezes na questão sobre o bebê de até 4 meses; 30 vezes (diferença de $3000 \%$ ) de citações do aspecto psicológico do grupo intervenção quanto a até 8 meses de vida do bebê; 30 vezes (1500\%), até 12 meses e 26 (866,6\%), até 18 meses.

Além de o grupo intervenção conter um número maior de participantes citando aspectos psicológicos do desenvolvimento do bebê, há também uma maior intensidade, uma vez que a frequência desses aspectos aparece até 31 vezes mais do que no grupo controle. Mesmo diminuindo na última faixa para 26 vezes a mais, grande diferença de citações se manteve nas diferentes faixas etárias da criança, desde 4 meses até 18 meses de idade, quando comparada com o grupo controle. O número expansivo de citações parece indicar que houve uma apreensão de vários âmbitos do aspecto psicológico do bebê e ainda se manteve ao longo do desenvolvimento da criança.

Ainda que consideremos diferentes características existentes entre os profissionais dos grupos intervenção e controle, tais como tempo de trabalho com bebê, formação prévia e idade (apresentadas no capítulo anterior), podemos dizer que as análises expostas até o momento evidenciam efeitos significativos da formação.

Adiante, com as análises intragrupo intervenção, ou seja, realizadas entre diferentes momentos de coletas de dados do mesmo, mostraremos de que maneira e em que intensidade o conhecimento foi sendo adquirido. 
5.4.2 Comparações entre as respostas obtidas pelo grupo intervenção antes, durante e após a formação

Analisaremos nesse momento as respostas dos participantes que passaram por todo processo de formação e preencheram os questionários antes, durante e 3 meses após sua finalização, conforme o Cronograma da Formação IRDI e da Coleta de Dados (página 45, do capítulo Método). As análises intragrupo são compostas sempre pelas respostas dos mesmos 12 profissionais. No entanto, os dados estão desmembrados em 3 momentos: antes e durante a intervenção para os dados coletados anteriormente aos encontros formativos e após a mesma para identificar as respostas obtidas no fim da formação.

5.4.2.1 Análise de aspectos físicos e psicológicos citados pelo grupo intervenção nos três momentos

Primeiramente, as respostas foram separadas em aspectos físicos e psicológicos e verificamos o número de participantes que os citaram em cada momento, conforme os resultados na tabela a seguir. 
Tabela 18 - Comparação de citações de aspectos físicos e psicológicos do grupo intervenção antes e durante intervenção, em número e percentagem.

\begin{tabular}{|c|c|c|c|c|c|c|}
\hline & \multicolumn{2}{|c|}{$\begin{array}{l}\text { Antes e durante a } \\
\text { intervenção }\end{array}$} & \multicolumn{2}{|c|}{ Após a intervenção } & \multicolumn{2}{|c|}{ Diferença (\%) } \\
\hline & $\begin{array}{l}\text { Aspectos } \\
\text { Físicos }\end{array}$ & $\begin{array}{c}\text { Aspectos } \\
\text { Psicológicos }\end{array}$ & $\begin{array}{l}\text { Aspectos } \\
\text { Físicos }\end{array}$ & $\begin{array}{c}\text { Aspectos } \\
\text { Psicológicos }\end{array}$ & $\begin{array}{l}\text { Aspectos } \\
\text { Físicos }\end{array}$ & $\begin{array}{c}\text { Aspecto } \\
\text { Psicológico }\end{array}$ \\
\hline & $\mathbf{N}(\%$ & $\mathbf{N}(\%)$ & $\mathbf{N}(\%)$ & $\mathbf{N}(\%)$ & $\%$ & $\%$ \\
\hline $\mathrm{P} 1$ - até $4 \mathrm{~m}$ & $12(100)$ & $6(50,0)$ & $12(100)$ & $11(91,6)$ & 0 & 41,6 \\
\hline $\mathrm{P} 2$ - até $8 \mathrm{~m}$ & $11(91,6)$ & $8(66,7)$ & $11(91,6)$ & $9(75,0)$ & 0 & 8,3 \\
\hline $\mathrm{P} 3$ - até $12 \mathrm{~m}$ & Não & letado & $11(91,6)$ & $10(83,3)$ & - & - \\
\hline $\mathrm{P} 4$ - até $18 \mathrm{~m}$ & $10(83,3)$ & $8(66,7)$ & $12(100)$ & $10(83,3)$ & 16,7 & 16,6 \\
\hline
\end{tabular}

Como esperado, a maioria relatou aspectos físicos referentes às avaliações de bebês, tanto antes, como após a formação, já que a prática profissional do enfermeiro exige essa consideração.

Com relação aos aspectos psicológicos, temos inicialmente (antes e durante a formação) 50\% do grupo citando-os quanto ao bebê de até 4 meses, 66,7\% até 8 e 18 meses. Esses números aumentaram após a formação para 91,6\% até 4 meses do bebê, 75\% até 8 e 83,3\% até 18 meses, apresentando uma diferença de $41,6 \%, 8,3 \%$ e $16,6 \%$, respectivamente.

Após a formação temos um maior número de profissionais se referindo aos aspectos psicológicos do bebê em todas as faixas etárias da criança. Na primeira faixa etária, até 4 meses de vida do bebê tínhamos inicialmente $50 \%$ do grupo fazendo menção a eles, após a formação esse número sobe para 91,6\%, quase todos os profissionais, praticamente o dobro, passaram a mencionar o desenvolvimento emocional do bebê. Essa faixa etária foi a que mais se diferenciou, tendo as demais faixas um aumento de 8,3\% para bebês de até 8 meses e 16,6\% para os até 18 meses.

Teoricamente, as respostas do grupo controle deveriam coincidir com as do grupo intervenção nos momentos antes e durante os encontros de formação, mas isso não ocorreu. Nossa hipótese é 
a de que possa ter ocorrido um viés metodológico na realização da coleta de dados do grupo intervenção nos momentos antes e durante a formação. As perguntas foram realizadas durante o processo de formação, o que provavelmente pôde ter influenciado nas respostas, além de os questionários, inclusive o primeiro, trazerem questões fechadas que também podem ter contribuído para influenciar as respostas.

No grupo controle, por exemplo, ninguém citou o aspecto psicológico quanto ao bebê de até 4 meses, diferentemente do grupo intervenção antes e durante a formação, quando esse dado foi mencionado em $50 \%$ da amostra. Ao analisarmos os conteúdos das respostas, verificamos que há menção à interação do bebê com familiares e troca de olhares. Esses 2 assuntos foram abordados nas perguntas fechadas, o que fortalece nossa hipótese de que essas puderam influenciar no resultado. $\mathrm{Na}$ ficha utilizada para questionar o grupo controle havia apenas a questão aberta, tornando o dado mais neutro. Na ficha 4 também só havia a questão aberta e a percentagem de participantes citando aspectos psicológicos foi 0 .

5.4.2.2 Frequência de citações de aspectos psicológicos pelo grupo intervenção nos três momentos

Comparamos também as ocorrências de citações dos aspectos psicológicos nas perguntas 1,2 e 4 (referente às faixas etárias de até 4,8 e 18 meses de idade do bebê) entre os resultados do grupo intervenção antes, durante e após a formação. Não foi possível estabelecer comparações quanto aos dados da P3 (até 12 meses), pois a mesma não foi realizada no grupo pré e durante a intervenção. Evidenciamos dados obtidos em cada pergunta P1, P2 e P4, separadamente, nos gráficos seguintes. 
Gráfico 10 - Comparação entre frequências em número absoluto, de aspectos psicológicos citados antes e depois da intervenção, na faixa de até 4 meses de idade do bebê (P1).

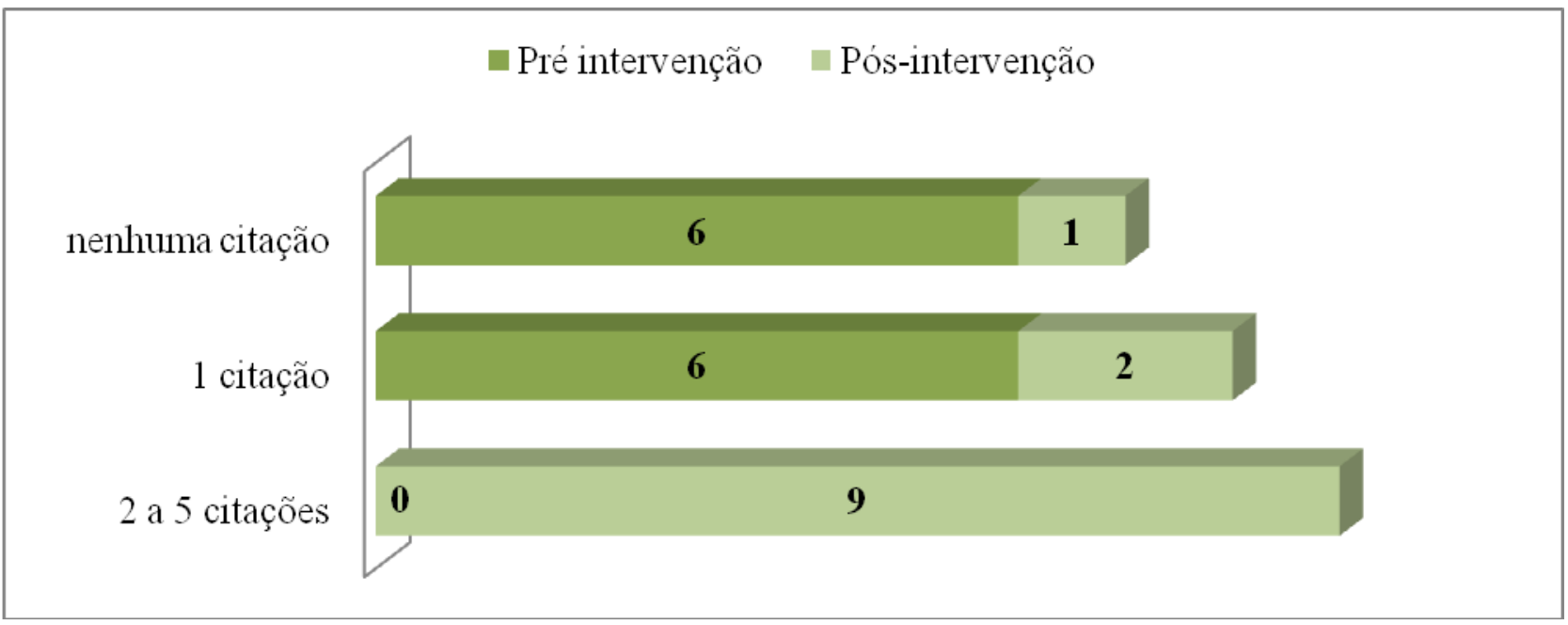

Anteriormente à formação, $6(50 \%)$ dos participantes citaram apenas uma vez algum aspecto psicológico do desenvolvimento do bebê e outros $50 \%$ não o citaram, enquanto após a intervenção esse número passou a ser $2(16,6 \%)$ para os que referiram aspectos psicológicos uma vez e $1(8,4 \%)$ para nenhuma. No após a intervenção, encontramos o número de 2 a 5 citações em $75 \%$ (9) da amostra, o que indica grande aumento de citações após a formação. 2 (16,6\%) participantes após a intervenção ainda citaram uma vez o aspecto psicológico e apenas $1(8,4 \%)$ não o citou.

Vejamos a seguir, no gráfico 11, comparação parecida, no entanto, quanto às respostas dadas para a P2, que considera a segunda faixa etária do bebê, até 8 meses. 
Gráfico 11 - Comparação entre ocorrências em número absoluto, de aspectos psicológicos citados antes e depois da intervenção, na faixa de até 8 meses de idade do bebê (P2).

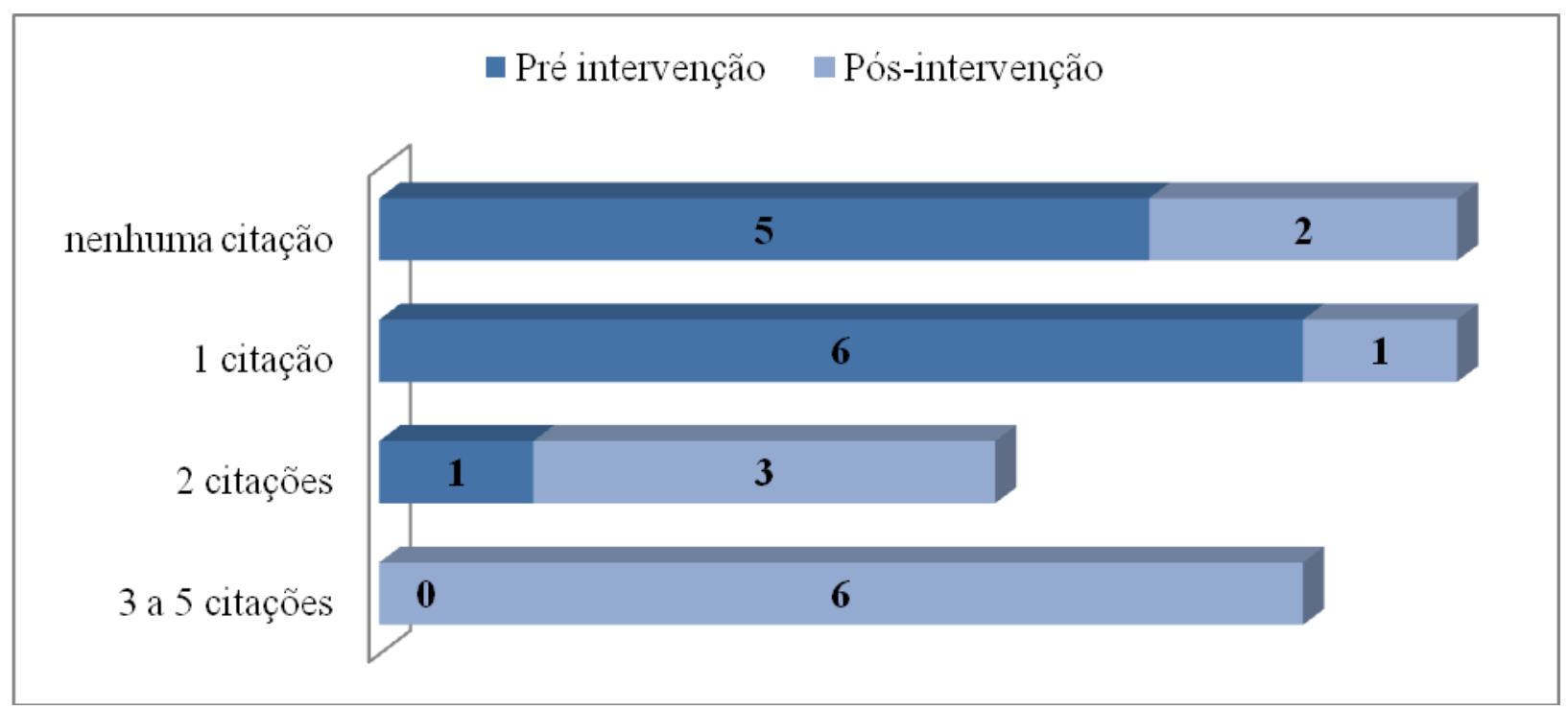

Na faixa de até 8 meses, $6(50 \%)$ participantes referenciaram 1 vez o aspecto psicológico, 5 $(41,6 \%)$ não fizeram menção e $1(8,4 \%)$ faz 2 citações antes e durante a intervenção. Após, 6 (50\%) pessoas mencionaram de 3 a 5 vezes esse aspecto, 3 (25\%) o referenciaram 2 vezes, 2 $(16,6 \%)$ não o mencionaram e $1(8,4 \%)$ fez uma única citação. Esses dados evidenciam que a frequência de menção de aspectos psicológicos é maior no grupo após a intervenção.

Por fim, também apresentamos no gráfico 12 as comparações de frequências dos 2 momentos (antes e durante intervenção X após a intervenção) para as respostas da P4, até 18 meses de idade do bebê. 
Gráfico 12 - Comparação entre ocorrências em número absoluto, de aspectos psicológicos citados antes e depois da intervenção, na faixa de até 18 meses de idade do bebê (P4).

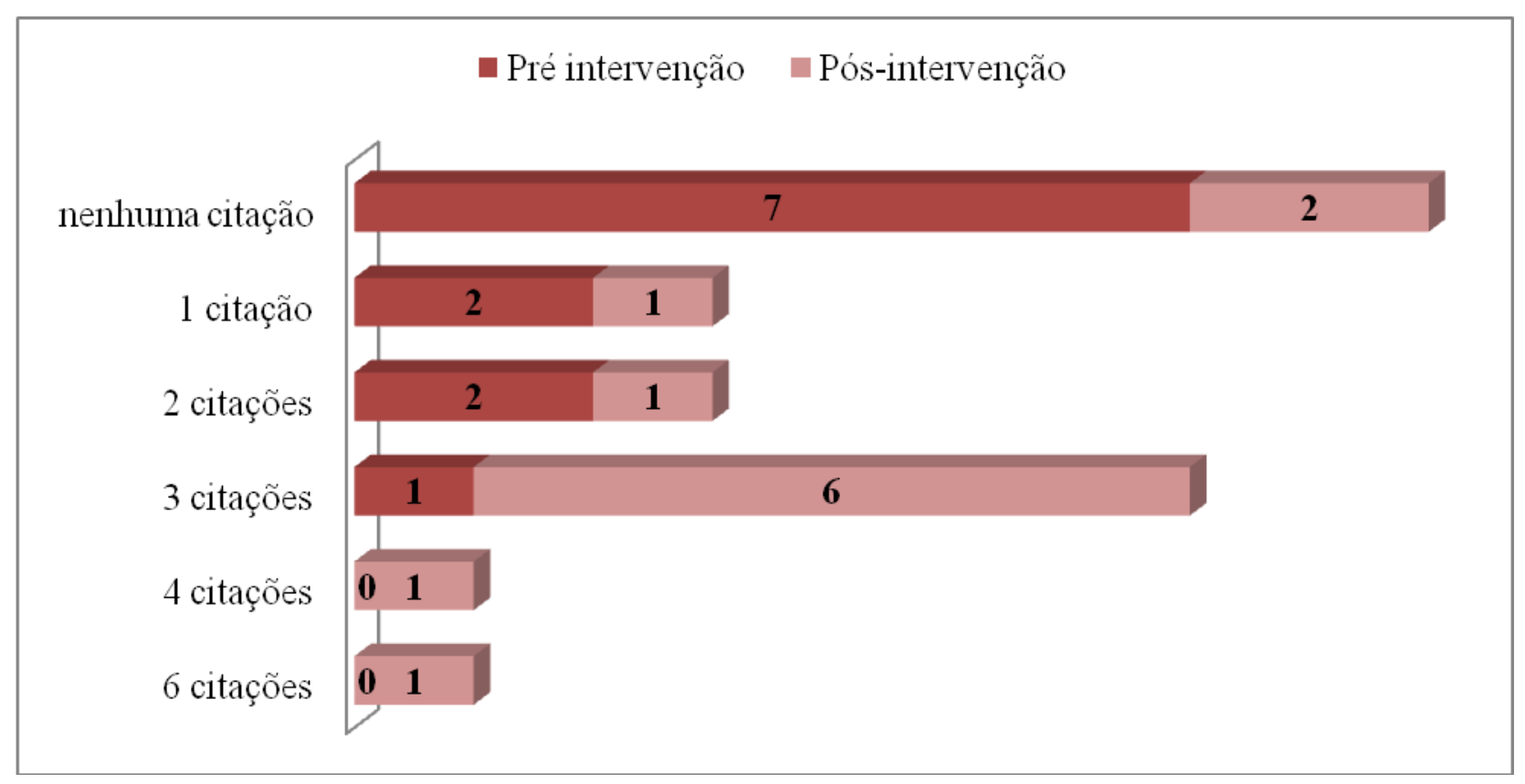

Antes e durante a intervenção, 7 dos participantes $(58,4 \%)$ não fizeram nenhuma menção ao aspecto psicológico na faixa de até 18 meses. 2 (16,6\%) o mencionaram 1 e 2 vezes, e $1(8,4 \%) 3$ vezes. Após a intervenção, a frequência de citações aumenta. 6 (50\%) pessoas da amostra referenciaram 3 vezes o aspecto psicológico. 2 (16,6\%) não o citaram e 1 (8,4\%) fizeram uma única menção e esse mesmo número de participante citaram o aspecto psicológico 2, 4 e 6 vezes.

Quando fazemos a comparação intragrupo das frequências obtidas quanto a aspectos psicológicos nas 3 faixas etárias (P1, P2 e P4) analisadas, observamos maior número de citações após a intervenção, evidenciando que os encontros formativos e as monitorias em serviço tiveram seus efeitos bastante positivos, elevando as considerações dos participantes quanto aos aspectos psicológicos. Lembramos que não foi possível estabelecer comparação com a P3, até 12 meses, pois não coletamos esse dado no grupo antes e durante a intervenção.

Realizamos com essas frequências de citações quanto aos aspectos psicológicos obtidas antes e após a intervenção um teste estatístico que analisa se as alterações entre observações emparelhadas estão diretamente relacionadas à diferença entre a primeira e segunda amostra. Apresentamos na tabela 19 o resultado do teste de Wilcoxon realizado com as frequências obtidas 
nas faixas etárias de até 4, 8 e 18 meses. Lembramos que os participantes são os mesmos e responderam às mesmas perguntas em 2 diferentes momentos: antes e durante intervenção e pósintervenção.

Tabela 19 -Valor P resultante do teste Wilcoxon entre as amostras pareadas de citações de aspectos psicológicos, em cada faixa etária, antes e durante intervenção e após a mesma.

\begin{tabular}{lc}
\hline & $\mathrm{P}$ \\
\hline $\mathrm{P} 1$ - até 4 meses & 0,01 \\
$\mathrm{P} 2$ - até 8 meses & 0,01 \\
$\mathrm{P} 3$ - até 12 meses* & - \\
$\mathrm{P} 4$ - até 18 meses & 0,01 \\
\hline
\end{tabular}

* não foi possível realizar o teste nessa faixa etária, pois os dados não foram coletados no grupo pré e durante intervenção.

O valor p obtido foi - 0,01 nas 3 faixas etárias analisadas, o que indica que as medianas de citações de aspectos psicológicos obtidas após a intervenção são maiores do que as anteriores (antes e durante a intervenção). Portanto, pode ser concluído que as participantes consideram mais as características psicológicas do desenvolvimento de bebês após terem participado da formação e é pouco provável que tal diferença tenha ocorrido por erro amostral.

Comparamos também, entre os diferentes momentos, a somatória de todas as citações (frequências) de aspectos psicológicos realizadas em cada faixa. Apresentamos na tabela 20 os resultados obtidos em número absoluto, bem como a diferença entre os 2 momentos de coleta. 
Tabela 20 - Comparação de frequência de citação de aspectos psicológicos entre os diferentes momentos, em números e aumentos em \%.

\begin{tabular}{lccc}
\hline Aspectos Psicológicos & $\begin{array}{c}\text { Pré e durante } \\
\text { intervenção }\end{array}$ & Pós-intervenção & $\begin{array}{c}\text { Diferença N- } \\
\text { Aumento (\%) }\end{array}$ \\
\hline P1 - até $4 \mathrm{~m}$ & $\mathbf{N}$ & $\mathbf{N}$ & N vezes a mais (\%) \\
$\mathrm{P} 2-$ até $8 \mathrm{~m}$ & 6 & 31 & $25(416,6)$ \\
$\mathrm{P} 3-$ até $12 \mathrm{~m}$ & 8 & 31 & $23(287,5)$ \\
$\mathrm{P} 4-$ até $18 \mathrm{~m}$ & Não coletado & 32 & - \\
\hline
\end{tabular}

Novamente houve um aumento de menção dos aspectos psicológicos após a formação IRDI. Encontramos 25 vezes mais citações (aumento de 416,6\%) quanto à faixa etária até 4 meses de idade do bebê, 23 em relação ao bebê de até 8 meses (aumento de 287,5\%) e 20 vezes mais menções (aumento de 222,2\%) com bebê de até 18 meses.

Os grandes aumentos quanto as frequências de citações de dados emocionais do bebê nos mostram efeitos positivos da formação IRDI. Mesmo depois de 3 meses da formação, nos deparamos com números crescentes com grande intensidade de citações emocionais, o que parece indicar que a formação contínua possibilitou aos participantes a interiorização de conteúdos referentes ao aspecto emocional do bebê.

\subsubsection{O que há nos aspectos psicológicos?}

De acordo com nosso interesse, focamos mais nas mudanças quanto ao aspecto psicológico e especificamos o que foi dito quanto aos dados emocionais do bebê. Portanto, ao aprofundarmos as análises dos aspectos psicológicos, classificamos os relatos em amplos e específicos. Aspectos amplos incluem citações sem muitas especificações como a interação do bebê com sua família e vice-versa; já os específicos, consideram indicadores e fundamentos do IRDI, bem como sentimentos dos bebês. Contabilizamos se os profissionais citaram apenas aspectos amplos, apenas específicos ou os 2 (ambos), como mostra tabela 21. Os números absolutos referem-se ao 
número de profissionais que citaram tal categoria e as percentagens foram calculadas entre todas as respostas obtidas em cada faixa etária.

Tabela 21 - Comparação de citações de aspectos psicológicos amplos e específicos entre os momentos antes e durante $\mathrm{X}$ após a intervenção, em número e percentagem.

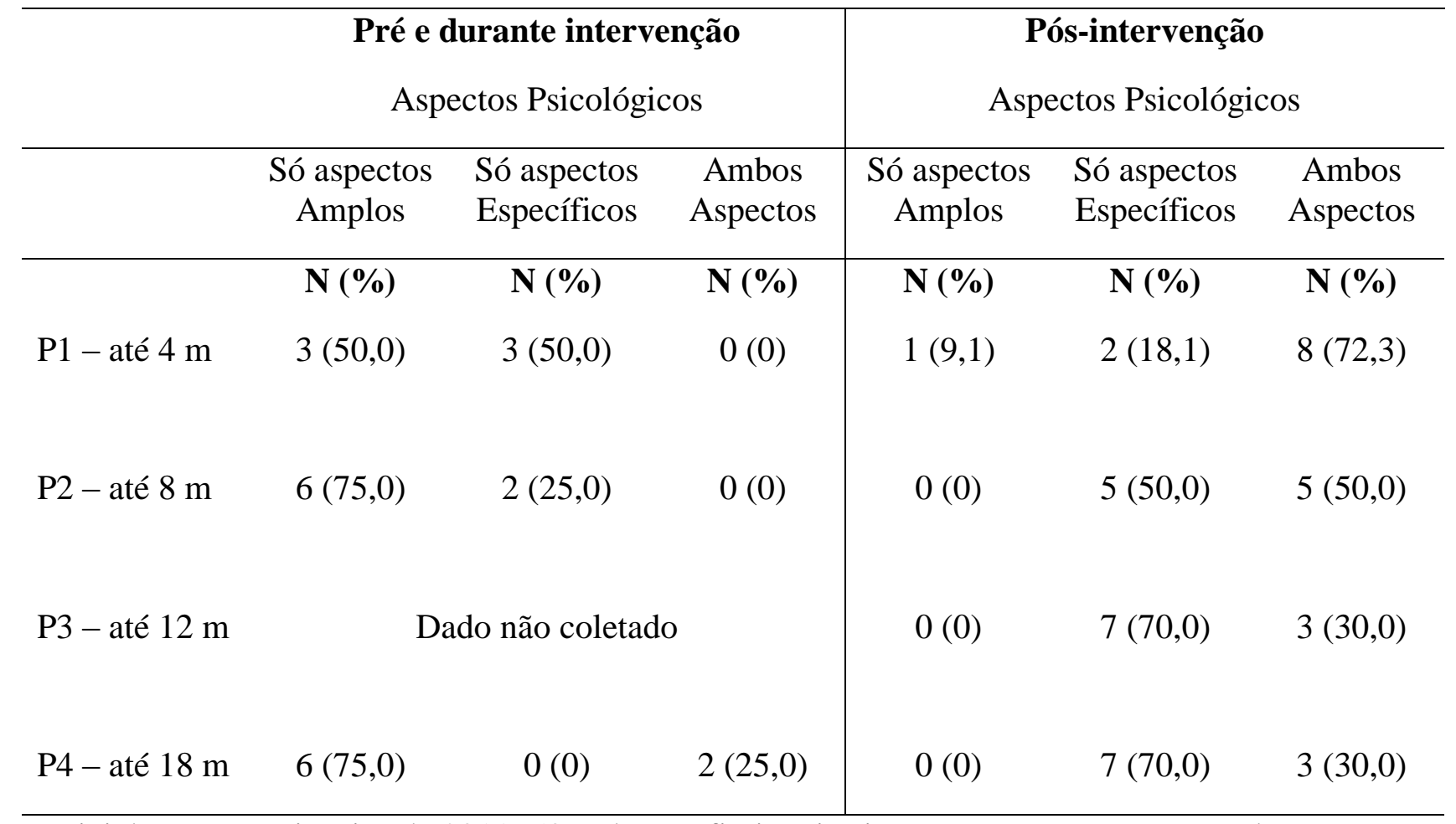

Inicialmente, em janeiro de 2011, 50\% dos profissionais citaram apenas aspectos amplos e outros $50 \%$ aspectos específicos. Em março, essa configuração passa a ser $75 \%$ e $25 \%$, respectivamente. Em dezembro, no fim da formação, tivemos $75 \%$ falando em aspectos amplos e $25 \%$ em ambos (amplos e específicos). Após a intervenção, os mesmos profissionais responderam basicamente só aspectos específicos ou ambos, tendo apenas $9,1 \%$ de aspectos amplos na primeira faixa etária, de até 4 meses. Ambos os aspectos foram citados de forma decrescente ao aumentar a idade do bebê, enquanto que os específicos foram crescendo. Assim, tivemos 72,3\% de ambos aspectos para até 4 meses, $50 \%$ até 8 meses e $30 \%$ para até 12 e até 18 meses e 18,1\% de aspectos específicos, $50 \%$ e $70 \%$, respectivamente.

A comparação de respostas obtidas ao longo do processo e após a formação nos evidencia que os profissionais não deixaram de mencionar os aspectos emocionais amplos - basicamente menções superficiais à interação mãe-bebê - mas ao término da formação passaram a relatar mais os 
aspectos específicos, considerando particularidades da interação entre a família e o bebê. Os aspectos específicos aumentaram 25\% na faixa de até 8 meses e $70 \%$ até 18 meses; ambos os aspectos foram citados em 72,3\% a mais após a formação referente a faixa até 4 meses, 50\% até 8 meses e 5\% até 18. Passou a haver uma maior menção de fundamentos e indicadores do IRDI, levando em conta sentimentos e sutilezas envolvidas na relação do bebê com sua família.

Prosseguimos analisando com que frequência esses aspectos apareceram e definimos um pouco mais os aspectos amplos, considerando-os em "apenas citação de interação mãe-bebê" e "como se dá a interação", já que percebemos uma mudança qualitativa nessas duas sub-categorias. Segue tabela com as frequências em que aspectos psicológicos são citados nessas sub-categorias.

Tabela 22 - Frequência de menção a aspectos psicológicos amplos antes, durante e após a formação, em números e aumentos em \%.

\begin{tabular}{|c|c|c|c|c|c|c|c|c|c|c|c|}
\hline \multirow{2}{*}{$\begin{array}{l}\text { Aspectos } \\
\text { Psicológicos } \\
\text { AMPLOS }\end{array}$} & \multicolumn{4}{|c|}{ Pré e durante intervenção } & \multicolumn{4}{|c|}{ Pós-intervenção } & \multicolumn{3}{|c|}{ Diferença N-Aumento (\%) } \\
\hline & $\begin{array}{l}\text { até } \\
4 \mathrm{~m}\end{array}$ & $\begin{array}{l}\text { até } \\
8 \mathrm{~m}\end{array}$ & $\begin{array}{c}\text { até } \\
12 \mathrm{~m}^{*}\end{array}$ & $\begin{array}{l}\text { até } \\
18 \mathrm{~m}\end{array}$ & $\begin{array}{l}\text { até } \\
4 \mathrm{~m}\end{array}$ & $\begin{array}{l}\text { até } \\
8 \mathrm{~m}\end{array}$ & $\begin{array}{l}\text { até } \\
12 \mathrm{~m}\end{array}$ & $\begin{array}{l}\text { até } \\
18 \mathrm{~m}\end{array}$ & $\begin{array}{l}\text { até } \\
4 \mathrm{~m}\end{array}$ & $\begin{array}{l}\text { até } \\
8 \mathrm{~m}\end{array}$ & $\begin{array}{l}\text { até } \\
18 \mathrm{~m}\end{array}$ \\
\hline & $\mathbf{N}$ & $\mathbf{N}$ & & $\mathbf{N}$ & $\mathbf{N}$ & $\mathbf{N}$ & $\mathbf{N}$ & $\mathbf{N}$ & $\mathbf{N}(\%)$ & $\mathbf{N}(\%)$ & $\mathbf{N}$ \\
\hline $\begin{array}{l}\text { Interação entre bebê e } \\
\text { família }\end{array}$ & 2 & 4 & $\begin{array}{l}\text { Dado } \\
\text { Não }\end{array}$ & 2 & 4 & 2 & 1 & 2 & $2(100)$ & -2 & $\mathbf{0}$ \\
\hline $\begin{array}{l}\text { Como é a interação } \\
\text { entre bebê e sua } \\
\text { família e vice-versa }\end{array}$ & 1 & 1 & Coletado & 3 & 6 & 2 & 2 & 2 & $5(400)$ & $1(100)$ & -1 \\
\hline TOTAL & 3 & 5 & & 5 & 10 & 4 & 3 & 4 & $7(233,3)$ & -1 & -1 \\
\hline
\end{tabular}

*Lembrando que não realizamos comparações quanto a esse momento da pergunta.

Considerando cada faixa etária (até 4, 8 e 18 meses) questionada antes e durante a formação encontramos a frequência 2, 4 e 2, respectivamente, de citações na sub-categoria interação entre bebê e família e 4, 2 e 2 citações nas mesmas faixas etárias, no entanto, após a formação. O que corresponde a um aumento de 2 citações, 100\% (até 4 meses,), diminuição -2 (até 8 meses) e ficaram equivalentes na faixa de até 18 meses. Esses dados aumentaram 5 vezes, 400\% (até 4 meses) e 1 vez, 100\% (até 8 meses) e diminuiu 1 (até 18 meses) na sub-categoria: como é a interação entre bebê e família. 
Quando analisamos as frequências de citações em cada sub-categoria observamos que em setembro de 2012, após 3 meses do término das monitorias, há grande menção de como está se dando a interação entre o bebê e a família, principalmente na primeira faixa etária que a frequência aumentou para 5. Após a formação, de forma geral, houve maior citação da subcategoria como é a interação entre bebê e família e diminuição na sub-categoria interação entre bebê e família. O que indica que as participantes não só intensificaram a menção a interação, como atribuíram uma mudança qualitativa nessa observação, estando mais interessadas na qualidade da interação, uma vez que querem saber como essa tem ocorrido, evidenciando uma mudança qualitativa na resposta.

Aprofundamos também as análises quanto os aspectos psicológicos específicos e esses também foram delimitados nas 3 sub-categorias: indicadores do IRDI, fundamentos do IRDI e sentimentos do bebê. Na tabela 23, apresentamos a frequência que elas aparecem em relação a cada faixa etária. As análises também foram realizadas por faixas, P1, P2, P3 e P4.

Tabela 23 - Frequência de menção a aspectos psicológicos específicos antes, durante e após a formação, em números e aumentos em \%.

\begin{tabular}{|c|c|c|c|c|c|c|c|c|c|c|c|}
\hline \multirow{3}{*}{$\begin{array}{c}\text { Aspectos } \\
\text { Psicológicos } \\
\text { ESPECÍFICOS }\end{array}$} & \multicolumn{4}{|c|}{ Pré e durante intervenção } & \multicolumn{4}{|c|}{ Pós-intervenção } & \multicolumn{3}{|c|}{ Diferença N-Aumento (\%) } \\
\hline & até & até & até & até & até & até & até & até & até & até & até \\
\hline & $4 \mathrm{~m}$ & $8 \mathrm{r}$ & $12 \mathrm{~m}^{*}$ & $18 \mathrm{~m}$ & $4 \mathrm{~m}$ & $8 \mathrm{~m}$ & $12 \mathrm{~m}$ & $18 \mathrm{~m}$ & $4 \mathrm{~m}$ & $8 \mathrm{~m}$ & $18 \mathrm{~m}$ \\
\hline & $\mathbf{N}$ & $\mathbf{N}$ & & $\mathbf{N}$ & $\mathbf{N}$ & $\mathbf{N}$ & $\mathbf{N}$ & $\mathbf{N}$ & $\mathbf{N}(\%)$ & $(\%)$ & $\mathbf{N}(\%)$ \\
\hline Indicadores do IRDI & 3 & 2 & Dado & 2 & 13 & 23 & 16 & 13 & $10(333,3)$ & $21(950)$ & $11(550)$ \\
\hline Fundamentos do IRDI & 0 & 1 & & 1 & 5 & 4 & 7 & 8 & $5(500)$ & $3(300)$ & $7(700)$ \\
\hline Sentimentos do bebê & 0 & 0 & Coletado & 1 & 2 & 0 & 6 & 6 & $2(200)$ & $\mathbf{0}$ & $5(500)$ \\
\hline TOTAL & 3 & 3 & & 4 & 20 & 27 & 29 & 27 & $17(566,6)$ & $24(800)$ & $23(575)$ \\
\hline
\end{tabular}

*Lembrando que não realizamos comparações quanto a esse momento da pergunta.

Ao verificarmos as comparações realizadas quanto aos aspectos psicológicos específicos é surpreendente o aumento nas frequências de citações após a intervenção em todas sub-categorias. Analisando separadamente, a sub-categoria indicadores do IRDI foi a que mais se destacou, os números subiram 10, 21 e 11 vezes, aumento de 333,3\%, 950\% e 550\% respectivamente, nas 
correspondentes faixas etárias 4, 8 e 18 meses. Na faixa até 12 meses não é possível fazer comparações, mas indicadores foram mencionados 16 vezes após a intervenção. De maneira geral, isso nos mostra que o conhecimento foi adquirido e mantido.

Quanto aos fundamentos do IRDI, as citações aumentaram 5, 3 e 7 (500\%, 300\% e 700\%) nas seguintes faixas etárias: 4, 8 e 18 meses após a intervenção e foram citadas 7 vezes na faixa de até 12 meses. Além de terem melhor precisão dos indicadores, as profissionais demonstram ter apreendido as bases fundamentais do IRDI com a formação.

Na sub-categoria sentimentos do bebê tivemos um aumento de 2 e 5 (equivalentes a 200\% e $500 \%$ ) citações para as faixas etárias até 4 e 18 meses, respectivamente, quando comparados os momentos antes e após a intervenção. Essa sub-categoria aparece mais fortemente nas últimas faixas etárias após a intervenção (até 12 meses foi mencionado 6 vezes e até 18 meses, também, sendo 5 vezes mais do que na ficha aplicada anteriormente ao $4^{\circ}$ encontro). Inicialmente tínhamos dúvidas se esse aumento devia-se ao próprio desenvolvimento do bebê ou a efeitos da formação. Acreditamos que maiores citações quanto à subjetividade do bebê mais velho também seja um efeito da formação; talvez fosse um conhecimento que já estivesse instalado nos serviços de saúde, advindo do senso comum, mas pôde ser aflorado com os incentivos ao aspecto emocional do bebê dados pela formação.

Como o número de indicadores foi elevado após a intervenção e essa sub-categoria foi a mais representativa, apresentamos no quadro 4 todos os indicadores do IRDI citados antes e durante intervenção e após a mesma nas diferentes perguntas realizadas P1, P2, P3 e P4, lembrando que cada uma delas se referia a uma faixa etária do bebê, bem como do protocolo IRDI, a saber: até 4 meses, até 8,12 e 18 respectivamente. 
Quadro 4- Frequências, em números, de indicadores do IRDI citados antes, durante e após a intervenção nas 4 perguntas realizadas (P1, P2, P3 e P4).

\begin{tabular}{|c|c|c|c|c|c|c|c|c|c|}
\hline \multirow[b]{2}{*}{ IRDI $l^{2}$ faixa -0 a 4 meses } & \multicolumn{2}{|c|}{ Pl-4m } & \multicolumn{2}{|c|}{ P2-8m } & \multicolumn{2}{|c|}{ P3-12m } & \multicolumn{2}{|c|}{$\mathrm{P} 4-18 \mathrm{~m}$} & \multirow{2}{*}{$\begin{array}{c}\mathrm{T} \\
\mathbf{0} \\
\mathrm{T} \\
\mathrm{AL}\end{array}$} \\
\hline & Pré & Pós & Pré & Pós & Pré & Pós & Pré & Pós & \\
\hline 1- Quando a criança chora ou gita, a mãe sabe o que ela guer & & 1 & 1 & 1 & & 2 & & 1 & 6 \\
\hline $\begin{array}{l}\text { 2- A mãe fala com a criança num estilo particulamente dirigido a ela } \\
\text { (manhês) }\end{array}$ & & 3 & & - & & - & & - & 3 \\
\hline 3-A criança reage ao manhês & & 4. & 1 & - & & - & & - & 5 \\
\hline 4-A mãe propõe algo à criança e aguarda sua reação & & - & & - & & - & & - & - \\
\hline 5- Há trocas de olhares entre a criança e a mãe & 3 & 4. & & 3 & & - & & - & 10 \\
\hline IRDI $2^{2}$ faixa -4 a 8 meses & & & & & & & & - & - \\
\hline 6-A criança começa a diferenciar o dia da noite & & - & & 1 & & - & & 2 & 3 \\
\hline $\begin{array}{l}\text { 7- A criança utiliza sinais diferentes para expressar suas diferentes } \\
\text { necessidades }\end{array}$ & & - & & - & & - & & - & - \\
\hline 8- A criança solicita amãe e faz umintervalo para aguardar sua resposta & & - & & - & D & - & & - & - \\
\hline 9- A mãe fala com a criança dirigindo-lhe pequenas frases & & - & & 3 & A & - & & - & 3 \\
\hline 10-A criança reage quando a mãe ou outra pessoa está se dirigindo a ela & & - & & 5 & $\mathrm{D}$ & - & & - & 5 \\
\hline 11- A criança procura ativamente o olhar da mãe & & - & & - & S & - & & - & - \\
\hline 12-A mãe dá suporte às iniciativas da criança sem poupar-lhe o esforço & & - & & - & & - & & - & - \\
\hline 13-A criança pede a ajuda de outra pessoa sem ficar passiva & & - & & - & & - & & - & - \\
\hline IRDI $3^{2}$ faixa -8 a 12 meses & & & & & $\ddot{\mathrm{A}}$ & & & & - \\
\hline $\begin{array}{l}\text { 14-A mãe percebe os pedidos da criança como uma forma de chamar sua } \\
\text { atenção }\end{array}$ & & - & & - & 0 & 1 & & - & 1 \\
\hline 15-Durante cuidados corporais, a criança brinca amorosamente com a mãe & & - & & - & $\mathrm{C}$ & 1 & & 2. & 3 \\
\hline 16- A criança demonstra gostar ou não de alguma coisa & & - & & - & $\mathrm{o}$ & 1 & & - & 1 \\
\hline 17-Mãe e criança compartilham uma linguagem particular & & - & & - & $\mathrm{L}$ & 1 & & - & 1 \\
\hline 18-A criança estranha pessoas desconhecidas para ela & & - & & 2 & $\mathrm{E}$ & 1 & 1 & 1 & 5 \\
\hline 19-A criança possui objetos prediletos & & - & & 1 & $\mathrm{~T}$ & - & & - & 1 \\
\hline 20 - A criança faz gracinhas & & - & & 2. & A & - & & 1. & 3 \\
\hline 21- A criança busca o olhar de aprovaç̃ão do adulto & & - & & 1 & $\mathrm{D}$ & - & & - & 1 \\
\hline 22-A criança aceita alimentação semi-sólida, sólida e yariada & & - & & 1. & 0 & 3 & & - & 4 \\
\hline $\begin{array}{l}\text { QDC 3A criança pega um objeto ou brinquedo da mão da pessoa que the } \\
\text { oferece }\end{array}$ & & - & & 1 & $\mathrm{~s}$ & 1 & & 1 & 3 \\
\hline QDC 6* A postura e os gestos da criança parecem adequados & & 1 & & - & & 1 & 1. & - & 3 \\
\hline IRDI $4^{2}$ faixa -12 a 18 meses & & & & & & & & & - \\
\hline 23-A mãe altema momentos de dedicação à criança comoutros interesses & & - & & - & & - & & - & - \\
\hline $\begin{array}{l}\text { 24- A criança suporta as breves ausências da mãe e reage às ausências } \\
\text { prolongadas }\end{array}$ & & - & & 1 & & 1 & & 1 & 3 \\
\hline $\begin{array}{l}\text { 25-Brinquedo é oferecido como altemativa do interesse da cça pelo corpo } \\
\text { matemo }\end{array}$ & & - & & - & & - & & - & - \\
\hline $\begin{array}{l}\text { 26-A mãejá não se sente mais obrigada a satisfazer tudo que a criança } \\
\text { pede }\end{array}$ & & - & & - & & - & & 1 & 1 \\
\hline 27- A criança olha com curiosidade para o que interessa à mãe & & - & & - & & - & & - & - \\
\hline 28-A criança gosta de brincar com objetos usados pela mãe e pelo pai & & - & & 1 & & - & & 1 & 2 \\
\hline $\begin{array}{l}29 \text { A mãe pede à criança que nomeie o que deseja e não se contenta só com } \\
\text { gestos }\end{array}$ & & - & & - & & - & & 1 & 1 \\
\hline 30-Os pais colocampequenas regras de comportamento para a criança & & - & & - & & 3 & & 1 & 4 \\
\hline 31 A criança diferencia objetos matemos, patemos e próprios & & & & - & & & & - & - \\
\hline TOTAL & 3 & 13 & 2 & 23 & - & 16 & 2 & 13 & 72 \\
\hline
\end{tabular}

*Os itens QDC 3 e 6 do Questionário do Desenvolvimento da Comunicação foram incluídos no protocolo IRDI, devido capacidade discriminativa estatisticamente significativa entre as patologias autismo, retardo mental e a normalidade. (Lerner,2011) 
De maneira geral, os indicadores são referidos dentro da faixa etária questionada, principalmente nas $\mathrm{P} 1, \mathrm{P} 3$ e P4. Na pergunta 1, quase todos os indicadores lembrados faziam mesmo referência à faixa etária questionada, ou seja, até 4 meses. Nas perguntas P3 e P4 concentram-se nos indicadores das faixas correspondentes, ou seja, até 12 e até 18 meses respectivamente. No entanto, são citados também indicadores de praticamente todas as outras faixas etárias, o que nos indica que foram indicadores marcantes para os participantes.

Analisando os indicadores que foram citados com maior frequência (4 vezes ou mais), considerando a somatória de todas as faixas temos $1,3,5,10,18,22$ e 30. Os indicadores 1,3 e 5 já foram relacionados em discussão acima quando falamos da surpresa dos participantes diante a subjetividade do bebê de até 4 meses. O IRDI 1 busca saber se a mãe supõe sujeito no bebê e se consegue se aproximar da realidade dele, lhe atribuindo sentido às experiências. O IRDI 3 verifica a resposta do bebê quanto ao manhês que se aproxima de uma preocupação marcante das profissionais, previamente à formação: as reações do bebê. O IRDI 5 verifica troca de olhares entre bebês e familiares e aparece novamente em discussões apresentadas adiante. IRDI 10 também é aprofundado em discussão adiante, busca-se verificar se a criança reage quando alguém se dirige a ela. IRDI 18, se os bebês estranham pessoas desconhecidas, apresenta uma preocupação parecida no senso comum, parece ser comum pessoas se preocuparem com isso, mesmo sem saber muito bem o porquê. Os IRDIs 22 e 30 abordam questões relacionadas à alimentação da criança e limites impostos pelos pais e também são aprofundados em discussões posteriores.

O QDC 3- A criança pega um objeto ou brinquedo da mão da pessoa que lhe oferece e o QDC 6A postura e os gestos da criança parecem adequados foram citados no total de 3 vezes cada e se assimilam bastante com preocupações das profissionais anteriores à formação, conforme pode ser visualizado no protocolo utilizado nos AEs (Anexo B).

No próximo item, exploraremos mais a menção aos indicadores feita nas perguntas P1, P2, P3 e P4, nos diferentes momentos que foram realizadas pré e pós-intervenção, seguida de discussão qualitativa. 


\subsubsection{Afinal, o que há de específico nos aspectos psicológicos?}

Com a finalidade de precisar um pouco mais o que há de específico em cada sub-categoria dos aspectos psicológicos, faremos novas descrições realizadas entre diferentes momentos de perguntas ao grupo intervenção, seguidas de discussão qualitativa. Ressaltamos que nesse momento exploramos os conceitos aprendidos, sendo priorizados os sentidos que a formação IRDI teve para os participantes, mais do que as frequências e dados quantificáveis.

Na sequência, analisamos as 3 sub-categorias dos aspectos psicológicos específicos (indicadores do IRDI, fundamentos do IRDI e sentimentos do bebê), conforme distribuídos na tabela 23 (página 104), quanto a P1, P2, P3 e P4, que se referem a faixas etárias do bebê diferentes de até 4 meses, até 8,12 e 18, respectivamente. Iniciamos as análises com a P1, verificando as respostas obtidas nos grupos pré e pós-intervenção quanto a essas 3 sub-categorias. $\mathrm{O}$ texto segue essa mesma ordem para as demais perguntas, considerando também a mesma sequência ao falar das sub-categorias. O quadro 4 (página 106) pode ajudar a visualizar os dados da sub-categoria indicadores do IRDI, frequentemente citada adiante.

Em indicadores do IRDI, na faixa etária até 4 meses encontramos anteriormente à formação, em janeiro de 2011, 3 respostas que se referem ao olhar (reconhece o olhar da mãe, olha para os olhos da mãe, acompanha o olhar da mãe). Preocupação essa que não deixa de ser anterior à formação IRDI, uma vez que no protocolo instituído já havia observação semelhante, no entanto, indica uma atenção voltada para uma complexidade relacional entre o bebê e sua família, talvez até mais do que a esperada para esse momento. Em setembro de 2012, nessa mesma subcategoria esse número aumentou para 5 e ainda foi lembrando em vários momentos durante as aplicações, como vimos nas monitorias.

Participantes se referiram a esse indicador durante monitorias e evidenciaram sua importância para o desenvolvimento emocional do bebê, além de parecerem ter sido fisgados pela forte relação subjetiva contida no ato do bebê olhar nos olhos do outro e mantê-lo. Angelina contou que ao se deparar com um bebê que não sustentava o olhar, mesmo não estando em serviço e nem num dispositivo de atendimento, o encaminhou imediatamente para unidade em que trabalha com $\mathrm{o}$ argumento de necessidade de melhor avaliação. 
$\mathrm{Na}$ ocasião, Angelina foi questionada pela pesquisadora sobre os motivos dessa conduta e a importância da troca de olhares, como resposta, tivemos: "porque o olhar é sinal de que o bebê está se abrindo para o mundo, que ele está no mundo e já saiu da barriga da mãe, e de que está se desenvolvendo bem." Ou seja, trata-se de um relato da atitude do bebê em estar no mundo e manter contato com os demais, há um conteúdo relacional que ocorre entre o bebê e os que estão a sua volta, que permite bom desenvolvimento emocional.

A participante Anita, ao ver a intensa troca de olhares entre uma mãe e sua bebê, mencionou que estavam namorando. Anita parece ter alcançado a essência da relação entre bebês e familiares, que não deixa de ser uma relação amorosa. O olhar e outras ações, assim como partes do corpo são libidinizados desde muito cedo através do contato que estabelecemos com os outros e apresentam grande função psíquica, que perduram por toda vida. (Freud, 1905)

Outras 5 menções também são marcantes quanto a essa faixa e não apareciam antes da intervenção. Trata-se da linguagem utilizada pelos familiares para se comunicar com o bebê e nessas, incluímos também indicadores que mencionam as respostas do bebê frente a esse linguajar particular. Detalhes da interação entre os pais e o bebê são descritos com precisão: “observo muito a mãe conversar com o bebê e ele responder; acorda, abre o olho e dá um sorriso para mamãe". O interessante é que a conversa aqui descrita não é necessariamente a fala, mas atitudes do bebê com seus pais, que envolvem ações executadas entre pausas: mãe conversa; bebê responde, acordando, abrindo os olhos e dando um sorriso, sendo essas alternâncias em se fazer presente e ausente essenciais para o desenvolvimento emocional da criança, como referido no capítulo IRDI.

Quanto aos fundamentos do IRDI, não há citação anteriormente à formação na faixa de até 4 meses, apenas após. 4 delas foram agrupadas por representar se a criança interpreta o que está acontecendo a sua volta e se de alguma forma responde a isso. São falas que se referem às expressões do bebê, buscam saber se o bebê diz de si para o outro e como o faz: 1- "Se a criança entende o que está ao redor dela"; 2- "Tem bebê que não tem reação nenhuma, tiramos a roupa e ele não chora. Ficamos assustadas, pois ele não estranha"; 3- "Se a criança transmite de alguma forma o vocabulário, o gemido é a fala dela, além do olhar, do choro"; 4- "Afetividade entre mãe e filho. Se a criança responde a troca de carinho entre mãe e bebê". 
Essas falas implicam um importante fundamento do protocolo, o estabelecimento da demanda. Esse eixo representa uma disponibilidade do bebê em estabelecer contato com os demais, sendo de extrema importância para seu desenvolvimento emocional que tal atitude seja interpretada como uma demanda ao outro.

Nessa faixa aparecem, após a formação, 2 menções quanto aos sentimentos do bebê: 1- "Se a criança é alegrinha ou não, a gente percebe o estado emocional, se a criança tá alegre ou triste"; 2- "Reações do bebê, se fica incomodado quando quer mamar e chora muito". São percepções quanto às oscilações de humor do bebê (alegre ou triste), suas reações e incômodos, considerando suas expressões e sentimentos, além do que está transmitindo para os que estão a sua volta.

Em março de 2011, na faixa etária de até 8 meses, aparecem 2 itens na sub-categoria indicadores do IRDI que já haviam sido introduzidos no primeiro encontro formativo (em janeiro), são eles: 1- "Bebê interage com a fala direcionada a ele" (IRDI 3); 2- "O choro é de dor, fome ou dengo" (IRDI 1). Em setembro de 2012, foram muitos indicadores citados nessa categoria (23) e também há uma variedade bastante grande deles, todas as faixas etárias foram citadas. Ao agruparmos, verificamos que a maioria ( 7 menções) diz respeito a falas direcionadas aos bebês e suas respostas quanto a isso, relacionadas aos indicadores 9- A mãe fala com a criança dirigindo-lhe pequenas frases e 10-A criança reage quando mãe se dirige a ela.

Dados de monitoria nos indicam que as vocalizações do bebê sempre fizeram parte do rol de preocupações das profissionais e, quando nos deparamos com frequentes citações dos indicadores acima (9 e 10), pensamos que provavelmente o que já era foco de atenção das profissionais parece ter sido reeditado com indicadores próximos a essas práticas pré-estabelecidas. Acreditamos que o sentido do uso desses indicadores pôde ser aprimorado pela formação, como também ocorrido com demais indicadores (IRDI 22, 29, 30), abordados adiante. Desde os primeiros acompanhamentos em AEs, também percebemos frequentes preocupações das participantes quanto ao bebê ser ativo ou não, que associamos ao IRDI 10. Diante dessas respostas, percebemos um refinamento qualitativo no discurso relacional do bebê, a atenção não é apenas se o bebê é ativo ou não, mas se diante do contato com o outro (IRDI 9, fala da mãe, que supõe um sujeito no bebê), verifica-se se ele responde a essa demanda e se também tende a estabelecê-la (IRDI 10). 
Ainda nessa sub-categoria e faixa etária o olhar continua ser marcante, com 4 menções quanto ao olhar do bebê, sendo uma delas diretamente relacionada ao indicador 11- A criança procura ativamente o olhar da mãe e outro ao IRDI 21 - A criança busca o olhar de aprovação do adulto. Segue descrição literal, para evidenciar o nível de apropriação do indicador: "Ele (o bebê) pede permissão a mãe. Ele não vai fazer nada sem olhar pra mãe, ele dá aquela olhada pra mãe. Ele tem essa ligação com ela, de dizer posso, não posso?”

Outros dois indicadores, também mais frequentes, referem-se à faixa posterior do IRDI, de até 12 meses: IRDI 20- A criança faz gracinhas para chamar a atenção, somando 3 citações e IRDI 18A criança estranha pessoa que não conhece, totalizando também 3 citações. IRDI 20 tem a ver com a disponibilidade do bebê em mais do que fazer contato com o outro, se fazer para o outro e estabelecer uma demanda. O IRDI 18 está estruturado no eixo da função paterna, mas nos parece ser uma preocupação anterior à formação, associada ao senso comum, como já dissemos. Outros 6 indicadores foram mencionados apenas uma vez: IRDI 1, 6, 19, 21, 22, 28 e QDC3, ainda que a maioria pertence à faixa referida, são indicadores de todas as faixas do protocolo.

Nessa mesma faixa etária de até 8 meses, na sub-categoria fundamentos do IRDI, apareceu em março uma única menção ("grita para chamar atenção"). Novamente estávamos diante de um bebê se fazendo para o outro. Em setembro, esse mesmo dado é ainda mais rico, com uma citação surpreendente por apresentar sutis detalhes que o mostram ainda mais dependente do outro, segue citação: “Aos 4 meses, o bebê quer se fazer ver, diz: 'oi, eu tô aqui', a mãe também quer apresentar o bebezinho, e dizer estamos aqui felizes ou não". Também há 2 citações em que o bebê tem atribuída a si vontade própria, diz-se de um bebê que escolhe se quer ir com o outro ou não e se já tem opinião própria. De alguma forma esses aspectos apareceram também em indicadores do IRDI, reforçando ainda mais suas apropriações pelas participantes. Há ainda uma última citação em fundamentos do IRDI com relação à preocupação de orientar as mães para a necessidade de que a fala seja direcionada ao bebê para que ele também possa se familiarizar com o mundo externo e objetos coletivos.

Na faixa de até 8 meses, não há citações quanto a sub-categoria sentimentos do bebê, nem antes e nem depois da formação. 
Quanto à faixa etária até 12 meses, não temos como estabelecer comparações, uma vez que não coletamos esses dados durante a intervenção, apenas após, em setembro de 2012. Mesmo assim, serão apresentados, articulados com dados de monitoria para evidenciar o processo de aprendizagem realizado, mais do que estabelecer comparações.

Na sub-categoria indicadores do IRDI dessa faixa (até 12 meses), verificamos que a maioria dos indicadores referidos são relacionados à faixa questionada e ainda há citações de itens da $1^{\mathrm{a}}$ e $4^{\mathrm{a}}$ faixa. Duas marcantes menções das participantes, citadas 3 vezes cada, referem-se a alimentação do bebê (IRDI 22) e imposição de limites à criança pelos pais (IRDI 30). São indicadores que retomam em alguma medida preocupações anteriores à formação e parecem ser associados à nova perspectiva atribuída a eles pela própria formação. Encontros de monitorias nos ajudam a exemplificar isso.

Percebemos grande atenção das profissionais quanto à alimentação do bebê, inclusive ao aleitamento materno logo nos seus primeiros meses de vida, como preza fortemente o discurso da saúde pública. No próprio protocolo de orientação dos AEs, instituído pelo município, conforme (Anexo B), encontramos algo a respeito, bem como questionamentos se a criança consegue levar sozinha o alimento a boca, parecendo avaliar suas competências neuropsicomotoras. Com o uso do IRDI, esses questionamentos passaram a ter um sentido diferente.

Anita, para citar um exemplo entre tantos, aplicava a terceira faixa do protocolo, quando a mãe disse que não dava alimentos inteiros para a criança de 11 meses (IRDI 22- A criança aceita alimentação semi-sólida, sólida e variada). Anita questionou a razão e a mãe contou que temia que a criança engasgasse. A profissional de saúde explicou que a criança teria capacidade para chupar o alimento e que só assim ele poderia fortalecer a mandíbula e estimular a dentição. Comentou que a criança já deveria comer arroz, feijão, legumes amassados, carnes desfiadas e que era importante experimentar coisas diferentes das que estava acostumada, para poder aprender a gostar delas.

Na aplicação da quarta faixa do IRDI, a criança veio em companhia da avó. Quando se perguntou se a criança comia bem, a avó contou que sim e que anteriormente, a mãe só dava comida batida, mas que recentemente introduziu alimentos amassados e em pequenos pedaços. A criança aceitou bem a nova alimentação, passando até mesmo a comer no mesmo prato que a mãe e a avó. 
A orientação feita por Anita contemplou elementos pessoais da mãe ao levá-la a explicitar seu medo de o filho engasgar, ao mesmo tempo em que mencionou a necessidade de que ele pudesse experimentar as comidas de que viesse a gostar, permitindo que a mãe se apropriasse da sua maneira do que foi orientado. O compartilhamento do mesmo prato da mãe e da avó, elemento cultural de ligação pessoal, familiar e íntima, reforça a natureza pessoal do contato com o menino, dando-lhe a oportunidade de estar em uma posição diversa da que tinha até então, mais de acordo com suas necessidades de desenvolvimento do momento.

Mencionamos acima também os limites impostos pelos pais, como uma possível reedição de sentido advinda da formação. Quanto a isso, foi referida a seguinte frase: "É a fase que começa a dizer não, por conta do perigo. Pais começam a dizer que aquilo é perigoso", que nos fez lembrar de acompanhamentos em monitoria em que orientações aos pais quanto prevenção de acidentes domésticos eram frequentemente abordados pelos profissionais. A referida "fase do não", representa o importantíssimo desfecho da constituição subjetiva, o eixo da função paterna, desmembrado em vários indicadores, principalmente os da $4^{\text {a }}$ faixa do protocolo, parece ter sido associada ao perigo inerente à fase em que a criança se apresenta mais autônoma. Assim como a imposição de limites necessários à criança e preocupações com a alimentação, associações entre conhecimento prévio ao IRDI e a formação parecem ter reeditado alguns indicadores, atribuindo maior sentido a eles, talvez daqueles mais próximos da realidade rotineira dos profissionais, como o caso do IRDI 29 que foi apresentado no item das monitorias, mais adiante.

Ainda na sub-categoria indicadores do IRDI quanto à faixa de até 12 meses, encontramos 2 menções aos pais que interpretam o que a criança quer, supondo sujeito no bebê (IRDI 1). Verificamos que esse indicador foi lembrado nas 4 perguntas realizadas (P1, P2, P3 e P4) por diferentes participantes, evidenciando ter sido fortemente assimilado. $\mathrm{O}$ fato de ter sido lembrado em todas as faixas questionadas intensifica a evidência de sua captura pelos participantes.

Outros 5 itens, referentes aos seguintes indicadores dessa faixa foram lembrados e, ainda que apenas uma vez, não são menos importantes: 1- "Se o cuidador percebe quando a criança quer chamar sua atenção" (IRDI 14), 2- "Se cuidador tem ações carinhosas durante os cuidados com o bebê (IRDI 15), 3- "Se a criança demonstra que não gostou da posição em que foi colocada (IRDI 16), 4- "Pela linguagem, através da fala e atitude a criança entende a mãe e a mãe entende a criança" (IRDI 17) e 5- "Se a criança chega perto de alguém que ela não conhece” (IRDI 18). 
Como toda estrutura do IRDI, são indicadores em que implicam a presença do outro e ao analisarmos essas citações percebemos que a criança está sempre sendo mencionada se relacionando com alguém: ela chama a atenção do outro, o outro percebe; ela recebe e dá carinho; mostra para o outro que não gostou de algo; se aproxima ou não de desconhecidos e mais, compartilha uma linguagem particular, que pode ser tanto a fala quanto gestos, com seus familiares.

Quanto aos fundamentos do IRDI, encontramos falas específicas dessa faixa etária (até 12 meses). Há menção a uma criança mais autônoma: 1- "Se quer sair pra passear e fazer as coisas sozinhas"; 2- "Vai demonstrar que quer alguma coisa"; 3- "Eles (as crianças) se colocam no que querem" e consequentemente ao eixo da função paterna, como momentos de restrições ou não por parte dos pais: 1- "Os pais estão perdidos, não sabem dizer não"; 2- (Nessa fase) "o relacionamento da mãe e do bebê é diferente, ele entende mais o não”.

Por fim, encontramos nessa sub-categoria também menção aos eixos estabelecimento da demanda e presença-ausência, seguem esses fundamentos implícitos na fala: "se é uma criança que se contenta com o que mãe dá ou chora sem parar”.

Ainda na faixa de até 12 meses, em sentimentos do bebê, nos deparamos com um bebê carregado de emoções: medroso, egoísta, faz pressão para que suas vontades sejam realizadas, rebelde, nervoso, agressivo e atencioso, como demonstradas nas frases a seguir: 1- "Medo de tirar roupa, porque acham que vão tomar vacina"; 2- "O bichinho já tá dizendo a mãe é minha, isso é meu, parte do egoísmo de não querer dividir"; 3- "Na parte física e psicológica bebê já faz pressão: ou você faz o que eu quero, ou... é difícil dizer o que a mãe deve fazer"; 4- "Tem bebê com um ano que é bem rebelde, de se jogar no chão, a mãe fica desesperada de chegar para a doutora e dizer que o bebê é muito nervoso"; 5- "Se criança é agressiva ou não"; 6- (Nessa fase) "o bebê é mais atencioso, observamos isso". Após a formação e a partir da faixa etária de até 12 meses, fala-se mais de um bebê provido de sentimentos, o que nos faz pensar que a subjetividade do bebê pôde ser mais bem explorada, após a intervenção em educação permanente.

Na sub-categoria indicadores do IRDI em dezembro de 2011, na faixa etária de até 18 meses, tivemos 2 indicadores citados referentes a faixa de até 12 meses, são eles: 1- "Se relaciona com desconhecidos" (IRDI 18) e 2- "Apresenta postura adequada" (QDC 6). Em setembro de 2012, 
foram 13 menções, sendo possível agrupá-los da seguinte maneira: 2 citações referem-se à rotina da criança quanto horário de sono (IRDI 6, até 8 meses) e outras 2 relacionadas ao ato da criança brincar com seus cuidadores (IRRD 15, até 12 meses). Foram citados ainda, isoladamente, os indicadores da $1^{\mathrm{a}}$ e $3^{\mathrm{a}}$ faixa etária: IRDI 1- Quando a criança chora ou grita, a mãe sabe o que ela quer, 18- A criança estranha pessoas desconhecidas para ela, 20- A criança faz gracinhas e QDC 3- A criança pega um objeto ou brinquedo da mão da pessoa que lhe oferece, já discutidos anteriormente.

5 indicadores, também citados isoladamente, pertencem à última faixa do protocolo: 1- "Se ao deixar seu filho com outra pessoa, a criança fica bem" (IRDI 24); 2- "Se as mães se sentem obrigadas a atender as demandas da criança. Mães que se sentem obrigadas a atender todas as solicitações da criança, quando estão em casa, fazem tudo que criança quer" (IRDI 26); 3- "Se a criança pega as coisas dos pais" (IRDI 28); 4- "Se a mãe ou cuidador pede para a criança falar o nome do objeto de desejo da mesma" (IRDI 29); 5- "Se os pais colocam regras para a criança ou não, se deixam fazer tudo que ela quer" (IRDI 30). São indicadores que buscam saber se a criança tolera a ausência dos pais, portanto, as separações; se os pais, por suas vezes, também se separam dos filhos ao imporem limites e regras e, por fim, se a criança se coloca na posição de sujeito, ao se interessar por objetos dos pais e querer usá-los. São indicadores que evocam características da função paterna e consequentemente o fechamento de um importante ciclo da constituição subjetiva.

Na faixa etária até 18 meses, em fundamentos do IRDI, antes da formação aparece uma citação relacionada à autonomia do bebê: 1- "Capacidade de solicitar o que precisa", que retorna com mais intensidade após a formação (6 citações): 1- "O bebê escolhe o que come, escolhe o que veste, arranca a touca"; 2- "Criança fica atenta quando toca o celular, já sabe atender”; 3“Criança tá mais esperta"; 4- "Criança já conhece as pessoas que convivem com ela"; 5- "Se a criança sabe o que tá fazendo, se sabe o que quer"; 6- "Criança está mais independente".

Nessa fase, fala-se de um bebê que tem uma relativa autonomia, que escolhe e sabe o quer, além de estar mais atento para os que estão a sua volta (objetos e pessoas). São fundamentos do IRDI que demonstram um bebê se fazendo cada vez mais sujeito. Percebemos uma mudança de discurso quanto aquele bebê de até 4 meses que estava mais voltado para o contato com os pais, agora encontramos um bebê mais independente, uma criança. Até mesmo essa palavra, passou a 
ser usada com maior frequência. Assim, as participantes evidenciaram que diferentes momentos do desenvolvimento do bebê requerem sutis mudanças de observação e atenção, parecendo ter sido possível acompanhar e transmitir as transformações do desenvolvimento do bebê com a formação proposta.

Os participantes ainda citaram mais 2 assuntos. Um, relacionando novamente essa faixa etária, a "fase do não": "é a fase do não, não pode". Outro se refere aos pais que conversam com seus filhos, nomeando o que está acontecendo na tentativa de deixá-los mais seguros: "Verifico se os pais explicam para a criança a importância do procedimento de enfermagem. Se falam, por exemplo, calma filho, é para o seu bem, a mamãe tá aqui”.

Na sub-categoria sentimentos do bebê, antes da formação, há uma menção à criança como mimada: se a criança é muito mimada e já começa de alguma forma manipular os pais. Fala-se de uma criança que quer que seja feita apenas a sua vontade e chega a controlar os pais para que isso ocorra, sendo eles também coniventes, por a mimarem. Após a formação, somaram 6 menções nessa sub-categoria: 1- "fica chatinho"; 2- "muito agitado"; 3- "nervoso, pois já sabe o que tá acontecendo"; 4- "se é calma ou tranquila"; 5- "se começa a fazer arte e 6- se faz birra". Aparece novamente uma criança que se expressa e manifesta suas vontades, além de ser apresentado um bebê provido de humor e emoções (nervoso, chato, calmo, birrento).

O fato de relatos quanto aos sentimentos do bebê quase não terem aparecido nos grupos prédurante intervenção e controle nos faz pensar que ocorreu um efeito da formação mais do que o próprio desenvolvimento da criança. Tínhamos a hipótese de que conforme o bebê fosse crescendo e ficando mais velho aparecessem mais aspectos subjetivos relacionados a ele, o que não se confirmou, tornando mais provável a ideia de que a formação "aflorou" esses conteúdos, que já deveriam permear o discurso das participantes. 


\subsection{Uma perspectiva qualitativa de apropriação do IRDI}

Diferentemente de dados obtidos com as questões fechadas das fichas de acompanhamento 1 e 2 , que nos deram resultados pouco expressivos, nesse item, mostraremos preciosos sentidos do uso do IRDI advindos da riqueza do contato que estabelecemos com as participantes nas monitorias ocorridas nos serviços de saúde. As cenas relatadas - ricas conversas e observações que evidenciam efeitos próprios desse contato em educação permanente - são seguidas imediatamente de discussão. Fizemos das monitorias um lugar de escuta das profissionais, onde foi possível fazer o trabalho de manutenção de demandas transferenciais, tendo como efeito melhoras nas percepções de aspectos emocionais dos bebês. Seguem, na tabela abaixo, números e percentagens de profissionais acompanhados em monitorias:

Tabela 24 - Número e percentagem de profissionais de saúde monitoradas por UBS no período de fevereiro/2011 a junho/2012

\begin{tabular}{|c|c|c|c|c|}
\hline $\begin{array}{c}\text { Unidades Básicas } \\
\text { de Saúde }\end{array}$ & Particip & fevereiro- & Partic & (março- \\
\hline & $\mathbf{N}$ & $\%$ & $\mathbf{N}$ & $\%$ \\
\hline Itatuba & 4 & 100 & 2 & 50 \\
\hline Vista Alegre & 4 & 100 & 2 & 50 \\
\hline Santa Emília & 4 & 100 & 1 & 25 \\
\hline Pinheirinho & 3 & 100 & 2 & 66,6 \\
\hline Centro & 2 & 100 & 1 & 50 \\
\hline Santa Tereza & 2 & 100 & 1 & 50 \\
\hline Santo Eduardo & 1 & 100 & 0 & 0 \\
\hline $\begin{array}{l}\text { Instituição } \\
\text { filantrópica* }\end{array}$ & 2 & 100 & 2 & 100 \\
\hline TOTAL & 20 & 100 & 9 & 45 \\
\hline
\end{tabular}


Como mostra a tabela 18, houve uma diminuição de profissionais para permanecendo na formação. Observamos que $9(45 \%)$ das 20 participantes escolheram continuar o curso e consequentemente finalizar a formação e a participação nas monitorias. As razões das desistências e não adesão a essa experiência de formação são diversas, e não pretendemos explicá-las em sua totalidade. Provavelmente, incluem-se nelas as limitações de nossa proposta, como a necessidade de acompanhar longitudinalmente as crianças e a existência de apenas 2 monitoras para atender as 14 unidades básicas de saúde.

Diante disto, buscamos detectar alguns fundamentos quanto à natureza da desistência e à natureza da permanência das profissionais. Também tentamos identificar quais eram os temores em usar o IRDI, ficamos atentos às ansiedades persecutórias que poderiam aparecer com relação ao bebê, a família, a instituição, ao encaminhamento, a detecção, e que provavelmente eram mobilizados pela própria estrutura do protocolo IRDI.

\subsubsection{Principais dificuldades encontradas}

Os atendimentos em enfermagem de pediatria (AE) realizados pelos profissionais é um atendimento carregado de tensões e é sentido em alguns momentos e por alguns profissionais como ameaçador. Bebês de baixo risco são vistos pela equipe de enfermagem nos primeiros 15 dias de vida e nos aos 2, 4, 8, 10 e 15 meses; quando há vaga, pediatras realizam consultas nos meses $1,2,3,6,12$ e 18 de idade da criança.

Ouvimos das participantes dessa pesquisa que muitas vezes se sentem impotentes, pois nem sempre sabem como acolher as queixas que surgem nos atendimentos, além de haver uma preferência das mães pelos atendimentos realizados por médicos. Relataram que se sentiriam mais seguras se ao menos houvesse um pediatra na unidade durante os AEs, pois assim poderiam recorrer ao mesmo quando necessário. Talvez estas sejam razões pelas quais nos deparamos ao início com um campo de trabalho em que não havia muito espaço para conversas, para histórias de vida, para as particularidades de cada família com seu bebê. Pudemos observar que é comum 
os profissionais se defenderem do contato mais íntimo com o bebê e sua família realizando cuidados mais técnicos, como medir e pesar.

Nesse sentido, Lucchese e Barros (2009) afirmam que apesar de o enfermeiro também ser ensinado a ouvir a queixa do paciente, ajudá-lo a tomar consciência do seu estado e apoiá-lo em suas atividades positivas, não é o que vem sendo encontrado na prática. As autoras realizaram um estudo sobre as competências do enfermeiro em Saúde Mental tanto na formação, quanto na prática e observaram uma competência burocrática, na qual o aluno de enfermagem é ensinado a seguir ordens médicas, o que configura um modelo de atuação também dessa natureza. Isto causa um impacto na disciplina de saúde mental, pois não encontram a mesma abordagem no ensino e na prática. A constatação de desempenho de atividades burocráticas e de submissão aos demais profissionais de saúde aponta para questionamentos sobre a identidade da enfermagem enquanto profissão.

Lembramos-nos de ocasiões em que nós pesquisadoras-psicólogas aplicamos o IRDI e iniciávamos perguntando para a mãe como era o bebê dela, enquanto os profissionais de enfermagem, na maioria das vezes, começavam pelo exame físico. Não que isso deveria ser diferente, afinal essa é a realidade deles, mas logo foi observado que havia uma dificuldade dos participantes em ouvir as duplas mãe-bebês e em poder agregar uma avaliação corporal (orgânica) com a avaliação das relações humanas. Nos primeiros meses de monitoria, também observamos algumas manifestações defensivas do uso do IRDI, principalmente nas primeiras faixas do protocolo.

A atitude defensiva considerada pode ser entendida à luz de ansiedades primitivas dos profissionais que podem ter sido mobilizadas pela situação de aplicação do IRDI. Melanie Klein (1991), em Notas sobre alguns mecanismos esquizóides (1946), afirma que desde o início da vida o ego experimenta ansiedades, usa mecanismos de defesa e forma relações de objeto (o registro psíquico que o bebê faz da pessoa com que se relaciona) que influenciam profundamente todos os aspectos do desenvolvimento. Inicialmente, nos estádios mais primitivos, o ego é amplamente desorganizado e apresenta uma tendência bastante lábil à integração das experiências sentidas como boas (prazerosas) e más (desprazerosas). 
A autora estruturou o funcionamento psíquico considerando a oscilação do ego entre duas posições: esquizo-paranoide e depressiva. Dependendo da capacidade do ego em suportar a angústia, predomina o funcionamento em uma determinada posição, sendo a partir desse enquadre que se configuram as defesas e as fantasias.

Souza (1995, p. 31), em estudo sobre inibição intelectual, refere-se ao funcionamento psíquico como determinante na possibilidade de uma criança aprender:

Não é suficiente ter capacidade intelectual para bem aprender. É necessário também que esta se acompanhe de uma estrutura de personalidade razoavelmente madura emocionalmente e, para tal, que tenha superado, com o auxílio de sua família, a etapa de seu desenvolvimento na qual predomina o processo primário (negação da realidade, onipotência, narcisismo, ausência de lógica, tempo e espaço), podendo assim utilizar-se do processo secundário de pensamento e de mecanismo de defesa mais evoluídos e adaptados à realidade.

Um funcionamento psíquico mais primitivo regido pela posição esquizo-paranoide pode indicar que a possibilidade de incorporação de um conhecimento se apresenta reduzida, já que o ego se encontra mais fragmentado e há um predomínio de mecanismos de defesas como os citados anteriormente pela autora.

Durante a formação do IRDI, nos deparamos com momentos em que mecanismos de defesas dessas naturezas se apresentavam muitas vezes como resistência ao conhecimento. Eles não são estanques, pelo contrário, apresentam uma transitoriedade que os fazem ir e vir, podendo surgir a qualquer momento. Quando fomos a campo (monitoria em serviço) para dar continuidade à formação iniciada nos encontros do IRDI (aula introdutória sobre cada indicador, de cada faixa) nos deparamos com dificuldades a serem rompidas perante um conhecimento novo e diferente.

Parece-nos muito importante relatar uma das primeiras dificuldades encontradas em formar profissionais de saúde para o uso dos indicadores. Trata-se de uma negação de que seu conteúdo fosse algo novo, muitas vezes ouvíamos que os itens avaliativos propostos pelo IRDI já se referiam a um conhecimento adquirido e a uma prática já realizada. Esse mecanismo de defesa representou inicialmente um obstáculo para aquisição de conhecimento que foi sendo quebrado aos poucos, como já apresentamos casos de indicadores que reeditaram a atuação das profissionais, efeito da formação. Parece não ter sido fácil ouvir de pesquisadores da Universidade de São Paulo que o conhecimento que se tem e a prática que se realiza não são 
plenos. Embora em alguns casos a primeira reação tenha sido de negação, aos poucos conseguimos trabalhar com esse material e avançar, como no caso relatado a seguir:

Em visita a uma unidade de saúde, após o primeiro encontro de formação do IRDI, fomos recebidas pelas auxiliares de enfermagem $\hat{A}_{\text {ngela }}{ }^{13}$ e Ariane, que relatavam a dificuldade em usar o protocolo nos atendimentos realizados, quando disseram que os itens do protocolo já eram vistos em seus atendimentos infantis. Ângela referia-se à ficha que orienta parte de suas condutas em AE e parece focar em modelos médicos avaliativos, como neurológicos, motores e biológicos.

Ângela parecia justificar o não uso do protocolo IRDI por ser parecido com algo já realizado. Questionamos, então, em que as fichas eram parecidas e apresentamos as duas: a ficha de atendimento em enfermagem já utilizada pela instituição: 1- Boa Sucção; 2- Movimenta braços e pernas ao mesmo tempo; 3- Chora frente ao desconforto; 4-Acorda ou assusta-se com barulho intenso e 5- Sustenta a cabeça. Os indicadores do IRDI 1- Quando a criança chora ou grita, a mãe sabe o que ela quer; 2- A mãe fala com a criança num estilo particularmente dirigido a ela (manhês); 3- A criança reage ao manhês; 4- A mãe propõe algo à criança e aguarda a sua reação e 5-Há trocas de olhares entre a criança e a mãe.

Ângela pensou, analisou e continuou dizendo que os dois protocolos eram muito parecidos. Mais adiante, perante nossa insistência, Ariane mencionou que via diferença entre os dois e essa diferença se baseava em quem deveriam observar. Ariane mencionou que a ficha que já usavam em seus atendimentos à criança atinha-se somente a ela; por sua vez, os itens do IRDI direcionam seu olhar para a interação entre a dupla mãe/criança.

O município de Embu investe bastante em cursos de capacitação sobre diversas áreas, principalmente em saúde da criança: mensalmente os profissionais são convidados a participar de diversos, mas nem sempre isso é bem aceito. Usos defensivos quanto aos cursos também apareceram e nos deparamos com limitações ainda mais complexas que dificultavam a participação na formação.

Alice, auxiliar de enfermagem, questionou quando seria nosso próximo encontro e orientou a informar a data para o departamento de enfermagem da Secretaria de Saúde, pois assim o

${ }^{13}$ Os nomes utilizados são fictícios, prezando o sigilo das participantes. 
comunicado viria de "cima", o que facilita sua ida ao encontro. Quando perguntamos o porquê, Alice contou que muitas vezes seus colegas de trabalho não gostam que ela se interesse por algum curso e que se ausente da unidade para participar do mesmo, pois, geralmente será compensada com uma folga por sua ida ao evento e deixará a equipe desfalcada, acarretando mais trabalho para profissionais que ficarão na instituição.

Alice mencionou ainda que, quando algum serviço ou atendimento na unidade de saúde diz respeito ao assunto abordado no curso, há um hábito de a equipe recorrer a alguém que tenha participado do mesmo, com a justificativa de que esse profissional está mais orientado para atender aquela demanda, uma vez que participou do curso e deve ter adquirido um conhecimento novo. Assim, o conhecimento tende a ficar isolado na pessoa que o adquiriu e não é irradiado ao serviço para ser institucionalizado.

Nesse caso, parece haver uma grande barreira para a novidade e para a mudança do funcionamento institucional, inclusive a que envolve a rotina da instituição. É como se Alice fosse "recompensada" com mais trabalho por ter adquirido um conhecimento novo e também por ter se ausentado para isso. Outros estudos (Leal, 2010), também relatam dificuldades de equipes de profissionais considerarem as visitas domiciliares, por exemplo, um avanço e não perda de tempo, como se o enquadre de trabalho precisasse ser mantido para ser visto como adequado.

Foram relatadas, ainda, dificuldades e certo embaraço em "convencer" as mães a participarem da aplicação do protocolo, o que nos faz pensar o quanto muitas vezes há uma ausência de sentido na prática de profissionais de saúde que os incapacitam de realizar algo novo, como a aplicação do IRDI.

A unidade de saúde passava por uma reforma e Ângela e Ariane passavam por um momento de indefinição de salas, sendo que mudavam frequentemente devido à pintura do local. As profissionais relataram a dificuldade em se organizar e justificaram a não aplicação do instrumento IRDI a partir desse cenário - já que as folhas do protocolo mudavam de local constantemente com o deslocamento dos móveis. De uma maneira simbólica, acreditamos que as profissionais falavam sobre uma mudança na própria prática que ocorreria com o IRDI e que as demandaria uma organização na rotina ainda não encontrada para a efetivação das aplicações do 
protocolo. No entanto, já percebemos que a dificuldade de instituir novas práticas é aos poucos contornada, mesmo que necessitando de muito trabalho contínuo e em longo prazo.

Notamos que uso do IRDI e a formação foram atravessados por complexas situações, tanto pessoais, como institucionais. Entre os entraves institucionais, destacam-se as limitações de espaço e tempo (já descritas em pesquisas anteriores, que também introduziram avaliações mentais em serviços de saúde ${ }^{14}$ ) para a aplicação do protocolo IRDI, as questões hierárquicas entre os diferentes cargos existentes nos serviços de saúde que determinam as funções de cada profissional e os confrontos entre diferentes perspectivas de atuação e de referenciais principalmente os conceituais que resultam uma dicotomia entre o orgânico e o psíquico.

Ana, enquanto organizava o armário de sua sala, falou claramente sobre a falta de tempo diante a quantidade de atendimentos e obrigações que devem realizar. A participante relatava a proposta municipal em atender as gestantes com seus respectivos maridos, para avaliação sanguínea e demais procedimentos: "não tem como dar conta, na teoria tudo é lindo, mas na prática... Eu até falei lá no curso: como vamos atender os pais também? São 16 gestantes agendadas numa manhã e agora vamos dobrar os atendimentos. Você vai conversar com uma gestante em 5 minutos? Não dá! É no mínimo vinte minutos. Além de outras coisas que precisamos fazer, você está de prova que até armário sobra pra gente arrumar.”

Quanto a influências das hierarquias que determinam as funções de cada profissional de saúde, por mais que tenhamos adaptado o IRDI à realidade dos profissionais de enfermagem reescrevendo alguns indicadores e a apostila explicativa de cada item, notamos que nem sempre os indicadores eram compreendidos pelas participantes, o que pode evidenciar uma grande distância de práticas. Durante as monitorias, nos perguntávamos em que medida o IRDI fazia sentido para as participantes. Avaliar o desenvolvimento emocional de bebês parecia ser uma realidade distante da atuação de todos profissionais de saúde, pois ainda se trata de um conhecimento específico, restrito ao profissional de saúde mental.

Acácia teve a experiência de realizar AE com uma psicóloga e durante o atendimento essa profissional pôde identificar uma mãe deprimida, o que fez Acácia relatar a importância da

\footnotetext{
${ }^{14}$ Pesquisa aponta a necessidade de tempo como limitação para o uso da escala M-CHAT por profissionais de saúde. Cf. Pinto-Martin J. A., Souders M. C., Giarelli E., e Levy S. E. (2005)
} 
presença de um psicólogo nos AEs, mesmo sabendo da distância que estava dessa realidade. Na ocasião, falamos que as diferentes formações possibilitam diferentes focos de atuação e intervenção. Acácia confirmou seu papel enquanto profissional de enfermagem, como realizar os procedimentos de puericultura que está habituada a fazer (verificar crescimento, vacinas, alimentação, desenvolvimento neuropsicomotor).

Em instituições de saúde é comum um discurso e uma prática hierárquica que caracteriza cada profissional: “Ah, é pra ver quem tá deprimida? Então, chama-se o psicólogo”. Isso evidencia o que cada profissional está autorizado a fazer, o que diz respeito a cada prática profissional e formativa, sabendo que entre as profissionais de enfermagem questões hierárquicas são ainda mais acirradas. Presenciamos em monitorias, medos de que o IRDI identificasse algo que justificasse encaminhamentos, já que esses últimos dizem respeito à conduta médica e diálogos entre saberes médicos e técnicos nem sempre são estreitos no campo de atuação da saúde. A formação IRDI teve justamente o desafio de diminuir a distância entre o papel de um e de outro, mas não podemos deixar de considerar a imensa tensão envolvida nisso.

Uma das expressões da confrontação entre diferentes referenciais é o uso que uma profissional chamou de "automático" do IRDI. Durante as aplicações do protocolo verificamos que as sutilezas do aspecto relacional do protocolo se perdem quando o item coincide com algo já instituído na prática dos profissionais de saúde. Por exemplo, em uma avaliação de um bebê de 7 meses é esperado, pelo protocolo institucional, que o profissional de enfermagem verifique se o bebê vocaliza.

O IRDI - 17 averigua se o bebê e a mãe compartilham uma linguagem particular, se se comunicam com elementos que foram construídos na intimidade dessa dupla e só fazem sentido dentro desse âmbito. Esse indicador avalia mais do que vocalizações, além de funções neurológicas e fonoaudiológicas, foca na relação que se estabelece com o outro. Mas, em monitoria, percebemos que para os profissionais de enfermagem nem sempre há diferenças entre o "bebê vocaliza" e o "bebê compartilha uma linguagem particular". Entendemos que isso ocorre, possivelmente, porque esses profissionais estão pouco familiarizados com uma perspectiva que verifica aspectos mais relacionais, mais sutis das relações humanas. Eles usam as referências que tem, e o desafio da formação foi transmitir algo diferente disso. O que inicialmente era 
considerado tudo a mesma coisa, aos poucos e com muito trabalho percebemos que pôde ser diferenciado, reatualizando as práticas exercidas pelas profissionais, como citamos no item anterior quanto aos indicadores 9, 10, 22, 29 e 30.

Outra expressão do automatismo no uso do IRDI foi a maneira de questionar os pais dos bebês acompanhados, a partir da leitura dos indicadores. Durante aplicação do IRDI, a participante Amanda, além de ler os indicadores, o que já dificulta sua compreensão, os lia sem interrupções, pausas e pontuações, tornando o texto e o indicador ainda mais inteligível para a mãe da criança com quem realizava a quarta faixa do protocolo. Diante de sua posição, a mãe não conseguia entender o que lhe era perguntado. Será que Amanda também sabia o que questionava?

Quanto a isso, Alana, auxiliar de enfermagem, realizava exames físicos em atendimento de puericultura ao bebê de maneira extremamente "automática" (como ela própria nomeou) ao ponto de não conseguir olhar para a criança. A proposta era que Alana realizasse o $\mathrm{AE}$ e aplicasse o IRDI no bebê. Alana conversou com o pai da criança sobre o período em que ele morou no exterior, enquanto media e pesava o bebê. Em nenhum momento a profissional se ateve ao bebê: se chorava, se olhava para a mãe, ou se havia incômodo com os procedimentos que lhe eram realizados. Alana ateve-se ao preenchimento do cabeçalho do protocolo IRDI e se interessou pela história de vida do pai, deixando de observar a criança nos momentos propícios. Quando estava prestes a dispensar a família, se questionou o que deveria responder quanto ao protocolo.

A cena nos indica que o automatismo institucional não permitiu que a profissional se abrisse para a relação do bebê com a família. Vimos que há pouco espaço para o bebê, para sua relação com a família, não há espaço para o IRDI. O automatismo e o tecnicismo não permitem que a rotina da instituição se volte para o singular, o subjetivo, o pessoal. Aplicar o protocolo e realizar o AE acabavam sendo tarefas distintas, sendo um desafio integrar o uso do IRDI na prática habitual das participantes. Deparamos-nos também com uma maneira de preencher o IRDI que pouco investigava no bebê e sua família o que se propunha: o protocolo era respondido sem muito perguntar e observar. Novamente estávamos diante do automatismo institucional.

Leal (2010) aponta que o trabalho pode ser produtor de sofrimento e desgaste quando burocratizado, fragmentado e centralizado, como vivenciaram os agentes comunitários de saúde participantes da pesquisa da autora, que criaram uma barreira ao ponto de não se sentirem mais 
íntegros no serviço que realizavam. Desafia-se estabelecer produções de trabalho que consigam integrar e abarcar a complexidade dos sujeitos.

As participantes falaram ainda das dificuldades em continuar a formação e aplicações sem o apoio institucional e das colegas de trabalho que deixaram de participar por alguma razão: "ficar sozinha é muito difícil, muito desanimador. Porque quando entrava aqui, uma criança da pesquisa, a Alana (colega de trabalho) já falava em pegar o IRDI para aplicar. Uma lembrava e incentiva a outra. Agora que ela (a Alana) está só de manhã, fica mais difícil.”

Constantemente ouvíamos relatos de solidão, seja porque começaram a formação em 4 participantes por UBS e finalizaram apenas com uma, seja porque ao aplicar o IRDI estariam deixando de realizar outra atividade da unidade, e sentiam-se pressionadas pelas demais, como relatado acima. Falava-se também da necessidade de formar a equipe inteira, na tentativa de que a "causa" fosse tomada pelo grupo todo e também a necessidade de encontros mais constantes com todos.

A importância de uma formação contínua se justifica pelo contato constante com o IRDI e principalmente com a atuação pouco habitual que ele requer, como mencionou Alice: os intervalos de 4 meses entre um encontro formativo e outro eram longos o suficiente para desanimá-la. Alice conta que se sentia mais motivada para dar continuidade à formação e aplicações quando voltava dos encontros com todos, fazendo-a pensar nas crianças que estava acompanhando. Questionamo-nos porque os acompanhamentos de monitorias entre os encontros formativos não teriam esse mesmo efeito. Isso parece indicar que a identificação com grupo fortalece bastante a atuação proposta.

A educação permanente requer uma articulação entre chefias, ministérios, saberes, entre outros. Percebemos a necessidade de se realizar uma intervenção com os apoios institucionais de diferentes ordens.

Encontramos dificuldades também em sustentar as aplicações do protocolo ao longo dos 18 meses de vida das crianças assistidas pela unidade de saúde. Claro que assistência longitudinal muitas vezes é inviabilizada, mas por que tamanha dificuldade se as crianças já deveriam ser seguidas até os 15 meses pelo protocolo institucional? A grande maioria das unidades de saúde 
participantes da formação encontrou uma maneira prática de concretizar as aplicações do IRDI no decorrer de 18 meses de vida das crianças acompanhadas: etiquetando prontuários, telefonando e agendando horários com os familiares dos bebês, reservando horários somente para a realização do IRDI na rotina da instituição foram as soluções mais comuns.

Leal (2010) refere-se a uma queixa de agentes comunitários em saúde quanto à ausência de um espaço físico para acolherem pacientes em sofrimento psíquico, interpretada pela autora como uma defesa a esse ato. Observamos atitudes parecidas com as profissionais formadas: quando relatavam dificuldades quanto ao enquadre, acreditamos que uma estrutura mínima seja necessária. No entanto, concordamos com Leal e diríamos que cuidar do outro em sofrimento emocional exige uma disponibilidade interna, que necessita ser construída e cuidada com muito trabalho, nem sempre possível aos profissionais de saúde.

Nem sempre o IRDI foi entendido ou aceito como um protocolo de saúde e acompanhamento do desenvolvimento. Pacientes, bem como profissionais mencionaram algumas vezes que o IRDI "não daria em nada", para justificar também suas dificuldades em dar continuidade às aplicações, por se tratar de um estudo longitudinal. Nem sempre foi possível avançar: às vezes e para alguns participantes o IRDI soou como um protocolo vago, ambivalente e sem concretude. A pergunta: “mas, no que isso vai dá?", sendo respondida: "vamos avaliando, vamos aplicando e aguardar para ver", num campo onde o tecnicismo é bastante arraigado, nem sempre fez sentido. Assim como também o medo que desse alguma coisa se tornava, às vezes, um opositor ao acompanhamento. Percebemos nesses encontros de monitoria que o sentimento de impotência diante das limitações humanas e também das advindas do próprio sistema de saúde muitas vezes as fazem resistir ao encontro com o paciente e ao cuidado mais pessoal.

A aplicação do IRDI exigia um grande esforço das participantes em integrar o IRDI aos moldes de atendimentos já realizados, por demandar uma postura destoante da prática habitual. Verificamos que uma complexidade de questões, inclusive psíquicas e institucionais, se misturam com os aspectos práticos. Em monitoria, uma participante contou que iniciou o curso, mas desistiu do mesmo e das aplicações, porque "não sabia de nada disso" (relação humana, subjetividade). Acácia, sua colega de trabalho e também participante da formação, se virou para a pesquisadora e comentou: "como você mesma viu, nem todo mundo tem perfil para isso. Tem que ter perfil. Vai falar o que pra ela?" 
Mesmo considerando todas as atribuições das profissionais de saúde e as limitações institucionais presentes em suas rotinas e demandas de atendimento, entendemos que a aquisição de conhecimento também é regida pelo mundo interno de cada participante e por mecanismos psíquicos que podem facilitar ou dificultar o "processo de aprendizagem", como bem mencionou Acácia.

Portanto, consideramos a influência de aspectos pessoais das participantes na formação IRDI e novamente esbarramos também numa configuração do sistema de saúde que não integra a subjetividade e a proximidade com o paciente: as instituições de saúde parecem apresentar uma "nuvem" defensiva que não permite aos profissionais se depararem com o sujeito, com a escuta, com a acolhida, com a singularidade, enfim, com características subjetivas.

$\mathrm{Na}$ literatura , encontramos relatos afirmando a relevância do estabelecimento do vínculo afetivo entre neonato e família para a saúde mental da criança: "é imprescindível a efetivação da ligação afetiva entre a criança e sua família, principalmente da criança com sua mãe, para que as bases de formação psicológica, do futuro adulto, sejam mantidas intactas” (Conz, Merighi e Jesus, 2009, p.850), o que justifica a realização de um trabalho que verifique a qualidade do vínculo afetivo, bem como suas consequências para o desenvolvimento infantil. No entanto, estudos realizados com profissionais de enfermagem apontam que eles não se sentem preparados para propiciar o vínculo entre a criança e a família, embora realizam esse trabalho e apresentam consciência de sua importância. Em consequência, as autoras fazem um apelo que esbarra na necessidade de reformas curriculares para consequente consideração do psiquismo na atuação profissional:

Urge a implementação de temas concernentes às relações humanas nos currículos do Curso de Graduação em Enfermagem, pois, atualmente, não se deve abordar somente Anatomia, Patologia, Fisiologia no ser humano, mas também priorizar o seu psíquico e o seu emocional diante de uma doença em qualquer parte e funcionalidade do seu corpo. (Conz, Merighi e Jesus, 2009, p.854)

Rocha (2005) realizou entrevistas com enfermeiros que atuam em equipes interdisciplinares de Centros de Atenção Psicossociais e constatou de maneira relevante a necessidade de obter conhecimento específico em saúde mental com a exigência de uma formação adequada e concluiu ainda que a formação em Enfermagem necessita de redirecionamentos e o estilo de aulas e as experiências que devem contemplar também precisam ser rediscutidos, dado que vem corroborar com a argumentação citada anteriormente. (Conz, Merighi \& Jesus, 2009). A autora 
esclarece também que o trabalho em saúde mental tem a especificação de o cuidado e o tratamento do paciente serem atravessados por sua singularidade e de toda a equipe de profissionais, o que implica um conhecimento sobre a pessoa; "os dados relevantes vão surgindo do contato cotidiano, da relação, da proximidade com o cliente e não do saber médico que determina um diagnóstico.” (Rocha, 2005 p.353)

A postura profissional do enfermeiro preconiza o cuidado ao paciente em suas diversas extensões, implicando a possibilidade de aproximação com o paciente em diferentes aspectos. No entanto, essa aproximação com o paciente vem se apresentando escassa no cotidiano dos enfermeiros, como também observamos no nosso campo de pesquisa. Mas por que tal dificuldade de aproximação? Porque envolve aspectos subjetivos e complexos que vão muito além da formação técnica. Observa-se também que a enfermagem não tem percebido e assumido o fato de estar muito distante do paciente que apresenta problemas emocionais (Rocha, 2005). Quanto a isso Silva, Furegato e Costa Júnior (2003, p.11) citam a pertinência em lembrar-se da "resistência que as pessoas têm em trabalhar com a doença mental, pelas dificuldades em lidar com suas próprias emoções e sentimentos."

Muitos autores referem-se à formação e à reforma curricular como estratégias para melhor a atuação e a orientação ao aspecto relacional de profissionais de enfermagem. Nossos resultados evidenciaram a extrema complexidade nessa mudança de perspectiva. Rocha (2005 p. 354) trata essa questão como um desafio para o ensino de Enfermagem e aponta que "certamente, nesse terreno as aulas teóricas são pouco úteis. Torna-se necessário encontrar caminhos para auxiliar o aluno a desenvolver inicialmente a intimidade consigo mesmo, a valorizar a subjetividade, para depois então se aproximar do outro." A ideia de que o percurso de ensino deve se voltar para o pessoal ficou bastante evidente na nossa experiência já que foram os participantes que estavam disponíveis a falar de si, de seus familiares, de suas infâncias, de seus filhos e netos e a nos mostrar suas maneiras particulares de acompanhar o desenvolvimento infantil que nos autorizaram a avançar e a trabalhar com eles.

Vale ressaltar que a formação ocorre também muito além de aulas teóricas: é no cotidiano, no trabalho em equipe e nas discussões com demais profissionais que o aprendizado é incorporado. Rocha (2005, p.354) relata que "o ensino se dá na interdisciplinaridade"; "na reunião de equipe 
aprendi mais do que no curso de especialização", como refere uma de suas entrevistadas. Não existe um objeto intermediário concreto entre o paciente e o enfermeiro psiquiátrico, "como uma bandeja, material para curativo ou para administração de um injetável. O objeto intermediário é a própria pessoa na relação profissional-paciente.” (Lucchese \& Barros, 2009, p.157)

\subsubsection{Evidências de apropriação do IRDI e engajamento na formação}

Em contrapartida ao uso defensivo do IRDI, tivemos outros bastante interessantes que evidenciaram a sua apropriação de maneira particular. As cenas relatadas nesse momento parecem evidenciar que contemplamos, em alguma medida, os objetivos dessa ação em educação permanente de considerar, aspectos psíquicos dos participantes, objetivando que a subjetividade de seus pacientes também pudesse ser considerada.

Adriana sempre utilizou o IRDI e sempre foi muita aberta a ele e usava os indicadores em avaliações de faixas etárias em que não havia nenhum protocolo institucional. Adriana completava os instrumentos IRDI e ficha da instituição, uma vez que esses instrumentos sugerem a observação de bebês em faixas etárias diferentes. Enquanto um menciona a idade de 8 meses e o outro não, Adriana supria essa lacuna de um dos instrumentos com os itens do outro.

Poderia ser questionável, no caso da Adriana, a maneira com que utilizava o IRDI, seguindo muitas vezes o protocolo de maneira pouco interativa com as famílias e os bebês avaliados posição mais defensiva que falávamos há pouco. Adriana é uma auxiliar de enfermagem acostumada a acompanhar bebês e orientar as mães. Sempre introduz nos atendimentos informações quanto à amamentação quando a criança é pequena ou quanto a quedas e acidentes domésticos quando a criança é maior e tem mais autonomia. A profissional também ensina as mães a realizarem massagens em seus bebês (Shantala).

Adriana realizava AE de pediatria e aplicava a quarta faixa do protocolo, quando perguntou para a mãe se ela estimulava seu filho de 13 meses a nomear os objetos (IRDI-29). A resposta foi negativa e a aplicação prosseguiu. No final do atendimento, a criança apontou para a caneta que 
estava na sua mão e gesticulou, expressando seu desejo por pegá-la. Adriana disse: "é a caneta que você quer? É? Então, fala c-a-n-e-t-a. É, c-a-n-e-t-a.” A auxiliar se voltou para mãe e disse: "viu, é assim que a gente faz quando a criança pede alguma coisa." Adriana finalizou orientando a mãe que seria importante incentivar seu filho dessa maneira para melhorar sua capacidade de se comunicar.

Em nenhum momento, durante a formação, instruímos as participantes a realiarem orientações. Consideramos os objetivos de sensibilizar as profissionais para a importância do desenvolvimento das funções psíquicas articulada com o desenvolvimento neuropsicomotor. Buscamos evidenciar que o vínculo entre pais e bebês é emocionalmente rico e deve ser vivido de forma a que os pais se engajem pessoalmente com o bebê, tomando-o também uma pessoa; tentamos instrumentalizar os profissionais para detectar sinais de sofrimento que se expressam nesse vínculo. A cena relatada acima com a participante mostra que a sensibilização levou-a a utilizar um sinal de possível sofrimento como um elemento de orientação para a mãe que ela acompanhava e o mais importante é que a natureza da comunicação ocorrida com a mãe não foi impessoal como costumava ocorrer com outras orientações que ela fazia em seu trabalho. Adriana ainda passou a se aproximar mais das famílias que acompanhava, deixando de apenas realizar perguntas, procedimentos e orientações pouco talvez sem sentido para as famílias.

Em encontros de monitoria, percebemos que Adriana sempre apresentou em sua conduta profissional a orientação aos pais e como vimos o uso do IRDI parece ter atribuído novo sentido para isso, nesse caso com o IRDI 29. No entanto, conforme abordamos no item acima sobre o que há de específico nos aspectos psicológicos, outros indicadores, como 9, 1022 e 30 puderam reorganizar as práticas dos participantes e isso não parece ser devido apenas aos indicadores em si, mas toda a forma como o protocolo IRDI e a formação foram estruturados.

Evidenciamos também que em alguns casos as próprias experiências pessoais asseguraram e levaram os profissionais a usar o protocolo, o que evidencia que o IRDI evoca particularidades, se presta a verificar conteúdos relacionais e, portanto, parece ser um convite aos aspectos subjetivos para quem também trabalha com ele.

Nas monitorias, observamos ainda a emergência de conteúdos pessoais dos participantes relacionados às suas experiências como filhos - e muitas vezes, como pais - e todo o embaraço 
envolvido nessas relações. Talvez seja possível pensarmos que essa forma de apropriação do IRDI aponta para implicações subjetivas que o próprio protocolo propõe ao solicitar que se observem as interações humanas.

Questionamos uma auxiliar de enfermagem sobre qual indicador elegeria importante para o desenvolvimento infantil e ela mencionou ser o item que verifica se a mãe fala com a criança, por analisar o relacionamento e a interação entre elas. Em seguida, a profissional contou espontaneamente sobre seus pais que não lhe diziam "eu te amo" e prosseguiu relatando sua difícil relação com a filha, uma vez que a mesma não aceitava o leite materno quando bebê e também não se sentia amada durante a adolescência, chegando a fugir de casa.

Diante dessa perspectiva, essa profissional defendia o uso do IRDI, reforçando que o mesmo observa as sutilezas e os aspectos relacionais entre pais e filhos e assim, ela acreditava que poderia beneficiar as famílias acompanhadas pelo protocolo. Percebemos que essa profissional nos falava do IRDI como uma maneira de auxiliar as pessoas nele envolvidas, inclusive ela mesma, uma vez que supostamente repararia seu pesar por não ter sido amparada em seus relacionamentos, ajudando os demais.

Como a formação IRDI frequentemente convidava os participantes a falar de experiências pessoais, em monitoria ouvimos várias histórias familiares das profissionais como mães, como Anete que disse: "eu me vejo com minha filha nisso aqui”, referindo-se ao IRDI. Ela relatou cenas de relacionamento íntimo com a filha, especificando as ações a partir do protocolo (troca de olhares, manhês) e prosseguiu comparando-a com o filho, que era um bebê hipoativo. Em seguida, Anete comentou que um bebê visto em AE lhe chamou bastante atenção por achá-lo muito "paradinho" e "pouco estimulado", dizendo sobre seu interesse em aplicar o IRDI nele e dessa vez o comparou com o próprio filho: "estimulei muito meu filho, esse bebê deve ser estimulado também".

O que chama atenção nessa cena é a sequência explícita de identificações proporcionadas pelo protocolo IRDI. Primeiramente, Anete se lembra de sua relação com a filha, depois com o filho, identificando-o com o paciente. O seu interesse em aplicar o IRDI num bebê paradinho tem um engajamento subjetivo já vivenciado com seu filho. Talvez fosse uma reedição dessa relação, como relatado em artigo, que as aplicações do IRDI podem auxiliar nos momentos em que a 
experiência pessoal da mãe é vivida com dificuldades, sendo a mãe, nesse caso, a própria participante (Lerner, Di Paolo, Campana, Morais, Tocchio \& Resegue, 2012). No entanto, o que fica evidente é que uma experiência pessoal a faz ter interesse no IRDI e nas relações afetivas estabelecidas entre o bebê e sua família.

Foram comuns as escolhas por aplicações do IRDI em bebês que por algum motivo chamassem a atenção das participantes, como relatou Anita: "são pessoas selecionadas que incluímos na pesquisa, não fazemos com todas, são só algumas", seja por uma proximidade parental (netos, sobrinhos, filhos de amigas), seja por alguma dificuldade específica da criança, como gemelares que tiveram intercorrências hospitalares, índice do apgar baixo, anoxia, entre outros, ou até mesmo por percepções subjetivas, como Arlete que escolheu acompanhar um bebê pela timidez de seu irmão mais velho.

Nesse caso, Arlete pôde verificar que a causa dos sentimentos de medo e timidez do menino não eram de responsabilidade materna como ela previa. Contou ter sido interessante observar essa família e se deparar com uma mãe muito "tranquila". Havia uma tentativa de correlacionar os aspectos subjetivos com históricos de saúde (intercorrências hospitalares, índice do apgar baixo, anoxia, internações, entre outros) e uma suposição de que pudessem acarretar em algo psíquico.

Os casos descritos acima podem ser articulados, em alguma medida, com o conceito kleiniano de reparação. Melanie Klein (1996) no texto Amor, Culpa e Reparação de 1937 apresenta um registro vivido por todos nós ao longo do nosso desenvolvimento psíquico que perdura por toda vida, que nos faz entender alguns mecanismos, de apropriação do IRDI, usados pelas profissionais. Klein afirma que temos o registro conflituoso de ódio à pessoa amada. $\mathrm{O}$ bebê ama e odeia a mãe, a ama por sentir-se satisfeito nos momentos que a deseja, ou que deseja algo que ela possa lhe dar, como o alimento, e a odeia por sentir-se frustrado quando não é atendido. Então, num primeiro momento da vida, nós enquanto bebês sentimos ódio frente à voracidade frustrada e culpa inconsciente por isso e consequentemente incertezas quanto nossas capacidades de amarmos e sermos amados.

Conforme o bebê se desenvolve, adquire novos interesses, passa a se relacionar com demais pessoas, para além de seu núcleo familiar e vivencia novas experiências e, portanto, passa a se sentir mais seguro da sua capacidade de amar e ser amado, mesmo considerando o ódio sentido. 
É nessa fase do desenvolvimento que conseguimos integrar ambos os sentimentos que eram muitos ambivalentes, até então.

No trecho a seguir, Klein (1996, p. 369) explicita essa importante fase do desenvolvimento psíquico que todos vivenciamos e nos permite avanços reparatórios de momentos anteriormente vividos com mais ansiedades e mecanismos de defesa, como a culpa inconsciente em odiar o objeto amado.

As novas companhias provam à criança que ela é capaz de amar e ser amada, que o amor e a bondade existem. Inconscientemente, isso é percebido como prova de que ela pode reparar os danos feitos aos outros na sua imaginação ou na realidade. Assim, as novas amizades ajudam a solucionar dificuldades emocionais anteriores, sem que a pessoa tenha uma noção precisa desses problemas iniciais nem da maneira como estão sendo solucionados. Através, desse processo, as tendências de fazer reparação ganham maior espaço, o sentimento de culpa é aliviado e se aumenta a confiança em si mesmo e nos outros.

Equivalentemente, acreditamos que vivências de reparação tenham sido mobilizadas com o uso do IRDI, sem que as participantes tenham noção precisa deles. Seja quando se deseja acompanhar uma criança porque é paradinha como era o filho da profissional, seja porque alguns participantes vivenciaram modificações na maneira de se relacionarem com seus próprios filhos: "passei a observar mais meus filhos e netos e os compreendo melhor. Me questiono porque ele está agindo de tal maneira e passei a me relacionar de maneira diferente com eles. Passei a conversar mais e brigar menos". Estão de acordo com esta perspectiva as percepções obtidas em estudo realizado por Leal (2010), que verificou a atuação de agentes comunitários de saúde em parceria com agentes de saúde mental. Foi observado que o próprio ACS se beneficiou com o aprimoramento do "olhar" desenvolvido pela nova maneira de atuação, tornando-o mais sensível também para voltar-se para o outro.

Ainda articuladas ao conceito de reparação de Melanie Klein, entendemos que as oscilações quanto ao uso do protocolo muitas vezes foram superadas tornando o sentimento de ambivalência quanto ao IRDI mais tolerado e integrado. Como o caso de Adriana, relatado acima, que passou a usá-lo de maneira menos defensiva.

No decorrer da formação, as cenas foram se reconfigurando e começaram a surgir diferentes demandas individuais para a pesquisadora, como solicitações de avaliações de crianças que não se encaixavam mais no acompanhamento IRDI, mas apresentavam alguma preocupação de 
ordem psicológica. Diante das dificuldades particulares das profissionais, foram realizados pedidos de conversas com pais de seus netos e demais pacientes assistidos. Após mais de um ano de trabalho, quando as monitorias se encerraram, Anita conta que seria muito bom se continuasse a ser acompanhada em monitoria durante os AEs.

Também foi sugerido que a monitora fizesse palestras sobre a importância do acompanhamento do desenvolvimento para os pais das crianças assistidas, como tentativa de alertá-los sobre a necessidade de presença nos AEs. Enfim, foram bastantes os pedidos das participantes, que expressavam o desejo de considerar a subjetividade do bebê em seus atendimentos e nas rotinas institucionais. Outros convites, mais pessoais, como a presença, como participante, em cursos do município e solicitações de novos encontros, também foram feitos pelas profissionais, parecendo ser uma tentativa de se manter em contato com o universo psíquico.

Ouvimos também relatos de maior segurança na atuação conquistada com o protocolo e formação. O IRDI passou a ser usado como parâmetro e a atribuir confiança à prática das participantes. Alzira relata a importância do estabelecimento de critérios avaliativos para sua prática. Conta que com o IRDI tem segurança que ausência de troca de olhares pode não ser um bom sinal para o desenvolvimento da criança e com a formação passou a ter segurança ao afirmar isso para os pais.

No mesmo ano em que encerramos a formação IRDI, iniciou-se no Embu uma formação para pediatras sobre detecção de autismo em bebês, coordenada por diferente grupo de profissionais. Ao saber disso, a auxiliar de enfermagem Anastásia apresentou o IRDI para a pediatra, colega de trabalho em sua unidade, dizendo que elas já tinham sido formadas para se ater ao bebê com sinais iniciais de psicopatologias e disseram já realizar esse trabalho com o IRDI. Anastásia fez questão também de explicar melhor o protocolo para a gerente da unidade, que já o conhecia, parecendo se assegurar do conhecimento que adquiriu e valorizá-lo.

Nossa participação no campo de pesquisa mostrou que as aplicações são influenciadas pelas dinâmicas institucionais. No entanto, muitas vezes tivemos participantes com uma extrema motivação pessoal, mesmo tendo agenda cheia e atividades excessivas, que realizaram um arranjo em suas atividades de trabalho para utilizar e aplicar o IRDI. Percebemos também que outros profissionais não o realizaram por considerar que já fazem muita coisa ou porque acham que são 
responsabilidades demais. Ágatha, auxiliar de enfermagem, nos contou que sua entrada no serviço público de saúde se deu de maneira um pouco inusitada. Ela havia realizado um curso à distância e sem que tivesse contato com a prática e com a assistência à saúde foi "inserida" numa UBS. Ágatha disse ter aprendido a atuar com a própria experiência e a princípio foi indicada para as funções que realiza sem saber como deveria prosseguir. Ela frequentava os encontros formativos e sabia que crianças eram acompanhadas pela unidade que trabalha, mas nunca havia aplicado o protocolo, inclusive relatou que deveria ter “toda uma técnica” para aplicá-lo.

Em 10 anos de atuação, Ágatha nunca havia realizado um AE, quando sua colega responsável por esse atendimento saiu de férias e a colocou no seu lugar. Ágatha realiza o AE pela primeira vez e aproveita para aplicar o IRDI, já que a monitora estava lá para acompanhá-la nas aplicações. Ao final do atendimento mencionou que faria com todas as crianças independente do dispositivo de atendimento e da formação IRDI, solicitando mais fichas de aplicação, inclusive de faixas anteriores. Interessante pensar que ela foi enganchada ao IRDI assim como em todas as outras práticas da unidade. Foi a partir da colega que se ausentou e da situação de ter crianças agendadas para o AE e para a aplicação IRDI que passou a se autorizar a ver bebês e usar o protocolo.

Ágatha também solicitou a opinião da monitora para melhorar a condução dos grupos de gestantes que realiza e iniciou contando como conduz o grupo: fala sobre a higienização e cicatrização do umbigo e técnicas de amamentação; ao término da conversa, mencionou que começaria com apresentações e nomes dos participantes, questionando se eles têm filhos e suas experiências enquanto pais, enfim, estimulando uma conversa em que surgissem dúvidas e fosse construída pelo próprio grupo: "porque pode ser que alguém já saiba amamentar e ensine para os demais, né?" Ágatha pôde ir de um caminho mais técnico para um que deu lugar a aspectos pessoais.

Ágatha ao atender um caso bastante complexo, em que a mãe da criança apresentava alguma deficiência mental e era auxiliada pela suposta sogra para cuidar de seu filho, que por sua vez aparentava dificuldades motoras e alguns ausentes no IRDI, teve a iniciativa, com o apoio da pesquisadora, de falar com a pediatra sobre o caso. Sua ação mobilizou toda a equipe que passou a fazer visitas domiciliares na casa desses pacientes na tentativa de entender melhor a dinâmica deles e ajudá-los. Realmente tratava-se de um caso difícil por apresentar diversas dimensões envolvidas, mais do que a avaliação da criança e provavelmente essa seria mesmo a conduta da 
instituição. No entanto, Ágatha disse que essa articulação foi devida à formação IRDI, ao fato de a pesquisadora estar lá acompanhando-a nos mínimos detalhes. O importante é que para ela, o IRDI e a companhia que teve em seus atendimentos fizeram-na sentir-se mais segura e competente em suas atitudes, desejando até mesmo que esses encontros continuassem, quando os finalizamos. Nesse caso, o valor atribuído à formação foi de uma maior articulação com a equipe, permitindo-a dialogar e contar mais com os colegas de trabalho. Essa experiência de um atendimento mais interdisciplinar pode ter tido sentido positivo, ao ponto de perdurar em sua atuação.

Após as primeiras tentativas em usar o IRDI nos AEs que realizava, Ariane conta ter dificuldade em "convencer" as mães a aceitar a participação. Entendemos que essa dificuldade provinha de seu próprio desconforto em aplicar o protocolo, uma vez que o realiza em conjunto com os procedimentos do AE, num grupo grande de pacientes. Diante do incentivo da pesquisadora em reservar um horário para as aplicações com um grupo restrito, Ariane conta que se surpreendeu com a frequente participação e presença das mães que aceitaram: "percebi que elas (as mães) se sentem acolhidas e ouvidas, a aplicação do IRDI é uma forma de dar atenção às mães e isso elas percebem, e por isso aderem ao acompanhamento”. Ariane percebe o efeito no vínculo estabelecido como as mães que atendeu ao ser sensível às suas particularidades e singularidades.

Fermino (2010), em dissertação de mestrado sobre a prática de trabalhadores em enfermagem (auxiliares e técnicos) conclui que, diante do sentimento de impotência do ato de cuidar e do esgotamento de recursos na saúde básica, esses profissionais utilizam-se de estratégias para solucionar problemas não abordados em consultas médicas, tratamentos medicamentosos e procedimentos. Uma das estratégias utilizadas pelos profissionais, citada pela autora, trata-se do uso de tecnologias leves, ou seja, o exercício do vínculo, do acolhimento, da escuta, da relação com o usuário do sistema de saúde pública. A autora aponta ainda que auxiliares e técnicos de enfermagem estão tomando para si o trabalho de conversar e acolher o usuário. Daí, afirma-se a importância em qualificar a escuta desses trabalhadores em educação permanente, que por sua vez, deveria ser introduzida em suas rotinas, para ampliação de intervenções e legimitização do uso dessa "tecnologia". No entanto, essas atuações nem sempre são valorizadas pelos próprios profissionais que, como mostra Fermino (2010), consideram conversas supérfluas, por se tratar de orientações pessoais. 
Como já vínhamos apontando, muitas angústias e defesas surgem nesse campo em que o corpo, o biológico e a doença deixam de ser os principais focos de atenção e "escudo" para a aproximação de ambas as partes. Deparamos-nos com o desafio de se considerar a subjetividade e a integralidade da atenção. Quando conseguimos experimentar novas formas de atuação e toleramos mais as angústias e tensões impostas entre diferentes práticas, avanços acontecem. Como o caso da própria Ariane que, além do que já exemplificamos acima, deixou de utilizar o IRDI como um protocolo a ser preenchido para nortear seu contato mais pessoal com os pacientes. Ariane passou a acolher e conversar mais com os pacientes que atendia e ainda nos contou outros avanços e rendimentos de sua nova prática: “antes eu só via o que estava no papel, se a criança sentava, sustentava a cabeça, essas coisas e se a mãe amamentava. Agora observo muito mais, ao ponto de perceber que tem algo entre aquela mãe e seu bebê. Nem sempre sei o que é, mas sei que tenho que ficar atentar, porque sei que alguma coisa tem.”

Ariane não sabe o que é, mas sabe que algo tem. As consideradas "tecnologias leves" pelo discurso da saúde e encontros subjetivos considerados pela psicologia são realmente poucos palpáveis. Fermino (2010) conclui na sua dissertação que são funções dos profissionais de enfermagem (auxiliares e técnicos) a assistência ao bem estar físico, assim como o conforto mental.

Em monitorias a uma Organização Social de Saúde (OSS) do município de São Paulo que também contribuiu como campo de pesquisa para esse estudo, mas não foi incluído nas análises estatísticas por não ter configurado o enquadre necessário, observamos que os vínculos estabelecidos entre enfermeiros e pacientes são bem mais estreitos e próximos, estabelecendo geralmente maior relação de confiança. Abigail, enfermeira, costumava acompanhar uma dupla mãe-bebê em consultas de enfermagem em pediatria que, na ocasião, tinha consulta com ela e com a pediatra da instituição, que encerra seu atendimento conversando com Abigail na frente da dupla. A médica havia diagnosticado uma hérnia umbilical na criança e a mãe volta-se para Abigail e a questiona se deveria colocar uma faixa na barriga da filha, para dificultá-la de mexer e prejudicar ainda mais o local. A mãe, de alguma forma, se sente mais próxima e à vontade para fazer uma pergunta, com conteúdo mais "caseiro" para a enfermeira, uma vez que a solução dada pela pediatra era esperar pela cirurgia. 
Parecem estar aí, no saber do usuário, as valorizações de cada profissional. É interessante observar também nessa instituição que as pacientes se vinculam mais às enfermeiras. As pacientes demonstram se sentir acolhidas e acostumadas a serem ouvidas por essas profissionais, ao ponto de acabar de sair de uma consulta médica e ir imediatamente mostrar pedidos de exames e receitas medicamentosas para as enfermeiras, que os olham, as escutavam com atenção e esclareciam suas dúvidas, orientando-as com relação aos próximos passos.

Nessa mesma ocasião, após o atendimento da pediatra, Abigail dirige-se para colega de trabalho e diz o seguinte: "a doutora já viu no exame físico as questões de desenvolvimento e agora a gente pode ver com a Andrea (monitora IRDI) as questões de desenvolvimento mesmo." Desenvolvimento MESMO. De que desenvolvimento estava falando? Afinal, o que é desenvolvimento? Quando as profissionais foram questionadas sobre isso, mencionaram: "é, os doutores fazem exame físico".

Toda a ação em educação permanente desenvolvida nessa pesquisa visou justamente ao estreitamento dessas concepções distintas entre exame físico e desenvolvimento mesmo. O desenvolvimento infantil deixa de ter sentido quando visto apenas do ponto de vista biológico; é necessário incluir o âmbito cultural que traz consigo o aspecto simbólico (Bernardino, 2007). A articulação entre biológico e simbólico é bastante complexa e o desenrolar do desenvolvimento infantil pode implicar riscos para a constituição psíquica e vice-versa.

Freud (2006), no texto Três Ensaios sobre a Sexualidade (1905), discute a influência de fatores hereditários (constitucionais) e relacionais (acidentais) nas constituições de psicopatologias e institui o conceito de "séries etiológicas", nomeado posteriormente de "séries complementares":

Não é fácil avaliar a eficácia dos fatores constitucionais e acidentais em sua relação recíproca. $\mathrm{Na}$ teoria, sempre se tende a superestimar os primeiros; a prática terapêutica destaca a importância dos últimos. Mas em nenhum caso se deve esquecer que existe entre ambos uma relação de cooperação, e não de exclusão. O fator constitucional tem de aguardar experiências que o ponham em vigor; o acidental precisa apoiar-se na constituição para ter efeito. Na maioria dos casos, pode-se imaginar o que se tem chamado de "série complementar", na qual as intensidades decrescentes de um fator são compensadas pelas intensidades crescentes de outro, mas não há razão alguma para negar a existência de casos extremos nos dois limites da série. (Freud, 1905, p. 226) [itálicos nossos] 
Embora o autor apresente a tensão entre os fatores orgânicos (maturacionais) e relacionais (subjetivos), como base das psicopatologias, ele não abandona nenhum dos fatores. Equivalentemente, afirmamos que o entrelaçamento do aparato orgânico do bebê e do vínculo afetivo entre ele e seus pais é determinante para a efetivação da constituição psíquica, assim como para o desenvolvimento geral da criança. Esse ponto articulatório entre o substrato orgânico e os aspectos relacionais e, consequentemente suas contribuições para desenvolvimento emocional e geral da criança, é descrito por Lerner (2011 p. 29):

A constituição subjetiva da criança e o engajamento das funções do desenvolvimento (como a sucção, a troca de olhares, a excreção, dentre outras) a seu serviço, além de dependerem da higidez do substrato neurológico em que se baseiam, devem orientar, em alguma medida, a especialização e a sofisticação deste substrato. Em outras palavras, a sofisticação do aparelho psíquico deve contribuir com a sofisticação do sistema nervoso, ao mesmo tempo em que dele depende.

Apesar das divergências apontadas acima, esse trabalho evidenciou que a intervenção em educação permanente permitiu que os profissionais de enfermagem fossem bastante suscetíveis a uma perspectiva integral de assistência à saúde infantil. $\mathrm{O}$ desafio é investir em articulações entre serviços de saúde, setores administrativos, conselhos de enfermagem, universidades e instância de políticas públicas (federal, estadual e municipal), para configurarem-se mais ações em educação permanente. Talvez, a primeira conquista seja a própria abertura do campo de estudo dessa pesquisa, por parte da Secretaria de Saúde de Embu das Artes em parceria com a Unifesp, e consequentemente seu interesse em incorporar o IRDI à rotina das unidades de saúde do município. 


\section{Considerações finais}


A educação permanente em saúde (EPS) é uma política de formação de trabalhadores da saúde que visa à articulação entre possibilidades de desenvolver a educação dos profissionais e ampliação da capacidade de atendimento dos serviços de saúde. Proposta pelo Ministério da Saúde e sustentada pelas diretrizes do SUS, a EPS evidencia articulações entre serviços de saúde e instituições formadoras.

Apesar de a educação permanente se propor a trabalhar interdisciplinarmente com estratégias de ensino contextualizadas e participativas e apontar para a transformação de práticas, há uma distância entre objetivos estabelecidos pelas diretrizes da EPS e a realidade (Freitas, 2011). Como no caso desse estudo, apesar de a Secretaria de Saúde do município onde ocorreu buscar implantar normatização para avaliação do desenvolvimento infantil no município, nem sempre foi possível trabalharmos a partir de demandas surgidas pelo próprio campo e estabelecermos as articulações necessárias entre gestores, secretarias e profissionais para a configuração de uma intervenção em EPS descrita por Peduzzi et al. (2004). Portanto, consideramos que instituímos, ao longo desse trabalho, ações incipientes em educação permanente.

Além de dificuldades encontradas para a configuração de uma intervenção em educação permanente, verificamos também lacunas na formação de profissionais de saúde em relação aos problemas de desenvolvimento infantil e nos serviços de saúde por nem sempre considerarem a subjetividade de pacientes e profissionais e as dificuldades que ela pode acarretar (Silva et al., 2004; Souza et al., 2000). A partir dessas circunstâncias, estabelecemos os objetivos de verificar como profissionais de saúde se apropriariam de um protocolo de saúde de desenvolvimento emocional infantil, e como o utilizariam em suas atuações com bebês.

Diante desses objetivos, estabelecemos uma formação com profissionais de enfermagem, utilizando um protocolo de saúde de desenvolvimento infantil, o IRDI - Indicadores Clínicos de Risco para o Desenvolvimento Infantil. A intervenção formativa foi sustentada na consideração da subjetividade de todos os envolvidos: profissionais, pacientes acompanhados, monitores, formadores e, assim, atingimos resultados significativos por diferentes ângulos. Inicialmente, apresentamos e discutimos resultados de perguntas fechadas que metodologicamente se mostraram limitadas para alcançar qualquer evidência de apropriação do IRDI, indicando que esse procedimento foi inadequado para a natureza da pergunta de pesquisa. 
Na sequência, mostramos com bastante saliência os efeitos positivos da formação com comparações estabelecidas, a partir de respostas quanto a atuações com bebês, entre o grupo formado e outros profissionais que não participaram da ação formativa, o grupo controle. Verificamos que os participantes da intervenção apresentaram significativamente maior consideração de aspectos psicológicos do desenvolvimento infantil em comparação com profissionais que não a realizaram. Comparações dos dados obtidos entre os momentos anterior e posterior à intervenção no grupo que a experimentou também mostraram avanços quanto à atualização de concepções de desenvolvimento emocional infantil. Ambos resultados evocam a conclusão de uma compreensão e assimilação dos conteúdos transmitidos pela formação IRDI.

Entendemos que apropriação de aspectos do desenvolvimento emocional infantil, através da formação e consequentemente do uso do IRDI, ocorreu em diferentes níveis. Com os resultados quantitativos mostramos que a aprendizagem, no nível cognitivo, é atingível a partir de ações formativas estruturadas para abordar questões subjetivas dos participantes e pacientes assistidos. Parece ter havido uma apropriação de conhecimento e esse foi o primeiro nível alcançado com a formação, mas não o único, embora muito importante. Os demais níveis foram evidenciados com estudos realizados somente com os profissionais formados. Ao continuarmos analisando respostas obtidas antes e após a intervenção em educação permanente, verificamos evidências de que a existência de subjetividade do bebê desde muito cedo surpreendeu os participantes. Acreditamos que esse foi um importante elo entre a aquisição de conhecimento e o engajamento na formação, que implicava justamente se abrir para o contato com o outro e com a própria subjetividade.

Com discussões qualitativas advindas dos acompanhamentos em monitoria em serviço mostramos que ações formativas estruturadas a partir da subjetividade têm capacidade de abrir para o âmbito psicológico e ressignificar práticas e relações dos profissionais estabelecidas entre seus familiares, pacientes, equipe e com o próprio trabalho.

Acreditamos que o acompanhamento contínuo dos profissionais para uma melhor apropriação dos conteúdos trabalhados e incorporação às práticas já realizadas seja um dos pontos chave da formação e do nível pessoal. O ponto principal da metodologia pedagógica não parece estar na condução de aulas, mas na relação entre os formadores e os participantes, bem como no acompanhamento da introdução de novas práticas que estão sendo propostas. 
Consideramos, assim, que a sensibilização dos profissionais formados é essencial para a transmissão do saber. Como o saber não é transmitido apenas mediante condições cognitivas, possibilitamos que a formação considerasse os aspectos psicológicos dos profissionais de enfermagem para que os mesmos pudessem se atentar para a subjetividade dos pacientes. Dessa maneira, interagimos com os profissionais, considerando o que eles pensavam sobre os assuntos abordados, construindo novos saberes a partir da experiência que eles estabeleceram conosco e com o IRDI, ao avaliarem o desenvolvimento infantil.

Apesar do apontamento de que é necessário um enquadre específico para se considerar uma prática educativa uma ação em educação permanente, identificamos que o trabalho voltado para o singular é forte o suficiente para reatualizar práticas em saúde quando essa prática é engajada com a subjetividade do profissional e consequentemente de pacientes, permitindo mudanças ao retornar-se para o profissional. Demonstramos que atingimos o nível subjetivo a partir de reatualizações de práticas exercidas com os bebês e famílias assistidas, das relações das participantes com familiares, principalmente filhos, netos e também com a equipe de trabalho, assim como na relação com o próprio trabalho.

Isso não desqualifica e nem desconsidera a necessidade do apoio articulatório com a gestão, pelo contrário: a sustentação institucional ao trabalho de educação permanente é outra interface do enquadre, dado que na claudicância ou ausência de um amparo institucional as condições se complicam. Acordos entre pesquisadores, profissionais de saúde, gerentes e superiores responsáveis pela secretaria de saúde e da educação fazem parte do nível institucional, e devem ser bem estabelecidos para melhor eficácia da formação. Assim, devemos contar com o respaldo institucional para que o trabalho seja articulado, sustentado por todas as partes e assim, mais efetivo.

Em suma, concluímos que atingimos uma apropriação de aspectos emocionais do desenvolvimento infantil a partir de 3 níveis: cognitivo, subjetivo e institucional, e suas articulações podem contemplar expectativas com ações em educação permanente, desde que com muito trabalho e investimento.

Por fim, ao longo das ações formativas nos demos conta que a formação de profissionais sob diferentes aspectos do desenvolvimento infantil demanda um enquadre específico para sua 
sustentação. Consideramos que a transmissão dos IRDI implica uma instrumentalização não reduzida à técnica, que viabilize o uso dos indicadores na prática que os profissionais já realizam, sem solapar as singularidades envolvidas no acompanhamento da relação bebê-cuidador.

Quanto à estrutura da formação, notamos que o acompanhamento dos profissionais in loco faz-se extremamente importante e necessário. A monitoria faz com que a formação seja contínua e possibilita que as dificuldades e as resistências sejam dissolvidas e trabalhadas, acarretando diferentes efeitos na própria formação e na aplicação do protocolo IRDI.

A formação contínua manteve os profissionais em contato permanente com os fundamentos do IRDI e facilitou as aplicações do protocolo, uma vez que este supõe a relação com questões subjetivas muitas vezes difíceis de serem suportadas. Ponderamos que para uma eficiência mínima dessa configuração de transmissão, faz-se necessário que os profissionais em formação sejam acompanhados. Além da necessidade de acompanhamento constante, notamos a necessidade de que encontros nos grandes grupos sejam mais frequentes, bem como a necessidade de formar a equipe toda.

É necessário, ainda, oferecer respaldo clínico para encaminhamentos e atendimentos por especialistas de crianças detectadas. Notamos a necessidade desses profissionais em assegurar-se que a evidência de sinais pelo protocolo não será em vão e que poderão utilizar o IRDI sem receio, já que a criança e sua família serão acompanhadas em tratamento específico. Daí a necessidade de parcerias com serviços de saúde que possam atender a demanda criada pelo uso do protocolo.

Percebemos, também, a necessidade de supervisionar todas as pessoas envolvidas na formação, inclusive o trabalho da monitora, uma vez que enfrenta resistências em seguir os atendimentos de bebês e angústias quanto à possibilidade de encontrar possíveis sinais de risco para o desenvolvimento infantil. Isso significa que devemos criar espaços de discussão para acompanhar atos e sentimentos frente ao campo de pesquisa em educação permanente. 


\section{Referências}


Andrade, L. O. M. De, \& Barreto, I. C. H. C. (2007) SUS passo a passo. História, regulamentação, políticas nacionais. São Paulo: Hucitec.

Bernardino, L. M. F. (2006). O que a psicanálise pode ensinar sobre a criança, sujeito em constituição. São Paulo: Escuta.

Bernardino, L. (2007). A contribuição da Psicanálise para a atuação no campo da Educação Especial. Estilos da Clínica, 7(22), 48-67.

Bernardino, L. M. F., Vaz, C., Quadros, M.,\& Vaz, S. (2008). Análise da relação de educadoras com bebês em um centro de educação infantil a partir do protocolo IRDI. In Lerner, R. \& Kupfer, M. C. M. Psicanálise com crianças: Cínica e pesquisa. São Paulo: FAPESP/Escuta.

Campana, N. (2012). Detecção precoce de risco para transtornos de espetro de autismo com Indicadores Clínicos de Risco para o Desenvolvimento Infantil. Relatório FAPESP de pesquisa de mestrado. Universidade de São Paulo: São Paulo

Campos, G. W. S. (2003) Paidéia e modelo de atenção: um ensaio sobre a reformulação do modo de produzir saúde. In: Campos, G. W. S. Saúde Paidéia. São Paulo: Hucitec; p. 103-21.

Carvalho, A. L., Silva, L. F., Grisi, S. J. F. E.,\& Escobar, A. M. U. (2008). Clinical indicators of child development in the capitals of nine Brazilian states: the influence of regional cultural factors. Clinics (São Paulo), 63, 51-58.

Ceccim, R. B. \& Feuerwerker, L. C. M. (2004) O Quadrilátero da Formação para a Área da Saúde: Ensino, Gestão, Atenção e Controle Social. Physis: Rev. Saúde Coletiva, Rio de Janeiro, 14(1), 41- 65.

Chiesa, A. M., Fracolli, L. A., \& Zoboli E. L. C. P. (Orgs.). (2009). Promoção de Saúde da Criança: a experiência do projeto Nossas Crianças: Janelas de Oportunidades. São Paulo: Escola de Enfermagem, Departamento de Enfermagem em Saúde Coletiva.

Conz, C. A., Merighi, M. A. B., \& Jesus, M. C. P. (2009, dezembro). Promoção de vínculo afetivo na Unidade de Terapia Intensiva Neonatal: um desafio para as enfermeiras. Revista esc. enfermagem. USP, 43(4), 849-855.

Di Paolo, A. F. (2010). Estudo exploratório dos indicadores clínicos de risco para o desenvolvimento infantil e da avaliação psicanalítica aos 3 anos para avaliar qualidade 
de vida e condição sintomática aos seis anos. Dissertação de Mestrado. Instituto de Psicologia da Universidade de São Paulo. São Paulo.

Fermino, T. Z. (2010) O processo de trabalho dos auxiliares e técnicos de enfermagem na atenção básica à saúde. Dissertação de Mestrado, Escola de Enfermagem, Universidade de São Paulo, Ribeirão Preto.

Freitas, Márcia Walter de. (2011) O modo de pensar a educação permanente em saúde em uma região da cidade de São Paulo. Dissertação da Faculdade de Saúde Pública da USP.

Freud, S. (2006). Três ensaios sobre a teoria da sexualidade (1905).In: Edição Standard Brasileira das Obras Completas de Sigmund Freud. Vol. VII. Rio de Janeiro: Imago

Geertz, C. (1989) Uma descrição densa: por uma teoria interpretativa da cultura. In: Geertz, C. A interpretação das culturas. Rio de Janeiro: LTC. (13-41).

Godinho T, Ristoff D, Fontes A, Xavier IM,\& Sampaio CEM (Orgs.) (2006). A trajetória da mulher na educação brasileira 1996-2003. Brasília (DF): INEP.

Jerusalinsky, A. (1999) Psicanálise e desenvolvimento infantil. Porto Alegre: Artes e Ofícios.

Jerusalinsky, A. (2008) Considerações acerca da Avaliação Psicanalítica de Crianças de Três Anos - AP3. In Lerner, R., \& Kupfer, M. C. M. (Orgs.) Psicanálise com crianças: clínica e pesquisa. São Paulo: Escuta.

Klein, M. (1991) Notas sobre alguns mecanismos esquizóides (1946). In Inveja e gratidão e outros trabalhos (1946-1963). Rio de Janeiro: Imago Ed,. p. 398

Klein, M. (1996) Amor, culpa e reparação (1937). In Amor, culpa e reparaçãoe outros trabalhos (1921-1945). Rio de Janeiro: Imago Ed,. p. 504

Kupfer, M. C., Bernardino, L. M. F., Jerusalinsky, N. A., Rocha, P. S. B., Lerner, R., \& Pesaro, M. E. (2008) A pesquisa IRDI: resultados finais. In Lerner, R. \& Kupfer, M. C. M. (Orgs.). Psicanálise com crianças: clínica e pesquisa. São Paulo: FAPESP/Escuta.

Kupfer, M. C. et al. (2009). Valor preditivo de indicadores clínicos de risco para o desenvolvimento infantil: um estudo a partir da teoria psicanalítica. Lat. Am. Journal of Fund. Psychopath. Online, 6(1), 48-68. 
Kupfer, M. C. M., Jerusalinsky, N. A., Bernardino, L. M. F., Wanderley, D. B., Rocha, P. S. B., Molina, S., et al. (2010). Predictive value of clinical risk indicators in child development: final results of a study based on psychoanalytic theory. Revista Latino americana de Psicopatologia Fundamental, 13, 31-52.

Kupfer, M. C. M. (2011). Metodologia IRDI: um instrumento de prevenção para o autismo. I Congresso Internacional sobre autismo. Anais do I Congresso Internacional sobre autismo. Curitiba: Associação de Psicanálise de Curitiba, 1, 15.

Laboratório de Epidemiologia e Estatística. (1995). São Paulo: Instituto Dante Pazzanese de Cardiologia. Recuperado em 01 de novembro de 2011, de http://www.lee.dante.br/pesquisa/kappa/index.html

Landis, J.R.,\& Koch, G.G. (1977).The measurement of observer agreement for categorical data. Biometrics. 33, 159-174.

Leal, B. M. M. L. (2010) Movimentos do cuidado em saúde mental na estratégia saúde da família. São Paulo. Dissertação de Mestrado Escola de Enfermagem da Universidade de São Paulo.

Lerner, R. (2008) Apresentação do livro Psicanálise com crianças: clínica e pesquisa. In Lerner, R., \& Kupfer, M. C. M. (Orgs.) (2008). Psicanálise com crianças: clínica e pesquisa. São Paulo: Escuta.

Lerner, R., \& Kupfer, M. C. M. (Orgs.) (2008). Psicanálise com crianças: clínica e pesquisa. São Paulo: Escuta.

Lerner, R. (2011). Indicadores Clínicos de Risco para o Desenvolvimento Infantil (IRDI): verificação da capacidade discriminativa entre autismo, retardo mental e normalidade. Tese de livre-docência, Instituto de Psicologia, Universidade de São Paulo, São Paulo.

Lerner, R., Di Paolo, A., Campana, N. Morais, A. S., Tocchio, A. B., \& Resegue, R. (2012, outubro) Uma contribuição da Psicanálise para a Saúde Coletiva: Protocolo de Indicadores Clínicos de Risco para o Desenvolvimento Infantil - Ganhador do Prêmio Comunidade e Cultura da Federação Psicanalítica da América Latina - São Paulo.

Lucchese, R., \& Barros, S. (2009, março). A constituição de competências na formação e na prática do enfermeiro em saúde mental. Rev. esc. enfermagem USP, 43(1), 152-160. 
Machado, F.P. (2012). Proposta de adaptação dos Indicadores Clínicos de Risco para o Desenvolvimento Infantil (IRDI) para questionário para pais e sua aplicabilidade no campo fonoaudiológico. Texto de qualificação de Tese de Doutorado. Pontifícia Universidade Católica de São Paulo: São Paulo.

Mariotto, R.M.M. (2007) Cuidar, educar e prevenir: as funções da creche no desenvolvimento e na subjetivação de bebês. Tese de Doutorado, Instituto de Psicologia, Universidade de São Paulo.

Minayo, M. C. S. (2010). O desafio do conhecimento: pesquisa qualitativa em saúde. São Paulo: Hucitec.

Ministério da Saúde do Brasil. (2002) Saúde da criança: acompanhamento do crescimento e desenvolvimento infantil/Ministério da Saúde. Secretaria de Políticas de Saúde. Departamento de Atenção Básica. Brasília: Ministério da Saúde.

Ministério da Saúde do Brasil (2007). Caderneta de saúde da criança. Recuperado em 17 de outubro de 2012 de http://bvsms.saude.gov.br/bvs/publicacoes/caderneta_saude_crianca_menina_7ed.pdf

Ministério da Saúde do Brasil (2011). Caderneta de saúde da criança. Recuperado em 17 de outubro de 2012 de http://189.28.128.100/nutricao/docs/geral/caderneta_saude_da_crianca.pdf

Peduzzi, M., Guerra, D. A., Braga, C. P., Lucena, F. S., \& Silva, J. A. M. (2009, julho) Atividades educativas de trabalhadores na atenção primária: concepções de educação permanente e de educação continuada em saúde presentes no cotidiano de Unidades Básicas de Saúde em São Paulo. Interface - Comunic., Saúde, Educ., 13(30),121-34.

Pesaro, M. E. (2010). Alcance e limites teórico-metodológicos da Pesquisa multicêntrica de indicadores clínicos de risco para o desenvolvimento infantil. Tese de Doutorado, Instituto de Psicologia, Universidade de São Paulo, São Paulo.

Pichon-Rivière, E. (1988) O processo grupal. São Paulo: Martins Fontes.

Pinto-Martin J. A., Souders M. C., Giarelli E., \& Levy S. E. (2005, junho). The role of nurses in screening for autistic spectrum disorder in pediatric primary care. Journal of Pediatric Nursing. 20(3), 163-9.

Reidy, J., \& Dancey, C. P. (2006) Estatística sem Matemática para Psicologia: Usando SPSS para Windows. Porto Alegre: Artmed, 608p. 
Rocha, R. M. (2005, setembro). O enfermeiro na equipe interdisciplinar do Centro de Atenção Psicossocial e as possibilidades de cuidar. Texto contexto - enfermagem. 14(3), 350357.

Scarcelli, I. R. \& Junqueira, V. (2011) O SUS como Desafio para a Formação em Psicologia. Psicologia: Ciência e Profissão, 31(2), 340-357.

Selltiz C., Wrightsman L. S., Cook A. W., \& Kidder L. H.(1981). Research Methods in Social Relations. New York: Holt, Rinehart \& Winston.

Silva, A. T. M. da et al. (2004, dezembro). Formação de Enfermeiros na perspectiva da Reforma Psiquiátrica. Revista brasileira de enfermagem, 57(6), 675-678.

Silva, M. C. F. da, Furegato, A. R. F., \& Costa Júnior, M. L. da (2003, fevereiro). Depressão: pontos de vista e conhecimento de enfermeiros da rede básica de saúde. Rev. Latino-Am. Enfermagem, 11(1), 7-13.

Souza, A. S. L. de. (1995) Pensando a Inibição Intelectual: perspectiva psicanalítica e proposta diagnóstica. São Paulo: Caso do Psicólogo. p. 122

Souza, M. C. B. M., Alencastre, M. B., \& Saeki, T. (2000, outubro). Enfermeiros assistenciais das instituições psiquiátricas de Ribeirão Preto: caracterização, formação e atuação. Rev. Latino-Am. Enfermagem, 8(5), 71-80.

Spink, M. J. \& Matta, G. C. (2007) A prática profissional Psi na Saúde Pública: configurações históricas e desafios contemporâneos. In Spink, M. J. P. (Org.) A psicologia em diálogo com o SUS - prática profissional e produção acadêmica. São Paulo: Casa do Psicólogo.

Tesser, C. D., Garcia, A. V., Vendruscolo, C.,\& Argenta, C. E. (2011) Estratégia saúde da família e análise da realidade social: subsídios para políticas de promoção da saúde $e$ educação permanente. Ciência \& Saúde Coletiva, 16(11), 4295-4306 
Apêndices 


\section{APÊNDICE A - APOSTILA PARA UTILIZAÇÃO DE INDICADORES CLÍNICOS DE RISCO PARA O DESENVOLVIMENTO INFANTIL - IRDI}

Os bebês nascem com capacidades que os levam a se relacionar com as pessoas que cuidam deles. A partir das interações que vivem com seus cuidadores, eles se desenvolvem transformando tais capacidades iniciais e também construindo novas.

Os indicadores são aplicados até dezoito meses do bebê e estão direcionados para as experiências de interação dele com seus cuidadores. Os itens do IRDI mostram sinais de bom desenvolvimento. Quando o bebê ou os cuidadores (pais, parentes ou outros) não apresentam algum item do IRDI, temos motivos para ficar atentos. Isso pode ser um sinal de que o desenvolvimento do bebê está em risco.

O IRDI e a apostila de capacitação, nos quais esse material se baseou foram construídos pelo Grupo Nacional da Pesquisa Multicêntrica ${ }^{1}$ com apoio do $\mathrm{CNPq}$, do Ministério da Saúde e da FAPESP.

\section{INSTRUÇÕES PARA APLICAÇÃO DO IRDI}

A) Com quem aplicar o IRDI:

Para usar o IRDI, você vai conversar com o a pessoa que cuida do bebê, mãe, pai, parente ou outro. É importante que o bebê e pelo menos um cuidador compareçam para você observar algumas situações que ocorrem entre os dois.

B) Como preencher as duas páginas do protocolo:

1. O protocolo tem duas páginas: uma é a folha de rosto e outra é a ficha de aplicação. A ficha de aplicação será recolhida periodicamente e substituída por outra em branco a ser preenchida no atendimento seguinte. A folha de rosto permanecerá no prontuário da criança, na unidade de atendimento.

2. Preencha a folha de rosto com todos os dados na primeira aplicação de cada bebê. Anote também a data do encontro em que foi feita a aplicação. Nas outras vezes em que aplicar o IRDI no mesmo bebê, anote nesta folha apenas a data de cada nova aplicação.

3. Antes do atendimento, leia os itens do IRDI referentes à faixa etária do bebê que estão na ficha de aplicação. Anote no cabeçalho as informações pedidas. As anotações nesta ficha devem ser realizadas durante ou logo após o encontro.

C) Durante a aplicação:

1. Quando necessário, podem ser utilizados brinquedos ou objetos disponíveis ou trazidos pelo cuidador: caneta, folha, fita métrica, chaves, paninho da criança.

\footnotetext{
${ }^{1}$ Grupo de especialistasconvidados pela Profa.Dra. Maria CristinaMachado Kupfer, do IPUSP, para construir os indicadores e conduzir a pesquisa nos múltiplos centros de saúde: Profa. Dra. Leda M. Fischer Bernardino, da PUC-Curitiba; Paula Rocha e Elizabeth Cavalcante, do CPPL - Recife; Domingos Paulo Infante, Lina G. Martins de Oliveira e M. Cecília Casagrande, de São Paulo; Daniele Wanderley, de Salvador; Lea M. Sales, da Universidade Federal do Pará; Profa. Regina M. R. Stellin, da UNIFOR - Fortaleza; Flávia Dutra, de Brasília; Dr. Octavio Souza, do Rio de Janeiro; Silvia Molina, de Porto Alegre; sob coordenação técnica de M. Eugênia Pesaro, coordenação científica do Dr. Alfredo Jerusalinsky e coordenação nacional da Profa. Dra. Maria Cristina M. Kupfer.
} 
2. Em alguns itens, você deverá observar mais o cuidador do que o bebê e em outros, o contrário. Existem itens em que você deverá observar os dois ao mesmo tempo. Quando for necessário perguntar algo, não comece perguntando diretamente, mas solicitando que o cuidador fale sobre as situações envolvendo o assunto do item. Isso vai ficar claro nos exemplos específicos de alguns itens.

3. A cada vez que usar o IRDI, você deverá preencher todo cabeçalho da ficha e escrever o resultado da aplicação da seguinte maneira: se você tiver observado aquilo que o item descreve, escreva $\mathbf{P}$, de "Presente". Se a situação do encontro não permitir que você saiba se o que o item descreve acontece ou não, escreva $\mathbf{N V}$, de "Não verificado" (por exemplo, quem trouxe o bebê não sabe se ele dorme de noite e fica acordado de dia, item 6). Se você tiver observado que aquilo que o item descreve não ocorre, escreva A, de "Ausente". Se tiver escrito A ou NV, anote um breve comentário.

4. O espaço livre na coluna "Observações" ao lado de cada indicador pode ser utilizado para anotação do que o pesquisador considera importante. O preenchimento da coluna não é obrigatório, a menos que um indicador tenha sido considerado não verificado ou ausente.

\section{Exemplo:}

\begin{tabular}{|c|c|c|}
\hline Indicadores de 0 a 3 meses e 29 dias: & $\begin{array}{l}\text { Anotar } \mathrm{P}, \mathrm{A}, \text { ou NV } \\
\text { para cada item }\end{array}$ & Observações: \\
\hline $\begin{array}{l}\text { 1- Quando a criança chora ou grita, } \\
\text { a mãe sabe o que ela quer. }\end{array}$ & $\mathbf{P}$ & \\
\hline $\begin{array}{l}\text { 2- A mãe fala com a criança num } \\
\text { estilo particularmente dirigido a } \\
\text { ela (mamanhês). }\end{array}$ & $\mathbf{A}$ & $\begin{array}{l}\text { A mãe nunca fala com o } \\
\text { bebê de maneira } \\
\text { especialmente carinhosa. }\end{array}$ \\
\hline 3- A criança reage ao mamanhês. & $\mathbf{P}$ & \\
\hline $\begin{array}{l}\text { 4- A mãe propõe algo à criança e } \\
\text { aguarda a sua reação. }\end{array}$ & $\mathbf{P}$ & \\
\hline $\begin{array}{l}\text { 5- Há trocas de olhares entre a } \\
\text { criança e a mãe. }\end{array}$ & $\mathbf{A}$ & $\begin{array}{l}\text { O bebê não olhou pra a } \\
\text { mãe em nenhum } \\
\text { momento. }\end{array}$ \\
\hline
\end{tabular}

Legenda: $\mathrm{P}=$ Presente $; \mathrm{A}=$ Ausente $; \mathrm{NV}=$ Não verificado

D) Itens a serem observados:

\section{Período: de 0 a 3 meses e 29 dias}

1 - Item 1: Quando o bebê chora ou grita, a mãe sabe o que ele quer. Quando o bebê chora, faz balbucios ou outros sons, pode acontecer de a mãe não fazer nada (então você pergunta se ela sempre fica quieta daquela maneira quando o bebê faz aquilo. Se a mãe disser que sempre fica quieta, você marca AUSENTE) ou a mãe pode responder ao bebê de algumas formas: "O que foi? O que você quer? Você está com fome? A fralda tá machucando? Tá de cocô?" Com isso, a mãe imagina o que o bebê está precisando e pode oferecer o seio, a chupeta, o paninho, ou até ajeitar o bebê no colo de maneira diferente, etc. Nesse caso, você marca PRESENTE. 
2- Item 2:A mãe fala com o bebê num estilo particularmente dirigido a ele (mamanhês).

Geralmente falamos com os bebês de um jeito diferente de como falamos com os adultos. As mães, principalmente, usam um tom de voz infantil, o "mamanhês". Usam frases curtas: "Ahhh cê tava nanando?", repetem as sílabas, como: papá, nenê, mamá, babá, naná, etc... e usam palavras no diminutivo com entonação exagerada: "Que bonitinho o nenezinho da mamãe!" Você deve verificar se a mãe fala dessa maneira com o bebê. Se isso ocorrer, você marca PRESENTE. Para estimular esse tipo de conversa, você também pode falar dessa forma com o bebê, para diminuir o clima de formalidade que às vezes tem na consulta. Se achar melhor, pergunte como a mãe conversa com o bebê e peça para que ela mostre.

3 - Item 3: O bebê reage ao mamanhês.

A cada vez que a mãe falar com o bebê em "mamanhês", veja a reação dele e marque PRESENTE se ela existir. Preste atenção se o bebê estava olhando para outro lugar e passou a olhar a mãe, observe os movimentos corporais, sorrisos, tentativa de resposta e sons do bebê quando a mãe falar com ele dessa forma. Se o bebê não reagir ao "mamanhês", marque AUSENTE.

\section{4 - Item 4:A mãe propõe algo ao bebê e aguarda a sua reação.}

Verifique se, após atender a alguma solicitação do bebê, a mãe "dá um tempo" para que ele responda, mostrando se ficou ou não satisfeito. Veja se há pausas entre as ações de cada um. Por exemplo, após algum movimento, como choro ou vocalizações do bebê, a mãe muda a posição dele no colo, oferece a chupeta, o peito, a mamadeira ou um brinquedo, e espera a reação dele.

\section{5 - Item 5: Há trocas de olhares entre o bebê e a mãe.}

Observe se a mãe e o bebê se olham. Ou então, se durante momentos como alimentação, troca de fralda, diálogo entre mãe e bebê, um procura pelo olhar do outro, realizando trocas de olhares. Marque PRESENTE se houver trocas e olhares e AUSENTE em caso negativo.

\section{Período: de 4 a 7 meses e 29 dias}

\section{6 - A criança começa a diferenciar o dia da noite.}

Este item verifica se o bebê está começando a definir ritmos em seus hábitos de sono. É importante saber se o bebê fica a maior parte do dia acordado e se dorme durante a noite. Pode surgir no relato espontâneo da mãe ou pode ser perguntado a ela. Exemplo: "Em que horários seu bebê dorme?"; "Seu bebê dorme a noite toda?"; "Como é o sono dele durante o dia?" Marque PRESENTE se o bebê dorme a maior parte da noite e fica acordado na maior parte do dia ou marque AUSENTE caso contrário.

7 - A criança utiliza sinais diferentes para expressar suas diferentes necessidades.

Observe se o bebê é capaz de diferenciar objetos, pessoas ou situações, manifestando-se de maneira distinta para cada uma delas. Em geral, os bebês se expressam por meio de sílabas ou gestos diversos. Exemplo: Ao pedir água, o bebê diz "GA-GA" ou aponta para a mamadeira, ao passo que para solicitar a mãe, fala "MA-MA" ou tenta suspender o corpo para ganhar colo. 


\section{8 - A criança solicita a mãe ou cuidador e faz um intervalo para aguardar sua} resposta.

É importante ficar atento se ao chamar a mãe, chorando, emitindo sons ou gesticulando, o bebê dá um tempo para que ela responda. Esse intervalo no chamado demonstra que ele está seguro de que a mãe irá responder. Se a solicitação do bebê inclui pausas ou alterações em sua intensidade, marque PRESENTE. Se for contínua, sem pausas, marque AUSENTE.

9 - A mãe ou cuidador fala com a criança dirigindo-lhe pequenas frases.

Observe se a mãe se dirige à criança falando, perguntando, contando o que está acontecendo, dizendo algo para acalmá-la ou chamando a sua atenção. Por exemplo: "Você está ficando muito levado, né?; "O que o nenê quer?"; "Vamos, Paulo. A consulta já acabou".

10 - A criança reage (olhando, prestando atenção, sorrindo ou balbuciando) quando a mãe ou outra pessoa está se dirigindo a ela.

Preste atenção às reações do bebê quando a mãe ou outras pessoas se dirigem a ele. Geralmente, o bebê responde com olhares, vocalizações, sorrisos ou outras manifestações. Se essas reações ocorrerem, marque PRESENTE. Do contrário, marque AUSENTE.

11 - A criança procura ativamente o olhar da mãe ou cuidador.

É importante prestar atenção se o bebê busca o olhar da mãe em diferentes situações, como ao sorrir, vocalizar ou quando explora o ambiente ao seu redor. A busca deste olhar é a tentativa do bebê se certificar da presença do cuidador.

12 - A mãe ou cuidador dá suporte às iniciativas da criança sem poupar-lhe o esforço. Verifique se a mãe dá atenção aos interesses do bebê e se, ao perceber a intenção dele em fazer algo que não consegue sozinho, ela o ajuda sem fazer por ele. Exemplos: se o bebê está sentado e balança seu corpo demonstrando querer se levantar, a mãe o segura, dando-o apoio para que fique em pé; se ele quer pegar alguma coisa fora do seu alcance, ela aproxima o objeto dele, mas deixa que ele pegue sozinho. Caso a mãe ajude o bebê, marque PRESENTE. Marque AUSENTE se a mãe não o ajuda ou se faz por ele sem que ele precise fazer qualquer esforço para ter o que deseja.

13 - A criança pede a ajuda de outra pessoa sem ficar passiva.

Observe se o bebê é ativo, movimentando-se e explorando o lugar onde está. Verifique se o bebê faz esforço além da ajuda que recebe da mãe ou de outra pessoa.Por exemplo, o bebê quer descer do colo e a mãe lhe dá sustentação para favorecer seu equilíbrio e mudança postural. Nesse caso, ele está realizando seu objetivo e a mãe, agindo como facilitadora. Caso este item não apareça espontaneamente, você pode estimular o interesse do bebê por determinado objeto, fazendo barulho com chaves ou balançando uma caneta e colocando tais objetos ao alcance dele, motivando uma resposta ativa. Marque PRESENTE se isso ocorrer. Se o bebê ficar passivo, apenas à espera da reação do cuidador, marque AUSENTE. 


\section{Período: 8 a 11 meses e 29 dias}

\section{4 - A mãe (ou outro cuidador) percebe quando a criança está querendo chamar sua atenção.}

Às vezes a criança está chorando, gritando, birrenta,demonstrando estar querendo alguma coisa (mamar, papinha, água), mas na verdade o que ela quer é a atenção e o carinho da mãe. Repare se a mãe consegue perceber isso. Exemplo: A mãe sabe que às vezes a criança chora quando pára de mamar porque ela quer continuar no colo, e não apenas por fome? Se sim, marque PRESENTE. Isso indica que a criança não faz pedidos apenas para satisfazer suas necessidades físicas e que o cuidador está atento a isso.

15 - Durante a troca de fraldas, a alimentação, banho e outros cuidados com o corpo, a criança brinca com a mãe (ou outro cuidador) e demonstra carinho por ela.

Verifique se há jogos e brincadeiras quando a mãe veste ou tira a roupa da criança. Como a criança reage no banho? Ela levanta os pés ou estende as mãos para a mãe beijar? A mãe diz que a criança é cheirosa, gostosa, e ela gosta? Se houver demonstrações de carinho, marque PRESENTE.

16 - A criança demonstra quando gosta ou não de alguma coisa.

É fácil perceber quando a criança gosta de alguma coisa e quando ela não gosta? Observe se ela é capaz de manifestar prazer (aceitação) e desprazer (rejeição) em situações do dia-a-dia dela. A criança pode expressar seus gostos de diversas maneiras: chorando, fazendo birra, sorrindo, batendo palmas, querendo pegar um objeto. Caso não consiga observar o item, pergunte à mãe ou cuidador.

17 - Mãe e criança possuem uma linguagem que faz parte da rotina e da intimidade delas.

Nesse período é esperado que mãe e criança se entendam por meio de uma linguagem construída no dia-a-dia dos cuidados. Observe ou pergunte se mãe e criança conseguem se comunicar de uma maneira própria, se têm palavras comuns, se reagem à fala e aos gestos uma da outra, reconhecendo-se. Por exemplo, a criança utiliza "meias palavras" com a mãe, para se fazer entender, como "none" para Danone, "apo" para água, "dodói" ou "tatai" para papai. Também é possível verificar essa forma de comunicação entre a mãe e a criança por meio de gestos compartilhados. A mãe pode entregar uma colher à criança para que ela espere um pouco enquanto prepara a comida. A criança entende esse gesto e se acalma, demonstrando que houve uma comunicação entre elas. Caso esse tipo de entendimento entre criança e cuidador ocorra, marque PRESENTE.

18 - A criança estranha pessoas que ela não conhece.

Procure observar se a criança chora, vira a cabeça, fica tímida, tenta se esconder quando alguém que ela não conhece se aproxima. Se não conseguir observar essas reações, pergunte a mãe ou cuidador como a criança costuma agir na presença de pessoas estranhas e em ambientes que ela não conhece.

19 - A criança possui objetos preferidos (paninho, ursinho).

Observe ou pergunte ao cuidador se a criança costuma carregar algum brinquedo preferido; se tem um ursinho de pelúcia, "paninho" ou outro objeto que ela goste de segurar, especialmente quando vai dormir ou quando está sem a mãe. Anote PRESENTE se a criança tem um objeto preferido. 
20 - A criança faz gracinhas (caretas, biquinho, pisca, bate palminhas) para chamar a atenção.

Verifique se a criança faz "gracinhas" (tais como franzir o nariz, piscar, fazer biquinho, bater palminhas, entre outras), buscando ser olhada e, assim, chamando a atenção dos outros. Quando está presente, este item demonstra que a criança está brincando, se exibindo e interagindo com quem cuida dela. Caso isso não ocorra espontaneamente, você pode tentar provocar a criança fazendo tais gestos, para ver se ela imita.

21 - A criança busca o olhar de aprovação do adulto.

Observe se a criança olha para a mãe buscando sua aprovação quando está em uma situação nova, quando quer algo ou quer saber se pode ou não pode realizar uma ação. Exemplo: em uma avaliação, a criança se estende para pegar a fita métrica que está em cima da mesa ao mesmo tempo em que olha para a mãe, pedindo a confirmação dela. Ou então, em casa, a criança ameaça colocar a mão na tomada, mas antes disso olha para a mãe ou cuidador. Se a criança age dessa maneira, marque PRESENTE.

22 - A criança aceita os alimentos picados ou inteiros (frutas, pedacinhos de carne, batata e outros) e não apenas os líquidos e papinhas.

Como é a alimentação da criança? Ela aceitou bem ou está aceitando a passagem do aleitamento materno para a inclusão de alimentos variados? Observar ou perguntar sobre o preparo da refeição e como é dado à criança. Checar se usa liquidificador ou não. Perguntar que tipo de alimento é dado e se é líquido ou em pedaços. Caso esteja comendo frutas, pedacinhos de carne, batata ou outros alimentos, marque PRESENTE. Se toma apenas leite, sopa ou alimentos batidos, marque AUSENTE.

QDC 3 - A criança pega um objeto ou brinquedo da mão da pessoa que lhe oferece.

A criança fica interessada quando alguém apresenta um objeto a ela? Ela tenta pegá-lo diretamente da mão dessa pessoa? Ofereça um objeto que a criança ainda não conhece tão bem (caneta, chave, palito) e observe se ela pega ou não. Caso ela não pegue, marque AUSENTE.

QDC 6 - A postura e os gestos da criança parecem adequados (ela consegue sustentar o corpo sem ficar dura demais).

Observe como a criança anda, senta ou engatinha e como ela se acomoda no colo da mãe. Ela fica mole ou dura demais? Para verificar o item, você pode pegar a criança no colo ou colocá-la em pé, apoiada em uma cadeira, para ver como ela se sustenta. Se a criança demonstra ter postura e gestos adequados, marque PRESENTE. Se você perceber alguma dificuldade como rigidez ou o corpo muito mole, marque AUSENTE.

\section{Período: 12 a 17 meses e 29 dias}

\section{3 - A mãe alterna momentos de dedicação à criança com outros interesses.}

Nessa faixa, buscamos saber se a mãe realiza outras atividades além de cuidardo bebê. Se elaconsegue se organizarpara cuidardo bebê, cuidar da casa, dar atenção ao parceiro, estudar, trabalhar, etc., marque PRESENTE. Se a mãe só se ocupa de cuidar da criança, marque AUSENTE. 
24 - A criança suporta bem as breves ausências da mãe e reage às ausências prolongadas.

Pergunte para a mãe aonde vai e por quanto tempo quando ela se ausenta rapidamente. Em seguida, pergunte como a criança reage: chora ou fica tranquila?

Pergunte para a mãe aonde vai e por quanto tempo quando ela se ausenta longamente. Em seguida, pergunte como a criança reage: chora ou fica tranquila?

Se a criança fica tranquila nas ausências curtas, mas sente as prolongadas, marque PRESENTE. Se a criança não aguenta as curtas ou fica indiferente às longas, marque AUSENTE.

25 - A mãe oferece brinquedos como alternativas para o interesse da criança pelo corpo materno.

Esse indicador investiga se a mãe põe limites quando a criança quer ficar tocando seu corpo (pondo a mão dentro de sua blusa, pegando seu cabelo repetidas vezes). Se a mãe demonstra desagrado e propõe alguma alternativa, como oferecer objetos de interesse da criança (seus brincos, colar, pulseira, relógio), marque PRESENTE. Se a mãe deixa a criança ficar pegando partes do seu corpo (da mãe) sem colocar limites, marque AUSENTE.

26 - A mãe não se sente mais obrigada a satisfazer tudo que a criança pede.

Observe se a mãe percebe e entende os pedidos da criança, sem se sentir obrigada a fazer todas as suas vontades.Quando a mãe impõe limites à criança, ela pode ter reações de confronto, como mexer em objetos de outras pessoas, em objetos perigosos ou que quebrem com facilidade. Se a mãe consegue sustentar a proibição, dizendo: "não faça isso", "aí não pode", "isso não é seu", marque PRESENTE. Se a mãe sente que precisa fazer tudo o que a criança pede, marque AUSENTE.

\section{7 - A criança olha com curiosidade para o que interessa à mãe.}

Se a criança está atenta a situações e objetos de interesse da mãe, acompanhandoquando ela está falando com alguém, quando mexe em sua bolsa, quando está fazendo os serviços de casa, demonstrando querer participar, marque PRESENTE.

\section{8 - A criança gosta de brincar com objetos usados pela mãe e pelo pai.}

Se isso não for observado ou dito espontaneamente, pergunte à mãe se a criança se interessa pelos objetos da casa, como chaves, roupas, sapatos, telefone, panelas, etc. Sea criança não se satisfaz apenas com brinquedos, pois já reconhece quais são os objetos que despertam o interesse dos adultos e passa a querer o que os outros querem, marque PRESENTE. Se ela não liga para os objetos dos pais, marque AUSENTE.

29 - A mãe começa a pedir à criança que nomeie o que deseja, não se contentando apenas com gestos.

Observe se quando a criança quer algo, ela chora, aponta ou grita ou se utiliza a fala, acompanhada ou não de gestos. Se a mãe a incentiva a dizer o que está querendo, marque PRESENTE?Se a mãe vai logo "adivinhando" o que ela quer, ou se oferece 
objetos sem pedir que a criança fale, marque AUSENTE. Caso não apareça espontaneamente, isto também pode ser perguntado.

\section{0 - Os pais colocam pequenas regras de comportamento para a criança.}

Nessa fase, é esperado que apareçam ordens simples e proibições dirigidas à criança. Se os paiscomeçam a dizer como ela deve se comportar em algumas situações, marque PRESENTE.Se a criança pode fazer tudo o que quer e os pais permitem, marque AUSENTE.

\section{1 - A criança diferencia objetos maternos, paternos e próprios.}

Se a criança se interessou por algum objeto de outra pessoa, pode ser perguntado a ela: "de quem é?" - e observar a resposta. Esse indicador também pode ser obtido em conversa com os pais. Se a criança entrega os objetos aos seus donos (mãe, pai, profissional de saúde) ou se diz de quem é, apontando ou olhando para a pessoa (papá, mamá, nenê), marque PRESENTE. Se elademonstra não saber de quem são os objetos, marque AUSENTE. 


\section{APÊNDICE B - TERMO DE CONSENTIMENTO LIVRE E ESCLARECIDO}

\section{$\underline{\text { Termo de consentimento livre e esclarecido }}$}

Título da pesquisa : Detecção precoce de riscos para transtornos do espectro de autismo com Indicadores Clínicos de Risco para o Desenvolvimento Infantil e intervenção precoce: capacitação de enfermeiros para o trabalho em unidades básicas de saúde.

Pesquisador responsável: Prof. Dr. Rogério Lerner (IPUSP)

Pesquisadoras que realizarão esta etapa da pesquisa: Andrea Bianchini Tocchio (IPUSP) e Ana Silvia de Morais (IP-USP).

Esta pesquisa acompanhará seu trabalho na avaliação da relação entre bebês e pais durante encontros de puericultura. Aprofundando o conhecimento sobre a formação de pessoas envolvidas em atendimentos de bebês e seus pais, pode-se divulgar tal conhecimento para beneficiar mais pessoas e, assim, um número maior de bebês e pais. Para isso, propomos um curso de difusão gratuito no Instituto de Psicologia da Universidade de São Paulo (IPUSP) sobre Indicadores Clínicos de Risco para o Desenvolvimento Infantil (IRDI). Sua colaboração será de grande auxílio para nós. Ela não envolve nenhum risco para os envolvidos. É necessário que participe de quatro encontros de quatro horas cada, durante o ano de 2011, preencha as fichas de acompanhamento do curso, aplique o protocolo IRDI e discuta os casos com o pesquisador que estará à disposição semanalmente nos locais de aplicação. Garantimos que todos os dados serão mantidos em sigilo e somente servirão para este estudo. Os resultados da pesquisa serão apresentados em publicações e eventos científicos sem identificação dos participantes. Você tem total liberdade de deixar de participar da pesquisa quando considerar necessário, sem sofrer qualquer dano ou prejuízo por parte dos pesquisadores ou dos serviços de saúde. Desde já, colocamo-nos à disposição para esclarecer qualquer dúvida. Para isso, pode utilizar o telefone (11) 3091-4185, procurando pelo pesquisador responsável, Prof. Dr. Rogério Lerner.

$\mathrm{Eu}$, declaro ter entendido o que me foi explicado, consinto em participar do presente Projeto de Pesquisa.

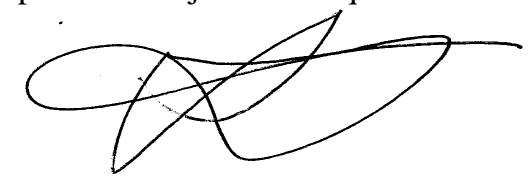

Assinatura do participante

Assinatura do pesquisador

Prof. Dr. Rogério Lerner (IP-USP)

São Paulo, de de 20

Para maiores esclarecimentos, procurar pelo Prof. Dr. Rogério Lerner(Av. Prof. Mello Moraes, 1721, Bloco A, sala 158, Cidade Universitária - São Paulo, SP- fone (11) 3091-4185).

Nome do participante:

RG:

Sexo:

Data de nascimento:

Endereço:

Telefones: ; ( $)$ 


\section{APÊNDICE C - FICHA DE AVALIAÇÃO DO CURSO DE FORMAÇÃO PARA UTILIZAÇÃO DO IRDI}

Caro profissional de saúde, favor preencher essa ficha de avaliação do curso de formação do IRDI, mesmo que você não esteja mais participando da proposta. Caso não vá ao terceiro encontro do curso no dia 05/08/11, entregue a um colega que irá participar da próxima etapa. Agradecemos sua colaboração.

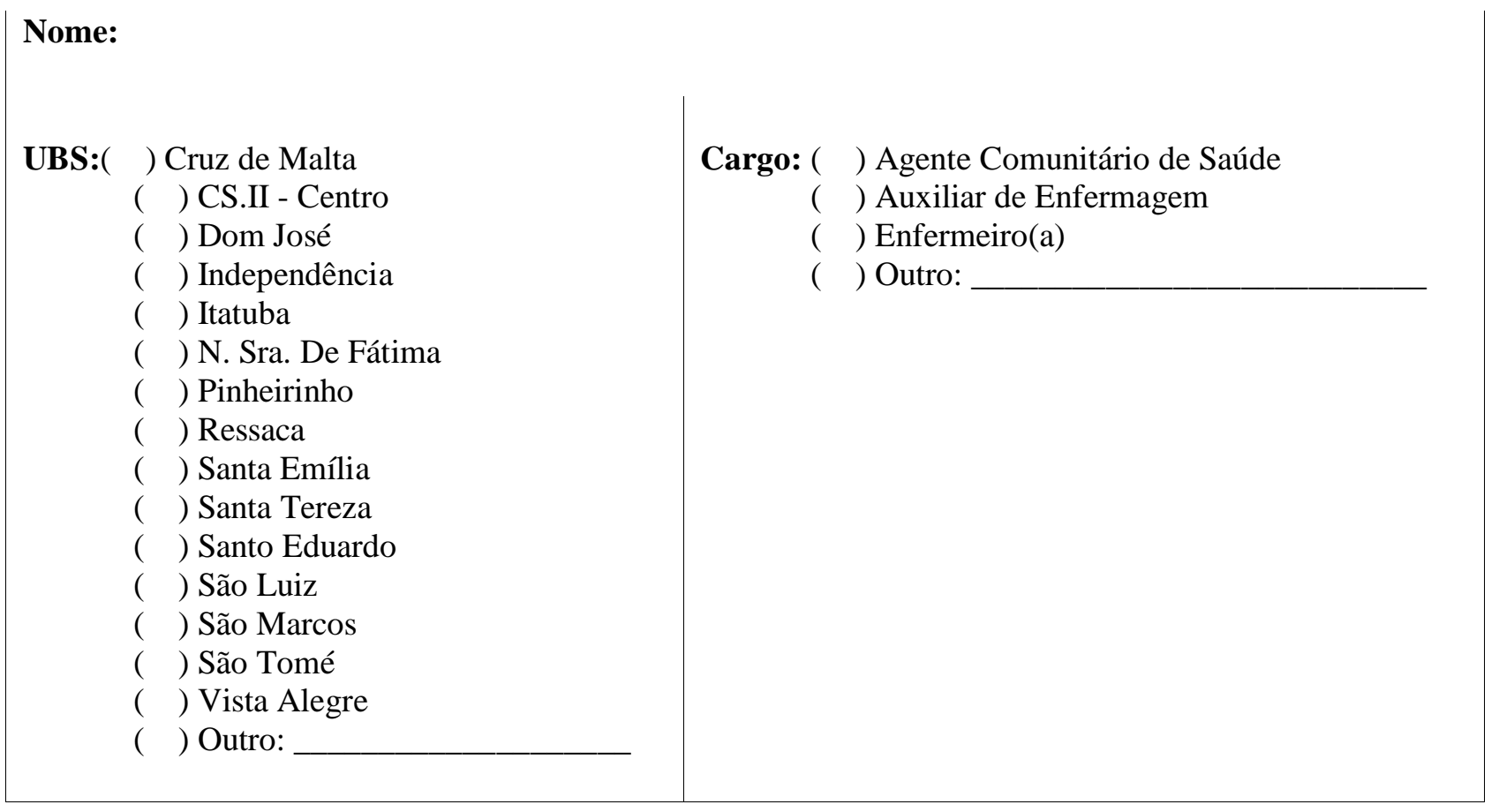

1. Você está participando do curso de formação para utilização do protocolo IRDI - Indicadores de Risco para o Desenvolvimento Infantil?

\section{( )Sim \\ ( ) Não}

Se não está participando, por quê?

2. Lembrando que a aplicação do IRDI não é obrigatória, você está aplicando o protocolo?

\section{( ) Sim \\ ( ) Não}




\section{FICHA DE AVALIAÇÃO DO CURSO DE FORMAÇÃO PARA UTILIZAÇÃO DO IRDI}

Assinale com um $\mathbf{X}$ as afirmações abaixo para justificar sua resposta (marque quantos itens quiser).

\begin{tabular}{|l|l|}
\hline Sim, estou aplicando porque: & Não estou aplicando porque: \\
\hline $\begin{array}{l}\text { ( ) Me sinto obrigado. } \\
\begin{array}{l}\text { ( ) Acho que posso contribuir com a detecção de } \\
\text { problemas graves na infância. }\end{array}\end{array}$ & $\begin{array}{l}\text { ( ) A proposta não me interessa. } \\
\text { do meu trabalho; é tarefa de outro profissional. }\end{array}$ \\
\hline $\begin{array}{l}\text { ( ) Quero aprender mais sobre o assunto. } \\
\text { ( ) Tenho receio de perceber algo errado com o } \\
\text { bebê e não saber o que fazer. }\end{array}$ \\
\hline ( ) Acho que faz parte da minha função. & ( ) Não tenho tempo. \\
\hline ( ) Outros: & ( ) Outros: \\
& \\
\hline
\end{tabular}

3. Em relação à aplicação do IRDI,assinale com um Xo grau de dificuldade que você tem ou teve em cada um dos aspectos abaixo.

\begin{tabular}{|l|l|l|l|l|}
\multicolumn{1}{|c|}{ Aspectos } & $\begin{array}{c}\text { Nenhuma } \\
\text { Dificuldade }\end{array}$ & $\begin{array}{c}\text { Pouca } \\
\text { Dificuldade }\end{array}$ & $\begin{array}{c}\text { Média } \\
\text { Dificuldade }\end{array}$ & $\begin{array}{c}\text { Muita } \\
\text { Dificuldade }\end{array}$ \\
\hline $\begin{array}{l}\text { Entendimento das instruções dadas no } \\
\text { curso. }\end{array}$ & & & \\
$\begin{array}{l}\text { Entendimento dos itens do protocolo. } \\
\text { Conciliar a aplicação do protocolo e o } \\
\text { trabalho na unidade. }\end{array}$ & & & \\
\hline $\begin{array}{l}\text { Ter apoio de superiores e outros } \\
\text { funcionários. }\end{array}$ & & & \\
\hline $\begin{array}{l}\text { Falar da proposta com as mães ou } \\
\text { cuidadores. } \\
\text { Acompanhar as famílias e os bebês } \\
\text { durante o processo de aplicação (18 } \\
\text { meses). }\end{array}$ & & & & \\
\hline Outros: & & & & \\
& & & \\
\end{tabular}




\section{FICHA DE AVALIAÇÃO DO CURSO DE FORMAÇÃO PARA UTILIZAÇÃO DO IRDI}

4. Este curso influenciou ou tem influenciado o seu trabalho? Como?

5. Quais os itens do IRDI você se lembra de cabeça?

Favor entregar essa ficha nopróximo encontro de formação do IRDI que será no Auditório do Colégio Valdelice, no dia 05/08/11, das 8 h às $12 \mathrm{~h}$.

Muito Obrigado! 


\section{APÊNDICE D - PRIMEIRA FICHA DE ACOMPANHAMENTO DO CURSO DE FORMAÇÃO PARA UTILIZAÇÃO DO IRDI}

\begin{tabular}{|l|l|l|l|}
\hline Nome: & Sexo: & \\
\hline Endereço: & Telefone: \\
\hline $\begin{array}{l}\text { Até que ano você estudou? Por exemplo: segundo ano do primário; } \\
\text { terceiro ano do ginásio; segundo ano colegial; ensino superior } \\
\text { completo: }\end{array}$ & Profissão: \\
\hline \begin{tabular}{l} 
Instituição: \\
\hline Há quanto tempo trabalha com bebês?
\end{tabular} & \multicolumn{2}{|l|}{} \\
\hline $\begin{array}{l}\text { Já utilizou algum instrumento ou material de apoio para } \\
\text { avaliação de bebês? } \\
\text { ( ) Sim ( ) Não }\end{array}$ & Quais? \\
\hline
\end{tabular}

Responda brevemente à seguinte questão:

Ao avaliar um bebê de até quatro meses, o que se deve buscar saber? Como isso pode ser feito? 


\section{PRIMEIRA FICHA DE ACOMPANHAMENTO DO CURSO DE FORMAÇÃO PARA UTILIZAÇÃO DO IRDI}

\begin{tabular}{|l|l|l|}
\hline Nome: & Data de nascimento: & Sexo: \\
& &
\end{tabular}

Responda cada questão abaixo, assinalando apenas uma das opções de acordo com o seguinte:

1. Concordo fortemente

2. Concordo

3. Discordo

4. Discordo fortemente

A. No meu trabalho, quando estou com um bebê, levo em conta como ele interage com as pessoas ao seu redor.

1. Concordo fortemente

2. Concordo

3. Discordo

4. Discordo fortemente

B. Se o bebê quase nunca tenta olhar para a mãe, mesmo se ela chamar sua atenção, ele pode estar com alguma dificuldade de desenvolvimento.

1. Concordo fortemente

2. Concordo

3. Discordo

4. Discordo fortemente

C. É fundamental para o desenvolvimento do bebê que a mãe o ajude tentando entender o que ele quer quando chora ou grita.

1. Concordo fortemente

2. Concordo

3. Discordo

4. Discordo fortemente 


\section{PRIMEIRA FICHA DE ACOMPANHAMENTO DO CURSO DE FORMAÇÃO PARA UTILIZAÇÃO DO IRDI}

D. Para o desenvolvimento do bebê, tanto faz se a mãe fala com ele de maneira especialmente carinhosa ou não.

1. Concordo fortemente

2. Concordo

3. Discordo

4. Discordo fortemente

E. A saúde orgânica do bebê é suficiente para seu desenvolvimento como ser humano.

1. Concordo fortemente

2. Concordo

3. Discordo

4. Discordo fortemente 
APÊNDICE E - SEGUNDA FICHA DE ACOMPANHAMENTO DO CURSO DE FORMAÇÃO PARA UTILIZAÇÃO DO IRDI

Nome:

UBS:

Cargo:

Responda brevemente à seguinte questão:

Em sua prática com bebês de até oito meses, a que você procura estar atento? De que maneira? 


\section{SEGUNDA FICHA DE ACOMPANHAMENTO DO CURSO DE FORMAÇÃO PARA UTILIZAÇÃO DO IRDI}

\section{Concordo fortemente \\ 2. Concordo \\ 3. Discordo \\ 4. Discordo fortemente}

Respondaas seguintes questões, assinalando apenas uma das opções abaixo:

A. Ao acompanhar o desenvolvimento de um bebê, observo se a mãe ou cuidador fala com ele, perguntando ou contando o que está acontecendo, bem como as reações do bebê a essa conversa.

1. Concordo fortemente

2. Concordo

3. Discordo

4. Discordo fortemente

B. Para o desenvolvimento do bebê, tanto faz se a mãe fala com ele de maneira especialmente carinhosa ou não.

1. Concordo fortemente

2. Concordo

3. Discordo

4. Discordo fortemente

C. Em relação ao desenvolvimento de um bebê de até oito meses, não importa se ele dorme mais de dia do que de noite.

1. Concordo fortemente

2. Concordo

3. Discordo

4. Discordo fortemente 
SEGUNDA FICHA DE ACOMPANHAMENTO DO CURSO DE FORMAÇÃO PARA UTILIZAÇÃO DO IRDI

Nome:

D. É importante prestar atenção se o bebê é ativo, pedindo ajuda da mãe ou de outra pessoa quando precisa e se, ao chorar, gritar ou resmungar, aguarda um pouco pela resposta de quem ele chamou.

1. Concordo fortemente

2. Concordo

3. Discordo

4. Discordo fortemente

E. É um sinal de bom desenvolvimento quando o bebê utiliza vocalizações ou gestos diversos para se expressar em diferentes ocasiões.
1. Concordo fortemente
2. Concordo
3. Discordo
4. Discordo fortemente

F. A saúde orgânica do bebê é suficiente para seu desenvolvimento como ser humano.

1. Concordo fortemente

2. Concordo

3. Discordo

4. Discordo fortemente 


\section{APÊNDICE F - QUARTA FICHA DE ACOMPANHAMENTO DO CURSO DE FORMAÇÃO PARA UTILIZAÇÃO DO IRDI}

\begin{tabular}{|c|c|c|c|}
\hline \multicolumn{4}{|c|}{ Nome: } \\
\hline UBS: & $\begin{array}{l}\text { ( ) Cruz de Malta } \\
\text { ( ) CS.II - Centro } \\
\text { ( ) Dom José } \\
\text { ( ) Independência } \\
\text { ( ) N. Sra. De Fátima } \\
\text { ( ) Pinheirinho } \\
\text { ( ) Santo Eduardo } \\
\text { ( ) São Marcos }\end{array}$ & $\begin{array}{l}\text { ( ) Santa Emília } \\
\text { ( ) Vista Alegre } \\
\text { ( ) São Tomé } \\
\text { ( ) Itatuba } \\
\text { ( ) Ressaca } \\
\text { ( ) Santa Tereza } \\
\text { ( ) São Luiz } \\
\text { Outro: }\end{array}$ & $\begin{array}{l}\text { Cargo: } \\
\begin{array}{l}\text { ( ) A C S } \\
\text { ( ) Auxiliar de Enf. } \\
\text { ( ) Enfermeiro(a) }\end{array}\end{array}$ \\
\hline
\end{tabular}

\section{Responda brevemente à seguinte questão:}

1) Em sua prática com bebês de até dezoito meses, a que você procura estar atento? De que maneira? 


\section{QUARTA FICHA DE ACOMPANHAMENTO DO CURSO DE FORMAÇÃO PARA UTILIZAÇÃO DO IRDI}

2) Após este último encontro de formação e das monitorias da quarta faixa, você pretende continuar a utilizar o IRDI em sua prática?

( ) Sim ( ) Não

Justifique: por que sim ou por que não? 


\section{APÊNDICE G - QUINTA FICHA DE ACOMPANHAMENTO DO CURSO DE FORMAÇÃO PARA UTILIZAÇÃO DO IRDI}

UBS:

Cargo:( ) Agente Comunitário de Saúde ( ) Auxiliar de Enfermagem

( ) Enfermeiro(a)( ) Outro:

1. Em sua prática com bebês, a que você procura estar atento? Descreva como eresponda de acordo com a idade do bebê:

- De até 4 meses

- De até 8 meses

- De até 12 meses 
- De até 18 meses

2. Você passou pelos encontros de formação para uso dos IRDIs?
( ) Não. ( ) Sim, fui a 1 encontro
( ) Sim, fui a 3 encontros
( ) Sim, fui a 2 encontros
( ) Sim, fui a 4 encontros

3. No seu trabalho, você foi acompanhado ou teve reuniões com alguma das monitoras (Ana Silvia ou Andrea)?

4. Quais são os indicadores do protocolo IRDI que você se lembra de cabeça?

5. Você usa o IRDI de alguma maneira no seu trabalho?

( ) Sim. Como?

( ) Não

6. Se você teve dificuldades com o uso do IRDI, comente-as abaixo:

7. Quais são suas sugestões para a incorporação do IRDI na rotina? 
Anexos 


\section{ANEXO A -PROTOCOLO IRDI - FOLHA DE ROSTO}

\begin{tabular}{|c|c|}
\hline UBS onde a criança é atendida: & $\begin{array}{l}\text { No. do prontuário no serviço: } \\
\text { No. na pesquisa: }\end{array}$ \\
\hline Nome completo da criança: & $\begin{array}{l}\text { Data de nascimento: } \\
\text { Sexo: }(\text { ) masculino }(\text { feminino }\end{array}$ \\
\hline Nomes completos dos pais: & $\begin{array}{l}\text { Telefones dos pais: } \\
\text { Endereço completo (com CEP): }\end{array}$ \\
\hline Idade gestacional: ___ semanas & Posição da criança na família: \\
\hline Peso ao nascer: $\quad \mathrm{g}$ & APGAR 5: \\
\hline Número de consultas em pré-natal: & $\begin{array}{l}\text { Duração da amamentação exclusiva: } \\
\text { meses }\end{array}$ \\
\hline $\begin{array}{l}\text { Época do desmame: } \\
\text { meses }\end{array}$ & \\
\hline $\begin{array}{l}\text { Idade materna: } \\
\text { anos }\end{array}$ & Escolaridade Materna: \\
\hline
\end{tabular}

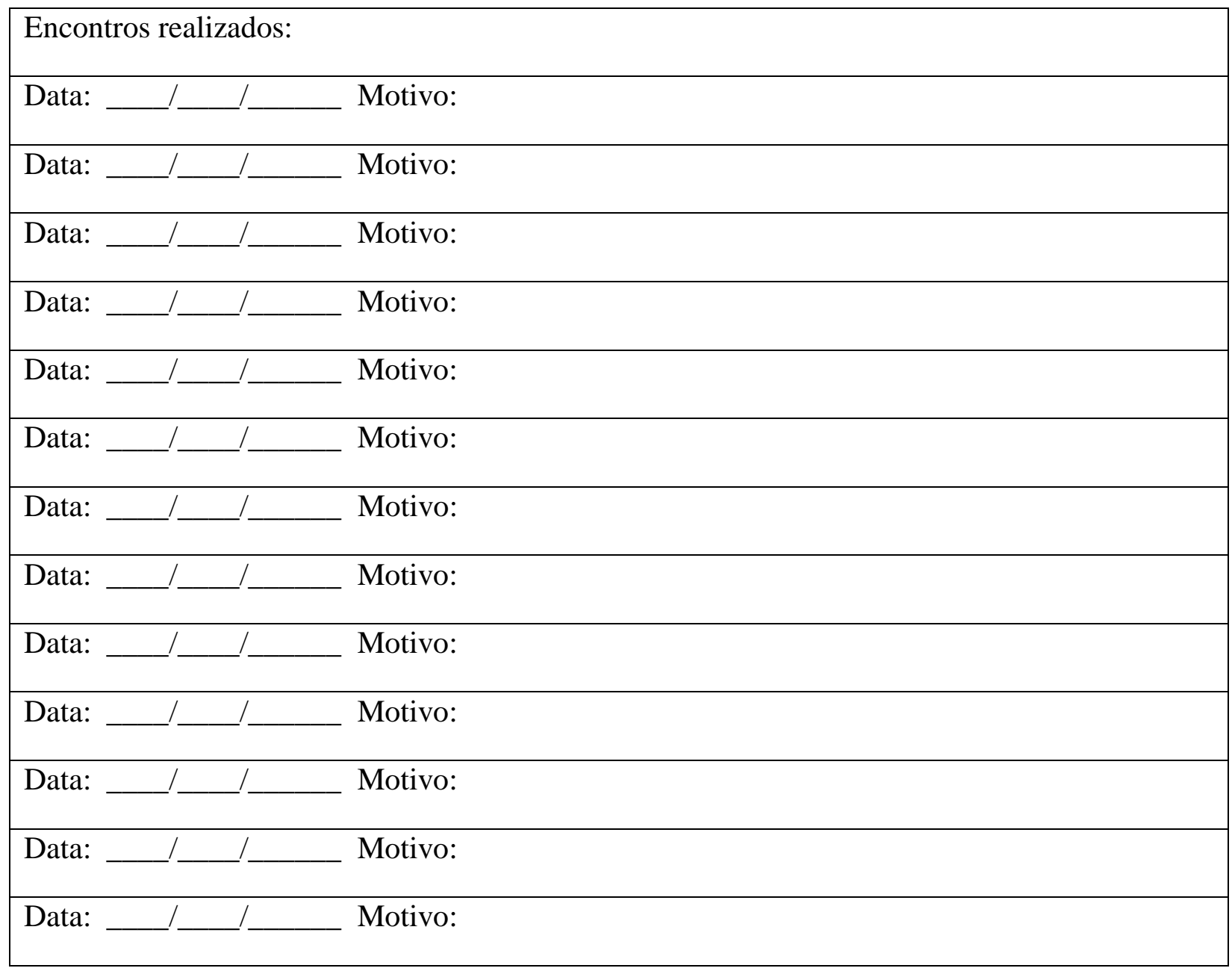




\section{PROTOCOLO IRDI - $1^{\text {a }}$ FICHA DE APLICAÇÃO}

Nome da criança:

Data de nasc.:

$\mathrm{N}^{\mathrm{o}}$ na pesquisa:

UBS:

$\mathrm{N}^{\mathrm{o}}$ do prontuário:

Profissional que aplicou:

Data da aplicação:

Nome do cuidador que acompanhou a criança:

Pai ( ) Mãe ( ) Outro ( ):

\section{Legenda:}

$\mathbf{P}=$ Presente

$\mathbf{A}=$ Ausente

$\mathbf{N V}=$ Não verificado

\begin{tabular}{|c|c|c|}
\hline Indicadores de 0 a 3 meses e 29 dias: & $\begin{array}{c}\text { Anotar } P, A, \text { ou NV } \\
\text { para cada item }\end{array}$ & Observações: \\
\hline $\begin{array}{l}\text { 1- Quando a criança chora ou grita, a mãe sabe o } \\
\text { que ela quer. }\end{array}$ & & \\
\hline $\begin{array}{l}\text { 2- A mãe fala com a criança num estilo } \\
\text { particularmente dirigido a ela (manhês). }\end{array}$ & & \\
\hline 3- A criança reage ao manhês. & & \\
\hline $\begin{array}{l}\text { 4- A mãe propõe algo à criança e aguarda a sua } \\
\text { reação. }\end{array}$ & & \\
\hline 5- Há trocas de olhares entre a criança e a mãe. & & \\
\hline
\end{tabular}




\section{PROTOCOLO IRDI - $2^{\mathrm{a}}$ FICHA DE APLICAÇÃO}

Nome da criança:

Data de nasc.: 1 $\mathrm{N}^{\mathrm{o}}$ na pesquisa:

UBS: $\mathrm{N}^{\mathrm{o}}$ do prontuário:

Profissional que aplicou: Data da aplicação:

Nome do cuidador que acompanhou a criança:

Pai ( ) Mãe ( ) Outro ( ):

\section{Legenda:}

$\mathbf{P}=$ Presente

$\mathbf{A}=$ Ausente

$\mathbf{N V}=$ Não verificado

\begin{tabular}{|c|c|c|}
\hline Indicadores de 4 a 7 meses e 29 dias: & $\begin{array}{l}\text { Anotar } \mathbf{P}, \mathbf{A}, \text { ou } \mathrm{NV} \\
\text { para cada item }\end{array}$ & Observações: \\
\hline $\begin{array}{l}\text { 6- A criança começa a diferenciar o dia da } \\
\text { noite. }\end{array}$ & & \\
\hline $\begin{array}{l}\text { 7- A criança utiliza sinais diferentes para } \\
\text { expressar suas diferentes necessidades. }\end{array}$ & & \\
\hline $\begin{array}{l}\text { 8- A criança solicita a mãe ou cuidador e } \\
\text { faz um intervalo para aguardar sua } \\
\text { resposta. }\end{array}$ & & \\
\hline $\begin{array}{l}\text { 9- A mãe ou cuidador fala com a criança } \\
\text { dirigindo-lhe pequenas frases. }\end{array}$ & & \\
\hline $\begin{array}{l}\text { 10- A criança reage (olhando, prestando } \\
\text { atenção, sorrindo ou balbuciando) } \\
\text { quando a mãe ou outra pessoa está se } \\
\text { dirigindo a ela. }\end{array}$ & & \\
\hline $\begin{array}{l}\text { 11- A criança procura ativamente o olhar da } \\
\text { mãe ou cuidador. }\end{array}$ & & \\
\hline $\begin{array}{l}\text { 12- A mãe ou cuidador dá suporte às } \\
\text { iniciativas da criança sem poupar-lhe o } \\
\text { esforço. }\end{array}$ & & \\
\hline $\begin{array}{l}\text { 13- A criança pede a ajuda de outra pessoa } \\
\text { sem ficar passiva. }\end{array}$ & & \\
\hline
\end{tabular}


Nome da criança:

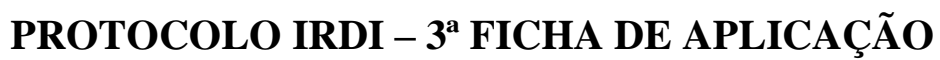

Data de nasc.:

1

$\mathrm{N}^{\mathrm{o}}$ na pesquisa:

UBS: $\mathrm{N}^{\mathrm{o}}$ do prontuário:

Profissional que aplicou: Data da aplicação:

Nome do cuidador que acompanhou a criança:

Pai ( ) Mãe ( ) Outro ( ):

\section{Legenda:}

$\mathbf{P}=$ Presente

$\mathbf{A}=$ Ausente

$\mathbf{N V}=$ Não verificado

\begin{tabular}{|c|l|l|}
\hline Indicadores de 8 a 11 meses e 29 dias: & $\begin{array}{l}\text { Anotar P, A, ou NV } \\
\text { para cada item }\end{array}$ & Observações: \\
\hline $\begin{array}{c}\text { 14- A mãe ou cuidador percebe quando a criança } \\
\text { está querendo chamar a sua atenção. }\end{array}$ & & \\
\hline $\begin{array}{c}\text { 15- Durante a troca de fraldas, a alimentação, o } \\
\text { banho e outros cuidados com o corpo, a criança } \\
\text { brinca com a mãe (ou cuidador) e demonstra } \\
\text { carinho por ela. }\end{array}$ & & \\
\hline $\begin{array}{c}\text { 16- A criança demonstra quando gosta ou não gosta } \\
\text { de alguma coisa. }\end{array}$ & & \\
\hline $\begin{array}{c}\text { 17- Mãe e criança possuem uma linguagem que faz } \\
\text { parte da rotina e da intimidade delas. }\end{array}$ & & \\
\hline $\begin{array}{c}\text { 18- A criança estranha pessoas que ela não } \\
\text { conhece. }\end{array}$ & & \\
\hline $\begin{array}{c}\text { 19- A criança possui objetos preferidos (paninho, } \\
\text { ursinho). }\end{array}$ & & \\
\hline $\begin{array}{c}\text { 20- A criança faz gracinhas (caretas, biquinho, } \\
\text { pisca, bate palminhas) para chamar atenção. }\end{array}$ & & \\
\hline $\begin{array}{l}\text { 21- A criança busca o olhar de aprovação do adulto. } \\
\text { 22- A criança aceita os alimentos picados ou } \\
\text { inteiros (frutas, pedacinhos de carne, batata e } \\
\text { outros) e não apenas os líquidos e papinhas. }\end{array}$ & & \\
\hline $\begin{array}{l}\text { QDC 3* -A criança pega um objeto ou brinquedo da } \\
\text { mão da pessoa que lhe oferece. }\end{array}$ & \\
\hline $\begin{array}{l}\text { QDC 6 -A postura e os gestos da criança parecem } \\
\text { adequados (ela consegue sustentar o corpo sem ficar } \\
\text { dura demais). }\end{array}$ & & \\
\hline
\end{tabular}

*Os itens QDC 3 e 6 do Questionário do Desenvolvimento da Comunicação foram incluídos no protocolo,devidocapacidade discriminativa estatisticamente significativa entre as patologiasautismo, retardo mental e a normalidade. (Lerner, R. 2011) 


\section{PROTOCOLO IRDI - 4 FICHA DE APLICAÇÃO}

Nome da criança:

Data de nasc.: 1

$\mathrm{N}^{\mathrm{o}}$ na pesquisa:

UBS: $\mathrm{N}^{\mathrm{o}}$ do prontuário:

Profissional que aplicou: Data da aplicação:

Nome do cuidador que acompanhou a criança:

Pai ( ) Mãe ( ) Outro ( ):

\section{Legenda:}

$\mathbf{P}=$ Presente

$\mathbf{A}=$ Ausente

$\mathbf{N V}=$ Não verificado

\begin{tabular}{|c|l|l|}
\hline $\begin{array}{c}\text { Indicadores de 12 a 17 meses e 29 dias: } \\
\text { 23- A mãe alterna momentos de dedicação à } \\
\text { criança com outros interesses. }\end{array}$ & $\begin{array}{l}\text { Anotar P, A, ou NV para } \\
\text { cada item }\end{array}$ & Observações: \\
\hline $\begin{array}{c}\text { 24- A criança suporta bem as breves ausências da } \\
\text { mãe e reage às ausências prolongadas. }\end{array}$ & & \\
\hline $\begin{array}{c}\text { 25- A mãe oferece brinquedos como alternativas } \\
\text { para o interesse da criança pelo corpo } \\
\text { materno. }\end{array}$ & & \\
\hline $\begin{array}{c}\text { 26- A mãe não se sente mais obrigada a satisfazer } \\
\text { tudo que a criança pede. }\end{array}$ & & \\
\hline $\begin{array}{c}\text { 27- A criança olha com curiosidade para o que } \\
\text { interessa à mãe. }\end{array}$ & & \\
\hline $\begin{array}{c}\text { 28- A criança gosta de brincar com objetos } \\
\text { usados pela mãe e pelo pai. }\end{array}$ & & \\
\hline $\begin{array}{c}\text { 29- A mãe começa a pedir à criança que nomeie } \\
\text { o que deseja, não se contentando apenas com } \\
\text { gestos. }\end{array}$ & & \\
\hline $\begin{array}{c}\text { 30- Os pais colocam pequenas regras de } \\
\text { comportamento para a criança. }\end{array}$ & & \\
\hline $\begin{array}{c}\text { 31- A criança diferencia objetos maternos, } \\
\text { paternos e próprios. }\end{array}$ & & \\
\hline
\end{tabular}


ANEXO B - PROTOCOLO DE ATENDIMENTO EM ENFERMAGEM

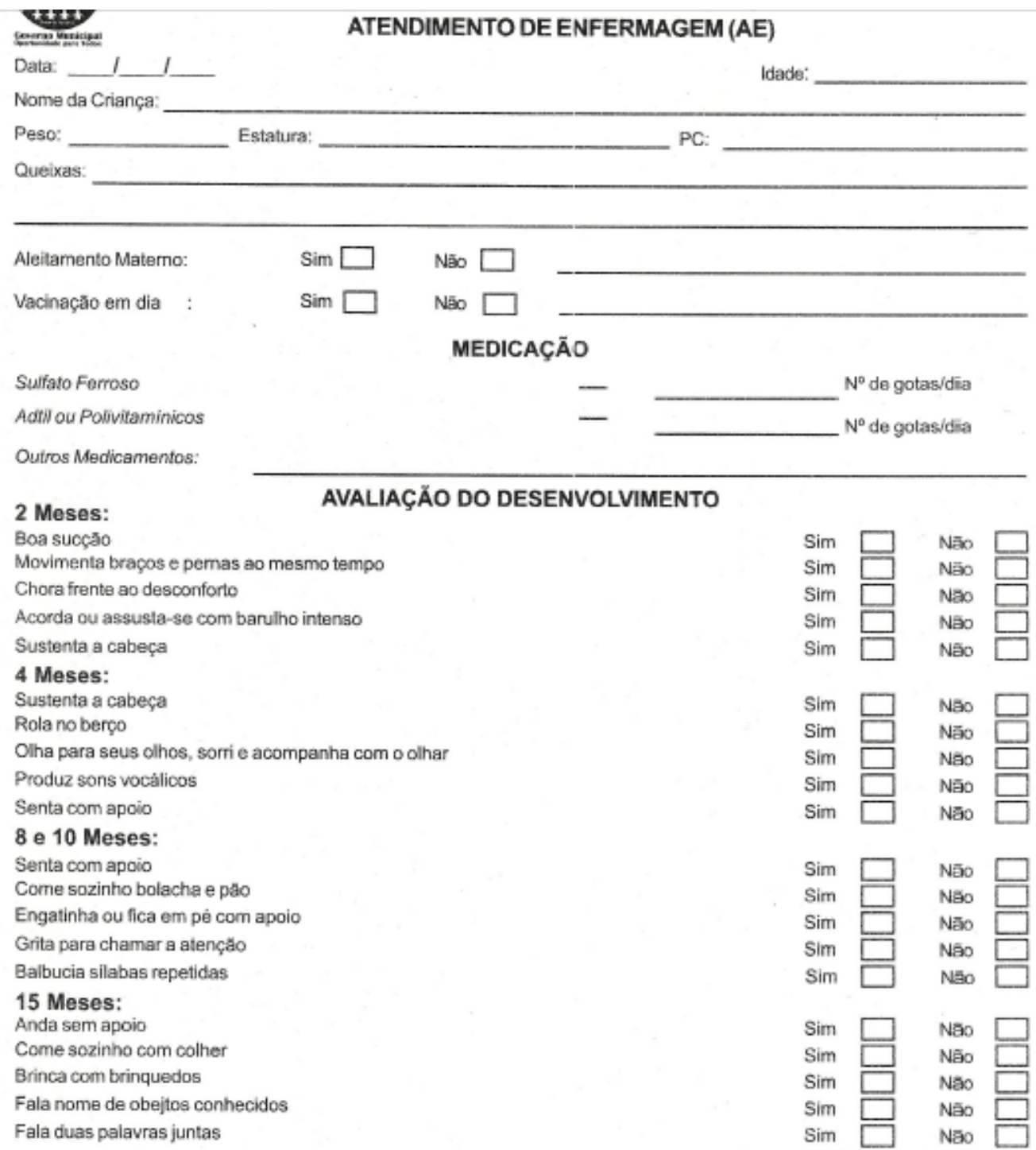

Quem cuida da criança, rotinas, frequência a creche, avaliar situaçōes de risco para negligência e maus tratos.

Conduta 